\title{
The emergence and decline of the Delaware Indian nation in western Pennsylvania and the Ohio country, 1730-1795
}

Richard S. Grimes

West Virginia University

Follow this and additional works at: https://researchrepository.wvu.edu/etd

\section{Recommended Citation}

Grimes, Richard S., "The emergence and decline of the Delaware Indian nation in western Pennsylvania and the Ohio country, 1730--1795" (2005). Graduate Theses, Dissertations, and Problem Reports. 4150. https://researchrepository.wvu.edu/etd/4150

This Dissertation is protected by copyright and/or related rights. It has been brought to you by the The Research Repository @ WVU with permission from the rights-holder(s). You are free to use this Dissertation in any way that is permitted by the copyright and related rights legislation that applies to your use. For other uses you must obtain permission from the rights-holder(s) directly, unless additional rights are indicated by a Creative Commons license in the record and/ or on the work itself. This Dissertation has been accepted for inclusion in WVU Graduate Theses, Dissertations, and Problem Reports collection by an authorized administrator of The Research Repository @ WVU.

For more information, please contact researchrepository@mail.wvu.edu. 


\title{
The Emergence and Decline of the Delaware Indian Nation in Western Pennsylvania and the Ohio Country, 1730-1795
}

\author{
Richard S. Grimes \\ Dissertation submitted to the \\ Eberly College of Arts and Sciences \\ at West Virginia University \\ in partial fulfillment of the requirements \\ for the degree of \\ Doctor of Philosophy \\ in \\ History \\ Mary Lou Lustig, Ph.D., Chair \\ Kenneth A. Fones-Wolf, Ph.D. \\ Michal A. McMahon, Ph.D. \\ James H. Merrell, Ph.D. \\ John C. Super, Ph.D. \\ Department of History \\ Morgantown, West Virginia \\ 2005
}

Keywords: Delaware Indians, Lenape Indians, Western Pennsylvania frontier, Ohio Country, Six Nations of Iroquois, John Heckewelder, David Zeisberger 


\begin{abstract}
"The Emergence and Decline of the Delaware Indian Nation in

Western Pennsylvania and the Ohio Country, 1730-1795"
\end{abstract}

\author{
Richard S. Grimes
}

Many past and current generations of historians, anthropologists, and literary writers have acknowledged the existence of a Delaware Indian nation. They, however, have failed to thoroughly understand or address the historical and cultural dynamics that contributed to both the formation and quick decline of this Indian nation. This multidisciplinary study includes the oral traditions and oratory of Delaware Indians, the observances of Moravian missionaries and colonial-revolutionary officials, and contemporary anthropological and historical sources, to construct the building of the Delaware nation during the eighteenth century.

Once decentralized and living in the Delaware River watershed, three phratries or animal tribes (Turtle, Turkey, and Wolf) of Delawares, in response to their unfair treatment at the hands of the Pennsylvania-Iroquois alliance of 1732, moved west to the Allegheny Valley of western Pennsylvania and eventually across the Ohio River into the Muskingum River valley. Western Delawares developed a sense of common cause and weathered the turmoil of imperial conflict between the French and British during the Seven Years' War in western Pennsylvania. A regional identity was greatly enhanced when western Delawares by 1765 separated themselves politically from their eastern kin who remained on the Susquehanna.

This dissertation also considers the creation of a National Council or Lupwaaeenoawuk, the influence of Moravian missionaries, and the importance of visionary leaders, such as Tamaqua, White Eyes, and Captain Pipe--three important factors, imperative to the story of Delaware centralization and nationhood in the Ohio. The stability of a lasting political Delaware nation, however, was undermined by the stress of factionalism in the Great Council as the American Revolution divided Delaware leaders in 1780.

This study will also examine the processes, which led to the fractured state of the Delawares after Washington's Indian War in the Old Northwest Territory and the subsequent Treaty of Greenville that followed in 1795. The story of the Delawares from 1730-1795 demonstrates a dramatic and arduous struggle for autonomy, identity, and political union. In the end, however, the Delaware nation became weakened and broken, driven from the Ohio and forced to migrate west once again. 


\section{Acknowledgements}

There are many people who I acknowledge for their support and inspiration, as I struggled to put together this doctoral dissertation. First of all, a grateful thanks to Holly Mayer of Duquesne University. In 1996, Dr. Mayer served as my adviser as I wrote my Master's thesis on the reciprocal relationship between Cheyenne warriors and their society during the nineteenth century. She showed me how to organize, focus, and present my thoughts--all skills that would be essential when I tackled my dissertation on the emergence of the Delaware Indian nation. Dr. Mayer, together with the history faculty at Duquesne, taught me a great deal about the discipline of research and writing as I prepared to enter my doctoral study at West Virginia University.

My time as a student and teacher at West Virginia University has been most rewarding. I thank the history faculty there for serving as exemplars of professionalism, as teachers, researchers, and writers. Ken Fones-Wolf, Michal McMahon, and John Super were invaluable as my committee members. Their criticisms were always positive and greatly added to the scope of the final dissertation. With deep admiration, I consider myself fortunate to call them my friends and colleagues. Dr. McMahon especially, during his seminar courses, taught me how to write with analytical sophistication but also with purpose and clarity. These were indeed hard lessons, but a gratifying struggle when I met his standards as a writer and thinker.

I would also like to thank Raymond Whritenour, the compiler of A DelawareEnglish Lexicon. He helped me work out the cogs regarding Delaware social structure, organization, and terminology. Raymond also presented assertive arguments regarding his defense of the Moravian missionaries David Zeisberger and John Heckewelder as critical sources for Delaware Indian history.

I highly acknowledge the contributions of James H. Merrell of Vassar College as my outside reader. I met James Merrell at Duquesne University’s History Forum in October of 1999. I asked him if he would serve on my dissertation committee. He responded that he would participate on the condition that he would take an active part in the process and not to merely "rubber stamp" the dissertation. He was true to his word. Dr. Merrell spent part of a summer and part of his Christmas break to edit two of my 
drafts. His comments, critiques, and questions deeply challenged me and helped me to reevaluate the focus and purpose of my study on Delaware Indians. He forced me to consider and to establish in what ways my study broke new ground or offered new perspectives to Delaware Indian or American Indian history, in general. James Merrell's concern for this dissertation, and gracious, yet firm input made the work both extremely difficult and frustrating during the long procedure, but rewarding as I got closer to the mark.

Most importantly, this study would not have been possible without Mary Lou Lustig of West Virginia University. Dr. Lustig served and honored me by being my dissertation adviser for the past six years. She displayed confidence in my ability as a student and showed personal interest in the topic. Her enthusiasm and support were vital as I worked through the process. I laid out the embryonic structure of the dissertation with Dr. Lustig in her Colonial and American Revolution seminar courses. She patiently encouraged me at times when it seemed impossible to complete the dissertation, yet remained firm in her expectations of high academic standards. Mary Lou Lustig, as my teacher and my friend, made the writing experience one that I will never forget.

Lastly I would like to thank my friends and family for their continually support as I researched, wrote, and revised this dissertation over the past four years. Special thanks to my mother, Elizabeth Grimes, who knew me and dealt with me when I was a very poor and unmotivated high school student, and my daughter Emily Sarah, who has been a ray of sunshine in my life since the first day she came into the world. Both served as inspirations as I strove to reach my goals.

I would like to give my love and thanks to my wife Ginny. For over a decade, she has patiently, as a guiding force, helped me to believe in myself throughout my schooling, studying, and research. She listened to my ideas as I was working them out, typed much of the preliminary drafts, and heard my complaints when the computer was not doing what I wanted it to do. Without my wife and best friend Ginny, I would not have made the painful and long transition from a blue-collar worker on a grueling night turn shift, to a historian and teacher. To her I dedicate my doctoral dissertation. 


\section{Table of Contents}

$\begin{array}{ll}\text { Abstract: } & \text { ii }\end{array}$

Acknowledgements:

Introduction: "A powerful nation with a very large train of connexions and allies ..." 1

Chapter 1: "We Conquer'd you; we made Women of you":

The Six Nation-Pennsylvania Chain of Friendship and the Western Migration of the Delawares, 1730-1750

Chapter II: "They Assumed a tone of defiance":

The Military Ascension of Western Delawares, 1750-1756 42

Chapter III: "on behalf of all our Nation":

The Turtle, Turkey, and Wolf Tribes During the Seven Years' War and the Age of Pontiac

Chapter IV: White Eyes, The Great Council, and the United Brethren:

Peacemakers on the Muskingum, 1770-1776

Chapter V: The Delawares and the American Revolution

Chapter VI: "A nation . . . shattered, wrecked, and severed":

$\begin{array}{ll}\text { The Decline of the Delaware Nation, 1783-1795 } & 158\end{array}$

$\begin{array}{ll}\text { Dissertation Conclusion: } & 187\end{array}$

Epilogue: The Delaware Migrations Continue $\quad 192$

Appendix 1: An Ethno-Political Definition of the Delaware Indians 205

Appendix 2: A Historiography of the Delawares as "Women" 213

$\begin{array}{ll}\text { Bibliography: } & 220\end{array}$ 


\section{Introduction}

\section{"A powerful nation with a very large train of connexions and allies ..."}

Through their missionary work, the Moravians David Zeisberger and John Heckewelder came to know and befriend the Lenape or "Delaware" Indians. Zeisberger, a German, and Heckewelder, an Englishman, were sympathetic to the Delawares in their struggles to sustain themselves as a people in the midst of a turbulent Anglo-American colonial and revolutionary world. They were, for the most part, keen observers of Delaware life and respectful of native worldviews, social structures, and cultural values.

Zeisberger and Heckewelder sat in Delaware councils and witnessed first hand both the quest for national unity, the push for political consensus, and the rancor of factionalism among Delaware leaders. In what could be seen as an early American version of public relations work, they exaggerated the political strength, influence, and prominence of the Delawares as a nation. Zeisberger noted that the "Delaware nation [was] looked to for the preservation of peace and entrusted with the charge of the great belt of peace and the chain of friendship" that bound together the Anglo-Indian world of colonial America. ${ }^{1}$ Heckewelder saw the Delawares as "a powerful nation with a very large train of connexions and allies." He considered them to be the spearhead Algonquian nation of a metaphorical "great National Council Fire burning on the banks of the Delaware" including other Indian peoples such as the Mohicans, Conoys, and Nanticokes. Heckewelder recognized the Delawares as the greatest of the Indian nations who resided in the

1 David Zeisberger in Nathaniel Schwarze, trans., Archer Butler Hulbert, ed., "David Zeisberger's History of the Northern American Indians," Ohio State Archaeological and Historical Quarterly 19 (Jan. and April, 1910): 35. Delaware derived from Sir Thomas West, Lord de la Warr, who was appointed governor of Virginia in 1610. Captain Samuel Argall named the Delaware River in West's honor, and those Indian tribes who were settled along this waterway were eventually referred to as Delawares. See John Heckewelder, An Account of the History, Manners, and Customs of the Indian Nations Who Once Inhabited Pennsylvania and the Neighboring States, William C. Reichel, ed., Philadelphia: Memoirs of the Historical Society of Pennsylvania 12 (1876), 26; C. A. Weslager, The Delaware Indians: A History (New Brunswick, New Jersey: Rutgers University Press, 1972), 31-32; Anthony F. C. Wallace, King of the Delawares: Teedyuscung, 1700-1763 (1949; reprint, Syracuse: Syracuse University Press, 1990), 6-7. 
"National Council House"-- a symbolic longhouse that stretched from the Hudson River to the "head tide" of the Potomac. ${ }^{2}$

Both missionaries described the Delaware collective as a union of three large phratries or extended clans. They were Unami and Munsee speakers from the Algonquian linguistic family. Those who spoke the Northern Unami dialect belonged to the Turtle or Packoango tribe ("unfeathered animal"), while southern Unamis made up the Turkey tribe, known as Unalachtigo or Blem ("scratching fowl"). Lastly there were the Munsee speakers or Ptucksit ("round paws"), which was the Wolf tribe. The Turtle, Turkey, and Wolf tribes were hierarchically ranked and comprised the ethnic core of what would eventually become the Delaware political nation. ${ }^{3}$ Despite the reliability of Zeisberger and Heckewelder as sources for Delaware history, the two Moravians haphazardly referred to the Delawares as a national entity that had existed since the beginning of time. They failed to grasp the dynamics of historical processes that contributed both to the emergence and the decline of the Delaware groups as a nation.

Others in the colonial world made the same assumptions of Delaware nationhood. At Fort Pitt in July of 1759, the Indian agent George Croghan greeted the "principal counsellors and warriors of the Delaware nation" when he sought to "ratify and confirm the peace" in the Ohio country. ${ }^{4}$ In October of 1775, Kiashuta, the Seneca orator of the Six Nations of Iroquois, announced to a delegation at Fort Pitt that his people were bound "fast in Freindship" with the Delaware nation..$^{5}$ In September of 1778, the Delawares were once again recognized as a tribal

2 Heckewelder, An Account of the Indian Nations, xxvi, xxxix-xliii, 53.

3 Schwarze and Hulbert, eds., "Zeisberger's History," 92; Heckewelder, An Account of the Indian Nations, 50-53, 249-250. For an in-depth view of what peoples comprised the Delawares and the historical debates centering on the ethno-political composition see Appendix 1: "An Ethno-Political Definition of the Delaware Indians."

4 "Minutes of Conferences Held at Fort Pitt, in July, 1759," in I.D. Rupp, ed., Early History of Western Pennsylvania, and of the West, and of Western Expeditions and Campaigns from MDCCLIV to MDCCCXXXIII (1846; reprint, Lewisburg, Pennsylvania: Wennawoods Publishing, 1995), 132-133.

5 Kiashuta at Fort Pitt Conference, Oct. 12, 1775, in Reuben Gold Thwaites and Louise Phelps Kellogg, eds., The Revolution on the Upper Ohio, 1775-1777 (1908; reprint, Port Washington, New York: Kennikat Press, 1970), 108. 
nation at Fort Pitt. Virginia commissioners, on behalf of the United States Congress, attempted to seal a "perpetual peace and friendship" with the "aforesaid Delaware Nation." 6

The idea of a Delaware nation entered into the writings of the early American novelist James Fenimore Cooper. Greatly influenced by the observations of Heckewelder, Cooper in his early Leatherstocking Tales (The Pioneers written in 1823 and The Last of the Mohicans in 1826), refers to the Delawares as the "favoured people" of the Great Spirit. They were a people honored by Cooper's hero, Uncas, the prominent Mohican warrior of the Turtle totem. In The Last of the Mohicans, Uncas reminds the Delawares that they and the Mohicans are united as one. He also urges the Delawares to remember their greatness as a nation: "Men of the Lenni Lenape! . . my race [Delawares and Mohicans] upholds the earth! . . My race is the grandfather of nations!" The Delawares offer Cooper the tragic symbolism of a powerful and prestigious Indian nation being swept aside by the Anglo-American advance, to become a "nation of mourners"-- a people "scattered, like broken herds of deer. . . ." 7

These observations, whether historical or literary, regarding a functioning and cohesive Delaware nation, bypass the story of a very real struggle among Delawares to gain unity throughout the eighteenth century. The Delaware story of nationhood is hard to unravel. First of all, Anglo-American record keepers, oblivious to the deeper meanings and nuances of events, did not chronicle much of this historical development. As James Merrell mentions, many of the key moments in American Indian tribal evolution have been "lost in the bushes." 8 Secondly, the term "nation," when applied to Native American social and political organization remains a difficult definition to pin down. However, the process of shifting identities, whether white or Indian, remains an important feature of American history. In gaining a clearer picture of the Delaware nation, another piece of America's history is unearthed. The Delaware story of nationhood,

6 Fort Pitt Treaty, Articles II and III, Sept. 17, 1778, in Colin G. Calloway, ed., Revolution and Confederation, vol. 18 of Early American Indian Documents: Treaties and Laws, 1607-1789, Alden T. Vaughan, general ed., (Bethesda, Maryland: University Publications of America, 1994), 167.

7 James Fenimore Cooper, The Last of the Mohicans: A Narrative of 1757, vol.1, bk. 2, The Leatherstocking Tales (1826; reprint, New York: The Library of America, 1985), 778, 821, 830,865 . For more on the demise and dislocation of American Indians as being part of a changing American landscape see Alan Taylor, William Cooper's Town (New York: Alfred A. Knopf, 1995).

8 Correspondence with James H. Merrell, July 31, 2003. 
which is no exception, is a history that needs to be studied and pondered. The story of its rise and deterioration was symbolic of a revolutionary historical period in which many Americans were caught in the dynamic advancement of upheaval and transition.

Throughout the first decades of the 1700s, bands of Delaware Indians, in close geographical proximity and with an ethnic commonality, began the migration from their eastern homes in the Delaware River basin to the Susquehanna and eventually beyond the Allegheny Mountain range to the far reaches of western Pennsylvania and Ohio country. The migration west became the catalyst in the development of a Delaware national identity. The story of this increasing nationalism reflects the dramatic changes underwent by the Delawares during the eighteenth century as the Turtle, Turkey, and Wolf tribes faced new challenges in the west. There the Delaware groups clung to their ethnic roots on a phratry level and eventually strove for autonomy and solidarity on a national level. However, in the west the Delaware tribes could only temporarily sustain a political nation. During the period 1730 to 1795 , the process of nation building among the Delaware tribes was gradual, piecemeal, uneven, and in the end, unfulfilled.

The story of their political unification is complex and reflects the strong influence of other cultures and nationalities. The Delawares during the seventeenth and eighteenth centuries did not live in a vacuum. Their history was shaped by a plethora of peoples during the eighteenth century--Dutch, Swedes, Quakers, Pennsylvanians, Virginians, British, French, Iroquois, and Shawnees. Their emergence from autonomous bands into a more centralized consensual polity was indeed influenced by these Europeans and Indians with whom they interacted. These interactions were crucial in the transformation of the Delaware tribes.

When Europeans entered the regions of the Delaware Indians, they discovered a people who combined hunting with agriculture. They were comprised of autonomous and kin-based bands scattered throughout the Delaware River watershed (or, as it was known, the Lenapewihitak, meaning "River of the Lenape") east to the Hudson River.9 These bands "lacked the strong, cohesive tribal organization" that existed among other tribal entities of that time such as the Iroquois and Huron confederations. Each band had 100 to 250 square miles of hunting

9 Heckewelder, An Account of the Indian Nations, 50-51; Hitakonanu'laxk (Tree Beard), The Grandfathers Speak: Native American Folk Tales of the Lenape' People (New York: Interlink Books, 1994), 6. 
territory. ${ }^{10}$ In 1600 , throughout the eastern seaboard, there was an estimated population of 8,000 Unami and Munsee Indians. ${ }^{11}$

Europeans first met Delaware Indians in 1609 when the English navigator Henry Hudson, sailing for the Dutch East India Company, anchored in what would become Delaware Bay. During the seventeenth century, Delaware Indians came in contact with Dutch and Swedish settlers. By 1664, the English under Charles II claimed the heart of Delaware Indian country-- the territory from the Delaware River valley to the Schuylkill River on which the Lenapes and Munsees (also known as Minisinks) resided. Charles then gave this region to his brother, the Duke of York. ${ }^{12}$ In 1682, York relinquished to the Quaker William Penn his claims to the

10 Thomas Sugrue, "The Peopling and Depeopling of Early Pennsylvania: Indians and Colonists, 1680-1720," The Pennsylvania Magazine of History and Biography 116, No. 1 (January 1992): 10; Marshall Becker, "The Okehocking: A Remnant Band of Delaware Indians," Pennsylvania Archaeologist 46 (1976): 25; William A. Hunter, "Documented Subdivisions of the Delaware Indians," Bulletin of the Archaeological Society of New Jersey 35 (1978), 20-21; Ives Goddard, "Delaware," in Bruce G. Trigger, ed., Northeast. Vol. 15 of Handbook of North American Indians, gen. ed. William C. Sturtevant, (Washington, D. C.: Smithsonian Institution, 1978), 213-215, 225; Marshall Becker, "The Lenape Bands Prior to 1740: The Identification of Boundaries and the Processes of Change Leading to the Formation of the 'Delawares,"' in Herbert C. Kraft, ed., The Lenape Indian: A Symposium (South Orange, New Jersey: Archaeological Research Center, Seton Hall University, 1984), 22. Unami-speaking Delawares lived in such towns as Gweghkongh, Hespatingh, and Mechgachkamic in what is now northern New Jersey, and Katamoonchink, Clistowacka, and Playwickey in eastern Pennsylvania. Munsees and affiliated peoples resided at Papagonk in Ulster county, New York, Peckwes (near current day Hackensack, New Jersey), and Cashiehtunk near the Pennsylvania-New Jersey line of the Delaware River. See John R. Swanton, ed., The Indian Tribes of North America, Bulletin 145 (Washington, D. C.: Bureau of American Ethnology, 1952), 50-54. For this study, the term "band" is in reference to a local unit of fifty to two hundred people, within the tribe. A band lived together in a village, or in Northeastern Woodland Indian terminology, a town. See Sharon O'Brien, American Indian Tribal Governments (Norman: University of Oklahoma Press, 1989), 313-314.

11 Swanton, ed., Indian Tribes of North America, 54-55. These numbers dwindled to 3,000 during the eighteenth century; in the Census of 1910, the Delawares were estimated at a population of 985 .

12 C. A. Weslager in collaboration with A. R. Dunlap, Dutch Explorers, Traders and Settlers in the Delaware Valley, 1609-1664 (Philadelphia: University of Pennsylvania Press, 1961), 11-12. According to Delaware oral traditions, it was on Manhattan Island that Henry Hudson and the Dutch introduced alcohol to the Delawares. The Delaware term Mannahachtanink means "the island or place of general intoxication." See John Heckewelder, in Colin G. Calloway, ed., The World Turned Upside Down: Indian Voices from Early America (Boston: Bedford Books of St. Martin's Press, 1994), 34-38. 
Delaware River and all territory as far north as the 43rd parallel. Penn, given a massive land grant by Charles II in 1681, became proprietor of Penn's Woods; with it, he gained jurisdiction over the majority of Delaware Indians. ${ }^{13}$ At Shackamaxon, outside of modern Philadelphia in November of 1682, a group of Lenape sachems presented Penn with a wampum belt of oystershell beads and fine leather to symbolize a lasting peace and friendship between the Indians of the region and English colonists. ${ }^{14}$

Negotiations in land sales with the Pennsylvania provincial government were done independently by local chiefs and without consent from other Delaware communities. These chiefs were "often of uncertain authority and undefined jurisdiction."15 Traditionally Delawares had no leader to speak for all the animal tribes and bands. The Swedish geographer-engineer Peter Lindestrom visited six Delaware towns on the Schuylkill River in 1654 and noted that all were

13 C. A. Weslager, The English on the Delaware, 1610-1682 (New Brunswick, New Jersey: Rutgers University Press, 1967), 224; Weslager, The Delaware Indians, 155-156.

14 Illustration of a facsimile of the wampum belt presented by Lenapes to Penn at Shackamaxon, November 1682, in Jean R. Soderlund, ed., William Penn and the Founding of Pennsylvania 1680-1684: A Documentary History (Philadelphia: University of Pennsylvania Press, 1983), 145. Wampum belts were symbolic devices made of cylindrical beads and used as records of the meetings. Turning a belt over to read the next belt was the equivalent of turning a page of a book or newspaper. Wampum belts were also used to convey proposals--white belts for peace, a red mark of a hatchet painted on black belts, for war. If the receiver of a wampum belt rejected the proposal, he might refuse to look at it or he might kick it away. For details on council meetings and the function of wampum, see Zeisberger in Hulbert and Schwarze, eds., “Zeisberger's History," 94-99; Heckewelder, An Account of the Indian Nations, 107-112; William N. Fenton, The Great Law and the Longhouse: A Political History of the Iroquois Confederacy (Norman: University of Oklahoma Press, 1998), 224-233; Michael K. Foster, "Another Look at the Function of Wampum in Iroquois-White Councils," in Francis Jennings, William N. Fenton, et. al; eds., The History and Culture of Iroquois Diplomacy: An Interdisciplinary Guide to the Treaties of the Six Nations and Their League (Syracuse, New York: Syracuse University Press, 1985), 99-114.

15 Francis Jennings, The Ambiguous Iroquois Empire: The Covenant Chain Confederation of Indian Tribes With English Colonies from its beginnings to the Lancaster Treaty of 1744 (New York: W.W. Norton \& Company, 1984), 263; Paul A.W. Wallace, Conrad Weiser, 1696-1760: Friend of Colonist \& Mohawk (1945; reprint, Lewisburg, Pennsylvania: Wennawoods Publishing, 1996), 41. With regard to the selling of land, Indians received goods for their land and they rationalized that this was an exchange of gifts between friends. This exchange did not imply that Indians gave up their land. They were giving Europeans the right to use the land, not sole ownership. See Weslager, Dutch Explorers, Traders and Settlers, 109. 
"under six sachems or chiefs, each one commanding his own tribe or people under him. ..."16 Penn considered the Delawares to be lacking unity and less "politically minded" than other tribal groups. ${ }^{17}$ He noted, however, that within every community, the chief had a council, which consisted of "all the Old and Wise men of his Nation." While these chiefs (Penn called them Kings) wielded great authority in their individual towns, the chief was sensitive to the will of his people. Penn witnessed the presence of local councils; no reference was made to any form of a consolidated council of many Delaware tribes. ${ }^{18}$

Observers noted well into the 1730 s that Delaware bands and phratries remained independent of one another and were defined geographically. For instance, Brandywine River Delawares met in their own council and were politically separate from the Tulpehocken Delawares of Pennsylvania. ${ }^{19}$ Various land sales carried out in New Jersey and Pennsylvania identified Delaware Indians as "Schuylkill Indians," "Fall[s] Indians" (those who lived near the Delaware Falls), and "Christiana Indians."20

Early Europeans who settled along the Delaware River drove a wedge between the Delaware communities in eastern Pennsylvania and New Jersey. As Pennsylvania Delawares sold their lands and moved west into the Susquehanna and Schuylkill river valleys, New Jersey

16 Peter Lindestrom, Geographia Americae with an Account of the Delaware Indians, Based on Surveys and Notes Made in 1654-1656, Amandus Johnson, trans., and ed. (Philadelphia: Swedish Colonial Society, 1925), 171.

17 William Penn in Paul A.W. Wallace, "Conrad Weiser and the Delawares," Pennsylvania History 4 (July 1937): 144.

18 Albert Cook Myers, ed., William Penn: His Own Account of the Lenni Lenape or Delaware Indians, Tercentenary Edition (1937; reprint, Wilmington, Delaware: The Middle Atlantic Press, 1970), 36. Regarding the decentralization of Delaware bands: throughout the summer of 1682, Delaware leaders such as Kowyockhickon, Attoireham, Essepamachatte, Kekerappamand, Nahoosey, among many others, made their marks and sold tracts of land to Penn without the restrictions and constraints of a centralized tribal council. See Deed of the Treaty of June 23, 1683, in Myers, ed., William Penn: His Own Account of Delaware Indians, 83.

19 Jennings, Ambiguous Iroquois Empire, 263.

20 Bill of Captain Lasse Cock, presented to Penn, Sept. 24, 1682, in Soderlund, ed., William Penn and Founding of Pennsylvania, 145. Lasse Cock was a Swede who worked for Pennsylvania Governor William Markham as an interpreter and messenger to the local Indians. 
Delawares became isolated. Thus the two tribal bodies had different relations with whites and divergent histories until they merged in the Ohio country at a later date. ${ }^{21}$

Despite this geographic separation, Delaware Indians had a favorable relationship with William Penn and his government. Penn's "Holy Experiment" gave Lenape groups preeminent status over all Indians within Pennsylvania. Penn's death in 1718 and Pennsylvania's need to secure its frontiers from French intrigues with western Indians altered this arrangement with the Delawares. During the 1730s, the government of Pennsylvania entered into a political alliance with the Six Nations of Iroquois (the Mohawk, Seneca, Oneida, Onondaga, Cayuga, and Tuscarora nations). ${ }^{22}$ The Delawares became outcasts in their own homeland. As a result, the Delawares lost their lands and autonomy as they became (by definition of this alliance between Pennsylvania and the Iroquois confederation) subservient to the Six Nations. Alienated from the Penn government, many groups of Delawares moved to the Allegheny and Ohio countries. In this region Delawares gravitated towards powerful leaders who sought independence, defended the Ohio from Anglo encroachments, and forged new political identities.

By the 1780s, influenced by decades of frontier wars (the Seven Years' War and the American Revolution), western Delaware bands became, by necessity, more politically and ethnically united, in defense of both their independence and their new homeland. Delawares eventually embraced a common vision of nation--a polity structured in time of crisis to counter Anglo-American power and aggression. In this sense, the frontier expansion of British America intensified the Delaware need for unification and centralization and thus forced Anglo-Americans to take notice and respond accordingly. These Indians slowly evolved from localized matrilineal families within their respective phratries to specific ethnic groups and lastly, to the defined political divisions that eventually formed the Delaware nation.

21 Hunter, "Subdivisions of the Delaware Indians," 21.

22 The Six Nations of Iroquois consisted of the Senecas, Cayugas, Onondagas, Oneidas, Mohawks, and Tuscaroras. Between the years 1712 and 1732, the Tuscaroras sought refuge among their Iroquoian relatives of the Five Nations. This southern Iroquoian group had escaped annihilation during disastrous Indian wars in the Carolinas known as the Tuscarora War. See J. N. B. Hewitt, "Tuscarora," in Handbook of American Indians North of Mexico, ed. Frederick W. Hodge, Bulletin, U. S. Bureau of American Ethnology, 30, Part Two (Washington, D. C.: Smithsonian Institution, 1910), 847. 
The process of change has always intrigued scholars. Bernard Bailyn, Jack Greene, Edmund Morgan, and Gary Nash, among others, have studied the shifting of cultural and political identities, a definitive feature of colonial Anglo-America. Within the last two decades, historians have explored similar changes among the American Indians of the same era. Trailblazing works such as The Death and Rebirth of the Seneca by Anthony F. C. Wallace, The Invasion Within by James Axtell, James H. Merrell's, The Indians' New World, and Colin Calloway's, The American Revolution in Indian Country have successfully addressed both the factors contributing to changing identities and the adaptive strategies used by natives to counter those challenges. ${ }^{23}$

Little concern, however, has been shown for changing political structures among American Indian groups of the colonial and revolutionary era. The historical experiences of the Delaware Indians during this period present the potential for more study on the phenomena of transformed tribal organization. Michael N. McConnell, in A Country Between: The Upper Ohio Valley and Its Peoples, 1724-1774, chronicles the meshing of eastern Indian migrant groups and how they re-established themselves in the Upper Ohio Valley during the eighteenth century. He notes that Delawares "reconstituted in the west" and coalesced into an ethnic nation. McConnell alludes to "the process of Delaware consolidation," but does not fully explore the historical dynamics of this procedure. ${ }^{24}$ Gregory Dowd, in his study of pan-Indian movements in the Ohio country and Great Lakes during the 1760s, maintains that the Delawares were in a continual state of disunity until they reached the Ohio. By the 1750s, he notes that a "sense of commonality as a people had emerged." According to Dowd, Delaware bands united under a "shared sense of experience" (the migration west) and a common language. ${ }^{25}$ With these enticing, yet general observations,

23 Anthony F. C. Wallace, with the assistance of Sheila C. Steen, The Death and Rebirth of the Seneca (New York: Knopf, 1969); James Axtell, The Invasion Within: The Contest of Cultures in Colonial North America (New York: Oxford University Press, 1985); James H. Merrell, The Indians' New World: Catawbas and their Neighbors from European Contact through the Era of Removal (Chapel Hill: University of North Carolina Press, 1989); Colin G. Calloway, The American Revolution in Indian Country: Crisis and Diversity in Native American Communities (New York: Cambridge University Press, 1995).

24 Michael N. McConnell, A Country Between: The Upper Ohio Valley and Its Peoples, 1724-1774 (Lincoln: University of Nebraska Press, 1992), 225.

25 Gregory Evans Dowd, War Under Heaven: Pontiac, the Indian Nations \& the British Empire (Baltimore: The Johns Hopkins University Press, 2002), 31-33. 
McConnell and Dowd have left open for deeper inquiry the saga of nation building among Delaware tribes.

Duane Champagne and Amy Schutt have also examined the process of Delaware national evolution. They, however, broached only one dimension in the complex history of the Delawares. Both Champagne and Schutt write on the role of religion as the chief ingredient for political unification and a national formation. In "The Delaware Revitalization Movement of the Early 1760s," Champagne focuses on the nativist movements that spawned among the Indians in the Ohio and Allegheny valleys in the later part of the French and Indian War. During this nativist movement, spiritual leaders among the Delawares, such as Neolin, encouraged Indians to reject the materialism of commercial trade with Europeans and to return to more traditional ways of life. Champagne maintains that the Turtle, Turkey, and Wolf tribes of Delawares, in reaction to revitalist trends, united as a centralized political structure. According to Champagne, the Delawares "formed a national unit with recognized chieftainship, a principal chief, head warriors in each phratry, and a national council for collective decision making." 26

Schutt stresses that the Delawares, influenced by the Moravians, drew upon native frameworks, such as the selection of phratry leaders and adapted to "new conceptions of tribal organization" (a centralized structure). ${ }^{27}$ She insists that Moravian missionaries and their converts gained a "reputation as reconcilers" and led the Delawares to political unification and the forging of a national identity. ${ }^{28}$

The views of McConnell, Dowd and in particular, the research of Champagne and Schutt, need strong consideration in the story of the building of a Delaware Indian nation. While the role of religion (whether revivalist spirituality or Christianity) common language and common experiences can all be seen as influential in nation building, they were not the sole driving forces as the means. There are many more important factors and dynamics to be included in the mix.

John Moore, an anthropologist who specializes in the socio-political organization of the Cheyenne Indians of the Great Plains, observes:

26 Duane Champagne, "The Delaware Revitalization Movement of the Early 1760s: A Suggested Reinterpretation,” American Indian Quarterly 12 (Spring 1988): 121-122

27 Amy C. Schutt, "Forging Identities: Native Americans and Moravian Missionaries in Pennsylvania and Ohio, 1765-1782” (Ph. D. diss., Indiana University, 1995), 260.

28 Ibid., 186. 
Nations, like all social institutions of whatever size, have a beginning and an end. But neither the beginning nor the end of a nation's history is determined by chance. Rather, both are controlled by conditions of political economy that can be described in scientific terms. A nation is like a biological individual. It is born from the shared needs of possibly diverse people who group[ed] together out of self-interest. ${ }^{29}$

Much of this analogy could be applied to Delaware Indian groups of colonial America. Delawares slowly unified throughout the eighteenth century in response to their repressive treatment at the hands of the Pennsylvania-Iroquois alliance, their sense of common cause as they migrated west, and their need to persevere in the geo-political environment of the Ohio country. This regional identity was further enhanced once western Delawares permanently separated themselves, at least politically, from their eastern kin remaining on the Susquehanna. In doing so, they removed themselves from their traumatic past to become reborn as a people, exposed and receptive to new possibilities of political integration.

In their new western homeland, influential tribal leaders, such as Tamaqua, Shingas, White Eyes, Captain Pipe, and Buckongahelas came to the forefront to express and lobby for their distinct visions of Delaware destiny to a Great Council, congregated inside a national council house. Most importantly, while McConnell, Champagne, and Schutt treat the political consolidation as a finished product, there is a need to take the story a step further--a need to make a more realistic appraisal of the Delaware nation as it entered the nineteenth century.

Delaware unity was fragile and short-lived. The three animal tribes of Delawares consolidated by 1765 and did so in response to the presence of British military in the Ohio. McConnell, Champagne, and Schutt have each contributed to an invaluable foundation in unraveling the story of the Delaware Indian nation. They, however, have failed to see the paradoxical nature of this national growth. When the American Revolution entered Indian country in 1780, a consolidated nation, as furthered by McConnell, Champagne, and Schutt, became greatly undermined by forces brewing beneath the surface. As Delawares strove for unifying the 
three animal tribes, the nation was being simultaneously torn apart by factionalism, that being the internal conflict between the pro-American faction of White Eyes and the pro-British Captain Pipe. Unity was not strong enough; the Delaware nation was not mature enough to withstand the factionalism that disrupted both the Great Council and the trajectory of a developing nation. By 1795, with an American military invasion into Ohio, the Delaware nation was greatly weakened. Delawares became geographically, ethnically, and politically scattered once again.

This dissertation will examine the tangents in the forming of a Delaware nation, but also consider the factors that led to its quick decline by 1795 . Historians have scratched the surface or established a plausible framework for explaining the growth of the Delaware Indian nation. This study, however, will show the full progression of the Delaware nation and also detail the longignored facet of national decline and downfall. Thus the story of Delaware nationhood from 1730 to 1795 demonstrates a fight for independence and unity and the futile struggle to erect and maintain a stable political edifice. In the end, however, the Delaware polity became fragmented--a quasi-Indian nation forced, as in the past, to migrate west.

29 John H. Moore, The Cheyenne Nation: A Social and Demographic History (Lincoln: University of Nebraska Press, 1987), 14. 


\section{Chapter I}

\section{"We Conquer'd you; we made Women of you": \\ The Six Nations-Pennsylvania Chain of Friendship and \\ the Western Migration of the Delawares, 1730-1750}

In Philadelphia on July 9, 1742, Pennsylvania governor George Thomas met in council with chiefs of the Six Nations of Iroquois, Sassoonan (also known as Alumapees) of the Schuylkill Delawares, and Nutimus, a leader of the "Fork Indians" (Munsee-Delawares). The purpose of the meeting was to remove Nutimus's people from the land surrounding the Forks of the Delaware River when they failed to honor a treaty allegedly made fifty years earlier, which relinquished Indian rights to this region. ${ }^{1}$ Thomas condemned the "Insolence" of those Delawares who had sent written protests to Pennsylvania magistrates regarding this recent land cession. Delaware leaders contended that Pennsylvania officials had cheated them out of their remaining homeland. Thomas accused the Delawares of treating the proprietors with the "utmost Rudeness" and asked the Iroquois delegation to "punish them as they deserve." 2 Three days later, on July 12, the Onondaga orator Canasatego asserted his authority as a powerful spokesman and chastised his "Cousins" (Nutimus and other Delaware leaders) for selling land that he believed they had no right to sell, and then wanting the land back. He called the Delawares an emasculated and conquered people who did not have the strength to hold onto their land. Nutimus and the Delaware council left in disgrace and bitterness. ${ }^{3}$

By these actions in 1742, the Six Nations formally proclaimed their dominance over the Delawares of Pennsylvania. The scathing rhetoric of Canasatego demonstrated the political

${ }^{1}$ Minutes of the Provincial Council of Pennsylvania From the Organization to the Termination of the Proprietary Government, 16 vols. (1851; reprint, New York: AMS Press 1968), 4: 575-576 (hereafter MPCP). Sassoonan's Schuylkill Indians were southern Delawares and were distinct from Nutimus and the northern bands. See William A. Hunter, "The Ohio, The Indian's Land," Pennsylvania History 21 (1954): 342.

MPCP 4: 575.

3 Canasatego in ibid., 4: 579. The term "cousin" is also confusing. It does not suggest equality. According to Conrad Weiser, 1696-1760, Indian agent to the Mohawks, the term cousin signified one "under Command" of another. See Wallace, Weiser, 271, 450. 
climate in Pennsylvania at that time. The Iroquois placed a stigma on the proud Delawares when they ridiculed their status as peacemakers or women. Iroquois dominance led to tensions between the Delawares and the Proprietors of Pennsylvania and accelerated the migration of Delawares from their homeland in the Delaware and Susquehanna River valleys to land west of the Allegheny Mountains. Many Delawares became involved in the search for a new homeland and strove to retain their self-esteem as a people.

The Six Nations-Pennsylvania alliance drastically transformed the world of the Delaware Indians. However, the very nature of colonial Pennsylvania at that time, with its expanding white settlements, the rum trade, and the lack of game was equally detrimental to the Delawares. These demographic pressures forced them to seek solutions through western migration.

The final straw was the humiliation heaped upon Delaware leaders by Canasatego. Much of Canasatego's rhetoric can be seen as bluster--a political maneuver to elevate Iroquois influence in the eyes of the Anglos at the expense of vulnerable Delaware leaders. Canasatego threatened Nutimus: "You ought to be taken by the Hair of the Head and shak'd severely till you recover your Senses and become Sober ... Your Cause is bad, your Heart far from being upright, and you are maliciously bent to break the Chain of friendship with our Brother Onas (the Pennsylvania governor)...." He then tried to alter the once-honorable intention of the diplomatic metaphor of "woman." Canasatego reminded the Delaware leaders, "We conquer'd You, we made Women of you, you know you are Women, and can no more sell Land than Women." 4 Canasatego then claimed for the Iroquois the rights to land south of the Kittatinny Mountains, a territory to which the Six Nations had no rights.

Canasatego represented a confederation of Indian nations that carried great clout in the Anglo-Indian world of colonial America. The Iroquois Confederation was very important in the story of the development of a Delaware nation. The role and subsequent actions of the Five, and later after 1730, the Six Nations, influenced directly or indirectly by Europeans, had immense impact upon the politicization and unification of once-decentralized Delaware bands.

The relationship of the Delawares with the Six Nations is embedded in both native oral traditions and the colonial historical record. Key to this relationship was the transformation of

${ }^{4}$ For Canasatego's speech on July 12, 1742 see MPCP 4: 579. For a narrative on this event see Jennings, Ambiguous Iroquois Empire, 342-346; Wallace, Teedyuscung, 37-38; Weslager, The Delaware Indians, 190-192. 
the cultural / diplomatic metaphor of "woman" and how it applied to the Delawares throughout history. In Lenape oral history, they at one time lived near the Namesi Sipu, the "River of Fish" (Mississippi River). In this western country, the Lenape lived close to the Mengwe (Iroquois). As both people moved to the east in search of a permanent homeland they came across the Alligewi or Allegheny tribes of the Ohio. ${ }^{5}$ The Allegheny tribes became alarmed when the Lenape and Iroquois entered their country. They "made a furious attack" on the two groups. 6

Lenape and Mengwe warriors united to fight the Alligewis. A great battle ensued in which "Hundreds fell." The Allegheny tribes deserted their towns on the Alligewi Sipus (Allegheny River) and fled to the Mississippi country. ${ }^{7}$ Eventually the allied Lenape and Iroquois tribes separated and moved to new homelands. The Lenape settled on the "four great rivers," the Hudson, Susquehanna, Potomac, and Delaware. The Iroquois moved to inhabit the region between the Hudson River to the western shores of Lake Erie and north to the periphery of the St. Lawrence River. They became known as the Haudenosaunee ("We of the Extended Lodge"). ${ }^{8}$ After generations of peaceful relations, tensions arose between the two neighbors. According to the Lenape traditions, the Iroquois became jealous of Lenape strength and treacherously conducted war excursions into Lenape'hokink (Land of the Lenape), "frequently surprising them at their hunting camps." 9 The Mengwe, "finding that they were no match for so powerful an enemy as the Lenape," entered into a confederation of five Iroquois nations_- "by which they would be bound to make a common cause, and meet the common enemy with their united force. ..." 10

${ }^{5}$ Heckewelder, An Account of the Indian Nations, 47-49.

${ }^{6}$ Ibid., 49.

${ }^{7}$ Ibid., 50.

${ }^{8}$ Ibid., 50-51; Hitakonanu'laxk (Tree Beard), Grandfathers Speak, 6.

${ }^{9}$ Heckewelder, An Account of the Indian Nations, 54.

${ }^{10}$ Ibid., 55. This is the Delaware version (as related to Heckewelder) regarding the formation of the Iroquois Great League of Peace, sometime during the fifteenth or sixteenth centuries. Of course, the Iroquois rationale regarding the formation of this league is quite different. Their oral traditions maintain that the five tribes of Iroquois were in constant warfare with one another. The Huron prophet Deganawidah, together with the Onondaga war captain Hiawatha, traveled from village to village teaching the Iroquois the value of strength and unity as a way to gain peace and security. They brought the Great Law of the League to the Iroquois Confederation. The period of their gradual formation has been estimated from 1142 to 1580 . See Arthur C. Parker, The Constitution of the Five Nations or the Iroquois Book of the Great Law 
Bloody conflict followed, with the Delawares being the victors on many occasions against the Five Nations during the early seventeenth century. At the same time the French settled in Canada and placed great pressure on the confederated Iroquois tribes. The Five Nations could no longer afford a war on two fronts. The leaders of the Iroquois tribes sought peace and entered into an alliance with the Delawares. ${ }^{11}$

An arrangement between the Lenapes and Iroquois was reached at Nordham's Kill (outside of present-day Albany) in the early 1600s. The Five Nations needed a powerful ally to gain border security and did so by making an alliance with the Delaware tribes. ${ }^{12}$

This plan was very deeply laid, and was calculated to deprive the Lenape and their allies, not only of their power but of their military fame, which had exalted them above all the other Indian nations. They [the Delawares] were to be persuaded to abstain from the use of arms, and assume the station of mediators and umpires among their warlike neighbours. In the language of the Indians, they were to be made women. ${ }^{13}$

(Albany: New York State Museum, Bulletin No. 184, 1916), 97-113; Fenton, Great Law and Longhouse, 51-65; Leon Shenandoah, foreword to Paul A. W. Wallace, The White Roots of Peace: The Iroquois Book of Life (1946; reprint, Santa Fe: Clear Light Publishers, 1994), 13.

${ }^{11}$ Heckewelder, An Account of the Indian Nations, 55-56.

12 Ibid., 60-62. Heckewelder gained information from a Reverend C. Pyrlaeus, who contended that the Dutch arranged for this alliance at Nordham's Kill. The Dutch wanted to disarm the Delawares, whom they saw as a serious military threat. Most importantly, neither Pyrlaeus nor the Moravian missionary David Zeisberger (both of who intimately knew the Iroquois) heard of any epic battle in which the Five Nations routed and conquered the Lenapes. This battle seems to be entrenched in Lenape oral traditions. Zeisberger maintains that the title of "woman" meant the Delawares were highly respected as peacemakers. The Iroquois "recognized the superior strength of the Delawares" and wanted to avoid a war that they might lose. See Hulbert and Schwarze, eds., "Zeisberger's History," 34. Delaware traditions also recognized themselves as the prominent peacemakers and the Five Nations as the warriors in this alliance. See Daniel Brinton, The Lenape and Their Legends; With the Complete Text and Symbols of the Walum Olum (1884; reprint, New York: AMS Press, Inc., 1969), 110, 114, 120. Delawares may have also inflated their own importance, as did the Iroquois when they asserted a mythical dominance over other tribes.

${ }^{13}$ Heckewelder, An Account of the Indian Nations, 56. For a more in-depth historiographical discussion and cultural analysis on the term "woman," see Appendix 2. 
Delaware oral traditions argue that only a "powerful nation" could be designated as women in an alliance. During the 1820s, an aged Lenape informant told John Heckewelder that "As men they had been dreaded; as women they would be respected and honored, none would be so daring or so base as to attack or insult them. ..." Heckewelder contends that the term woman was not a label of weakness or subjugation. Only a people of strength, wisdom, and influence, such as the Lenape, could attain the title of women among Algonquian speakers. ${ }^{14}$ Once again the Moravians may have invented or elaborated upon the potency of a collective Delaware people.

In the written historical context, there are other explanations regarding this relationship between the Delawares and Iroquois. In 1677 New York Governor Edmund Andros, together with Daniel Garacontie of the Onondagas, united his colony and his Iroquois allies with other English colonies to form the Covenant Chain of Peace. This chain became a "bisocietal structure including both tribes and colonies"--an alliance of New York, New England, Maryland, and Virginia with the Five Nations of Iroquois, refugee Algonquian tribes from King Philip's War who now resided in Andros's colony, and all tribes who were tributaries of the Iroquois. Both the English and the Five Nations needed to ally with each other as a way to counter French presence on the periphery of English northern colonies and, in the case of the Iroquois, to counter the increasing-strength of Algonquian tribes in the west. Since many of the Delaware bands at this time lived within the confines of New York colony, they became part of this alliance. Delawares, alarmed at the increasing racial violence on the borders of Virginia and Maryland between Indians and colonial militias, sought the protection offered by Andros and his covenant. The Iroquois gave the Delawares the metaphorical title of women. This title only "implied a degree of subordination" to the Five Nations and was a political "by-product" of this Covenant Chain. ${ }^{15}$

14 Ibid., 58.

${ }^{15}$ Francis Jennings, "The Delaware Indians in the Covenant Chain," in Herbert C. Kraft, ed., A Delaware Indian Symposium (Harrisburg: The Pennsylvania Historical and Museum Commission, 1974), 90; Mary Lou Lustig, The Imperial Executive in America: Sir Edmund Andros, 1637-1714 (Madison, New Jersey: Fairleigh Dickinson University Press, 2002), 85-86; Jennings, Ambiguous Iroquois Empire, 160-161. Andros sought a powerful alliance between New York and the Five Nations, but he also wanted to protect his colony from the encroachment of New Englanders who entered New York and offered the Mohawks bounties for the scalps of refugee New England Indians. These Indians had fled to New York at Andros's invitation in the aftermath of King Philip's War in 1675--a violent uprising of Algonquian tribes against the 
In theory, as part of the Covenant Chain of 1677, the Delawares, in the prestigious role of peacemaker, had the responsibility to mediate between the Five Nations and all eastern Algonquians. In this alliance, the Delaware groups were made tributaries, in a political sense, of the Iroquois, even though the Five Nations had not conquered them. Under the structure of the Covenant, the Iroquois would act as spokesmen for the Delawares in addressing the government of New York. ${ }^{16}$

In reality, there was a great deal of confusion and misinterpretation regarding the actual status of the Delaware groups brought into the chain. The Iroquois believed that the Five Nations held a political domination over all Indian people within the Covenant. However, the Delawares refuted much of Iroquois claims of dominance and at the same time, the Delawares exaggerated the importance of their gender designation as women.

Despite the delusions of Iroquois supremacy, from the Delaware point of view, they underwent a "tribal transformation" during the European colonization of America. Delawares had a military potential comparable to that of the Six Nations, but without a cohesive political structure such as the Iroquois Confederation, the majority of Delaware bands veered towards a course of pacifism and thus gained the symbolic metaphor of "women." In Regula Trenkwalder Schonenberger's study of the Delawares and their alliance with the Six Nations, she contends that the "burdens of international alliances and bloody wars fell to the Iroquois." In accepting their gender designation as women, the Delawares embraced an ethos of "pacifist resistance." ${ }^{17}$ They

Puritans of New England. Andros, concerned at the potential problems posed by these New Englanders, created the alliance of the Covenant Chain. Andros also offered refuge to Susquehannocks and protected them from Maryland revenge. Maryland wanted to use the Iroquois to police the Chesapeake frontiers and to deliver some of these Susquehannock refugees to Maryland where they would be tried for frontier atrocities against their colonists. Andros would not permit the Five Nations to serve Maryland as policemen. Also see Stephen Saunders Webb, 1676: The End of American Independence (Syracuse: Syracuse University Press, 1984), 355-405; Lustig, The Imperial Executive in America, 67-98. At the covenant treaty talks in Albany, Maryland colonial officials referred to the Delawares as "Mattawass or Delaware Indians." See William Hand Browne, ed., Archives of Maryland: Proceedings of the Council of Maryland, 1693-1697, 69 vols. (Baltimore: Maryland Historical Society, 1887-1903), 5: 269.

${ }^{16}$ Jennings, Ambiguous Iroquois Empire, 160. It is Jennings's point that the Five Nations served as the spokesmen to the government of New York on behalf of the Delawares.

${ }^{17}$ Regula Trenkwalder Schonenberger, Lenape Women, Matriliny, and the Colonial Encounter: Resistance and Erosion of Power (c. 1600-1876) (Bern, Switzerland: Peter Lang, Inc., European Academic Publishers, 1991), 243. 
believed that they had entered into this alliance from the point of strength and honor. Whatever the hidden agenda of the Iroquois might have been, it is hard to accept that a martially skilled and diplomatically savvy people like the Delawares would have accepted such a status if they felt it was derogatory.

With the entrance of the Penn proprietorship in 1681, the Delawares remained as members of the Covenant Chain, despite the exclusion of Pennsylvania from the alliance. Iroquois influence in Pennsylvania was minimal. Delaware leaders in Pennsylvania and New Jersey interacted with Penn's government "without Iroquois supervision or participation." ${ }^{18}$ Delawares vacillated in recognizing their tributary status with the Iroquois League; perhaps for political expediency. In 1712, a Delaware delegation led by Scollitchy and Sassoonan of the Turtle phratry presented Pennsylvania Governor Charles Gookin with thirty-two wampum belts. These belts chronicled the history and obligations of the Delaware - Iroquois alliance. The belts also acknowledged the Delaware role as women and a subdued people within the Covenant Chain. ${ }^{19}$

Delawares were not always so humbled with regard to their political status within the Chain. There is evidence that the Delawares resisted this politically subservient position with the Iroquois Confederation and exhibited a degree of independence. Pennsylvania tribes ignored mandates from the central council fire at Onondaga as early as 1694. In that year, Delaware and Conestoga (previously known as Susquehannocks) leaders refused to join the Five Nations on a war expedition against the French and returned the wampum belts of war. Delaware leaders received a curt message from the Five Nations: "You Delawares do nothing but stay at home and boil your pots, and are like women; while we Onondagas and Senecas go abroad and fight against the enemy. ${ }^{20}$ Sassoonan, a proponent of the alliance between his people and the Iroquois, noted in 1718 that despite their status as peacemakers, his people had the rights to sell their own land.

18 Jennings, "Delaware Indians in Covenant Chain," in Kraft, ed., Delaware Indian Symposium, 93.

${ }^{19}$ Delawares in council with Governor Gookin, Philadelphia, May 16, 1712, in MPCP 2: $57-574$.

${ }^{20}$ Message of the Iroquois as relayed by the Delaware orator named Hithquoquean to Pennsylvania Lieutenant Governor William Markham in Philadelphia, July 6, 1694, in MPCP 1: 410-411. 
"Those Nations [Iroquois] have their own Lands and Countrey and these here [Delawares] have theirs, and each of them are to Manage their own concerns." 21

In 1726 or 1727 the Six Nations issued orders to Delaware and Shawnee headmen to help them with an assault on English settlers, who had moved beyond the Susquehanna and whom the Confederation feared were gradually encroaching upon Iroquoia. The Six Nations incited these Pennsylvania tribes: "our Land is goeing to bee taken from us, Come brothers assist us Lett us fall upon and fightt with the English." The Delawares and Shawnees refused to participate in this war against white settlers. In anger the Six Nations told the Delawares, "Since you have nott hearkened to us, nor Regarded whatt we have said, now wee will [put] pettycoats on you, and Look upon you as women for the future, and nott as men. ..." They then commanded the Shawnees to "Look back toward Ohioh" and return home. To save face, the Six Nations agreed to cease hostilities against the English settlers and "Lett them have all this Land." 22 These incidents demonstrate that "Iroquois hegemony over tributary tribes was not absolute rule."23

However, the Iroquois Confederation remained a potential military threat to the Delawares. This reality determined the Lenapes' need to remain on amiable terms with the

${ }^{21}$ Sassoonan quoted in Jennings, "Delaware Indians in Covenant Chain," in Kraft, ed., Delaware Indian Symposium, 93-94. The Delawares were required to pay tribute in wampum to the Iroquois. Delawares were called Hiyonwaate (nephew) by the Cayuga and put under the Iroquois Great Tree of Peace as a younger relative of the Five Nations. The Iroquois considered the Delawares to be props of the Confederacy who reinforced the strength of the symbolic Iroquois Longhouse. See Anthony F. C. Wallace, "Women, Land, and Society: Three Aspects of Aboriginal Delaware Life," Pennsylvania Archaeologist 17 (1947): 21-22.

22 A Shawnee chief named Newcheconner relayed this story, at a later date, to Pennsylvania Deputy Governor Patrick Gordon in Philadelphia in 1732. See Pennsylvania Archives, Samuel Hazard, ed., 1st series, 12 vols. (Philadelphia: Joseph Severns and Company, 1851-1852), 1: 329; Indian speeches in Sylvester K. Stevens and Donald H. Kent, eds., Wilderness Chronicles of Northwestern Pennsylvania (Harrisburg: The Pennsylvania Historical and Museum Commission, 1941), 6-7.

23 Jennings, Ambiguous Iroquois Empire, xix, 215, 301. According to Jennings, despite the importance of the Covenant Chain as a cornerstone of Anglo-Iroquoian solidarity, the Delawares "paid little attention to Iroquois pretensions of superiority." In fact, the label of Delawares as "weakling women" was pure nonsense, for the Delawares "constituted one of the most powerful eastern tribes" of the colonial era. Jennings, Ambiguous Iroquois Empire, xix, 215. Jennings, a long-time skeptic of Iroquois imperial supremacy over other tribes, is skeptical of this relationship between Delawares and Iroquois. He has always disregarded what he sees as the mythology of Iroquois imperial status--his direct challenge to the Francis Parkman-Lewis Morgan hypothesis of "super Iroquois." 
Iroquois within the Covenant Chain. Hence, while Penn's Indian policy of friendship and protection were welcomed, Delaware bands remained concerned with Iroquois power and influence and accepted their status as women, providing it remained an honored title.

It is highly probable that Delaware tributary status was corrupted because the English associated tributary status with European concepts of feudalism, which was characterized by subservience, responsibilities, and dominance. The Delawares were not a conquered people, and for the most part, refused to succumb to Iroquois authority when it overstepped the boundaries of reciprocal relations. This obstinacy towards the Iroquois also increased when Delawares experienced a positive relationship with William Penn and his agents, who, according to Thomas Penn, had "treated them as his Children \& Friends. ..." ${ }^{24}$ Penn negotiated directly with the regional Indians and placed the Delaware tribes under his protection. In Pennsylvania the Delawares were subordinate to Penn and not the council fire at Onondaga. The Delaware tribes were acknowledged as Pennsylvania's Indians. ${ }^{25}$

The Delawares received equitable treatment from the Penn government and in return got along well with the increasingly large numbers of European newcomers who entered the Delaware River region. ${ }^{26}$ With this growth, Pennsylvania's "borderlands became a more complicated, more contentious place." New settlers slowly encroached upon the lands of the Delaware and Shawnee tribes. The death of Penn in 1718 changed the destiny of the Delawares as they gradually became diminished players in Pennsylvania's relationship with Indian nations. ${ }^{27}$

In a shocking turn of events for the Delawares, Pennsylvania authorities befriended the Iroquois. A shift in Pennsylvania politics in 1726 drove Governor William Keith from office to be replaced by Patrick Gordon, who in turn, reappointed the influential Secretary James Logan to head Pennsylvania's Indian policy. In July 1727, several chiefs of the Five Nations came to

24 Thomas Penn to a delegation of Delawares, Aug. 20, 1736, in MPCP 4: 54.

25 Jennings, "Delaware Indians in Covenant Chain," in Kraft, ed., Delaware Indian Symposium, 91. In 1691, the English Crown suspended Penn's charter. Pennsylvania became a Royal colony under the jurisdiction of New York. In 1694, William and Mary restored Penn's charter of Pennsylvania. See Soderlund, ed., William Penn and Founding of Pennsylvania, 14-15.

${ }^{26}$ James H. Merrell, Into the American Woods: Negotiators on the Pennsylvania Frontier (New York: W.W. Norton \& Company, 1999), 35; Carl Bridenbaugh, "The Old and New Societies of the Delaware Valley in the Seventeenth Century," The Pennsylvania Magazine of History and Biography 100 (1976): 143-172.

${ }^{27}$ Merrell, Into the American Woods, 36. 
Philadelphia and met with Gordon and Logan. They were willing to gain a stronger relationship with Pennsylvania by offering to cede their claims of the Lower Susquehanna River region to Pennsylvania. ${ }^{28}$ Gordon and Logan saw a golden opportunity to gain a powerful ally and to use the power of the Six Nations to prevent the French from gaining influence with Indians on the periphery of the Pennsylvania colony. Logan, exaggerating the Iroquois control over their allies, announced: "A treaty should be sett on foot with the Five Nations, who have an absolute authority as well over the Shawanese as all our Indians." 29

This assertion of authority would not be an easy task for the Iroquois Confederation. The Six Nations could not control the Delaware bands that lacked a centralized council and were scattered geographically from the Delaware to the Susquehanna River valleys. Because of demographic pressures, Delaware Indians by the beginning of the eighteenth century settled in three principal geographic regions. The Schuylkill Indians, recognized by William A. Hunter as an "aggregation, and at least a partial unification of bands" from southeastern Pennsylvania and New Jersey, would slowly evolve to become the heart of the Delaware nation. These Indians chose Sassoonan to be their chief spokesman. Most of these Unami-speaking Indians lived in the cultural area known as Tulpehocken, in current - day Berks and Lebanon counties. Delawares called this place "the land of the Turtles." 30

28 Jennings, Ambiguous Iroquois Empire, 304. This region had been previously deeded by the Onondagas to New York Governor Thomas Dongan (1683-1688) at an earlier date and also sold by the Susquehannocks to William Penn in 1701. The Five Nations eagerness to approach Pennsylvania was a result of their neglect by New York officials. The New York government looked the other way as furs from Canada were smuggled into Albany, thus economically crippling the Five Nations. By 1705 the fur monopoly once enjoyed by the Confederation was gone. See Thomas Elliot Norton, The Fur Trade in Colonial New York, 16861776, (Madison: University of Wisconsin Press, 1974), 56, 67.

29 Statement of James Logan, 1731, in Julian P. Boyd and Carl Van Doren, eds., Indian Treaties Printed by Benjamin Franklin, 1736-1762 (Philadelphia: Historical Society of Pennsylvania, 1938), xxiii.

${ }^{30}$ MPCP 1: 447; Weslager, The Delaware Indians, 178-179; Hunter, "Subdivisions of the Delaware Indians," 22-24; Champagne, "Delaware Revitalization Movement," 110-111; Marshall J. Becker, "The Boundary Between the Lenape and the Munsee: The Forks of the Delaware as a Buffer Zone," Man in the Northeast 26 (Fall 1983): 13. Tulpehocken, near modern Reading, Pennsylvania, was an extensive Indian region that connected Unami-speaking Delawares with Munsee-speaking Delawares and Susquehanna Shawnees. See Eric Hinderaker, Elusive Empires: Constructing Colonialism in the Ohio Valley, 1673-1800 (New York: Cambridge University Press, 1997), 124. 
Another locality, the Brandywine River area, accommodated mostly New Jersey Delawares who migrated into the valley of the Brandywine in southeastern Pennsylvania. Independent of the Schuylkill Indians, the Brandywine bands selected Checochinican ("person of few words") to speak for them. Lastly, there were other New Jersey Indians who migrated across the Delaware River to settle on the west branch of the Lehigh River where it joined the Delaware River to the Blue Mountains. Nutimus and Tishcohan, both of the Wolf phratry, and the Turtle leader known as Lappawinzo, led these "Forks" people, an amalgamation on northern Unami and Munsee speakers. They contended that they were not newcomers to the forks and that this region was the land of their ancestors. ${ }^{31}$ Each of the three, though connected to one another in geographical closeness, had a singularly strong regional distinctiveness and had not reached any degree of unification on a national level.

Ironically, while this decentralized state worked to an advantage for the Delawares, it also made the Delawares politically impotent as a voice in colonial Pennsylvania. They could not fully oppose or show resistance to the new relationship between Pennsylvania and the Six Nations. According to John Heckewelder, the eventual alliance had left the Delawares "defenceless" and was forged "for the purpose of shutting their mouths, prevent them from stating their complaints and grievances, and asking redress" from the Pennsylvania government. ${ }^{32}$

Pennsylvania's alliance with the Iroquois was a severe and sobering blow to the Delawares. The Iroquois and Pennsylvania solidified peace by forming a southern branch of the chain, independent from the original Covenant Chain among the Iroquois, New York, New England, and the Chesapeake colonies. ${ }^{33}$ On October 13, 1736, in Philadelphia, James Logan hoped that Pennsylvania's Treaty of Friendship with the Six Nations would last "so long as the Sun, Moon, \& Earth [shall] endure." 34

${ }^{31}$ MPCP 1: 447; Weslager, The Delaware Indians, 178-179; Hunter, "Delaware Sub Divisions," 22-24; Champagne, "Delaware Revitalization Movement," 110-111; Becker, "Boundary Between the Lenape and Munsee," 13.

32 Heckewelder, An Account of the Indian Nations, xxxiii.

33 Jennings, "Delaware Indians in Covenant Chain," in Kraft, ed., Delaware Indian Symposium, 96-97; Merrell, Into the American Woods, 174-175.

${ }^{34}$ Logan to an Iroquois delegation in MPCP 4: 90; Frederick B. Tolles, James Logan and the Culture of Provincial America (Boston: Little, Brown and Company, 1957), 169. Pennsylvania declined to be part of the Covenant Chain with colonial rival New York. To 
In this new alliance, Logan permitted Iroquois war parties safe passage through Pennsylvania as they moved south to attack their traditional Cherokee and Catawba enemies. He promised the Iroquois that he would confine the rum trade to the Susquehanna area and keep these traders away from Iroquois warriors as they moved south on the war trails of Pennsylvania. Logan guaranteed the Six Nations a more "reasonable" and better quality of trade goods "than from those of New York. . . ." 35

In return, the Iroquois agreed to police the frontiers of western Pennsylvania and keep this region secure from French encroachment and western Indian aggression. ${ }^{36}$ Kanickhungo, the Seneca orator, reassured Logan that though a few Iroquois were living in peace with the French in Canada, they would "bring back our People" to defend the peripheries of Pennsylvania "if any new Breach [in the peace] should happen.", 37

The Six Nations Confederation was also given jurisdiction over Pennsylvania's Indians. ${ }^{38}$ The Proprietary Thomas Penn hoped that Logan's new Indian policy would "strengthen the hands of the Six Nations, and enable them to be the better answerable for their Tributaries." 39 The Iroquois leaned heavily upon the "rights of conquest" theory as they reminded colonial officials that they had defeated the Conestogas and assumed territorial control of their land. ${ }^{40}$

accommodate their own interests, Pennsylvania created an independent southern part of the Covenant Chain with the Iroquois. The Treaty of Friendship had originally been concluded in 1732, but not finalized until 1736. Leaders of the Six Nations were reluctant to come to Philadelphia, which suffered through smallpox epidemics. Also see Fenton, Great Law and Longhouse, 404.

${ }^{35}$ Logan to Iroquois in Philadelphia, Oct. 14, 1736, in MPCP 4: 93-94.

36 Jennings, "Delaware Indians in Covenant Chain," in Kraft, ed., Delaware Indian Symposium, 96-97; Wallace, Weiser, 44-45.

${ }^{37}$ Kanickhungo to Thomas Penn and James Logan in Philadelphia, October 2, 1736, in MPCP 4: 85.

${ }^{38}$ Pennsylvania was slowly veering towards this alliance with the Iroquois. Years before the signing of the treaty, Pennsylvania officials told Confederation leaders that with an alliance, the Iroquois would have "an absolute Authority" over all Indians in Pennsylvania, and would have the right to "command them as they please." See Pennsylvania officials to Iroquois, September 1, 1728, in MPCP 3: 329-330.

39 Thomas Penn to Richard Peters, Jan. 10, 1756, Penn Letter Books, Philadelphia: Historical Society of Pennsylvania, 4: 205-207.

40 Francis Jennings, "The Delaware Interregnum," The Pennsylvania Magazine of History and Biography 89 (April 1965): 184-185. For the details on the defeat and subjugation of the Susquehannocks (later known as Conestogas), see Francis Jennings, "Glory, Death, and 
Kanickhungo declared that he not only spoke for the Confederation, but also spoke for "the Delawares, Canayes [Conoys], \& the Indians living on the Sasquehanna, \& all the other Indians who now are in League \& Friendship with the Six Nations ..." 41 The Iroquois, however, respected Lenape rights to land drained by the Delaware River. ${ }^{42}$ At least for the time being.

In the Treaty of Friendship between the Six Nations and Pennsylvania, "men in the Iroquois capital of Onondaga and Philadelphia worked to control the native peoples living between them." ${ }^{43}$ Thomas Penn reminded the Six Nations that "We will constantly keep a Fire for you here at Philadelphia and the Towns of the Six Nations, which we will on our parts, clear from every Grub, Stump \& Log, that it may be straight, smooth \& free for us and you.” The once-honored Pennsylvania tribes of Delaware Indians were not only metaphorically reduced to debris and obstacles but also in a demeaning tone, referred to by Penn as "our Indians." 44 The Delawares had lost their diplomatic stature and eventually were wrested from their homelands. ${ }^{45}$

Land became a major point of contention as Pennsylvania sought to extinguish the last Lenape claims to the Delaware River valley. In essence, the Pennsylvania alliance with the Six Nations helped to "simplify the transfer" of the Susquehanna and Delaware valleys to Pennsylvania. ${ }^{46}$ The Pennsylvania proprietors hoped that the strength of this political arrangement with the Six Nations would help the colony's economic and geographic expansion. ${ }^{47}$

Transfiguration: The Susquehannock Indians in the Seventeenth Century," Proceedings of the American Philosophical Society 112: 1 (Jan. 1968): 15-53; Webb, 1676, 381-391; Lustig, The Imperial Executive, 85-98.

${ }^{41}$ Kanickhungo to Thomas Penn and James Logan in Philadelphia, October 2, 1736, in MPCP 4: 82; Pennsylvania Archives, 1st series, 4: 83.

42 Jennings, "Delaware Interregnum," 184-185.

${ }^{43}$ Merrell, Into the American Woods, 36.

${ }^{44}$ Thomas Penn to an Iroquois delegation at the proposals for the Treaty of Friendship in Philadelphia, August 30, 1732, in MPCP 3: 449-450.

${ }^{45}$ Merrell, Into the American Woods, 36, 168; Francis Jennings, "Brother Miquon: Good Lord!" in Richard S. Dunn and Mary Maples Dunn, eds., The World of William Penn (Philadelphia: University of Pennsylvania Press, 1986), 206-207.

${ }^{46}$ Daniel K. Richter, The Ordeal of the Longhouse: The Peoples of the Iroquois League in the Era of European Colonization (Chapel Hill: University of North Carolina Press, 1992), 274.

${ }^{47}$ James H. Merrell, "Shickellamy, 'a Person of Consequence,' " in Robert S. Grumet, ed., Northeastern Indian Lives, 1632-1816 (Amherst: University of Massachusetts Press, 1996), 230-231. 
The Iroquois-Pennsylvania alliance challenged the Delawares and much of their rights to their homeland. In 1737, Thomas and John Penn, in concert with Logan, sanctioned the fraudulent "Walking Purchase." Delaware leaders had allegedly agreed in 1676 to acknowledge Pennsylvania's boundaries in the Delaware Valley by permitting provincial claims to extend as far as a man could walk in a day and a half. In a treacherous act, Pennsylvania officials had a path cut through the woods before the planned walk and hired three trained "fast walkers" to cover more ground than that of an average man. Delaware observers protested when these walkers covered sixty miles in one day and thus claimed most of the Lehigh Hills. The Forks leader Tishcohan accused Pennsylvania of duplicity: "You Run, thats not fair, you was to Walk." 48 Lappawinzo complained that the walkers did not "sit down to smoke," did not take the time to "shoot a squirrel, [and did nothing but] run, run, run all day long." ${ }^{49}$ The Delawares were forced to relinquish more land than intended.

Logan fomented much of the Delaware alienation. At the 1736 talks in Philadelphia, the Iroquois initially refused to claim Delaware lands because they feared that "they shoud doe anything amis to their [cousins]." ${ }^{50}$ The Iroquois clearly understood that they "laid no manner of Claim to the Lands on [the] Delaware River or on the Waters running into" that river. Logan, however, was adamant; he understood the importance of the Iroquois taking control of these lands from their tributaries. He hoped that the Six Nations would "Declare that they release to the Proprietors of Pennsylvania ... all [Lenape] Lands Between [the] Delaware and Susquehannah and as far to the north as the Blue Mts [Kittatinny Mountains]." 51

${ }^{48}$ Weslager, The Delaware Indians, 189; Richard C. Adams, The Delaware Indians: A Brief History (1906; reprint, Saugerties, New York: Hope Farm Press, 1995), 20. Richard Adams was a full blood Delaware who wrote on the history of his people in the early twentieth century. Also see Ted Morgan, Wilderness At Dawn: The Settling of the North American Continent (New York: Simon \& Schuster, 1993), 288-296; Merrell, Into the American Woods, 14, 16, 176, 292.

${ }^{49}$ Lappawinzo in William J. Buck, "Lappawinzo and Tishcohan: Chiefs of the Lenni Lenape," The Pennsylvania Magazine of History and Biography 7 (1883): 216.

${ }^{50}$ Iroquois leaders, Penn Manuscripts of Indian Affairs, Philadelphia: Historical Society of Pennsylvania, 1: 39 .

${ }^{51}$ James Logan to Conrad Weiser, August 18, 1736, Logan Papers, Philadelphia: Historical Society of Pennsylvania, 11:26; Jennings, "Delaware Interregnum," 185. This region from Easton up to the Delaware River, including the Lehigh Valley, and to the Kittatinny Mountains was again hotly contested. In 1759, the eastern Delaware chief named Teedyuscung, instigated by anti-proprietary Quakers, maintained that the Delawares had been cheated out of 
It was the proprietors who pressured the Six Nations to assert their authority over the Delawares. In 1738, Pennsylvania Lieutenant Governor George Thomas asked that the Iroquois "remove immediately ... those vile ones from the Forks of [the] Delaware." ${ }^{52}$ Logan wanted the Six Nations to "assume total suzerainty over all the Indians" in Pennsylvania, including the Delawares. ${ }^{53} \mathrm{He}$ believed the Delawares were "weak and too often knavish" and not worthy to strike a treaty on their own, without Iroquois supervision. ${ }^{54}$ Four principal Iroquois leaders cooperated with Logan by denying Delaware rights and ceding the forks of the Delaware to Pennsylvania. ${ }^{55}$ Most importantly, they told Logan and the Proprietors never to purchase lands from the Delawares, who were a "people of no virtue and have nowhere a fire burning and deal very often unjust with our friends and brethren the English." 56 Here the Iroquois were reminding Pennsylvania that the Delawares, without a central council, were impotent props of the League.

this tract of land. He demanded fair compensation. In June of 1759, the Board of Trade for the British Crown ordered Sir William Johnson, Superintendent of Indian Affairs for the Northern Department to settle the issue. Johnson met with Teedyuscung and other eastern Delawares in Easton during the summer of 1762 and confirmed that the Proprietors had not cheated the Delawares out of this land. Johnson suggested that the Pennsylvania government give the Delawares gifts (to be valued at two hundred British pounds) "as a Token of their friendship for them...." Teedyuscung and other Delawares agreed to renounce claim to this region and recognize Pennsylvania as the rightful owner. See the letter from Sir William Johnson to the Lords of Trade, Aug. 1, 1762 in James Sullivan, et al; eds., The Papers of Sir William Johnson, 14 vols. (Albany: State University of New York, 1921-1965), 3: 850-851.

${ }^{52}$ Lieutenant Governor George Thomas, in Boyd, ed., Indian Treaties by Benjamin Franklin, xxxi-xxxii, 31 .

${ }^{53}$ Jennings, "Delaware Interregnum," 181.

${ }^{54}$ Logan quoted in Jennings, "Delaware Indians in Covenant Chain," in Kraft, ed., Delaware Indian Symposium, 96.

${ }^{55}$ Wallace, Weiser, 75.

${ }^{56}$ Petition of Iroquois leaders to Thomas Penn, Nov. 19, 1737, in Boyd, ed., Indian Treaties by Benjamin Franklin, xxvii. For the most part, the Six Nations were more concerned about compensation for their claims to land on the Susquehanna and Shenandoah from the governments of Virginia and Maryland. It could be surmised that these Iroquois believed that if they cooperated with Logan regarding the removal of Delaware Indians, Logan might intercede on their behalf to help the Six Nations receive "just" compensation from Virginia and Maryland. Also see Jennings, "Delaware Interregnum," 185. Julian Boyd mentions that the Proprietors set aside 6,500 acres of land in the Delaware Forks for Lenape use until 1757. This tract was not cut up for survey until 1789. Regarding motives: Pennsylvania diligently pursued possession of the 
The metaphor of woman became further misinterpreted when the Pennsylvania government sought to remove the Delawares from the Delaware and Susquehanna River valleys to allow for white settlement. The obliging Six Nations of Iroquois now decided that a petticoat signified weakness rather than a peace-making ability once attributed to the Delawares. When the Onondaga orator Canasatego addressed the Delawares in 1742 that "We [the Iroquois] conquer'd you, we made Women of you," ${ }^{57}$ he was well aware that Pennsylvania officials were watching. Canasatego sought to elevate Iroquois status by denigrating the Delawares. The metaphor continued to lose its original meaning and through misinterpretation and manipulation became a title of derision. ${ }^{58}$

Despite the political posturing of Canasatego at the Philadelphia talks, he made a "peremptory Command the Delawares did not dare to disobey." He ordered them to leave the forks of the Delaware River and to move to the Shamokin and Wyoming valleys on the Susquehanna River in northeastern Pennsylvania where the Six Nations could "have you more under our eye." ${ }^{59}$ At Shamokin, on the forks of the Susquehanna River (modern Sunbury, Pennsylvania), the Six Nations had earlier in 1728 appointed the Oneida chief known as Shikellamy ("He Enlightens Us") to preside as vice regent over the bands of Delawares, Shawnees, and Iroquois in this multi-tribal town. ${ }^{60}$ By these actions, the Proprietors gave carte

Forks of the Delaware River to keep Connecticut squatters from the region. See Boyd, ed., Indian Treaties by Benjamin Franklin, xxviii.

${ }^{57}$ Canasatego to the Delawares, July 12, 1742, in Boyd, ed., Indian Treaties by Benjamin Franklin, 35-36.

${ }^{58}$ Also see Nancy Shoemaker, "An Alliance between Men: Gender Metaphors in Eighteenth-Century American Indian Diplomacy East of the Mississippi," Ethnohistory 42 (Spring 1999): 239-263. Shoemaker explores the manipulative functions of the metaphor used by the Iroquois and Delawares as a way to secure different diplomatic objectives.

${ }^{59}$ Charles Thomson, An Inquiry into the Causes of the Alienation of the Delaware and Shawnee Indians From the British Interests (1759; reprint, Philadelphia: John Campbell, 1867), 47; Canasatego to the Delawares, July 12, 1742, in Boyd, ed., Indian Treaties by Benjamin Franklin, 21-22.

${ }^{60}$ Fenton, Great Law and Longhouse, 399, 404, 424. Shamokin, because of its proximity to Philadelphia and trade and diplomatic activities became "the hub of the Pennsylvania Indian universe." Also see James H. Merrell, "Shamokin, 'the very seat of the Prince of darkness': Unsettling the Early American Frontier," in Andrew R. L. Cayton and Fredrika J. Teute, eds., Contact Points: American Frontiers from the Mohawk Valley to the Mississippi, 1750-1830 (Chapel Hill: University of North Carolina Press, 1998), 16-59. Sassoonan in Jennings, "Delaware Interregnum," 190. Shickellamy, an Iroquois, represented the interests of the Six 
blanche to the council at Onondaga regarding control of Pennsylvania's Indians. As Francis Jennings observes, "To the Delawares the Chain of Friendship was a rather unfriendly sort of chain." 61

The Six Nations-Pennsylvania alliance became "a blatant tool for provincial expansion." Delawares and Shawnees found themselves "trapped in an Iroquois-Pennsylvania vise." ${ }^{2}$ The Delawares, stripped of all titles to land as Pennsylvania sided with the land claims of the Six Nations, became outcasts in their own country. ${ }^{63}$ In this new Pennsylvania Indian policy, Delaware autonomy was suppressed and all their bargaining power was "made invalid" by Logan and the schism he created. ${ }^{64}$ The Iroquois enjoyed their exalted status. They boasted to Pennsylvania officials: "We are the Chief of all the Indians." ${ }^{65}$ The Six Nations reminded the Penn government that "their Cousins, the Delawares, have no lands to dispose of " and, in order to avoid future Walking Purchase controversies, "not to buy or accept of any Grants of Lands from them." ${ }^{66}$ This blatant injustice, aimed at the Delawares, would serve later as a rallying point in the formation of a Delaware nation.

While the Chain of Friendship aggravated a discontent among Penn's Indians and contributed in driving them from their homelands, other dynamics entered into the assault on the Delawares. The ramifications of colonial settlement: overcrowding, disease, lack of game, and the rum trade, became interwoven with the machinations of the political alliance of the Six Nations and Pennsylvania, to become the crucial factors that led to Delaware western migration.

In 1728, Pennsylvania officials permitted newly arrived German Palatines to settle in the Tulpehocken Valley, encroaching upon the homeland of the southern Unami groups of Delawares

Nations in Pennsylvania. He looked over Delaware affairs at the town of Shamokin. See Milton W. Hamilton, Sir William Johnson: Colonial American, 1715-1763 (Port Washington, New York: Kennikat National University Publications, 1976), 47-48.

${ }^{61}$ Jennings, "Delaware Indians in Covenant Chain" in Kraft, ed., Delaware Indian Symposium, 96-97; C. Hale Sipe, The Indian Chiefs of Pennsylvania (Butler, Pennsylvania: The Ziegler Printing Co., Inc., 1927), 122-133.

${ }^{62} \mathrm{McC}$ Connell, A Country Between, 57.

${ }^{63}$ Lawrence J. De Varo Jr., "Pennsylvania's Indian Policy With the Delawares 16821742" (Master's thesis, Duquesne University, 1966), 60.

${ }^{64}$ Ibid., 63.

${ }^{65}$ MPCP 4: 579-580. 
and pressuring them to sell this country. Sassoonan was shocked and said, "he could not himself believe the Christians had settled" in the place known as the "land of the Turtles." He had to see "with his own eyes ... the Houses and Fields they made there." 67

Brandywine Delawares suffered the same fate as Sassoonan's Schuylkill Indians. In 1729, Checochinican complained to the Pennsylvania council that his Delawares were being crowded out of their homes by German settlements. These intruders also disrupted the hunting and fishing of the Brandywine people. Checochinican, whose complaints fell upon deaf ears, lamented, "we are redused to great wants \& hardships not withstanding. . ." 68 Some Brandywines moved to uninhabited parts of the Upper Susquehanna. By 1732, those who remained in the Brandywine Valley departed to live at Paxtung (current day Harrisburg). Eventually the Brandywine Indians, subsumed by the other Delaware bands at Paxtung, lost their group identity. ${ }^{69}$

Delawares had to face a steady influx of new settlers, who entered into the Susquehanna country and contributed to the depletion of game. Conrad Weiser, the Pennsylvania agent to the Iroquois, noted that the Susquehanna Delawares were in a state of crisis. On a visit to a Delaware town on the north branch of the Susquehanna in March of 1737, Weiser witnessed the squalor found among these people as he was surrounded by "bony little children who crowded around with tears on their stolid faces." He could only offer these children a weak soup made of corn meal and ashes. Most of the people in the town, unable to find game, subsisted for weeks on maple juice and sugar water. ${ }^{70}$ A Delaware elder told Weiser that the Delawares had brought about the demise of animals when they over-hunted. He maintained that his people had become overly fond of alcohol and killed too many animals for their skins to trade for rum. The old man

${ }^{66}$ Iroquois message to Thomas Penn in council, Philadelphia, March 26, 1741, in ibid., 4: 481.

67 Sassoonan in council, Philadelphia, June 5, 1728, in MPCP 3: 332; Council meeting in Philadelphia, August 24, 1728, in MPCP 3: 327-328. By 1732, many of Sassoonan's people had relocated to the Upper Susquehanna community at Shamokin. See Merrell, Into the American Woods, 166, 177: Weslager, The Delaware Indians, 184-185.

${ }^{68}$ Checochinican to Lt. Gov. Gordon in Philadelphia, June 24, 1729, in Pennsylvania Archives, 1st series, 1: 239-240.

${ }^{69}$ Weslager, The Delaware Indians, 187; Goddard, "Delaware" in Trigger, ed., Handbook of North American Indians, 222.

${ }^{70}$ Conrad Weiser, March 28, 1737, in Wallace, Weiser, 84. Also see Sugrue, "Peopling and Depeopling of Early Pennsylvania," 29-30. 
believed that the Great Spirit had "driven the wild animals out of the country," would not bring them back until the Delawares "cease from [their] sins" and shun "strong liquors." 71

The rum trade was as disruptive as were the intrusions of white settlers. Sassoonan complained that "ill People amongst the Christians" were bringing too much rum into the Delaware towns, resulting in violence and "Mischief." He urged Pennsylvania Governor Patrick Gordon to regulate the rum trade and keep the traders from entering Shamokin. ${ }^{72}$ Two members of the Pennsylvania Assembly warned that if the rum trade were not controlled, "some fatal Quarrel with the Indians" would result. They condemned the traders who entered Delaware and Shawnee communities in the Susquehanna Valley and brought "Spirituous Liquors amongst them, their Cheating of them of their Skins and Wampum, and Debauching their Wives. ..."73

In search of food and weary of colonial settlement, bands of Delawares (mostly southern Unami) and Shawnees increasingly hunted and lived west of the Allegheny Mountains. This gradual move to the hunting camps in the western reaches of the Allegheny and Ohio had started as early as the 1720s. Shawnees, who were anti-British and who lived close to Lenape towns in the Lebanon and Delaware valleys, instigated bands of Delawares to move with them west, out of the reach of increasing Iroquois dominance and the rush of Anglo settlers. The Six Nations

71 A Delaware Indian to Weiser, April 3, 1737, in William M. Beauchamp, ed., The Life of Conrad Weiser, As It Relates to His Services as Official Interpreter between New York and Pennsylvania and as Envoy between Philadelphia and the Onondaga Councils (Syracuse, New York: The Onondaga Historical Association, 1925), 21-22. Many Algonquian speakers rationalized that game became scarce as a result of improper behavior among Indian people. They believed that if they treated animals with disrespect, the Great Power would chase away the animals or the animals themselves would avoid the hunters. For an interesting study of the metaphysical relationship between Indian hunters and game animals see Calvin Martin, Keepers of the Game: Indian-Animal Relationships and the Fur Trade (Berkeley: University of California Press, 1978). Martin believes that the Indians broke the spiritual nexus with animals and thus played a vital role in the demise of game in North America. For a counter-view to Martin's assertions see Shepard Krech III, ed., Indians, Animals, and the Fur Trade: A Critique of "Keepers of the Game" (Athens: University of Georgia Press, 1981).

72 Interpreters conveying Sassoonan's message to Lt. Gov. Gordon in Philadelphia, August 13, 1731, in MPCP 3: 403-404.

73 Pennsylvania assemblymen, William Till and Abraham Taylor to Governor George Thomas in Philadelphia, August 11, 1744, in MPCP 4: 740-741. 
dismissed these Ohio Indians as "mere hunters" and not important in the greater scope of Iroquois affairs. ${ }^{74}$

In 1725, the Turtle and Turkey tribes of Delawares led by Shannopin established a principal town on the banks of the Allegheny River and called it Kittanning ("at the Big River"). ${ }^{75}$ In two separate land dealings arranged in 1731 and 1732, the Penns purchased the rest of the lands belonging to "Sassoonan ... Sachem of the Schuylkil Indians." Delawares of the Turtle totem, without the consent of either Sassoonan or Pennsylvania officials, eventually relocated to western Pennsylvania. ${ }^{76}$ Others remained in the east and moved with Sassoonan, the ancient figurehead King of the Delawares, to Shamokin. However, many more Delaware Indians escaped the demographic pressures and uncertainty of the east and migrated to the west. ${ }^{77}$

The "migratory stream" of Delawares and Shawnees "accelerated rapidly" after the late 1720s; by 1731, an estimated 400 to 500 Indians moved into the Allegheny and Ohio regions and established communities such as Kiskimineta's Town, Shannopin's Town, Frankstown, Tioga, and Pymatuning--all of which stabilized the new cultural environment of migrant Indians and both Anglo and French traders. ${ }^{78}$ Thomas Penn and Governor Gordon became alarmed that French traders in the Ohio were seeking to win over the Pennsylvania tribes. Pennsylvania officials, through the intercession of the Six Nations, sent messages to Shawnees and Delawares in the west. A Seneca leader named Tyoninhogarao told the old Shawnee chief Kakowatchy that his people "should not look to Ohio, but turn his face to us [the Six Nations]," who "never intended to hurt the Shawanese." He then sent a message to Sassoonan and reminded him that his

74 Iroquois leader in McConnell, A Country Between, 135; Frederick M. McCullough, "The Efforts of Pennsylvania to Extend Her Influence Over the Indian Tribes in the Western Region of the Province, 1748-1758" (Master's thesis, Duquesne University, 1964), 12; Merrell, Into the American Woods, 204-205.

${ }^{75}$ C. Hale Sipe, The Indian Wars of Pennsylvania (1931; reprint, Lewisburg, Pennsylvania: Wennawoods Publishing, 1995), 42-43; McConnell, A Country Between, 225; Hinderaker, Elusive Empires, 27-28; Hunter, "Subdivisions of the Delaware Indians," 32.

76 Pennsylvania Archives, 1 st series, 1: 344-345; Weslager, The Delaware Indians, 200201.

${ }^{77}$ Goddard, "Delaware" in Trigger ed., Handbook of North American Indians, 222.

${ }^{78}$ Hinderaker, Elusive Empires, 27-28. 
Delawares "must all come back from Ohio, for they should not settle there. ..." 79 Penn later met with Delaware and Shawnee leaders in Philadelphia and asked them why "they should retire such a distance from us. ..." They told him that the "place where they are now Settled [suits] them much better than to live nearer" to the government in Philadelphia. They concluded that they could live much better in the west than "any where on the Susquehannah." ${ }^{80}$ To alleviate the concerns of Penn and Gordon that the Ohio Indians would fall under the influence of the French, they warned Opakethwa and Opakeita of the Shawnees that "while the French [were] civil to them . . . they [the Indians] must not prefer any other People to the English ... their true friends." ${ }^{81}$ This reminder by Pennsylvania officials did not deter the Shawnees from remaining in the Ohio and moving closer to the friendship of the French. Many Delawares, assessing their reduction in importance to the Penn government, were quick to follow the Shawnees.

By the early 1740s, most Forks and Munsee Delawares moved with bands of Shawnees to the north and west branches of the Susquehanna, where they remained until the end of the Seven Years' War. After that time, the northern Unami and Munsee Delawares moved into the Allegheny Valley of northwestern Pennsylvania. Other Delaware bands migrated from the Wyoming Valley to the Ohio. On the Ohio River, north of the three rivers, Delawares established the principal multi-tribal diplomatic and trade center of Logstown (modern-day Ambridge, Pennsylvania). ${ }^{82}$

In 1742, the Wolf and Turkey tribes established a cluster of four towns in the Beaver Valley (from current-day New Castle, Pennsylvania, to the west along the Mahoning River) known as Kuskuskies. The Kuskuskies eventually became the political focus of Delaware military and political activity in the west. ${ }^{83}$ In these towns, Indians and British traders from

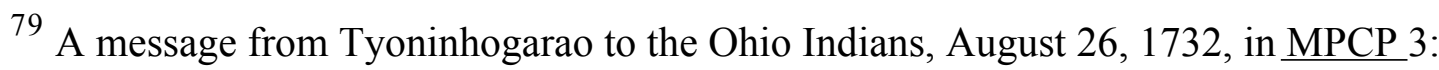
442-443.

${ }^{80}$ Delawares and Shawnees in a series of councils with Penn and Gordon in Philadelphia, August through October 1732, in MPCP 3: 462-463.

${ }^{81}$ Penn and Gordon to Opakethwa and Opakeita of the Shawnees, Philadelphia, September 30, 1732, in ibid., 3: 459.

${ }^{82}$ Hinderaker, Elusive Empires, 126-128; Goddard, "Delaware" in Trigger ed., Handbook of North American Indians, 222.

${ }^{83}$ Michael N. McConnell, "Kuskusky Towns and Early Western Pennsylvania Indian History, 1748-1778," The Pennsylvania Magazine of History and Biography 116 (Jan. 1992): 33-58; Sipe, Indian Wars of Pennsylvania, 372-373. 
Pennsylvania "bartered merchandise, swapped information, and forged personal alliances that promoted both business and a sense of common interests," all of which helped to build a "new regional identity." ${ }^{84}$ Much of this identity revolved around Delaware migrants being immersed in a region that allowed for both independence and a new sense of political-economic empowerment. Their ethnic identity intensified as other migrant Indian nations moved in, seeking the same kind of new start as the incoming Delawares. The polyglot environment of peoples in the Ohio did not water down Delaware ethnic and political similarities. Rather, gradually as more Lenapes and Munsees entered into the Ohio, a stronger sense of commonality was enhanced among the western Delawares.

Indicative of the mix of the Ohio country were the multi-national Indian towns, such as Logstown. The Delawares shared Logstown with Shawnees and bands of western Senecas and Cayugas, who as transplanted Indians to the Ohio became known as Mingos. ${ }^{85}$ In 1733, a "very great sickness [probably smallpox] amongst the Six Nations" ${ }^{86}$ drove bands of Senecas and Cayugas west into the hunting grounds of the Upper Ohio. In 1741, more groups of Senecas moved into the Ohio to escape a life-threatening drought and poor corn harvests. These Senecas settled at the junction of the Mahoning and Shenango rivers and named the town Kuskuski. ${ }^{87}$

Despite the potential for ethnic blurring, western Delawares embraced the Ohio country and all it offered. The Ohio region reinforced their push for freedom from the Proprietors of Philadelphia, the council fires at Onondaga, and the territorial intrusions of Anglo settlers. This political self-sufficiency could only be supported by the Ohio country itself--a country rich in game and with access to both the rivers and Euramerican traders. These factors were crucial for Delaware independence and eventual nationhood.

${ }^{84}$ Michael N. McConnell, "Peoples 'In Between': The Iroquois and the Ohio Indians, 1720-1768," in Daniel K. Richter and James H. Merrell, eds., Beyond the Covenant Chain: The Iroquois and Their Neighbors in Indian North America, 1600-1800 (Syracuse, New York: Syracuse University Press, 1987), 97.

${ }^{85}$ Richter, Ordeal of the Longhouse, 256-257; McConnell, A Country Between, 61, 6769.

${ }^{86}$ The Seneca orator Hetaquantagechty as interpreted by Conrad Weiser to Thomas Penn and Patrick Gordon in Philadelphia, August 16, 1733, in MPCP 3: 512.

${ }^{87}$ Ibid., 5: 357-358. Not to be confused with the Delaware towns located in Lawrence County called Kuskuskies. The Seneca town preceded the Delaware cluster of towns. See Sipe, Indian Wars of Pennsylvania, 372-373. 
Delawares entered this new territory as "pioneering newcomers" rather than invaders. The Ohio was once a game-rich haven for such tribes as the Eries, Monongahelas, Mahonings, and Akanseas. This region became a "no-man's-land" when the Iroquois devastated or scattered these tribes during the Beaver Wars of the $1670 \mathrm{~s}$ and $1680 \mathrm{~s} .{ }^{88}$ After this period, western Pennsylvania and the Ohio country "was altogether deserted, and free for any People to enter upon. ..." 89

Not all Pennsylvania Indians were willing to leave their homelands to seek a better life in the Ohio. Delawares who adhered to the dictates of Onondaga and remained in the east gradually witnessed the destruction of their social world and autonomy. They were called "tame" or "settlement" Indians to differentiate them from the frontier Delawares--the "remote or wild" natives. Peaceful Delawares who remained at their traditional lands on the Forks of the Delaware River "were tiny islands in an alien, forbidding sea" of white settlements. ${ }^{90}$ Other groups, mostly Munsees, were scattered to Ulster and Orange counties in New York. Munsee-Delawares who remained in settlements at Crosswicks, Coaxen, and the mission town of Cranbury in New Jersey had their land relinquished by that colony in 1758. By 1747 many of the Delawares had relocated in the Ohio country, while those who remained in the east were slowly absorbed into the multiethnic communities of Quakers, Germans, Welsh, Moravians, Scots-Irish, and free blacks of the Susquehanna and Delaware valleys. ${ }^{91}$ The main opponent of the Walking Purchase, Nutimus, moved to a Shawnee village on the north branch of the Susquehanna called Nescopeck with his family. He too became subsumed into the ethnic mix of peoples as he maintained an English-style farm aided by five black slaves. ${ }^{92}$

Although temporarily distant from white settlement, it was a harrowing time for those Delawares who moved west from their eastern homes. Joseph Peepy (Weholelahund), a

${ }^{88}$ McConnell, A Country Between, 9; Sipe, Indian Chiefs of Pennsylvania, 44.

${ }^{89}$ Conrad Weiser, on behalf of Virginia commissioners, to leaders of the Six Nations in Lancaster, Pennsylvania, June 28, 1744, in MPCP 4: 717.

${ }^{90}$ Merrell, Into the American Woods, 88. Also see Wallace, Teedyuscung, 67-68; Becker, "Boundary Between the Lenape and the Munsee," 13-14.

${ }^{91}$ Champagne, "Delaware Revitalization Movement," 110-111; Becker, "Boundary Between Lenape and Munsee," 13; Hinderaker, Elusive Empires, 129.

${ }^{92}$ Hinderaker, Elusive Empires, 129. 
Delaware who became a Presbyterian convert, lamented on the plight of his people as migrants to the Ohio Valley:

Our fathers told us, how numerous the Indians were in their days, $\&$ in the days of their fathers. Great towns of Indians were all along the sea shore, and on the rivers, and now you, if you travel through that country, you will scarcely see an Indian; but you will see great and flourishing towns of white people who possess the land of our fathers, and we are cut off, and fall back upon these distant rivers, and we are reduced to a small number. ${ }^{93}$

This migration can also be seen as both a desired relocation and a tragic diaspora. As Delawares crossed the Alleghenies, they approached this westward movement as "Kwulakan." This term had a double meaning, for it pertained to the need of Lenapes to move from their traditional homes when this environment became corrupted and tainted by white settlement. With the scarcity of game becoming a reality and Iroquois dominance becoming intolerable, Delawares migrated to a new country that offered the potential for peace, harmony, and bounty. Kwulakan became an ideological mechanism to escape disaster. Delawares also believed that Kwulakan referred to a threshold that, when crossed, would rouse the deities to take pity and intervene in tribal matters by showing benevolence to the Delawares. ${ }^{94}$

The richness of the Ohio offered such an opportunity for eastern native migrants. Marquis de la Galissoneire, the Governor of Canada noted that the "Delawares left their eastern Pennsylvania" homes for "want of Game and Korn and removed to Allegheny ... a Fine Country watered by the branches of the Miamis, Scioto, and Muskingum Rivers." 95

93 Joseph Peepy in Russell Booth ed., The Tuscarawas Valley in Indian Days: 17501797 (Cambridge, Ohio: Gomber House Press, 1994), 124.

94 Jay Miller, "Kwulakan: The Delaware Side of Their Movement West," Pennsylvania Archaeologist 45 (1975): 45-46. This is strictly an anthropological and not a historical perspective forwarded by the Lenape scholar Jay Miller.

95 Memoirs of the Marquis de la Galissoneire, December 1750, in Stevens and Kent, eds., Wilderness Chronicles, 29. 
Despite their alienation from the Pennsylvania Proprietors, the Delawares were not "weakling women," dominated by the Iroquois. ${ }^{96}$ Eastern Delawares, who remained in the Wyoming Valley and Upper Susquehanna under the supervision of Iroquois vice-regents such as Shikellamy, simply chose not to migrate westward with the other Delaware groups. ${ }^{97}$ To remain in their eastern homelands, these Delawares had to accept Iroquois and English pretensions of subjugation. $^{98}$

An ethos of imperial prominence, though acknowledged by the Iroquois, was only partly accepted by the Delawares and Shawnees who moved out of the grasp of Onondaga and Philadelphia. Ohio Indians saw the Six Nations as agents of British Indian policy. By acknowledging Iroquois preeminence in Anglo-Indian relationships, the western Delawares and other Ohio Indians believed that they were assured of British trade goods and, if needed, British military protection. While eastern Delawares remained under Iroquois supervision, westernmigrating Delawares accepted Iroquois supremacy only on a metaphorical level; necessary to stay on good diplomatic terms with the Six Nations and most importantly, with the British.

The Delawares, however, were reborn in the west. Delaware clans and bands remained intact as they moved beyond the Alleghenies. ${ }^{99}$ Their totem tribal identities of Turtle, Wolf, and Turkey became more pronounced in terms of specific political-ethnic identities. These identities became contributing factors in the concept of Delaware nationhood.

Pennsylvania officials, at this time, haphazardly referred to the Delaware, Shawnee, and Mingo bands in the Ohio collectively as "Indians on the Allegheny." ${ }^{100}$ In the Allegheny region, the various tribes each established their own core towns. The Delawares of the Allegheny were

${ }^{96}$ Jennings, Ambiguous Iroquois Empire, 214-215.

${ }^{97}$ According to the Indian interpreter Conrad Weiser, eastern Delawares retained a degree of independence. They rejected commands from the Six Nations to move closer to them by relocating up the Susquehanna. Weiser to Thomas Lee, July 5, 1746, mss., 1:15, Correspondence of Conrad Weiser, Philadelphia: Historical Society of Pennsylvania.

${ }^{98}$ Richard Aquila, The Iroquois Restoration: Iroquois Diplomacy on the Colonial Frontier, 1701-1754 (1983; reprint, Lincoln: University of Nebraska Press, 1997), 10. Richard Aquila concludes that with regard to the Iroquois hegemony: "Although the Iroquois empire may have been a myth, that myth influenced reality."

${ }^{99}$ Malcolm B. Brown, “" Is It Not Our Land? ': An Ethnohistory of the SusquehannaOhio Indian Alliance" (Ph.D. diss, Oklahoma State University, 1996), 178.

${ }^{100}$ Pennsylvania officials, Philadelphia, May 27, 1730, in Pennsylvania Archives, 1st series, 1: 262-263. 
found mostly at Kittanning on the Ohio. There, over one hundred and fifty Turtle and Turkey Delawares under the leadership of Shannopin and Captain Hill (Merhegoakehuk) resided. These leaders identified themselves on wampum belts sent to Philadelphia as "Chieffs of ye Delawares att Alleegaeening." 101

Kittanning Delawares were quick to identify themselves as separate from other Ohio Indians, as were most Delawares who migrated into the Ohio. One specific colonial document is exemplary of this strong affinity the Delawares had towards phratry socio-political expression. And yet there was a hint of a nationalistic attitude among the western Delawares. In August of 1732, seven Delaware chiefs living in Allegheny country respectfully declined to meet with Governor Patrick Gordon. They could not travel "att Such a far Distance" and were preparing for hunting season. ${ }^{102}$ The bottom of their letter, declining a visit to Philadelphia, contained a pictographic drawing of the three phratries--Turtle, Turkey, and Wolf. The Turtle column included the signatures of Captain Hill, Shannopin, Allemykoppy (this was Sassoonan), and Ohahmondamaw, while under the pictograph of the Turkey were the X marks of Quoowahoune, Oppohwhyeckun, and Queekoikahwin. Most interestingly, there is a line drawn across the Wolf emblem. The Wolf tribe, though considered part of the Delawares, failed to place a mark on this document (possibly because of distance; the Munsee-Wolf group at this time lived on the northern and western branches of the Susquehanna). ${ }^{103}$ The pictographic drawing that accompanied the note revealed a great deal about the western Delawares. Despite the lack of a

${ }^{101}$ Delaware chiefs, April 30, 1730, in ibid., 1: 262-263. For other references made to "ye Delaware Indians att Allegheny," see Pennsylvania Archives, 1st series, 1: 299-300. A few Shawnees lived with the Delawares at Kittanning. The majority of Shawnees resided north on the Ohio River at Sewickely's Town. See Pennsylvania Archives, 1st series, 1: 549-550.

${ }^{102}$ Delaware chiefs to Governor Gordon, Allegheny, August 8, 1732, in ibid., 1: 341.

${ }^{103}$ Drawing of phratry symbols and list of signatures entitled "chiefs of the Delaware Indians at Allegaeening," Society Miscellaneous Collection, Indians 1732, Box 11c, Philadelphia: Historical Society of Pennsylvania. Also see Melburn D. Thurman, "The Delaware Indians: A Study in Ethnohistory" (Ph.D. diss., University of California at Santa Barbara, 1973), 90. According to William W. Newcomb, Munsee Delawares, who lived in the Upper Allegheny Valley, were autonomous with regard to the Turtle and Turkey Delaware tribes living in the Beaver Valley of the Ohio. See William W. Newcomb, Jr., The Culture and Acculturation of the Delaware Indians (Ann Arbor: Anthropological Paper no. 10 of the Museum of Anthropology, University of Michigan, 1956), 50-53, 125, 175. 
Wolf signature, it was the first time in an official document that the three animal tribes appeared together as distinctive components of what could be construed as a Delaware nation.

The western movement slowly increased Delaware ethnic and political identity but at the expense of the Six Nations and Pennsylvania. An Iroquois spokesman noted that the Susquehanna Delawares were always on the move and asked them to "remain where you are, and not abandon your village." He requested that Delawares living on the forks of the Ohio, to move to the Upper Allegheny towns of Kuskuskies where they could be better supervised by the Six Nations. After much deliberation, the Turkey and Turtle tribes refused to leave the Ohio. ${ }^{104}$ In 1737, Logan lamented to Lieutenant Governor George Clarke of New York that "the most of our Delaware Indians" have been "drawn off to the branches of Ohio for the Conveniency of game." ${ }^{105}$ He failed to acknowledge Pennsylvania's anti-Delaware policy as a contributing factor in this move.

Increasing French presence in the Ohio and a weakened provincial economy, caused by fewer Indians to provide fur pelts, altered the attitude of Pennsylvania. Officials from Philadelphia now admitted they had erred in their treatment of the Shawnees and Delawares, which incited them to move across the Alleghenies. ${ }^{106}$ Another difficulty arose when the Six Nations, aware of social disruptions in Indian villages because of the rum trade, asked Pennsylvania to recall its traders from the Ohio, Allegheny, and Susquehanna. In response, Pennsylvania made futile demands that the Iroquois recall their "tributaries" from the Ohio and resettle them on the western branch of the Susquehanna. They rationalized, "the [Ohio] Indians cannot live without being supplied with our Goods: They must have Powder and Lead to hunt, and Cloaths to keep them warm; if our People do not carry them, others will, from Maryland, Virginia, Jersey, or other Places.” 107 These demands fell upon deaf ears--western Delawares did

104 An Iroquois spokesman, in Stevens and Kent, eds., Wilderness Chronicles, 138.

${ }^{105}$ Logan to Lt. Gov. Clarke, Aug. 4, 1737, in Logan Papers, Philadelphia: American Philosophical Society, 4: 7-8.

${ }^{106}$ Proprietary officials to the Six Nations in Philadelphia on Oct. 13, 1736, in Boyd, ed., Indian Treaties by Benjamin Franklin, 10-11.

${ }^{107}$ Pennsylvania Officials to the Six Nations in Philadelphia on Oct. 13, 1736, in ibid., 11. 
not budge. The Ohio Delawares had "placed themselves well beyond the grasp" of the Covenant Chain of Pennsylvania and the Six Nations. ${ }^{108}$

Richard Peters, the Provincial Secretary noted in 1750 that "many Indians [Senecas and Cayugas] have left their towns among the Six Nations and gone and settled to the westward of the branches of the Ohio." He warned Proprietor Thomas Penn that the Ohio tribes, including the Delawares, made a "formidable body, not less than fifteen hundred" that kept in "appearance a sort of dependency on the Council at Onondaga" but for the most part were merely humoring the Six Nations. 109

While the Delawares and other Ohio Indians were quite aware of "their strength," 110 they also recognized their responsibilities to preserve the "Chain bright" and to keep diplomatic relations with the Six Nations. ${ }^{111}$ The Ohio Indians were in a quandary. They became alarmed at the increasing strength of the French and their Indian allies to the west and the Great Lakes. While the Ohio Indians saw the Iroquois as representatives of British policy; not dreaded conquerors, they were disillusioned with the neutral stance of the leaders of the Six Nations. Not content to listen to the "old men at Onondaga," the Ohio Indians appealed to the British to furnish them with "better Weapons, such as will knock the French down." 112 They desired to "kindle a [council] fire" in the Ohio and to invite "all the Indians at a considerable distance" to come and unify as a body of warriors. ${ }^{113}$

The young warriors of the Ohio were energetic and bold, willing to fight to maintain their territorial rights to this region. It was necessary to gain British support, and to do so they had to deal with the Six Nations and their pretensions as conquerors and overlords of this region. Western Delawares were aware that to remain within the British sphere, they needed to show deference to Onondaga in certain matters without sacrificing too much integrity.

108 McConnell, A Country Between, 135.

${ }^{109}$ Richard Peters in Nicholas B. Wainwright, George Croghan: Wilderness Diplomat (Chapel Hill: University of North Carolina Press, 1959), 40-41. For a strong analysis of waning Iroquois influence among Ohio tribes see McConnell, "Peoples 'In Between,' " in Richter and Merrell, eds., Beyond the Covenant Chain, 93-112.

110 Peters, in Wainwright, George Croghan, 41.

111 Unidentified Ohio Indian in council at Philadelphia, Nov. 15, 1747, in MPCP 5: 146. 112 Ibid., 147. 
Eventually attitudes of those principal men in Philadelphia and Onondaga, who treated western Delawares as malcontents in the Covenant Chain, changed. This change occurred when geopolitical realities, including the struggle for imperial dominance between England and France and shifts in the Anglo-Indian diplomatic focus from Iroquoia to western Pennsylvania, brought western Delawares and the Ohio Indians to center stage in North America.

113 Mingo delegation to Pennsylvania officials, Philadelphia Nov. 15, 1747, in Boyd, ed., Indian Treaties by Benjamin Franklin, 103-104. 


\section{Chapter II}

\section{"They assumed a tone of defiance": The Ascension of the Western Delawares, 1750-1756}

Francis Parkman noted that Delaware Indian movement westward to the Ohio country helped to free these Indians as tributaries of the Iroquois Confederacy and gave them a confidence which they had lacked since being driven from their traditional homelands in the Delaware River watershed. In typical Parkman fashion, garnished with drama and romance, he wrote "Dwelling under the shadow of the tyrannical Confederacy, they [the Delawares] were long unable to wipe out the blot; but at length, pushed from their ancient seats by the encroachments of white men, and removed westward, partially beyond the reach of their conquerors, their native spirit began to revive, and they assumed a tone of defiance."1

Parkman's observations, though true, were highly exaggerated and void of an understanding of historical processes as it pertained to the Delawares. Their westward migration initiated the push for unity and self-determination. It also opened up new possibilities regarding political organization. These goals were intertwined and attained very slowly and cautiously, with regard to their relations with Pennsylvania, the Six Nations, and most importantly, the British. The western bands of Delawares especially had to contend with the meddling from Onondaga that seemed to follow them across the Allegheny Mountains.

The geopolitical environment of western Pennsylvania and the Ohio River Valley before and during the French and Indian War served as a spawning ground for Delaware militancy, which in turn increased their assertion of independence and contributed to a greater centralization of Delaware tribes. The Delaware tribes living in Ohio country had entered into a perfect situation of realpolitiks--a no-lose situation which, temporarily at least, helped to resurrect these Indians as a political and military power. Their migration to the west helped reduce the political slight suffered by the Delawares as a result of the Treaty of Friendship between Pennsylvania and the Iroquois Confederation.

At the onset of the Seven Years' War, most of the Delawares had moved west to reassert a tribal political independence with only minimal Iroquois interference. During the early 1750s,

${ }^{1}$ Francis Parkman, The Conspiracy of Pontiac (1851; reprint, New York: The Library of America, 1991), 380. 
they rebelled against the Six Nations when the confederation sought to select a Delaware leader who would be compliant with the governments at Onondaga and Philadelphia. Also, seeking vengeance for their political emasculation at the hands of Logan and the Proprietors, the Delawares, in a brutal fashion, rebelled against Pennsylvania. Despite these actions of rebellion, western Delawares did not desire to sever their relations with the British. They sought to establish both national unity and autonomy for themselves, without destroying a more beneficial and necessary diplomatic relationship with the British.

To maintain positive relations with the British, western Delawares, as supposed tributaries of the Iroquois League, still acknowledged their responsibilities and limitations within the Covenant Chain. They only rejected certain uncomfortable intrusions by the Iroquois. One of these encroachments concerned the selection of a headman for all Delawares, east and west, who would be acceptable to the Six Nations, Pennsylvania, and most importantly, the Delawares themselves.

From a historical perspective, Delawares were "drawn into diplomatic relations with Pennsylvania," which required certain adaptations. Despite the lack of centralization among the Delaware tribes, English colonial officials in general insisted upon negotiating with a specific Indian leader. Eventually they propped up certain people and empowered them to speak for all Delawares. ${ }^{2}$ From 1683 to 1697, William Penn recognized Tamanend of the Turtle tribe as the principal leader of Unami Delaware speakers. ${ }^{3}$ By 1715, Sassoonan had inherited much of Tamenend's authority and was recognized by Pennsylvania as chief spokesman of the Delawares. He attained and maintained a positive relationship with Pennsylvania governors. Despite his struggles with blindness and alcoholism (Conrad Weiser claimed that Sassoonan had "lost his Senses and [was] uncapable of doing anything") in his later years, Sassoonan held onto this title until his death in 1747 at Shamokin. ${ }^{4}$

${ }^{2}$ Hinderaker, Elusive Empires, 74.

3 Myers, ed., William Penn's Own Account of Delaware Indians, 24-25; Sipe, Indian Wars of Pennsylvania, 57. Tamanend, also spelled as Tamanen, Tamanee, and Taminent lived in the current day Bucks County region. The Tammany Society of New York (a Democratic organization established in 1798 to counteract the elite-based Federalists and Society of Cincinnati) was named after this Delaware leader. The date of Tamanend's death has been estimated from 1698-1701. See Weslager, The Delaware Indians, 168.

${ }^{4}$ Conrad Weiser, Berks County, June 20, 1747, in Sipe, Indian Chiefs of Pennsylvania, 101. Sassoonan was related to Tamanend. Delawares were matrilineal--there was a royal line of 
This Schuylkill leader, honored in the east, did not have the same clout among Delawares who had migrated to the west. As Sassoonan sought diplomatic solutions with Pennsylvania leaders, western Delawares saw this as appeasement and accommodation. Delaware leaders at Kittanning and Logstown ignored Sassoonan's continuous overtures for them to bring back their people to the Susquehanna. 5

In the waning years of Sassoonan's leadership, the Pennsylvania-Six Nations alliance intervened in the political affairs of the Delawares. Pennsylvania Governor James Hamilton hoped that with the demise of Sassoonan, the Delawares would be prepared to name a new headman, suitable to all Indian and colonial parties. ${ }^{6}$ Delawares, in other words, had to meet with the alliance's stringent standards for an accommodating leader.

In 1741, the Iroquois vice-regent Shickellamy and Pennsylvania's Secretary James Logan rejected the selection of Pisquetomen by Sassoonan to be his future replacement as the principal man of the Delawares. Pisquetomen, who formerly lived at Shamokin, was strongly opposed to the Walking Purchase. He was the nephew of Sassoonan and the eldest brother of the prominent leaders of the Turkey tribe named Shingas ("Wet Marshy Ground") and Tamaqua (King Beaver). All three in this "royal family" moved to the Ohio and lived at Kittanning--a town slowly becoming the center of coalescence for Unami-speakers of the Turtle and Turkey phratries living in the west. Delawares regarded Pisquetomen "high in authority among the Delawares in the West." Sassoonan believed him a perfect choice to be "the person who is to have the chief command and to be the mouth of his [Delaware] people." 7

succession, all from the female's side of the family, regarding the selection of chiefs. The sons of a chief did not inherit rank. The successor was usually a brother of the chief, the son of a sister, or the son of a sister's daughter. Succession was "always of the Mother's side." See William Penn's comments in Albert Cook Myers, ed., Narratives of Early Pennsylvania, West New Jersey, and Delaware, 1630-1707 (New York: Charles Scribner's Sons, 1912), 234-235; Weslager, The Delaware Indians, 64-65. With regard to the description of a debilitated Sassoonan see Conrad Weiser in council at Philadelphia, July 9, 1747, in MPCP 5: 88.

${ }^{5}$ Conrad Weiser in council at Philadelphia, July 9, 1747, in MPCP 5: 88.

${ }^{6}$ Governor James Hamilton to George Croghan and Andrew Montour, Feb., 7, 1750, in Pennsylvania Archives, George Reed, ed., 4th Series, 12 vols. (Harrisburg: The State of Pennsylvania Printer, 1900), 2: 146-147.

7 Timothy Alden, ed., "An Account of the Captivity of Hugh Gibson among the Delaware Indians of the Big Beaver and Muskingum from the Latter Part of July 1756 to the Beginning of April, 1759," Collections of the Massachusetts Historical Society, 3rd series, (1837), 6: 142-143; Sassoonan in Jennings, "Delaware Interregnum," 190; Wallace, "Women, 
Pisquetomen was also a Delaware leader who could unify the Delawares, both east and west. His experiences were indicative of what the Delawares were facing in Pennsylvania. He had experienced displacement, when his people were forced from the Tulpehocken Valley in 1732, and yet tasted a sense of freedom and independence when he moved his followers west into Kittanning town. Logan saw Pisquetomen as an obstructionist to Pennsylvania's political agenda, which favored a powerful Iroquois hegemony on the frontier. ${ }^{8}$ Pisquetomen was not a likely pliable figurehead who would help the Six Nations in their attempted control of the Delawares. Most importantly, both Pennsylvania and the Six Nations saw Pisquetomen as a dynamic leader who epitomized the increasingly obstinate and independent nature of western Delawares and a man who could influence eastern Delawares to take a similar stance of defiance. Logan, who wanted a leader with the weight and the determination to recall all Ohio Delawares back to the Susquehanna region, quickly saw that Pisquetomen lacked the will to bring the Delawares back, as much as Sassoonan had lacked the authority to command Delawares back to the Susquehanna. ${ }^{9}$

Pisquetomen's rejection did not sit well with many western Delawares. They refused to accept a puppet chief assigned by Onondaga and Philadelphia. ${ }^{10}$ Logan, Shickellamy, and Indian agent Conrad Weiser worked hard to block Pisquetomen's appointment. ${ }^{11}$ Within a month of Sassoonan's death in September of 1747, Weiser considered Lappapitton "to be the fittest" in terms of a successor to Sassoonan. Lappapitton, out of respect for Pisquetomen, declined the offer. $^{12}$

Land, and Society," 14-15; Newcomb, "Culture and Acculturation," 85; Goddard, "Delaware" in Trigger, ed., Handbook of North American Indians, 222-223. On the relationship between Shickellamy and James Logan see Hamilton, Sir William Johnson, 47. Kittanning was a chief Delaware town located along the Allegheny River, fifty miles from Fort Duquesne. It served as a rendezvous point for Delaware and Shawnee warriors and as a depot to hold white captives. See Sipe, Indian Wars of Pennsylvania, 42-43, 313-317.

${ }^{8}$ Weslager, The Delaware Indians, 209; Schonenberger, Lenape Women and the Colonial Encounter, 246-247.

${ }^{9}$ Weslager, The Delaware Indians, 246.

10 Jennings, "Delaware Interregnum,"190.

${ }^{11}$ Pennsylvania Archives, 1st Series, 1:762.

${ }^{12}$ Conrad Weiser, Berks County, Oct. 15, 1747, in Sipe, Indian Chiefs of Pennsylvania, 101. Weiser also reported to Logan that Lappapitton feared that by accepting this position, he 
With the snub of Pisquetomen, an interregnum existed among the western Delawares. They would not yield to the demands of the Proprietors, but they also knew that until the crisis was resolved, western Delawares remained in a state of diplomatic limbo. Whatever voice or influence they had maintained with the Pennsylvania government was now silenced.

Patience wore thin within the alliance. Hamilton was eager to settle the matter and to give the Delawares one last chance. He hoped they would "agree about the Affair" of choosing a new leader; a headman palatable to all parties. ${ }^{13}$ At the Logstown Treaty talks (about sixteen miles to the north of Pittsburgh, along the Ohio River) on May 28, 1751, the Irish-born trader and Indian agent George Croghan, speaking on behalf of the Six Nations and Governor James Hamilton, prodded the Delawares to "choose amongst Yourselves one of your wisest Counsellors and present to your Brethren the Six Nations and me [Hamilton] for a Chief, and he so chosen by you shall be looked upon by us as your King. . . "14 Remembering the Pisquetomen debacle, the Delawares were hesitant to do so. Tamaqua was fully aware of the importance of a leader who would represent all Delawares, east and west, and address their concerns to the Six Nations and Pennsylvania. He reminded an interpreter named Andrew Montour that it "would take some time to consider on a Man that was fit to undertake to rule a Nation of People" such as the Delawares. He also wanted to appoint a leader without opposition from the Pennsylvania-Six Nations alliance. ${ }^{15}$ And yet Tamaqua was aware that this leader needed to recognize the autonomous status of Ohio Delawares.

The interregnum continued into the spring of 1752 . The second treaty talks held at Logstown altered the situation and ended the crisis. In late May of 1752, Virginia commissioners met with Delawares at Shannapin's Town on the east bank of the Allegheny River (two miles from current-day Pittsburgh). They noted that the Delawares had no king, but were represented by Shingas and his brother Tamaqua, both of whom, supplied with coats and hats by the commissioners, "were dressed after the English fashion." Both wore "silver Breast Plates and [had] a great deal of Wampum about them." They made favorable impressions with the

would be "bewitched" by supporters of Pisquetomen. See Weiser to Logan, Oct. 15, 1747, Logan Papers, 11: 33.

${ }^{13}$ Governor Hamilton to George Croghan and Andrew Montour, Feb. 7, 1750, in Pennsylvania Archives, 4th Series, 2: 146-147.

${ }^{14}$ Croghan to Delawares at Logstown, May 28, 1751, in MPCP 5: 533; Weslager, The Delaware Indians, 209.

15 Tamaqua to Montour at Logstown, May 29, 1751, in MPCP 5: 536-537. 
commissioners, who informed the Delawares that they were to meet the Six Nations at Logstown to further positive relationships between the King's representatives and the Ohio Indians. ${ }^{16}$

At the Logstown Treaty talks in June and July of 1752, the Ohio Land Company of Virginia and Virginia commissioners sought to gain confirmation of the 1744 Lancaster Treaty in which the Six Nations supposedly gave up territory to Virginia that bordered the Ohio River on the southeast. They wanted permission from the Ohio tribes to build a fort at the forks of the Allegheny and Monongahela rivers. They also sought to open a fair and adequate trade with the Ohio Indians and to exploit the potential of a half-million acres of unsettled land. ${ }^{17}$ The Six Nations refused to attend. Onondaga instead sent their half-kings (Ohio Senecas or Mingos) to supervise the affairs of the Ohio tribes and to protect Iroquois interests. ${ }^{18}$

At Logstown, the Virginia and Pennsylvania delegates turned their attentions to the Delawares and Shawnees and reminded them to "beware of French Councils" and to "adhere to a strict friendship" with the English colonies and the Six Nations. ${ }^{19}$ Tanacharison (also known as Half King), the Seneca supervisor of Ohio Indian affairs, sensed that the Virginia commissioners were recognizing the prominence and autonomy of the Ohio tribes. Grandstanding in front of the colonial officials and traders, he asserted the rights of the Iroquois to administer the affairs of the Ohio Indians. Tanacharison scolded both the Delawares and Shawnees for their war excursions into Cherokee country after they had made peace with them: "I take the Hatchet from you; you belong to me, \& I think you are to be ruled by me, \& I joining with your Brethren of Virginia,

16 Journal of the Virginia commissioners, May 29, 1752, in "The Treaty of Logg's Town, 1752," Virginia Magazine of History and Biography 13 (1905-1906): 155.

17 Ibid., 143 and comments of Lois Mulkearn in Lois Mulkearn, ed., George Mercer Papers relating to the Ohio Company of Virginia (Pittsburgh: University of Pittsburgh Press, 1954), xiii.

18 For an excellent definition of half kings among the Ohio Indians see Hunter, "The Ohio, The Indian's Land," 339-341. An Iroquois leader demanded that talks with New York governor George Clinton, regarding Ohio land, be held in Albany, recognized by the Iroquois as a traditional negotiating site. To diminish the increasing importance of the Ohio Indians, he added, "it is not our custom to meet to treat of affairs in the woods and weeds" of the Ohio. Iroquois leader quoted in Harry M. Ward, "Unite or Die": Intercolony Relations 1690-1763 (Port Washington, New York: Kennikat Press, 1971), 141.

19 Virginia commissioners to Delawares and Shawnees, June 1, 1752, in "Treaty of Logg's Town," 164. 
order you to go to war no more." 20 The Iroquois "took it very ill" that the Virginia officials treated with other Indian nations "without first consulting them."21

The Iroquois also made it their business to assign a leader to the Delawares and put an end to their obstinacy. Onondaga instructed Tanacharison to end the interregnum and decide on a leader acceptable to all parties. At Logstown, the half-king presented Shingas of the Turkey phratry as his choice. Tanacharison contended "that is our right to give you a King" to represent the Delawares in "all publick Business" between the Delawares, Six Nations, and the British. ${ }^{22}$ Under the illusions that western Delawares were receptive to the dictates of Onondaga, he announced to the Virginia commissioners, "we have given our Cousins, the Delawars, a King, who lives there, we desire you will look upon him as a Chief of that Nation." 23 Shingas was not present at that time. Tamaqua "stood proxy for his brother and was presented with a lace hat and jacket and suit."24

The rhetoric of the Logstown talks revealed much about waning Iroquois influence and a subtle reassertion of Delaware independence in the west. The Half King's scolding of Delaware war endeavors, much like the oratorical bullying of Canasatego a decade earlier at Lancaster, demonstrated that Tanacharison was posturing on behalf of the Six Nations in the presence of Virginia officials. The Delawares, who by definition of their status as tributaries were forbidden to go to war unless given permission, were moving away from Six Nations' control. They feared the wrath of Virginia more than they feared the Iroquois. The appointment of Shingas also disclosed much about the Delaware struggle to gain self-rule. While the Delawares opposed the "overlord intervention and manipulation" of the Six Nations in the selection of a leader, for the most part they favored Shingas. ${ }^{25} \mathrm{He}$ was their choice and he would prove to be "far from being

20 Tanacharison, June 4, 1752, in ibid., 165; Mulkearn, ed., George Mercer Papers, 61; Jennings, "Delaware Interregnum," 196-197.

${ }^{21}$ Richard Peters to Conrad Weiser, Feb. 6, 1753, mss., "Correspondence of Conrad Weiser," 1: 38.

22 Tanacharison, June 11, 1752, in "Treaty of Logg's Town," 164.

23 Ibid., 168.

24 Virginia commissioners, June 11, 1752, in "Treaty of Logg's Town," 167.

25 Jennings, "Delaware Interregnum," 194. C. A. Weslager contends that the majority of Delawares did not approve of the selection of Shingas to speak for all Delawares. New Jersey and other eastern Delawares had their principal leaders and many Ohio Indians did not approve of this appeasement to Onondaga demands. Weslager believes that Shingas and Tamaqua were figurehead leaders chosen by the Six Nations and opposed by most Ohio and Susquehanna 
a lickspittle client of the Iroquois or of the English."26 Ohio Delawares, by accepting Shingas as a favorable compromise, were on the verge of gaining political recognition as a distinct Ohio Indian nation. Though dismissed as "warriors \& hunters" by Tanacharison, the mutual acceptance of Shingas terminated a potentially dangerous situation and both the Six Nations and the Delawares saved face in the matter.

The Six Nations did not fare as well in other diplomatic areas. Tanacharison reminded the Virginia officials "that the lands then sold [by the Six Nations at Lancaster in 1744] were to extend no further to the sunsetting than the hill on the other [eastern] side of Allagany Hill."27 By the conclusion of the Logstown conference, the Ohio Company of Virginia pressured a reluctant Tanacharison to accept Iroquois land cessions to go beyond the Alleghenies. The Delawares and the Ohio Indians opposed any land cessions of Ohio country, but requested that Virginia build a "strong House" at the mouth of the Monongahela River--a small trading fort to provide protection and to supply them with needed trade goods. And yet the Ohio Indians did not agree to allow for Anglo settlement of the region. ${ }^{28}$ The Oneida half king to the Shawnees named Scarouady warned, "we [the Ohio Indians] intend to keep our country clear of settlements." 29

Regarding western Delawares and their push for autonomy from Six Nations' intervention, Conrad Weiser saw things a bit differently than Pennsylvania official Richard Peters had in 1750. According to Weiser, unlike Peters' contentions that the tributary tribes in Ohio were humoring the Iroquois, the Ohio Indians understood the close connection of the Iroquois to the British. To cover themselves, they acknowledged their relationship to the Iroquois, even on a symbolic level. When Delawares and Shawnees on the Ohio sent wampum

Delawares. He also notes that Shingas, who feared for his life when the Pennsylvania government placed a bounty on his head in 1756, relinquished his position to his brother, Tamaqua. See Weslager, The Delaware Indians, 236-237. Ironically, Pennsylvania and Virginia officials later regretted the selection of Shingas. He became the scourge of colonial frontiers and was known to American settlers as "Shingas the Terrible." See Weslager, The Delaware Indians, 209-211.

${ }^{26}$ Francis Jennings, Empire of Fortune: Crowns, Colonies \& Tribes in the Seven Years' War in America (New York: W. W. Norton \& Company, 1988), 41.

${ }^{27}$ Mulkearn, ed., George Mercer Papers, 56-57; “Treaty of Logg's Town,” 161, 168.

28 Mulkearn, ed., George Mercer Papers, 136-137; “Treaty of Logg's Town," 171, 173-

174; McConnell, A Country Between, 93-98; Jennings, Empire of Fortune, 38-44, 55-56.

${ }^{29}$ Scarouady in McConnell, A Country Between, 98. Also spelled Scarouyady. See Merrell, Into The American Woods, 33. 
belts to Onondaga in the spring of 1754 , asking to be relieved of their status as non-warrior tributaries, they were in essence also appealing to the British. Western Delawares exploited their image as tributaries to manipulate the council at Onondaga. ${ }^{30}$ They pleaded, "We expect to be killed by the French ... We desire, therefore that You will take off our Petticoat that we may fight for ourselves, our Wives and Children; in the Condition We are in You know we can do nothing." 31

The Logstown Treaty of 1752 demonstrated that the world of the western Delawares and Ohio Indians was about to undergo drastic change. For the Delaware leaders at Kittanning and the Kuskuskies, it was becoming increasingly difficult to maintain a symbolic vassalage to a Confederation that lacked the power to assert over lordship. Delawares demonstrated a sense of strength despite the compromise on the issue of a new political leader. They also managed to keep aligned with the British as a link in the Covenant Chain. Positive relations with the British were necessary for survival in their new homeland. Contending European empires were aligning themselves in preparation to fight for the valuable resources of the Ohio region. The Ohio Indians would eventually be dragged into the fray as the French increased in numbers in the west.

The French accelerated their presence in the Ohio in 1749 when the Governor of New France, Marquis de la Galisonniere, sent Captain Bienville de Celeron to enter the Ohio and warn off English traders, "interlopers and vagabonds." Celeron found a group of traders on the Ohio and ordered them to leave. They returned "with all their effects" to Philadelphia. ${ }^{32}$ Most of the Ohio tribes were greatly attached to and dependent upon British traders and were not impressed by Celeron's posturing on behalf of the French empire or his claiming of the Ohio

${ }^{30}$ For an analysis regarding the verbal shifts of the woman metaphor see Jane T. Merritt, At The Crossroads: Indians and Empires on a Mid-Atlantic Frontier, 1700-1763 (Chapel Hill: University of North Carolina Press, 2003), 222-223; Shoemaker, "An Alliance Between Men," 242-243. Shoemaker considers the Delaware manipulation of the woman metaphor to be "verbal maneuvers." Also see Appendix 2.

31 Weiser to Governor Hamilton, May 7, 1754, in MPCP 6: 36-37.

32 Captain Bienville de Celeron, from "Our Camp on the Beautiful River," to Governor Hamilton, Aug. 6, 1749, in E. B. O'Callaghan, ed., Documents Relative to the Colonial History of the State of New York 15 vols. (Albany: Weed, Parsons, and Co., 1856-1887), 6: 532-533. (Hereafter NYCD). 
territory in the name of the King of France (Celeron had lead plates placed at the mouth of rivers and tin plates nailed to trees claiming the Ohio as a French possession). ${ }^{33}$

In his expedition, Celeron was rebuffed by Delawares at Kittanning, an amalgamation of Ohio Indians at Logstown, and Shawnees on the Scioto River. Dejected, he admitted that such a small force of military made little impression on the Ohio Indians, who were "very badly disposed towards the French, and are entirely devoted to the English." 34

Because of Celeron's failed mission, the French altered frontier policy and embraced a more conciliatory, diplomatic approach towards the Ohio Indians. Rather than threatening noncompliant Indians, the new Canadian governor, Marquis de la Jonquiere, reformed French policy in the west. He restored alliances with the Great Lakes tribes of Ottawas, Wyandots, Potawatomis, Miamis, and others in hopes that they would influence the Ohio Indians. The French then recognized the sovereignty of Indian tribes, such as the Delawares, and their rights to tribal lands. Lastly, to counter British economic presence, the French assaulted British traders and slowly built a military presence as they constructed a series of forts. ${ }^{35}$

While the Ohio Delawares did not see the French as a threat, they saw the advance of the Ohio Land Company of Virginia into the region in 1750 as a direct challenge; an encroachment that was unacceptable to the tribes. Celeron had reminded the Delawares at Kittanning that what Pennsylvania had done to Delaware independence in the east would be repeated in the west unless Delawares allied themselves with the French. ${ }^{36}$

Tensions increased as the French gained a foothold in the west. In June of 1752 a Frenchorganized coalition of 240 Chippewas, Ottawas, and Potawatomis, led by a Metis named Charles Langlade from Michilimackinac, attacked and ravaged the Miami Indian town and English trading center of Pickawillany (near current-day Piqua, Ohio). Women and children suffered the

${ }^{33}$ McConnell, A Country Between, 85-90; Richard White, The Middle Ground: Indians Empires, and Republics in the Great Lakes Region, 1650-1815 (New York: Cambridge University Press, 1991), 204, 206-208; Jennings, Empire of Fortune, 16-17. Celeron did not impress Indians with his small force of 213 Canadians and thirty French Mohawks known as Caughnawagas.

${ }^{34}$ Celeron to Marquis de la Galisonniere in Montreal, Nov. 9, 1749, in Donald H. Kent, ed., The French Invasion of Western Pennsylvania, 1753 (Harrisburg: Pennsylvania Historical and Museum Commission, 1954), 9-10; Jennings, Empire of Fortune, 16-17.

35 White, The Middle Ground, 209-225; McConnell, A Country Between, 86-88.

${ }^{36}$ McConnell, A Country Between, 88. 
brunt of the casualties because most of the Miami warriors were on a hunting excursion. The war party also killed a few British. ${ }^{37}$

In response to the massacre at Pickawillany and the construction of French forts in the Ohio and Allegheny valleys, Virginia Governor Robert Dinwiddie dispatched a party under a young provincial major named George Washington to warn the French from the Ohio. 38 Washington, through Tanacharison as a mediator, also addressed a group of Delawares. Washington promised them that he was there to "put you again in possession of your lands [and] to dispossess the French" from the Ohio. ${ }^{39}$ The Delawares were skeptical of Washington's promises and were also offended that he did not address the Delawares directly, but instead used Tanacharison as a middleman. They told Washington that they had their own leaders who would be willing to hear his words. They also told him that they opted not to get involved in the conflict between the French and English. 40

However, Delawares were also receiving invitations in the form of wampum belts from the French to join the alliance of western Indian nations. Tanacharison acting on behalf of Washington and the Six Nations, met with Shingas at Kittanning on October 31, 1753.

Tanacharison ordered that the Delawares bring to him all the wampum belts sent by the French. Shingas claimed that the Wolf Delaware leader Custaloga (Pakanke) held the belts received by the Delawares at Venango and that he refused to relinquish them. ${ }^{41}$ While the Wolf contingent of Delawares was moving toward supporting the French, the Turtle-Turkey groups of Delawares remained out of the conflict as the French and their Indian allies assaulted and gained control of

${ }^{37}$ Hinderaker, Elusive Empires, 44; White, The Middle Ground, 230-231. It was during this attack that the principal Miami leader la Demoiselle, a supporter of the English, was killed, boiled, and eaten

38 J. Martin West, ed., War For Empire in Western Pennsylvania (Harrisburg: Pennsylvania Historical and Museum Commission, 1993), 19. The British Crown promised the Ohio Land Company of Virginia 500,000 acres in the Ohio if this region could be cleared for settlement.

${ }^{39}$ Entry of George Washington, June 17, 1754, in The Diaries of George Washington, 1748-1794, ed., John C. Fitzpatrick, 4 vols. (Boston: Houghton Mifflin Co., 1925), 1: 87-88.

40 Entries of Washington, June 18-19, 1754, in ibid., 1: 93-95.

${ }^{41}$ George Washington, The Journal of Major George Washington: An Account of His First Official Mission, Made as Emissary from the Governor of Virginia to the Commandant of the French Forces on the Ohio, October 1753-January 1754 (Williamsburg, Virginia: Facsimile Edition, Published by the Colonial Williamsburg Foundation, 1959), 12-13; Jennings, Empire of Fortune, 52-53, 60-61. Washington maintained that Shingas feared the strong military presence of the French at Venango and thus could not get Custaloga to give up the Delaware belts. 
Fort Necessity, Washington's outpost at the Great Meadows in western Pennsylvania.

Washington surrendered to the French on July 4, 1754.42

Despite their neutral status, there was tension between the Ohio Delawares and the Pennsylvania government. This animosity increased on July 9, 1754, during the Albany Conference between the Six Nations and representatives from various American colonies. Six Nations leaders granted to the Pennsylvania proprietors Delaware lands and Iroquois claims "on both sides [of] the River Susquehanna" as far east as the Delaware River and as far "Northward" as the Appalachian Mountains "as they cross the Country of Pennsylvania." 43 The Iroquois claimed that because of their covenant with the English, they had "Rights to the said Lands and Premises ... solely in them and their Nations, and in no other Nation whatsoever. ..." The Six Nations delegation promised that the agreement would last and "mutually be preserved between both the said Parties and their Children and Children's Children" forever. ${ }^{44}$

A month after Albany, over two hundred Ohio Indians met at George Croghan's home at Aughwick, in present-day Huntingdon County, Pennsylvania. The half kings Tanacharison and Scarouady complained to Conrad Weiser, who was in the capacity of a representative of Pennsylvania governor Robert Hunter Morris, that the Onondaga council had relinquished too much western land to Pennsylvania. 45 The Delawares voiced their concerns through Tamaqua, who addressed both Weiser and the Six Nations. With shrewd oratorical maneuvering and a respect for traditional protocol, he reminded them of their histories and obligations and that the Delawares had lived under Iroquois protection during times of peace. He advised the Iroquois that the tributary Delawares looked to the Confederacy for protection. He also noted that it was the Six Nations who had forbidden them to "mettle with Warrs, but [as the men, forced the women to] stay in the House and mind Counsel affairs." Tamaqua pleaded that because of a "high Wind" rising, (the French presence in the Ohio), "we desire you therefore Uncle to have

42 Jennings, Empire of Fortune, 66-67; Weslager, The Delaware Indians, 214; West, ed., War For Empire, 22-23

43 "Deed from the Six Nations to the Proprietors," Albany, July 9, 1754, in MPCP 6: 125.

44 "Deed from the Six Nations to the Proprietors," July 6, 1754, in ibid., 6: 121.

45 Wallace, Weiser, 368-369; Sipe, Indian Wars of Pennsylvania, 309-311. Tanacharison also complained to Weiser regarding George Washington's inexperience, ineptness, and inability to take the advice of Indians. All he believed contributed to the disaster at Fort Necessity in early July of 1754. See Beauchamp, ed., Life of Conrad Weiser, 101-102. 
your Eyes open, and be Watchful over us your Cousins, as you have always been heretofore."46 Diplomatically and with deference to the Delaware status within the structure of the Covenant Chain, he insisted that if the Iroquois could not protect the Delawares from the French, then they should permit the Delawares to pick up a hatchet and defend themselves. As the majority of western tribes came to support the French, Tamaqua worked hard not to sever Delawares from the British orbit.

Tamaqua then turned to Weiser and reminded him of Pennsylvania's fair treatment of his people from the time "William Penn first appeared in his Ship on our Lands" and was accepted by the Delawares and Five Nations into a union of "lasting Friendship." He asked Weiser to tell the governor of Pennsylvania that "we desire that you will look upon us in the same Light, and let that Treaty of Friendship made by our Forefathers on both sides subsist. . .."47 Tamaqua knew that western Delawares would not tolerate the territorial encroachments of Pennsylvania into the Ohio. He hoped to avert conflict by appealing to Pennsylvania to remember its traditions and history of fair treatment towards the Delawares. To avoid war with Pennsylvania, he was willing to acknowledge a degree of over lordship of the Six Nations in hope that they would intervene with Pennsylvania on behalf of the Delawares.

Weiser was not as optimistic regarding a soothing of strained relations between the Iroquois and Ohio Indians. He rejected the half-kings' objections regarding the Albany Treaty and remarked that the "Ohio Indians had no business at the Treaty, and the Six Nations always declared them Hunters, and no owners of Land. . .." He emphasized that the Ohio was strictly a hunting domain of the Indians, not a homeland. In fact, Weiser admonished the Delawares and Shawnees who "ignored the advice of the Six Nations" and moved to the Ohio and refused to return to the east despite the "repeated Request of the Six Nations." 48

46 Tamaqua (Beaver) to Six Nations delegation at George Croghan's trading post (Aughwick), September 4, 1754, in MPCP 6: 155-156. Ohio Delawares had made similar pleas for the Six Nations to "take off our Petticoat" at an earlier date. On May 7, 1754, a Delaware delegation from Ohio country met with Weiser and the Iroquois at Shamokin. Respective of their symbolic designation as women, they urged the Six Nations to let them take up the hatchet against the French and "die in Battle like Men." See MPCP 6: 36-37

47 Tamaqua to the Six Nations, Sept. 4, 1754, in Wallace, Weiser, 369.

48 Weiser, July 1754, in ibid., 360; Weiser in Beauchamp, ed., Life of Conrad Weiser, 83, 103-104. 
The Albany land exchange, lamented politician and schoolmaster for the Quakers Charles Thomson, aggravated a dangerous situation, for it forever altered the relationship between Pennsylvania and its Indians. The Delawares were "violently driven from their Lands" and "reduced to leave their Country." No doubt because of this loss of land, many Delawares eventually gave "Ear to the French, who declared that they did not come to deprive the Indians of their Land . . but to hinder the English from settling westward" of the Allegheny Mountains. ${ }^{49}$ At Albany, the Delawares were essentially thrown "entirely into the Hands of the French."50

Thomson may have overestimated Delaware attention to French overtures. Western Delawares were cautious not to burn bridges behind them. Despite Washington's demoralizing defeat and surrender at Fort Necessity in July of 1754, events that weakened English influence in the Ohio, many western Delawares still respected British power and sought to remain in the British sphere. ${ }^{51}$ On the eve of Major General Edward Braddock's march to the three rivers of the Allegheny, Monongahela, and Ohio, Weiser urged the proprietor Thomas Penn to persuade the Iroquois to release the Delawares from their tributary obligations, remove their status as cousins, and "give them a Breech Cloath to wear." 52 Shingas and a small party of Ohio warriors met with Braddock and his command along the road as he marched to assault the French stronghold at Fort Duquesne in the late spring of 1755. Shingas claimed that the Delawares of the Ohio desired to "Live and Trade Among the English and Have Hunting Ground sufficient to support themselves and [their] Familys." They offered their services to Braddock if the English general could assure the Delawares that their land would not be disturbed. Braddock coldly

49 Thomson, An Inquiry into the Causes, 78. Also see MPCP 6: 84. Conrad Weiser commented on what can be seen as an irony. At Albany on July 4, colonial delegates (with exception of Virginia and New Jersey) also met and the "plan for a Union of the Colonies was debated, [and agreed upon by the Albany Congress] but nothing was finally determined on." The plan of union was rejected by the individual colonies. See MPCP 6: 87. A New York commissioner commented that the "Colonies being in a divided disunited State" made no attempt to challenge the encroachments of the French. The English colonies, at that time, were believed to be "unable and unwilling to maintain the Cause of the whole." See the comments made at the Albany Congress on July 9, 1754, in MPCP 6: 103.

50 Thomson, An Inquiry into the Causes, 77.

51 Wallace, Teedyuscung, 67.

52 Weiser to Thomas Penn, May 1755, in Wallace, Weiser, 271. Weiser believed that the term cousin in Indian metaphor meant "a Subject or one that is under Command." 
refused their help and asserted that only the "English Should Inhabit \& Inherit the Land." $53 \mathrm{He}$ refused to acknowledge the territorial rights and sovereignty of a people he referred to as "Savages."54 These rejected Indians--a "smattering of Delawares," Mingos, and Shawnees, joined the western tribes of Wyandots, Ottawas, Chippewas and Pottawatomies to ally with the French. A combined force of 850 Indians and French waited for Braddock eight miles outside of Fort Duquesne (current day Turtle Creek). There they met and destroyed Braddock's British regulars and colonial militia of 1,300 men. ${ }^{55}$

Despite Braddock's defeat, described by Indians as that "what passed on Monongahela," the continuous overtures of the French, and the lack of a British military presence in the Ohio, western Delawares were willing to remain loyal to the Crown. Scarouady, the Iroquois viceregent, made an appeal before the Pennsylvania governor, council, and assembly to support the majority of western Delawares, who he believed were not willing to join the French. He hoped that Pennsylvania would sanction the Delawares as warriors and remove the petticoat, by providing them with guns and powder. Scarouady told Pennsylvania governor Robert Hunter Morris, that the Ohio groups of Delawares were prepared to unite and "one word of yours will

53 This is the testimony of Shingas of what happened at this meeting in Braddock's tent. See NYCD: 7: 270. George Croghan contended that Braddock agreed to Shingas's proposal, but the Delawares reneged on the deal. The version of Shingas has been accepted for the historical record. For an alternative view see "Croghan's Transactions with the Indians Previous to Hostilities on the Ohio," in Reuben G. Thwaites, ed., Early Western Travels, 1748-1846, 32 vols. (Cleveland: Arthur H. Clark Company, 1904-1907), 1: 97-98.

54 General Braddock in NYCD: 7: 270. See Paul E. Kopperman, Braddock on the Monongahela (Pittsburgh: University of Pittsburgh Press, 1977), 100-102 for details on those Delawares who offered to aid Braddock and his army but were turned away. In regard to Braddock's Indian allies, there is much discrepancy. C. Hale Sipe in Indian Wars of Pennsylvania maintains that Braddock refused the assistance of the Delawares and Shawnees and was promised Cherokees and Creeks by Governor Robert Dinwiddie of Virginia--they failed to arrive.

55 Charles Hamilton, ed., Braddock's Defeat: The Journal of Captain Robert Chomley's Batman-The Journal of a British Officer-Halkett's Orderly Book (Norman: University of Oklahoma Press, 1959); Thomas A. Lewis, For King and Country: The Maturing of George Washington, 1748-1760 (New York: Harper Collins Publishers, 1993), 176-177; Robert L.D. Davidson, War Comes to Quaker Pennsylvania, 1682-1756 (New York: Columbia University Press, 1957), 147; Walter O’Meara, Guns At The Forks (Englewood Cliffs, New Jersey: Prentice-Hall Inc., 1965),110-112, 117-139; Sipe, Indian Wars of Pennsylvania, 177-202. These are but a few narratives of this much written about account of Braddock's Defeat. Braddock was mortally wounded in this battle, his army sustained losses of 977 killed or wounded. 
bring the Delawares to join you."56 The word did not come. The French, on the other hand, offered Delawares military support and needed trade goods, such as powder and muskets, to stave off starvation. In consideration of the British failure to militarily assert themselves in the Ohio and the silence from Philadelphia, many Delawares became impatient and joined the French.

With Scarouady 's pleas ignored, Ohio Delawares became fully alienated from the Pennsylvania government. As Pennsylvania settlement included the far regions of the western Susquehanna to the Juniata Rivers, more Delaware bands trickled over the Alleghenies into the Ohio country towns to show their solidarity and independence as Delawares. Throughout the eighteenth century, Delawares "had to submit to such gross insults" such as their emasculation at the hands of the Pennsylvania-Iroquois alliance. However, as John Heckewelder observed, "they were not ignorant of the manner in which they might take revenge" on their transgressors. ${ }^{57}$ Because of this treatment at the hands of the Six Nations and Pennsylvania, [Delawares] "took a severe Revenge on the Province, by laying Waste their Frontiers" and paid little attention to Iroquois commands from Onondaga. ${ }^{58}$

The peace that had existed between the Delawares and Pennsylvanians since 1682 when William Penn negotiated a treaty at Shackamaxon, ended on October 16, 1755. Delaware war parties from the Turtle-Turkey stronghold at Kittanning led by Shingas, Pisquetomen, and the war captain known as Captain Jacobs moved east into the Susquehanna River region and entered the settlement of Penn's Creek in current-day Snyder County. Delaware warriors rushed into the home of Barbara Leininger and announced, "we are Alleghany Indians, and your enemies. You must die." They shot her father, clubbed her brother to death, and took Barbara and her sister captive. Within three days, the Delawares destroyed most of Penn's Creek, taking prisoners, burning farmhouses, and stealing horses. 59

56 Report by Scarouady to Governor Robert Hunter Morris in Philadelphia, August 22, 1755, in MPCP 6: 589-590. Also see Boyd, ed., Indian Treaties by Benjamin Franklin, 1xix. Boyd contends that this report by Scarouady was his declaration of independence on behalf of all Iroquois tributaries. The comments regarding the place of Braddock's defeat can be attributed to a Shawnee chief named Paxonosa to Weiser in the fall of 1755. See MPCP 7: 49.

${ }^{57}$ Heckewelder, An Account of the Indian Nations, xxxiii-xxxiv.

58 Thomson, An Inquiry into the Causes, 47.

${ }^{59}$ Barbara Leininger in Randolph C. Downes, Council Fires on the Upper Ohio: A Narrative of Indian Affairs in the Upper Ohio Valley until 1795 (1940; Reprint, Pittsburgh: 
Delaware war parties then fell upon the "Inhabitants on Mahanahy Creek," a tributary of the Susquehanna River, took captives and torched the community. One month later Delawares and Shawnees "crossed the Sasquehanna and fell upon the County of Berks." 60 Settlers were "greatly alarmed and terrified" that the Delawares, with a handful of Shawnee allies, and (possibly) a few French Mohawks could inflict so much suffering and damage, particularly since the proprietors had purchased much of this land from the Six Nations. ${ }^{61}$

Delawares at Kittanning, "encouraged by the Retreat of the [British] Forces," gravitated to the French, whom they saw as more powerful and a safer bet as an ally than the English. ${ }^{62}$ The constant rumors of a large force of French and allied western Indian nations sweeping through the Ohio did much to push Delawares into action. ${ }^{63}$ Shingas and Pisquetomen made a preemptive strike and hoped by doing so, to discourage future Anglo-American settlement beyond the Alleghenies. They also believed that the French could assure them security of their homeland--a factor vital in the nurturing of Delaware unity and independence. Bands of eastern Delawares also perceived British military ineptness in the west and joined their western kin in the 1755 attacks on the Pennsylvania frontier.

As a result of these ferocious Indian raids, the frontiers of Pennsylvania, Maryland, and Virginia were cleared of Anglo settlers. By the spring of 1756, over 700 settlers had been killed or taken captive, pacifist Quaker assemblymen were purged from Pennsylvania government for not funding frontier defense; by 1758 Virginia was forced to construct twenty-seven forts from

University of Pittsburgh Press, 1969), 75-76; Marie LeRoy and Barbara Leininger, "The Narrative of Marie LeRoy and Barbara Leininger, For Three Years Captives Among the Indians," Edmund de Schweinitz, ed., The Pennsylvania Magazine of History and Biography 29 (1905): 407-420.

${ }^{60}$ A brief narrative of the events of October-November 1755, presented to Governor Morris in Philadelphia, December 29, 1755, in MPCP 6: 766-767.

61 Assembly of Pennsylvania to Governor Morris, Nov. 5, 1755, in ibid., 6: 677.

62 Governor Morris to the Pennsylvania Assembly in Philadelphia, July 28, 1755, in Pennsylvania Archives, 4th Series, 2: 438-439.

63 Scarouady warned Pennsylvania officials that over a thousand French, Ottawas, Miamis, and Shawnees were preparing to move east on the war trail, as far as Carlisle. All Delawares who remained loyal to the British would be killed. See Scarouady to council in Philadelphia, Nov. 8, 1755, in MPCP 6: 683. It was also rumored that these Indians "were to be followed by a large number of French and Indians from Fort Du Quesne, with a design of dividing themselves into parties to fall upon" the rest of Pennsylvania and the frontiers of Virginia. See Assembly of Pennsylvania to Governor Morris, Nov. 5, 1755, in ibid., 6: 677. 
the Blue Ridge to the Allegheny Mountains. ${ }^{64}$ These raids forced Pennsylvania to rethink its Indian policy regarding the western Delawares and Shawnees.

The violent outbreaks on the Pennsylvania frontier demonstrated both the Delawares' anger against the provincial government of Pennsylvania and a disappointment on the failure of the British to offer them territorial security. Two Ohio Delawares, serving as messengers for the victorious warriors of Kittanning, visited the Susquehanna River town of Scarouady and proclaimed: "We, the Delawares of Ohio, do proclaim War against the English. We have been their Friends many years, but now have taken up the Hatchet against them, \& we will never make it up with them whilst there is an English man alive." 65 They danced a war dance and then stated "When Washington [at Fort Necessity] was defeated We, the Delawares were blamed as the Cause of it. We will now kill. We will not be blamed without a Cause."66

Three factors enabled the bands of Shingas and Pisquetomen to assert their independence in the west and to enjoy a resurrected military reputation. First, because of the lack of a strong British military presence in the Ohio, they could retaliate at will against Pennsylvania. Second, the French were more than willing to support these potentially powerful allies. Finally, the Six Nations did not have the presence of authority in the Ohio, other than a symbolic relationship with the western Delawares.

Major General William Shirley, commander-in-chief of his majesty's forces in North America during the war's early years, was shocked at the behavior of the Ohio Indians, tribes who "for a long time past lived in Friendship with the People" of Pennsylvania and bordering colonies. ${ }^{67}$ Shirley tried desperately to rejuvenate the former subservient role of Delawares to Iroquois dominance. He complained to Six Nations leaders that the Delawares had "always lived under your Direction. They looked upon you as their masters, and you looked upon them as Women who wore Petticoats. They never dared to do anything of Importance without your leave." He then cautioned the Iroquois that they needed to punish those Delawares who raided on

${ }^{64}$ Ian K. Steele, Warpaths: Invasions of North America (New York: Oxford University Press, 1994), 198; Downes, Council Fires on Ohio, 79-80. On the purging of the Quakers from the Pennsylvania assembly see Theodore Thayer, "The Quaker Party of Pennsylvania, 17551765," The Pennsylvania Magazine of History and Biography 71 (1947): 19-43.

${ }^{65}$ Report by Scarouady to Governor Robert Hunter Morris in Philadelphia Nov. 8, 1755, in MPCP 6: 683.

${ }^{66}$ Scarouady to Governor Morris, Nov. 8, 1755, in ibid., 6: 683.

${ }^{67}$ Shirley to Council of War, Dec. 12, 1755, in ibid., 7: 21-22. 
the Pennsylvania frontiers. If the Iroquois refused to assert their dominant status within the Covenant Chain, Shirley warned, the Delawares would "think themselves as good Men as you, and you will lose the name of being their Masters."68

Many western Delawares, however, reveled in their military successes and were adamant in their "Hostilities against the English." They would not cease even if "ordered to by the greatest Sachem in the Country of the [Iroquois] Confederates." 69 The Reverend Gideon Hawley told Governor Morris that despite the pleas of the influential Scarouady, the Ohio Delawares "were obstinately bent on the Destruction of the English." They would "pay no Regard to the Interposition of the Six Nations."70

The Iroquois sought to find the causes for Delaware discontent. In February 1756, the Onondaga speaker known as Red Head (Kaghswughtioni), visited Fort Johnson and conferred with Sir William Johnson about Delaware actions on the Pennsylvania frontier. He believed that they were "deluded by the craft" of the French and he promised to intervene and use "all means" at his disposal to pacify the hostility of the Delawares. ${ }^{71}$

The Iroquois were willing to concede that Delaware militancy against Pennsylvania was a result of the diplomatic failings of the Penn government. Red Head addressed Sir William Johnson and reminded him that the Six Nations "looked upon the Delawares as [in need of] the more immediate care of Onas." He believed that the "barbarous Behavior" in 1755 occurred because of Pennsylvania's lack of diplomacy. "Therefore our common Enemy [the French] hath taken the advantage of their neglect." Red Head reminded Johnson that proper attention paid to the Delawares would keep them strong in the Covenant Chain. ${ }^{72}$

Sir William Johnson agreed with Red Head that French seduction of the Ohio tribes was a contributing factor in the escalating violence against English settlers. He also believed that these Indians were disturbed by the continuous settlements that started to press into Indian hunting grounds. The Ohio Delawares spread their discontent "among their brethren who dwelt on the Susquehanna." The French then "propagated those prejudices against the good intentions

68 Shirley to the Six Nations, Dec. 12, 1755, in ibid., 7: 22.

${ }^{69}$ Reverend Gideon Hawley to Governor Morris, January 4, 1756, in ibid., 7: 12. Hawley visited a Delaware community in the Ohio and "just escaped with his life."

70 Reverend Hawley to Governor Morris, January 4, 1756, in ibid., 7: 14.

${ }^{71}$ Red Head to Sir William Johnson at Johnson Hall, Feb. 19, 1756, in NYCD 7:55.

72 Red Head of the Six Nations to Sir William Johnson at Fort Johnson, Feb. 19, 1756, in ibid., 7: 56, 61 . 
of the English." The French fed those Indians with promises and won over their support by "magnifying their prowess, kindness, and generosity." 73 Both Red Head and Johnson failed to acknowledge the attempted emasculation inflicted by the Six Nations upon Pennsylvania's tribes as a significant reason.

Despite the weak mediation of the Six Nations with regards to the rift between the Delawares and Pennsylvania, the uprising continued. In April of 1756, Governor Morris complained to Sir William Johnson, who was the Indian agent for the Six Nations and the soon to be Superintendent of Northern Indian Affairs for the British, that Delawares living at Kittanning and farther to the west on the Ohio River were "most mischievous" and continued to "murder and destroy our Inhabitants, treating them with the most barbarous Inhumanity that can be conceived." " I4 In what could be conceived as an attempt to bring together eastern and western Delawares, war parties converged on the frontiers of central Pennsylvania from two directions. Over 700 Delaware warriors came from the Ohio, while a few hundred approached white settlements from their villages on the Susquehanna. ${ }^{75}$ Before the Six Nations could fully hear Delaware complaints, Governor Morris declared war against the Delawares on April 14, 1756 and placed scalp bounties on all Delawares, who had waged war or aided the warriors. Morris's actions ended any chance of peace on the Pennsylvania frontier. ${ }^{76}$

Morris urged Pennsylvania citizens to "embrace all Opportunities of Pursuing, taking, killing and destroying the said Delaware Indians." He offered a premium bounty of "150 Spanish Dollars or Pieces of Eight" for any male Delaware over twelve taken captive, and "130 Pieces of Eight" for their scalp. The scalp of a Delaware woman was valued at "Fifty Pieces of Eight.""77 He also offered 700 pieces of eight for the scalps of Shingas and Captain Jacobs, the prominent

${ }^{73}$ Sir William Johnson to the Lords of Trade from Fort Johnson, May 28, 1756, in ibid., 7: 87.

${ }^{74}$ Morris to Johnson April 24, 1756, in MPCP 7: 98-99.

75 Weslager, The Delaware Indians, 231.

${ }^{76}$ Michael N. McConnell, "The Search For Security: Indian-English Relations in the Trans-Appalachian Region” (Ph.D. diss., The College of William and Mary, 1983), 149.

77 William Smith, A Brief State of the Province of Pennsylvania (London: R. Griffiths, 1756), 13-15. Governor Morris invited peaceful Delawares to settle closer to the Pennsylvania settlements in the east for their own protection against less discriminating bounty hunters. Also see Proclamation of Gov. Morris, April 1756, in MPCP 7: 88-89. 
Delaware war leaders. ${ }^{78}$ Morris condemned the actions of the Ohio Delawares who were looked upon by the Proprietors as "our own Children" and who in a "most cruel manner fallen upon \& murdered our Inhabitants, People whose Houses were always open to them. . ." He added that certain Delawares, unprovoked, had greatly damaged the "Chain of Friendship" that had historically bound them with Pennsylvania and the Six Nations. ${ }^{79}$

Morris's declaration of war in April of 1756 against the Delawares who raided on the frontier naturally incited more western Delawares to shift to the French orbit. The Iroquois asked the British to withdraw their military from the Ohio so that their half-kings could secure English captives and chastise those guilty of "base and treacherous Behaviour." 80 This was an arduous task. Many of the Turtle-Turkey Delawares at Kittanning, together with a few Susquehanna Delawares, were already on a full-fledged war footing against Pennsylvania and had no intention of apologizing for their actions or freeing captives. In the early spring of 1756, Shingas and Captain Jacobs led a war party out of Kittanning. The party burned a private fort named Fort McCord, killed twelve, and took many captives. ${ }^{81}$ In July, a combined party of French and Delawares led by Captain Jacobs moved against Fort Granville in Mifflin County, Pennsylvania, where they burned the fort and took more captives. ${ }^{82}$

Indian successes throughout the fall of 1755 and early 1756 shattered the Quaker policy of Indian pacification and increased the aggressiveness of the Ohio Indians. The ashes of Forts McCord and Granville "convinced the Pennsylvania back inhabitants that they needed to set aside their defensive passivity" and take the fight to the western Delawares. ${ }^{83}$ On September 8, 1756, Lieutenant Colonel John Armstrong and a force of 300 Pennsylvania militiamen moved into Indian country and attacked and burned Kittanning. Armstrong's mostly Scots-Irish force

78 Henry J. Young, “A Note On Scalp Bounties In Pennsylvania,” The Pennsylvania History, Quarterly Journal of the Pennsylvania Historical Association 24 (Jan.-Oct. 1956): 207.

79 Governor Morris to Scarouady and Andrew Montour, Philadelphia, November 14, 1755, in MPCP 6: 698-699; Governor Morris to Sir William Johnson, Philadelphia, Nov. 15, 1755, in Pennsylvania Archives, 4th Series, 2: 528-529.

80 NYCD 7: 57.

81 Sipe, Indian Wars of Pennsylvania, 273-274.

82 Ibid., 294-296.

83 James P. Myers, Jr., "Pennsylvania's Awakening: The Kittanning Raid of 1756," Pennsylvania History: A Journal of Mid-Atlantic Studies, 66 (SUMMER 1999): 403. 
freed ten captives and burned crops and a cache of weapons. ${ }^{84}$ The Reverend Thomas Barton noted that Captain Jacobs "fought, \& died, like a soldier. He refus'd to surrender when the House was even on Fire over his Head." 85 An English deserter who resided with the French at Fort Duquesne noted "That after the taking of Kittanning the Indians came to Fort Duquesne and told that they had buried upwards of 50 of their people that were killed there," including Captain Jacobs' wife and son. Shingas and his warriors fled north to Saukunk in the Beaver Valley. ${ }^{86}$

After Armstrong and his command left the smoldering Kittanning, the Delawares eventually returned with many of their English captives. ${ }^{87}$ While frontier raids continued, the boldness and aggressiveness of the Ohio Indians gradually diminished. They now dreaded the prospect of going on the war trail and leaving their towns open to the attack of militias.

Kittanning, while not abandoned, would no longer be used as a center of military operations during the French and Indian War. 88

Throughout 1756, the alienation of western Delawares from the Covenant Chain was complete. Many were now "under the protection of the French" and would no longer honor their previous treaties with Pennsylvania or the British. Governor Morris lamented that Delawares also refused to "submit to the Six Nations, to whom they owe obedience." 89 The spirit of autonomy also spread back across the Allegheny Mountains. Delaware chiefs, living near the Iroquois in the Wyoming Valley, announced in the fall that "five hundred of their people would move away from the English and settle ten leagues to the west," near the Ohio River. ${ }^{90}$ Western

84 Ibid., 399. There were over one hundred and forty Delaware and Shawnee warriors at Kittanning. There were also over one hundred and fifty white captives, mostly from Pennsylvania and Virginia. See the comments of Joseph Fox, Jan. 13, 1756, in MPCP 6: 781782.

85 Reverend Thomas Barton to Reverend William Smith, Sept. 23, 1756, quoted in Myers, "Pennsylvania's Awakening," 408.

${ }^{86}$ An English deserter Oct. 28, 1756, quoted in William A. Hunter, "Victory at Kittanning," Pennsylvania History, Quarterly Journal of the Pennsylvania Historical Association 23 no. 3 (July 1956): 29. Delawares also fled to Logstown on the Ohio and north to the Kuskuskies and Shenango. On these refugees see Sipe, Indian Wars of Pennsylvania, 311.

87 Hunter, "Victory at Kittanning," 28.

88 Myers, "Pennsylvania's Awakening," 399; Hunter, "Victory at Kittanning," 32-33; MPCP 6: 781.

${ }^{89}$ Governor Morris, April 15, 1756, in MPCP 7: 92; Governor Morris to Sir William Johnson, Philadelphia, Nov. 15, 1755, in Pennsylvania Archives, 4th Series, 2: 528-529.

90 The Marquis De Vaudrevil to the Minister in Montreal, August 8, 1756, in Stevens, ed., Wilderness Chronicles, 95. 
Delawares, confident in their ability to throw the frontier into chaos, challenged the Iroquois to take the hatchet against the English. In council with the Shawnees and Iroquois, the Delawares "reproached the Iroquois bitterly for their failure" to declare war against the British for their incursions into the Ohio. They told the Iroquois that they would no longer wear the petticoat. The Delawares insisted that the Iroquois now wore the petticoat and became the woman. The Ohio Delawares "wished to strike the English" and would call the "Abnakis their brothers, and that perhaps they would become crazy ... [and] even raise the hatchet against their uncles, the Iroquois."91 The Iroquois maintained that Delaware warriors who had attacked Pennsylvania frontiers bragged "We are Men," and warned that they would continue to fight as true warriors. These Lenapes, aware of their resurrected political and military prominence, cautioned the Iroquois to beware and not to interfere, "lest we cut off your private Parts and make Women of you, as you have done of us." They would "no longer . . . submit to the Six Nations." 92

The Delaware raids of 1755 demonstrated the "vehement masculinity of men rearmed." Delawares led by Shingas and Pisquetomen "cast aside the metaphorical petticoats and cornpounders" and set the American frontier on fire. ${ }^{93}$ Delawares were not weak and passive but a potentially powerful people who were caught in the pincers of the Pennsylvania-Six Nations alliance that threatened Delaware identity. The events during the fall of 1755 "had been in the making, gradually acquiring force and implacability, for decades." 94 Spearheaded by Delaware aggression out of Kittanning, the Ohio Indians emerged as a formidable power bloc in the west.

${ }^{91}$ Louis Antoine de Bougainville to Marquis de Rigaud, Lt. Governor of New France in Montreal, Jan. 30, 1757, in Edward P. Hamilton, ed., Adventures in the Wilderness: The American Journals of Louis Antoine De Bougainville, 1756-1760 (Norman: University of Oklahoma Press, 1964), 104-105. De Bougainville at that time was an aide-de-camp to the French General Louis-Joseph de Montcalm.

92 Speech of the Mohawk sachem named Little Abraham to Lieutenant Governor of Pennsylvania, William Denny at Lancaster, May 13, 1757, in MPCP 7: 522; the observations of Gov. Morris, April 15, 1756, in MPCP 7: 92. For an analysis on body parts and metaphor see Merrell, Into The American Woods, 213-214.

${ }^{93}$ Frank G. Speck, "The Delaware Indians as Women: Were the Original Pennsylvanians Politically Emasculated?," The Pennsylvania Magazine of History and Biography 70 (Oct. 1946): 388-389.

94 Jennings, "Delaware Interregnum," 174. 
Eventually the British, in their imperial struggle with the French, pressured the Six Nations to remove the petticoat from the Delawares and to secure them as military allies. ${ }^{95}$

George Croghan, newly appointed Deputy Indian Agent, confided to the Superintendent Sir William Johnson that it was the "Conduct of the [Pennsylvania] Assembly" that drove the Delawares "out of the British interest." 96 This conduct had been inherited from James Logan and his disastrous Indian policy. The "colonial officials would not have to look far" for the reasons for brutal Indian attacks on the frontier after Logan "forcefully and rudely" cast the Delawares aside. ${ }^{97}$ By pushing the Delawares and Shawnees from their traditional homes, Logan "opened the gate to colonial settlement" in the Susquehanna. His misguided policy eventually "guaranteed the deaths of hundreds of Pennsylvania's back settlers at the hands" of Delaware warriors seeking revenge for their mistreatment. ${ }^{98}$ The alliance between Pennsylvania and the Six Nations, sealed in 1732, came at a price--the "alienation of the Delawares, the full payment of which fell on the inhabitants" decades later. In choosing the Iroquois at the expense of Delaware autonomy, Pennsylvania dealt the Delawares a "taunting insult."99

As Pennsylvania bonded with the Six Nations, the Turtle, Turkey, and Wolf Delaware tribes of the west became physically and politically alienated. To gain security in their Ohio Valley homeland, Delawares defended their rights to choose their own leader and also displayed their defiance through military aggression. The Delaware attacks on white settlers that followed on the Pennsylvania frontier were a consequence of the "breakdown of the political institutions binding them in peace to the colony." 100

Delawares moved west and remembered the lessons of their past. While a minority of eastern Delawares remained locked into and subdued by a tenuous Iroquois/Pennsylvania relationship, the western Delaware tribes, led by the royal line of Shingas, Pisquetomen, and

${ }^{95}$ Speck, "The Delaware Indians as Women," 388-389. Also see Jennings, Empire of Fortune, 166-168, 190-191.

${ }^{96}$ Croghan to Johnson, December 1756, in Boyd, ed., Indian Treaties by Benjamin Franklin, lxxxii.

${ }^{97}$ De Varo, "Pennsylvania's Indian Policy," 83.

98 Jennings, Ambiguous Iroquois Empire, 345.

${ }^{99}$ Boyd's comments in Boyd, ed., Indian Treaties by Benjamin Franklin, xxxiii.

100 Jennings, "Delaware Indians in Covenant Chain," in Kraft, ed., Delaware Indian Symposium, 89 . 
Tamaqua broke free and enjoyed a new status as prominent warriors and diplomats of great consequence in the Anglo-Indian world. They did so without adhering to the attempted overlord dominance of the council fire at Onondaga. Though Tamaqua favored more mediation and diplomacy with the British, Pennsylvania, and Six Nations axis, he still looked to establish and protect the Delaware people in their new home. Seeing that the Covenant Chain alliance "had been organized for their destruction;" Delawares believed that their "very existence was at stake." 101 Western Delawares slowly embraced autonomy, commonality, and unity-- contingents of a process known as national growth. They abandoned their role as pacifists "into which they had been insidiously drawn."102 From the moment they picked up the hatchet and went to war against Pennsylvania, the "Delawares were turned, and became another People. ..."103 At the onset of the Seven Years' War, the Ohio Delawares "forced [the Covenant Chain of the Six Nations and Pennsylvania] to acknowledge they were Men ... a free independent Nation." 104

${ }^{101}$ Heckewelder, An Account of the Indian Nations, xxxiv.

102 Ibid., xxxiv.

103 Words of the Shawnee chief named Paxonosa, as interpreted by Conrad Weiser and conveyed to a council at Philadelphia, February 24, 1756, in MPCP 7: 49.

104 Thomson, An Inquiry into the Causes, 47. 


\section{Chapter III}

\section{"on behalf of all our Nation": \\ The Turtle, Turkey, and Wolf tribes \\ During the Seven Years' War and the Age of Pontiac}

Charles Thomson's observations of the frontier raids in 1755 as the definitive moment in the shaping of a Delaware nation were a bit premature, but nevertheless on the right track. The frontier uprisings were the ramification of the demographic pressures caused by Anglo settlement and the political inequities placed upon Delaware Indians by the Covenant Chain.

The Delaware nation, however, emerged in the west, not solely upon the need to vent frustrations and to avenge insults through bloody reprisals. A crucial factor in the rise of a Delaware nation was the geographical and political separation of the western and eastern Delawares. Despite the participation of bands of Susquehanna warriors in the raids of 1755, the political, as well as geographic chasm between east and west was steadily increasing. This became evident when various failed attempts were made to call back Delawares from the Ohio to rejoin their eastern kin in the Susquehanna Valley. The disconnection of west from east became permanent and increased the regional identity of the western bands, particularly with the sweep of historical events that entered the Ohio Valley to redefine the structure of once-decentralized Delaware Indians. Also throughout the Seven Years' War and during the brief uprising of Pontiac in 1763, powerful and influential leaders rose among the phratries of the western Delawares. In this time of crisis, the three animal tribes, who were in specific locations in the Ohio country, developed stronger political identities through the leadership of these influential men. As the alliance between Onondaga and Philadelphia once served as the catalyst for Delaware westward migration, the regional detachment of the western groups from those Delawares to the east, increased phratry cohesion and identity among the western groups. Isolation, as well as unity and a new sense of self (on a phratry level), served as powerful mechanisms in the establishment of the Delaware nation.

By the 1750s, British and Pennsylvania officials took notice of this new identity among the Ohio Indians, particularly the western Delawares. They quickly realized that they needed to get the Delawares out of the Ohio and coax them to come back under Covenant Chain control. 
To do so, they naively hoped that eastern Delawares could retain enough influence to persuade the westerners to return east, to move back across the Alleghenies to the Susquehanna.

Eastern Delawares shifted in and out of the Pennsylvania political spotlight. Earlier, when hostilities spread to the Susquehanna in the fall of 1755, the Quaker-led Pennsylvania assembly scurried to make a peaceful settlement with eastern Delawares, many of whom took an active role in the raids. They empowered the New Jersey Delaware (now relocated on the Susquehanna) known as Teedyuscung to unite the eastern tribes and proposed to meet with Pennsylvania officials at Easton, Pennsylvania in the summer of $1756 .{ }^{1}$ All in hopes of bringing the western Delawares back into the fold. Eventually, the western Delawares and their concerns became the focus of attention at the Easton talks.

In this "new-model" government of a coalition of Indian nations and communities from the Susquehanna and Wyoming regions, the Munsees and "two Tribes of the Delawares viz ... the Lenopi and Wanami," joined together "in a League" with "some of the Mohiccons" of the Hudson River and Susquehanna Shawnees. Teedyuscung selected a council of advisors and war captains. Charles Thomson, impressed by Teedyuscung's charisma, noted: "Soon afterwards a Number of straggling Indians, who lived up and down without any Chief, joined in and strengthened the Alliance." ${ }^{2}$ With Quaker support, "Teedyuscung soon saw himself at the Head of a very considerable body.", 3

To counter this Quaker-approved union of eastern Delawares and to maintain his authority, Sir William Johnson encouraged leaders of the Six Nations to send word to Delawares

${ }^{1}$ Champagne, "Delaware Revitalization Movement," 149; Newcomb, Culture and Acculturation, 50-53, 175; Goddard, "Delaware" in Trigger, ed., Handbook of North American Indians, 222; McConnell, A Country Between, 225.

2 Thomson, An Inquiry into the Causes, 83-84. Thomson had a favorable view of Teedyuscung. Many other observers during that period considered him to be a self-appointed King, with no hereditary claims to be a sachem among his people. Teedyuscung was born on the outskirts of Trenton, New Jersey in 1700. He and his father, called Old Captain Harris, were present at the "Walking Purchase." Because of the lack of game, Teedyuscung scrounged to make a living by making brooms and baskets for his white neighbors. He later migrated into the Lehigh Valley of Pennsylvania. He was baptized as a Moravian and given the Christian name Gideon. See James Thomas Flexner, Mohawk Baronet: Sir William Johnson of New York (New York: Harpers and Brothers, 1959), 168-169; Wallace, Teedyuscung, 2, 18-19, 45-47; Jennings, Empire of Fortune, 263.

${ }^{3}$ Thomson, An Inquiry into the Causes, 83-84. It is my opinion and not Thomson's that the Quakers supported Teedyuscung. 
at Tioga, on the North Branch of the Susquehanna, that the Covenant Chain alliance was displeased at the "unbrotherly Behaviour of their Nephews to the English. ..." ${ }^{4}$ They ordered the Tioga Delawares to send a council to Onondaga so that they could "have their heads shaked till they became sober," and "bore a larger [hole] in their Ears, and make them hear. ..." 5 Johnson met with these and other Susquehanna Indians at Onondaga.

Teedyuscung was deliberately excluded, as Johnson wanted to deal with a more pliable chief to represent Delaware affairs. Johnson's intent was to use eastern Delaware influence on the rebellious westerners and at the same time, maintain the preeminence of the Six Nations within the Covenant Chain. Johnson chose the ancient sachem Nutimus to act as chief for the eastern Delawares. Nutimus, the Munsee leader who had been chastised by Canasatego in 1742, was humbled in his old age. He eagerly acknowledged that his Susquehanna Delawares had been "deceived and deluded" by the French operating out of Fort Duquesne to take up arms against Pennsylvania. ${ }^{6}$ Nutimus added that the migrating Delawares were responsible for the breakup of eastern communities and the disregard for the authority at Onondaga. He contended that he could only speak for the eastern groups of Delawares and could only try to persuade the Ohio Delawares to reject an alliance with the French. ${ }^{7}$ Nutimus feebly promised Johnson that he would "use his utmost Endeavours to withdraw those of his Nation [the western Delawares] whom the French have seduced to go \& live in the Neighbourhood of Fort Duquesne." 8

In reality, there was a great political polarization between western and eastern Delawares. Eastern Delawares were quick to realize that their military actions could bring harsh retaliation as they were in close reach of Onondaga and Philadelphia. Western Delawares were willing to diplomatically exploit their devastating frontier raids and use them as a bartering chip in the

\footnotetext{
${ }^{4}$ Scarouady, in council with Governor Morris in Philadelphia, March 27, 1756, in MPCP 7: 67.

${ }^{5}$ Ibid., 7: 67; Newcomb, Culture and Acculturation, 50-53, 175; Goddard, "Delaware" in Trigger, ed., Handbook of North American Indians, 222; McConnell, A Country Between, 225.

${ }^{6}$ NYCD 7:96, 7:157; Hamilton, Sir William Johnson, 210.

7 Thomson, An Inquiry into the Causes, 91-94; Council at Fort Johnson, July 9, 11, 1756, in Johnson Papers 2: 499-500.

${ }^{8}$ Letter from William Johnson to General Abercromby, Fort Johnson, July 12, 1756, in MPCP 7: 194.
} 
imperial struggle between the British and the French. They also enjoyed a geographical distance that enhanced both a sense of regional identity and a spirit of defiance.

Johnson, much to the chagrin of the Six Nations, concluded the talks at Onondaga by "taking off the Petticoat or that invidious name of woman from the Delaware Nation [which had] been imposed on them by the 6 Nations from the time they conquered them. . ." 9 Deputies of the Six Nations told Johnson that they were not "properly authorized" by the Six Nations' Grand Council to release the Delawares from their tributary status. They "would make their reports $\&$ press it upon them" [the Grand Council]. ${ }^{10}$

Johnson's maneuver to control both the eastern Delawares and the Quaker Indian policy through the puppet leader Nutimus did not sit well with eastern Delawares. By symbolically removing the petticoat from the Susquehanna Delawares, Johnson gave them a degree of independence. He hoped that this move would assuage them and that they would be less apt to demand the reinstatement of Teedyuscung. However, Teedyuscung remained their choice over the "doddering old Nutimus." As the Ohio Delawares had once chosen Shingas as their King, despite the attempts of Six Nations' intervention, the easterners remained in support of Teedyuscung.

Sir William Johnson and the Six Nations brought the eastern Delawares to peace talks at Easton, Pennsylvania, in the summer of 1756 to officially gain their support and put an end to Delaware militancy on the Susquehanna. ${ }^{12}$ They also hoped that the eastern Delawares, locked in tight once again to the Covenant Chain, would have a beneficial influence on their western kin. Johnson begrudgingly accepted Teedyuscung as leader of the Susquehanna Delawares at the Easton conference.

Teedyuscung was unreliable in his diplomacy. At the Easton talks, the drunken leader claimed he was the king of ten nations, including the Six Nations. He also insulted several

${ }^{9}$ Sir William Johnson to Lords of Trade, July 17, 1756, in Edmund B. O’Callaghan, ed., The Documentary History of the State of New York 4 vols. (Albany: Weed, Parsons, and Co., 1856-1857), 2: 730; Sir William Johnson to Lords of Trade, July 17, 1756, in Pennsylvania Archives, John Blinn and William Egle, eds., 2nd Series, 12 vols. (Harrisburg: E.K. Meyers, State Printer, 1891), 6: 480-481. Also see NYCD 7: 119; Jennings, Empire of Fortune, 266.

${ }^{10}$ Johnson's comments, Albany, July 17, 1756, in NYCD 7: 119.

11 Jennings, Empire of Fortune, 272.

12 Ibid., 262-263. 
Iroquois chiefs and head warriors and postured as an all-powerful leader. He continually changed his accusations as to who was most responsible for alienating the Delawares. One time it was the Pennsylvania proprietors who had swindled his people out of their lands, another time the flattery of the "false hearted French King," or the intrusions of Connecticut settlers into the Wyoming Valley. ${ }^{13}$

At Easton, colonial observers criticized Teedyuscung and his band as "a belligerent bunch.” Teedyuscung walked about in a French-style coat, while Delaware women wore shirts made from the tablecloths of settlers killed on the Pennsylvania frontier. ${ }^{14}$ The Seneca councilor Newcastle, on behalf of the Six Nations, threatened to chastise those Delawares who were disobedient tributaries. He reminded the Delawares that they had betrayed the Six Nations and had become the "common Bawd" of the French, with whom they had considered a military alliance. The Six Nations then gave Teedyuscung a large belt and allowed him to speak, asserting that they had given him a "little Power" and that it would be "some Time" until he would be considered a "complete Man." 15

A year later, at the Easton talks of 1757, Teedyuscung claimed that the Six Nations made men of the Delawares once again, giving him the hatchet and authorizing him to make peace. He reminded the Six Nations that he had been empowered to bring the Indian nations together in a common bond of defense. He presented wampum belts to the Iroquois leader known as Anaquateeka and promised him "that whoever Strikes any one of us, Strikes all." ${ }^{16}$ He was not speaking the sentiments of western Delawares.

${ }^{13}$ Boyd, ed., Indian Treaties by Benjamin Franklin, 176; Wallace, Weiser, 523. Major William Parsons, an Indian agent, decribed Teedyuscung as a "lusty rawboned Man of fifty [-six] years who was haughty and very desirous of respect and command." It was noted that he could drink "three quarts or a Gallon of Rum a day without being drunk." See comments of Parsons in Boyd, ed., Indian Treaties by Benjamin Franklin, LXXVII. When Teedyuscung claimed he was king of all Indians, Sir William Johnson reacted with both understanding and criticism: "the Indian manner of speaking is indeed sometimes strongly figurative, but this is rant beyond what I ever met with." See Johnson Papers 2: 824-834.

${ }^{14}$ Pennsylvania Archives, 1 st series, 2: 724-725; MPCP 7: 683; Wallace, Teedyuscung, 105-106.

${ }^{15}$ Newcastle as interpreted by Conrad Weiser, Treaty of Easton, July 31, 1756, in Boyd, ed., Indian Treaties by Benjamin Franklin, 148.

${ }^{16}$ Teedyuscung to the Six Nations delegation at Easton, August 7, 1757, in MPCP 7: 710; Boyd, ed., Indian Treaties by Benjamin Franklin, 210. 
The Easton talks of 1756 and 1757 demonstrate a great deal about the growing clout of the Ohio Delawares and the attempts made by the Six Nations Confederation to diminish this power. Easton, as an eastern locale, symbolically represented Six Nations preeminence and control in colonial Pennsylvania Indian affairs. At the Easton talks, western Delawares were required to move "out of the weeds" from the region in which they enjoyed strength and influence, to come east into the domain of Iroquois supremacy. This in itself was a great diplomatic obstacle for Ohio Delawares to overcome.

At this time, eastern and western Delawares were moving in different political and diplomatic directions, conditioned by their divergent circumstances. Despite being given a degree of diplomatic freedom by Johnson, Delawares on the North Branch of the Susquehanna had to consider their proximity to the council fires at Onondaga. Teedyuscung and other eastern Delaware leaders were on a short diplomatic leash; independence was limited and constantly under the scrutiny of the Six Nations Confederation. They did not have the diplomatic freedom and geographical isolation of their western kin in Ohio country. To the west, in council with the French, Delaware chiefs claimed that they numbered five thousand people and that "should even twenty-thousand English come from Europe they [the Delawares] would exterminate them in the forests." 17 It was clearly evident that the Iroquois no longer dictated to the western Delawares and controlled the Susquehanna Delawares only by giving leaders such as Teedyuscung a little authority at Onondaga. ${ }^{18}$

Eastern and western Delawares acted independently of each other, linked only by a common language, religion, and kinship ties. If an eastern leader such as Teedyuscung made a promise to stop raiding, it meant nothing to those Delawares in the west. ${ }^{19}$ Western Delawares could adjust their attitude towards the Iroquois in concordance with the strength or weakness of

${ }^{17}$ De Bougainville in Hamilton, ed., Adventure in the Wilderness, 91.

${ }^{18}$ Charles Thomson in Jennings, Empire of Fortune, 263.

19 Jennings, Empire of Fortune, 262-263; Jennings, Fenton, eds., History and Culture of Iroquois Diplomacy, 54-55. Johnson had to be careful and not totally reduce Teedyuscung in stature as a Delaware leader. Teedyuscung and his warriors suited Iroquois and Pennsylvania needs by residing in the Wyoming Valley of the Upper Susquehanna. They kept Connecticut settlers out of this country, claimed both by the Six Nations and Pennsylvania. 
British presence west of the Alleghenies. ${ }^{20}$ There became a distinction between Susquehanna and

Ohio Delawares. ${ }^{21}$ Without a French presence east of the Alleghenies, eastern Delawares did not enjoy the luxury of such diplomatic adjustments.

A sober Teedyuscung knew his limitations regarding political influence. He cautioned the Pennsylvania Commissioners at Easton, "I would not have you mistake me, as if I meant that I could prevail on the Ohio Indians! I cannot tell them that they will leave off doing mischief." He pleaded that Pennsylvania make itself as "strong as possible" west of the Alleghenies. He also insisted that any wrong done on the east side of the Susquehanna was not the doing of his people but Ohio Delaware who passed over from the west to "do what Mischief they please.",22

Western Delawares refused to be bound by Teedyuscung's negotiations at Easton. Shingas and Pisquetomen, now living at the Kuskuskies, wanted to meet directly with the Pennsylvania government. They "had nothing to say to any treaty" made at Easton or any agreement negotiated by Teedyuscung. Western Delawares believed that Teedyuscung was too closely aligned with the interests of the Iroquois. The western leaders had nothing to do with him. ${ }^{23}$ Ohio Delawares rejected any colonial agreement made in the east that did not acknowledge their autonomy and right to a western homeland.

To the Delawares at western locales such as the Kuskuskies and Venango, Teedyuscung became emblematic of eastern Delawares who were shackled to a subservient position within the confines of a suffocating Covenant Chain. French officials sent wampum belts to Susquehanna Delawares and reminded them that in the east they wore petticoats and were tributaries of the Six Nations. They encouraged eastern Delawares to move west: "If you want Powder and Lead I

${ }^{20}$ Aquila, The Iroquois Restoration, 9. Nancy Shoemaker contends that the western Delaware relationship with the Iroquois during the Seven Years' War fluctuated back and forth from compliance to defiance. This relationship depended upon the political situation at the time. See Shoemaker, "An Alliance Between Men," 242-245; also refer to Appendix 2.

21 Thurman, "Delaware Indians in Ethnohistory," 97.

22 Teedyuscung at Easton, July 31, 1756, in Boyd, ed., Indian Treaties by Benjamin Franklin, 146.

${ }^{23}$ Comments of Christian Frederick Post, Aug. 18, 1758, in Jennings, Empire of Fortune, 394. 
have enough at Ohio; it lies there in heaps, and you may have what Quantity you please." ${ }^{24}$ The French promised Ohio Indians "rewards for Scalps and assurances of re-instating them in the Possession of the Lands" they had ceded between the Ohio and Susquehanna to the English. ${ }^{25}$ After 1755, the Pennsylvania Indian world underwent drastic change, as the Ohio country became the new center of Indian affairs in North America.

The Six Nations had unwittingly "put themselves out of business." By helping Pennsylvania exile Indians from the eastern part of the province and by turning over lands to the proprietors that they had taken from the Delawares, the Iroquois had "very little else to offer" Pennsylvania. They made themselves geopolitically obsolete, since they were originally assigned by Pennsylvania to control and police the province's Indians and the frontier. Anglo diplomats now turned their undivided attention to sway those western Indian nations on the periphery of the British west. $^{26}$

This was also a period in which western Delaware leaders were most concerned with the defense of their country, though they did not agree on how to attain any degree of security. During the Seven Years' War, and its aftermath with the rebellion of Pontiac, the Delaware animal tribes in the west evolved from groups bonded by ethnic and kinship ties into political divisions. $^{27}$ The various bands within the animal divisions slowly gained a sense of common goals. Delaware leaders, yet to be placed under a more-centralized national structure, were strongly concerned with the security of their individual phratry. War created a distinct tripartite division of Turtle, Turkey, and Wolf. Netawatwees ("Skilled Advisor") assumed leadership of the Turtle division, most of who resided at Saukunk in the Beaver Valley. Netawatwees became a highly respected Ohio Delaware leader and leaned towards support of the British. ${ }^{28}$ To the other extreme was Custaloga, principal leader of the Wolf tribe (Munsees) who lived in the

${ }^{24}$ The message of the Governor of Canada "to the Delawares \& no Indians else" as relayed to Governor Robert Morris by Scarouady at Philadelphia, November 8, 1755, in MPCP 6: 682-683.

25 "A Brief Narrative of the Incursions and Ravages of the French \& Indians in the Province of Pennsylvania," Philadelphia, December 29, 1755, in MPCP 6: 768.

${ }^{26}$ Aquila, The Iroquois Restoration, 191-194.

27 Champagne, "Delaware Revitalization Movement," 110-111; Becker, "Boundary Between Lenape and Munsee," 13.

${ }^{28}$ Champagne, "Delaware Revitalization Movement," 112. Netawatwees was also known as Newcomer. 
Upper Allegheny Country at Venango, close to the western Senecas. Custaloga and the western Senecas or Chenussio Senecas supported the French. The Seneca sachem Garistagee (“Mud Eater") served Custaloga as his chief adviser. ${ }^{29}$ The Turkey tribe, under the leadership of Shingas and Tamaqua, was located mostly at the Kuskuskies and at the rebuilt Kittanning town. Their council was sharply divided regarding the critical political concerns of alliances with European powers. ${ }^{30}$ Tamaqua did not follow the coalition of Unamis who left out of Kittanning in October of 1755, to raid on the Pennsylvania frontier. Tamaqua, along with another influential Turkey headman, Delaware George (Nenacheehunt), fully supported the British. ${ }^{31}$ Both had "not approved" the raids of Shingas and his followers from Kittanning, and were quite agitated at the group. Tamaqua "believed some of those who had [raided] were sorry for what they had done." He was willing to make amends to the English. ${ }^{32}$ Delaware George swore that his people had never waged war against Pennsylvanians. ${ }^{33}$

Shingas, once recognized as the leader of the western Delawares by the British and Six Nations, offered a different political position. He embraced an ideology that could be construed as "Delaware first." In 1755, pressured by the French and angry against Pennsylvania authorities, he launched vicious frontier raids on that province. Because of his defiant stance, he was eventually removed by the British as the client chief and replaced by Tamaqua. ${ }^{34}$ Shingas did not necessarily support the French, but his political views were structured upon his increasing vision of a Delaware nation-- a nation free of Anglo or Six Nations' political and territorial encroachments.

He and other leaders were also entrenched in the reality that the three tribes of Delawares needed to make the right decision regarding alliances in the evolving imperial struggle for the

${ }^{29}$ Hunter, "Sub Divisions of the Delawares," 33-34; William Hunter, "Provincial Negotiations with the Western Indians, 1754-58," Pennsylvania History, Quarterly Journal of the Pennsylvania Historical Association 58 (July 1951): 5.

${ }^{30}$ Champagne, "Delaware Revitalization Movement," 112-113.

${ }^{31}$ Hunter, "Sub Divisions of the Delawares," 33-34; Hunter, "Provincial Negotiations with the Western Indians," 5-6; Goddard, "Delaware" in Trigger, ed., Handbook of North American Indians, 223.

${ }^{32}$ Joseph Fox, Pennsylvania Commissioner in council at Carlisle, Pennsylvania, Jan. 13, 1756, in MPCP 6: 781; Tamaqua in council with Gov. Morris, Jan. 13, 1756, in ibid., 6: 781.

${ }^{33}$ Delaware George at Venango, July 19, 1757, in NYCD 7: 286.

${ }^{34}$ Hunter, "Sub Divisions of the Delawares," 33-34. 
Ohio. Throughout the Seven Years' War, the western Delawares remained uncommitted in taking a side, whether on a phratry or national level. George Croghan, as a deputy to Lord Loudon, the British commander-in-chief in America, correctly summed up the situation on the Ohio. He believed that no more than three hundred French were garrisoned at Fort Duquesne and that the Ohio Delawares and Shawnees along with the Mingos were "divided amongst themselves, one Half of each Tribe going down [the] Ohio to where the Lower Shawanese are settled, on the Scioto [River], and the other Half were determined to go off to the Six Nations," to remain in the British sphere. ${ }^{35}$

This non-committal status was a trait of the Delaware tribes during this conflict. The British and French actively courted their leaders for support. It was rumored that the Turkey council met at the mouth of Beaver Creek to discuss "demolishing" the French garrison of Fort Duquesne. Shingas, to get back in the good graces of the British, was prepared to "destroy the Inhabitants." 36 Nothing came of this threat. The French had promised western Delawares "that if they would assist them they would repossess them of their native Country and bring the [Pennsylvania] people under their command."37 The governor-general of New France, the Marquis Pierre di Rigaud de Vaudreuil, believed that French military presence would overawe those Ohio Delaware tribes, who still clung to supporting the British: "This sight of this army, which consists of about 9000 men, will give these Loups (Delawares) nothing but an exalted idea of the French power and strengthen the confidence they are beginning to have in us."

Western Delawares, for the most part, were not totally convinced of French power. Shingas, Pisquetomen, and others involved in the frontier raids of 1755 and 1756, realistically weighed this success as a short-term victory. On the periphery of Pennsylvania, the Turtle, Turkey, and Wolf tribes of Delawares individually became established as formidable forces that Pennsylvania and the Six Nations could not ignore. Collectively the Turtle-Turkey tribes, however, were well aware that a war against the British was not in their best interests. Also,

35 George Croghan to Sir William Johnson, March 29, 1757, in Boyd, ed., Indian Treaties by Benjamin Franklin, 169.

36 "The Examination of two Indian Prisoners taken and brought to Fort Lyttleton by the Cherokees," Fort Lyttleton, May 12, 1757, in MPCP 7: 31.

${ }^{37}$ Richard Peters, January 1755, in Merrell, Into the American Woods, 232.

${ }^{38}$ Marguis de Vaudreuil to French minister, July 13, 1757, in Stevens and Kent, eds., Wilderness Chronicles, 107-108. This figure of 9,000 was greatly exaggerated. 
while Custaloga and the Wolf Delawares were physically separated from the Turtle and Turkey Delawares on the Ohio, they remained cautious in establishing a military alliance with the French. The Wolf-Munsee division relied upon the western Senecas to handle all their discussions with the English. The Wolf phratry of the Upper Allegheny region, slowly "established a symbiotic relationship with the French garrisons in the area, supplying food and labor in exchange for trade goods and cash., 39

From 1756 to 1758 the core of Unami-speaking Delawares in the west sought a peaceful solution rather than to plunge into a disastrous war with the British. Both Tamaqua and Shingas were willing to support the British on the condition that the Turkey tribe would be given a prominent status over the other Delaware divisions. Tamaqua agreed to accept a "token Iroquois hegemony" in the Ohio and to keep his warriors from joining the French. He also hoped that by doing so, he would elevate his status among all Delaware headmen. ${ }^{40}$ Tamaqua reminded the British that the French had treated the Delaware people "kindly, in every respect" and hoped that the British would "take the same method." ${ }^{41}$ He told Croghan that the "governor of Fort Duquesne" had offered his Delawares the hatchet. Tamaqua refused until he gained advice from the Six Nations. But he contended that a group of Senecas on their way south to raid the Catawbas were also at Fort Duquesne. These warriors offered the "French hatchet to the Delawares and Shawonese who received it from them and went directly against Virginia."42

The Marquis de Vaudreuil noted that the Delawares were playing sides--perhaps as a strategy rather than indecisiveness. A Delaware delegation told a French emissary that they were "firmly resolved to abandon the English forever." Later de Vaudreuil was informed that the same delegation had "gone in truce [to the English] to seek peace," or at least a better deal. ${ }^{43}$

Eventually Ohio Delawares left their French allies when it became apparent that the French could not supply the Delawares with the steady flow of the trade goods (firearms,

39 McConnell, "Search For Security," 152-153.

${ }^{40}$ Tamaqua to Croghan in council, Jan. 13, 1756, in MPCP 6: 781; White, The Middle Ground, 250-253.

41 "The Journals of Post" in Thwaites, ed., Early Western Travels, 1: 277-278.

${ }^{42}$ Tamaqua to Croghan in council at Carlisle, Jan. 13, 1756, in MPCP 6: 781; White, The Middle Ground, 250-253.

${ }^{43}$ Marquis de Vaudreuil to the French minister, July 12, 1757, in Stevens and Kent, eds., Wilderness Chronicles, 100. 
powder, tools, clothing) that they had become dependent upon. And those French goods that found their way into Indian towns did not have the quality of the English products. ${ }^{44}$

As French presence in the Ohio decreased, western Delawares who had accepted the French hatchet, sought to alter allegiances. This shift began when a group of Delaware warriors failed in their attack against the British at Fort Ligonier in western Pennsylvania in October of 1756. This failed siege became a turning point for the British war effort in the west and slowly disillusioned the Ohio Delawares who supported the French. Also the British were regrouping to prosecute the war at a more ferocious pace under the auspices of William Pitt, newly appointed Secretary of State for the British Crown in December 1756. By the spring of 1758, Brigadier General John Forbes initiated a military expedition with a goal to push from Carlisle, Pennsylvania, and "cut a new wagon trail" westward. Forbes, along with Swiss-born Colonel Henry Bouquet, planned to move one hundred miles across Pennsylvania and remove the French from the Ohio by taking Fort Duquesne and maintaining an English military garrison at the forks. $^{45}$

Forbes chose to avoid the mistakes of Braddock in his 1755 march to the Ohio. Rather than alienate the Ohio Indians, as did Braddock, Forbes used Teedyuscung and Quaker merchant Israel Pemberton to help pave the way for peace negotiations with the Delawares. Forbes hoped that the efforts of Teedyuscung and Pemberton would wear down the militancy of the French Indians at the forks. This was a controversial plan, as Forbes was aware that Sir William Johnson and the Iroquois did not favor an "independent standing" of the Delawares in the west. Forbes went over Johnson's head and with the assistance of Pennsylvania's new governor, William Denny, arranged for Tamaqua and Pisquetomen to come to Philadelphia to discuss peace. ${ }^{46}$ Both Delaware leaders sought to make peace with the English. Not to be outdone, Sir William Johnson sent Croghan with wampum belts to the "scattered Delaware Indians on the

${ }^{44}$ Weslager, The Delaware Indians, 236-237.

${ }^{45}$ Fred Anderson, Crucible of War: The Seven Years' War and the Fate of Empire in British North America, 1754-1766 (New York: Alfred A. Knopf, 2000), 257-258. Also see Sipe, Indian Wars of Pennsylvania, 387-391; O’Meara, Guns At The Forks, 188-193; West, ed., War For Empire, 47-57. For more on William Pitt and the British plans of war, see Jennings, Empire of Fortune, 354-363.

${ }^{46}$ Anderson, Crucible of War, 268-270; Theodore Thayer, Israel Pemberton, King of the Quakers (Philadelphia: University of Pennsylvania Press, 1943); Jennings, Empire of Fortune, 393-394. 
Ohio to invite them back to their former Settlements" and to meet with Governor Denny, the Susquehanna Delawares, and "Deputies of the Six Nations." 47

Encouraged by the prospect of peace, Denny enlisted Christian Frederick Post, a Prussian-born Moravian missionary; to accompany the Delaware leaders back to the Ohio and continue negotiations. Post was an excellent choice. He was a skilled frontiersman and a trusted friend of the Delawares. (He also had two Delaware wives.) Post was instructed by Governor Denny to offer amnesty to all Delawares who had participated in frontier raids against Pennsylvania if they would now support the British. ${ }^{48}$ Post and Pisquetomen reached Shingas and Tamaqua at the Kuskuskies by the middle of August of 1758. Post assured Tamaqua and the other leaders that the English wanted peace. At the Kuskuskies, Shingas shielded Post from a French captain and fifteen of his men. Having eluded the French, Post continued down the Ohio to address other Delawares and their Shawnee and Mingo allies. Though well received by the Indians, Post had to be protected from the French by Pisquetomen and his warriors. On August 26, he spoke to a large group of Ohio and Great Lakes Indians outside of Fort Duquesne as French officers watched. ${ }^{49}$

As Post moved about the region, Forbes received word from Netawatwees of the Turtles, Custaloga of the Wolf clan, and Keekyuscung, a spokesman of the Turkey tribe, that they were willing to "return to their old habitations," and move away from the French at the forks of the Ohio. They told Forbes that they were "heartely weary of the warr." ${ }^{, 50}$ This message from the principal spokesmen of all three phratries demonstrates that a consensus was slowly taking form among the western Delawares. These leaders realized that the British were about to take control of the Ohio Valley.

By 1758 loyalties wavered as the war turned in favor of the British. From July to December, Post met with Delaware chiefs from all three tribes to "prevail on them to withdraw

${ }^{47}$ Johnson to Governor Francis Bernard, July 19, 1758, in Johnson Papers 2: 875.

${ }^{48}$ Anderson, Crucible of War, 270-271; C. Hale Sipe, ed., Fort Ligonier and Its Times (1932; reprint, New York: Arno Press and The New York Times, 1971), 95.

${ }^{49}$ Anderson, Crucible of War, 270; Sipe, Fort Ligonier, 89; Walter C. Champion, Jr., "Christian Frederick Post and the Winning of the West," The Pennsylvania Magazine of History and Biography 104 (July 1980): 318-319.

${ }^{50}$ Gen. Forbes to Col. Bouquet Aug. 2, 1758, in Sylvester K. Stevens, Donald H. Kent, et al; eds., The Papers of Henry Bouquet 5 vols. (Harrisburg: Pennsylvania Historical and Museum Commission, 1951-), 2: 303-304. 
from French interest." ${ }^{, 51}$ At the Kuskukies, Post met with the civil chiefs and war captains of the Turkey tribe. Shingas and Tamaqua assured Post of their friendship for the English. However, they reminded him that they did not have the authority to speak for all other western Indians who had "united in a body" against the British. ${ }^{52}$ Post then met with Koquethagechton (White Eyes) and Gelelemend (Killbuck), the principal war captains of the Turtle tribe at Saukunk. He noted that these two warriors, once very hostile to Post's overtures of peace, now "received [him] very kindly" and "apologized for their former rude behaviour." White Eyes and Killbuck then escorted Post back to the Kuskuskies for a great council meeting. ${ }^{53}$ Delaware George reiterated the sentiments of the western Delawares, and at the same time, demonstrated his inability to speak for the other Ohio nations (Shawnees and Mingos) when he addressed Turtle and Turkey leaders and Post's party on September 4, 1758:

Look, Brothers, we are here [on the Ohio] of three different nations. I am of the Unamawa [Unami] Nation . . . I am sorry that I should make friendship with the French against the English. I now assure you my heart sticks close to the English interest. ... ${ }^{54}$

It appears that Tamaqua had persuaded Shingas and his followers to move into a proBritish footing. Shingas said that the Delawares joined the French reluctantly despite the fact that traders had told them that both the English and French "intended to join and cut all the Indians

${ }^{51}$ Christian Frederick Post in "Post's Journal, 1758," in Rupp, ed., Early History of Western Pennsylvania, 75; Also see "Journal of Frederick Post, 1758," in Pennsylvania Archives, 1st series, 3: 520-549.

${ }^{52}$ Comments of Turkey delegation to Post, August 18, 1758, in Early Western Journals, 1748-1765 by Conrad Weiser, 1748; George Croghan, 1750-1765; Frederick Post, 1758; and Thomas Morris, 1764, ed., Reuben Gold Thwaites, separate publication from "Early Western Travels: 1748-1846," (Lewisburg, Pennsylvania: Wennawoods Publishing, 1998), 198-199.

${ }^{53}$ Post at Saukunk, August 28, 1758, in ibid., 210-211. Various writers have classified White Eyes as a member of the Turkey lineage. I rely on the observations of John Heckewelder who contends that White Eyes belonged to the Turtle tribe of Delawares. See Heckewelder, An Account of the Indian Nations, 139. White Eyes was also referred to as Grey Eyes and in several documents he was referred to as "Cockquaukeheton."

${ }^{54}$ Delaware George, September 2, 1758, in Early Western Journals, ed., Thwaites, 220. 
off" from the trade goods that his people needed to survive. ${ }^{55}$ He asked the British if they would remove back east across the Appalachians and wait until the Delaware tribes could meet in council with the other Indian nations to negotiate for a peace throughout the Ohio. The Delawares would then invite the British back to " build a trading house." 56 This trading house could only be realized after the French were driven from point of the three rivers. Pennsylvania, through the mediation of Post, agreed to relinquish its claims to lands west of the Appalachians. The Delawares were also assured that General Forbes would not molest their villages when his British and American forces assaulted Fort Duquesne. ${ }^{57}$ The diplomacy of Post and, particularly Pisquetomen, helped to weaken the French influence in the Ohio and bring all Unami Delawares back into the British orbit. ${ }^{58}$

As the combined colonial and British army under Forbes pushed and hacked its way to the forks of the Ohio, an Indian congress met once again with colonial officials at Easton. In attendance on October 8, 1758 were representatives from Pennsylvania, New Jersey, and New York along with Teedyscung and the eastern Delawares, the Six Nations, Nanticokes, Mahicans, and Wappingers. A small western Delaware delegation headed by Pisquetomen and his council arrived a few days later. ${ }^{59}$ Before this western delegation arrived, the Seneca chief Tagashata, out of the affinity his people had with Wolf Delawares, assumed to speak for the western Delawares. He told New Jersey governor Francis Bernard that the Munsees and "three other different Tribes of that Nation, [he possibly included Mahicans as part of the Delawares] have, at last, listened to us, and taken our Advise, and laid down the Hatchet" they had used against the

55 Shingas in "Post's Journal, 1758," Rupp, ed., Early History of Western Pennsylvania, 92.

56 Shingas in ibid., 123.

${ }^{57}$ Sylvester Stevens and Donald Kent, eds., The Papers of Colonel Henry Bouquet 19 vols. (Harrisburg: Pennsylvania Historical and Museum Commission, 1940), 2: 38-39.

${ }^{58}$ For more on the diplomatic mission of Post and Pisquetomen see Merrell, Into the American Woods, 242-249; Champion, "Christian Frederick Post," 308-325.

${ }^{59}$ Anderson, Crucible of War, 275; Jennings, Empire of Fortune, 396-397. 
English. ${ }^{60}$ Tagashata also apologized for a band of eastern Delawares, who under Captain Bull (Teddyuscung's son) were goaded by the French to commit violent raids on the Susquehanna. ${ }^{61}$

Teedyuscung marred the talks at Easton when he came to a session drunk and belligerent. He, like Tagashata, attempted to speak for all Delawares, even though Pisquetomen had yet to arrive. Teedyuscung also chastised the Iroquois for their attempts to dominate his people. He claimed he and not the Iroquois had the power to make the Delawares accept the peace belts. At Easton, Teedyuscung was caught in the middle of colonial rivalries. While the proprietors condemned the actions of the eastern Delawares, the Quakers championed Teedyuscung and rationalized Delaware raids as retaliation for such land frauds as the Walking Purchase in $1737 .{ }^{62}$

After Teedyuscung's drunken tirade, he had "his wings clipped." denounced the authority of Teedyuscung and questioned who had given him that power. Nichas of the Mohawks was the most vehement. He wondered if Governor Denny, "or perhaps the French" had elevated the status of Teedyuscung. ${ }^{64}$ Denny came to Teedyuscung's and his own defense, when he maintained that the Delaware leader "never assumed authority" over ten nations and that he had spoke of the Iroquois with deference "as his uncles and superiors." 65 Denny also asserted that Teedyuscung claimed to be a "Chief man for the Delawares, but only as a Messenger for the United Nations," or the ten eastern tribes. ${ }^{66}$

The Easton Conference once again changed the political environment of Pennsylvania and its Indians. The proprietors gave back to the Iroquois all land "Westward of the Allegheny or Appalaccin Hills" purchased at Albany in $1754 .{ }^{67}$ Governor Denny promised to restrain English

${ }^{60}$ Tagashata to Governor Bernard in Easton, Oct. 12, 1758, in Boyd, ed., Indian Treaties by Benjamin Franklin, 219.

${ }^{61}$ Ibid., 219.

62 Wainwright, George Croghan, 148-149.

63 Ibid., 148-149; MPCP 8: 190-192.

${ }^{64}$ Nichas to Indians and governors at a private conference during Easton talks, Oct. 15, 1758, in MPCP 8: 190. Other principal leaders of the Six Nations who denounced Teedyuscung included, Tagashata (Seneca), Assarandonguas (Onondaga), Tokaaio (Cayuga), and Thomas King (Oneida).

${ }^{65}$ Ibid., 8: 190-192.

${ }^{66}$ Governor William Denny in conference at Easton, Oct. 16, 1758, in MPCP 8: 192; Boyd, ed., Indian Treaties by Benjamin Franklin, 226.

${ }^{67}$ Governor Denny to Six Nations delegation at Easton, Oct. 20, 1758, in MPCP 8: 204. 
settlements west of the Alleghenies, an action later made official policy by the Royal Proclamation Line of 1763. Peace was made between eastern Delawares and Pennsylvania, and western Delawares agreed to withdraw from French influence and not to assist in the defense of Fort Duquesne. ${ }^{68}$ By this time the majority of Susquehanna Delawares were attached to the British, except for bands of Munsees living on the west branch of the Susquehanna, who had never been controlled by Teedyuscung. ${ }^{69}$

In a sense, with land being returned to the Iroquois, the Covenant Chain was extended, but not necessarily strengthened, west of the Alleghenies. Once again, the Iroquois faced the difficulty of asserting their rights as owners of the land and overlords of their tributaries. After Easton, the temporary independence enjoyed by eastern Delawares had ended. Teedyuscung, no longer needed as a mediator between Pennsylvania and the Ohio tribes, became expendable. ${ }^{70}$ The Iroquois once again claimed superiority over the eastern Delawares. They were, however, not willing to push their luck and attempt dominance over the Ohio tribes. The Iroquois lost the right to speak for the western Delawares. As the army of John Forbes approached Fort Duquesne, the British treated directly with the Delawares, ignoring Iroquois pretensions as territorial overlords. $^{71}$

The Easton conference of 1758 symbolized a new prestige for western Delaware leaders in the geopolitical environment of British America. Pisquetomen and his council brought a message from Ohio Delawares that demonstrated solidarity and a need for Delawares to reestablish a positive relationship with the English and Pennsylvania. Pisquetomen and Post delivered a statement of consensus in wampum belts from "Captains and Councellers"--all

\footnotetext{
${ }^{68}$ Fenton, Great Law and Longhouse, 509; Jennings, Empire of Fortune, 402.

${ }^{69}$ Croghan to Sir William Johnson, March 29, 1757, in Boyd, ed., Indian Treaties by Benjamin Franklin, 169.

${ }^{70}$ Without a following, Teedyuscung in an emotional moment as a forgotten man, lamented to the Six Nations delegation: "I sit here as a Bird on a Bow [Bough]: I look about and do not know where to go. ..." See Teedyuscung to Six Nations delegation at Easton, Oct. 20, 1758, in MPCP 8: 201, 203; Wallace, Teedyuscung, 192-207.

${ }^{71}$ Anderson, Crucible of War, 277-278; Jennings, Empire of Fortune, 402; Jennings, Fenton, eds., History of Iroquois Diplomacy, 191. Jennings contends that the Iroquois would not claim land rights in the Ohio until Easton solidified their territorial rights and until Forbes and his army were at the gates of Fort Duquesne. In other words the Six Nations needed to be reassured of British commitment in the Ohio before they would "push pretensions of superiority" over Ohio Indians. See Jennings, Fenton, eds., History of Iroquois Diplomacy, 400-402.
} 
principal civil and war leaders of the western Delawares. The list of marks included Tamaqua, Shingas, and Delaware George of the Turkey tribe, Captain Kill Buck (Bemineo), a Wolf war captain and the father of young Killbuck, and White Eyes, the prominent Turtle war captain, among other leaders. Captain Kill Buck appeared regularly at various diplomatic talks with the British during the fall of 1758. With the presence of this prestigious war captain, it became apparent that the long-isolated Wolf tribe was slowly becoming part of the coalition that had been established among the Turtle and Turkey tribes. All western Delawares sought to renew the "Peace and Friendship" that had existed in the past with Anglo-America. The Delawares asked the British to make a peace that would be acceptable to the Delawares beyond the Alleghenies and that if they did so, their leaders would relay the word to all Indian nations of the Ohio and Great Lakes. $^{72}$

Clearly the western Delawares were seeking peace and were not dependent upon the Iroquois to broker a deal for them. Governor Denny saw a great opportunity to achieve a peace on the Ohio that would benefit both Pennsylvania and the British. The governor differentiated between Teedyuscung's Delawares, referred to as the "United Nations" of Indians, and Ohio Delawares, who he called “our Brethren.” Denny responded to Pisquetomen's message by inviting an Ohio Delaware delegation to "come to Philadelphia ... to [the] Old Council Fire, which was kindled when we first saw one another. . . " By referring back to the days of William Penn, Denny hoped to reestablish the positive relationship of the past. ${ }^{73}$ He also promised the Delawares that if they restrained their warriors on the frontier not to attack settlements, not to molest Forbes' army, and to remain clear of Fort Duquesne, they would be safe from the British military. Denny assured them that the army was sent not to punish these Indians who had opposed the King of England (called "lost children") but to "Chastise the French."74

72 A message from western Delawares to Governor Denny at Easton, Oct. 13, 1758, in MPCP 8: 188-189. Kill Buck had also been actively involved in talks with Christian Post, one month earlier. Also see "Journal of Frederick Post, 1758," in Pennsylvania Archives, 1 st series, 3: $565-566$.

${ }^{73}$ Governor Denny in response to Pisquetomen's message, Easton Oct. 20, 1758, in ibid., 8: 207.

74 Ibid., 8: 207. Denny also guaranteed a "Clear and open Road" for all Indians in alliance with the western Delawares, to come to Philadelphia. Denny also encouraged estranged Delawares to once again be part of the "Chain of Friendship" (in reference to Covenant Chain.) 
Though the Ohio Delawares sought peace, this was not docility. Delawares were adamant in defending their independence and their new homeland beyond the Alleghenies. As western Delawares refused to give ground at Easton in 1758, they defied any attempt of the Six Nations to reassert overlord dominance in the Ohio. A delegation visited a Chenussio Seneca town and openly told them "We have been once Women, and ashamed to look down at our Petticoats, but as you have taken off our Petticoats, and encouraged us to quarrel with the English, we are determined to never submit to that ignominious State while there is one of us alive." ${ }^{75}$ Hugh Mercer, the Scottish physician who was a lieutenant colonel under Forbes, informed the General that a combined force of Shawnees and Delawares had the capability to destroy the Six Nations. He believed that only the "very powerful aid of the British could prevent this annihilation." 76

Keekyuscung, a companion of Pisquetomen, warned Post that "all the [Ohio Indian] nations had jointly agreed to defend their hunting place at Alleghenny." He wanted the English not to settle there but to "draw back over the mountains." He was opposed to any form of English settlement and told Post that a banning of settlements would be the only way to win over the loyalty of the Ohio Delaware tribes. Post was to express these hopes to Forbes. ${ }^{77}$

As Forbes's army approached the forks of the Ohio, the Indian allies were deserting the French. At the Kuskuskies, the Delawares received a war belt from Captain Francois-Maria Lignery, the French commander at Duquesne. They refused the belt, threw it to the ground, and kicked it "as it were a snake." They informed the messenger "We have often ventured our lives for him [the French]; and had hardly a loaf of bread" to show for their loyalty. ${ }^{78}$

On November 26, de Vaudreuil reported that the British met with Pisquetomen and Keekyuscung at the Kuskuskies and asked them to "forget the past, to renew their ancestors'

In this fashion, Denny covered all grounds by appeasing both the Ohio tribes and the Six Nations. See MPCP 8: 213.

${ }_{75}$ Delaware delegation to Senecas in Fenton, Great Law and Longhouse, 500-501,

${ }^{76}$ Hugh Mercer to General John Forbes, Jan. 8, 1759, in Papers of Henry Bouquet 3: 25; Anderson, Crucible of War, 283.

${ }^{77}$ Keekyuscung to Post, Nov. 29, 1758, in "The Second Journal of Christian Frederick Post Oct. 25, 1758 to Jan, 10, 1759," in Rupp, ed., Early History of Western Pennsylvania, 120.

78 Anderson, Crucible of War, 282; “The Journals of Post" in Thwaites, ed., Early Western Travels, 255-256. The French force had dwindled to 300; many of these men were sick and not fit for duty. All of the Indians, including a small group of Delawares, deserted the French at Duquesne. Lignery ordered the torching of Fort Duquesne and withdrew his men north, to Fort Machault (Venango). See O’Meara, Guns at the Forks, 209. 
alliance with them, to let their entanglement with the French become void. ..." ${ }^{79}$ The Turkey leaders told the British negotiators that to "hear their speeches, they must withdraw to the other side of the mountains, and leave their lands free." Without this understanding, the Delaware tribes would never strike an alliance with Anglo governments. De Vaudreuil reported to the French minister that the Kuskusky Delawares told the English that they and other tribes would not be driven from the Ohio, for it "belonged to them from its source to its mouth." 80

At this time the Delawares had emerged as the influential spearhead within the bloc of western Indian nations. In 1759, Colonel Henry Bouquet described the Delawares as a "Warlike Nation, living on the Ohio, Beaver Creek, and several other Branches of the Ohio, and high up the Susquehanna" river region. He noted that in their current state, western Delawares comprised of about 300-400 warriors. These numbers were changing as they "were collecting their People together" on the Ohio to be a force with which to be reckoned. ${ }^{81}$

Delawares also hoped to regain the prominence they once enjoyed in Pennsylvania as peacemakers. The British looked upon Shingas and Tamaqua as influential men who could sway western Indians from the French fold. An intelligence report from Hugh Mercer in March 1759, noted that western and Great Lakes Indian delegations were visiting the Kuskuskies to hear the words of Delaware leaders. Mercer was optimistic that these Indians would "follow the Example of their Grandfathers the Delawares." 82 Delaware leaders were prepared to make peace with the British and to enforce that peace as their national policy. Their decision was also hurried by the dramatic events that transformed the Ohio region and forever altered Delaware history.

The fall of Fort Duquesne was a turning point of the Seven Years' War in the Ohio country. The English quickly accelerated their goals at gaining a total peace in the Ohio, free of the instigations of the French. In July and August of 1759 George Croghan, as Sir William Johnson's "Deputy Agent" in the Ohio, and Colonel Hugh Mercer, the commandant in charge of the construction of Fort Pitt (to be built at the point on the three rivers where Fort Duquesne once stood), met with the Delawares and other western Indian nations to secure a lasting peace.

${ }^{79}$ Marquis de Vaudreuil to French minister, March 30, 1759, in Stevens and Kent, eds., Wilderness Chronicles, 140-141.

${ }^{80}$ Ibid., 141.

${ }^{81}$ Colonel Bouquet's "Descriptions of Western Indians," 1759 in Papers of Henry Bouquet 3: 405.

${ }^{82}$ Mercer's Report, March 18, 1759, in MPCP 8: 311. 
Croghan in particular, hoped to re-establish himself with the Ohio Delawares because he wanted to protect his "land-speculating-interests." ${ }^{83}$ Western Delawares assembled a strong delegation of civil and war leaders. The Turkey tribe had a major presence at these Fort Pitt talks.

Representing the western Delawares were Tamaqua, Shingas, Delaware George, Keekyuscung, and Captain Johnny (Welepachtschiechen), all of the Turkey phratry. Also in attendance at the newly constructed fort, was the Turtle war captain White Eyes, and a group of Wolf war captains including Captain Kill Buck and Captain Pipe (the nephew of Custaloga). These leaders were committed in seeking the establishment of trading posts in the Ohio, but all were opposed to Anglo settlements and permanent British garrisons in what they perceived to be Indian country. Also present at the talks was a small group of Iroquois and Shawnees. ${ }^{84}$ However, Delaware interests and concerns were the focus point of these peace talks.

An official peace was concluded on September 13, 1759 when Captain Pipe met with Croghan. Pipe told him that he was carrying a message from Tamaqua and other principal Delaware leaders that they, as holders of the wampum belts of all Ohio Indians, had "forwarded all the Speeches entrusted to his [Croghan's] Care by the western Indians to the Six Nations \& Susquehanna Indians." He then requested that Croghan give him wampum belts to enable him to convert more Indians "for the good of the English interests." Captain Pipe also "delivered up" two white boys who had been taken captive in Lancaster County. ${ }^{85}$

By October 1759, French strength in the west dwindled to 500 starving men at Fort Detroit together with a small group of diehard Great Lakes Indians who prepared themselves to "fall with their [French] Father." 86 Peace came to the Indian west when Canada fell to the British in September 1760. Britain now would not just have to pacify and govern the Great Lakes

${ }^{83}$ Anderson, Crucible of War, 327.

84 "At a Conference held at Pittsburgh on the 5 th of July, 1759," in MPCP 8: 383-384. Pipe's Delaware name was Kageshquanohel meaning "Maker of Daylight." The Six Nations called him Hopocan meaning "Calumet" or "Tobacco Pipe." Bouquet referred to Captain Pipe and other Wolf leaders as "warriors of the Cuscuskees." See Papers of Henry Bouquet 3: 507; Weslager, The Delaware Indians, 64, 298-299.

${ }^{85}$ George Croghan, Pittsburgh, July 8, 1759, in MPCP 8: 385, 389; George Croghan, Sept. 13-14, 1759, in “George Croghan's Journal 1759-1763” edited by Nicholas B. Wainwright, The Pennsylvania Magazine of History and Biography 71 (Oct. 1947): 324, 351.

${ }^{86}$ Comments of an English prisoner to a Wyandot, who then passed the message on to Croghan at Fort Pitt in “George Croghan's Journal," ed., Wainwright, 353. 
and Ohio Indians. They now also wielded authority over a vast number of Canadian tribes. The Ohio country, in particular, became redefined as an extended part of Britain's "greatly enlarged empire." 87

Delawares reluctantly supported the restoration of the British in the Ohio. In reaction to the presence of the British military, Delawares, at the invitation of the Wyandots, started to leave the Allegheny River town of Kittanning and the Beaver Valley communities of Saukunk and the Kuskuskies to move west to the Muskingum / Tuscarawas country. The Wyandot council promised the Delawares that they would "never sell the ground under their feet to the White People" as the Six Nations had done in Pennsylvania. ${ }^{88}$

Despite this "westward relocation" of what could be considered the core of the Delaware nation, the majority of Munsee-Wolf people remained in the Upper Allegheny at Venango. The Wolf tribe, yet to join the main body of Delawares, still remained close to their western Seneca allies. The Unami-speaking Turtle and Turkey Delawares moved across the Ohio to establish new towns and a central council fire in the Muskingum River valley of the Upper Ohio. ${ }^{89}$ The leaders of these Unami groups extended invitations to the Susquehanna Delaware and Munsee

${ }^{87}$ McConnell, A Country Between, 146; Jack M. Sosin, Whitehall and the Wilderness: The Middle West in British Colonial Policy, 1760-1775 (Lincoln: University of Nebraska Press, 1961), 46.

${ }^{88}$ John Heckewelder, A Narrative of the Mission of the United Brethren among the Delaware and Mohegan Indians, from its Commencement, in the Year 1740, to the Close of the Year 1808 Edited by William Elsey Connelley, (1820; reprint, Cleveland: The Burrows Brothers Company, 1907), 230; Paul A.W. Wallace, ed., The Travels of John Heckewelder in Frontier America (Pittsburgh: University of Pittsburgh Press, 1985), 95-98. Originally published as Thirty Thousand Miles with John Heckewelder (Pittsburgh: University of Pittsburgh Press, 1958). The Iroquois previously had given the Wyandots the country near the west end of Lake Erie and the Ohio Valley between the Ohio River and the Miami River. The Wyandots became proprietors of this region and granted the Delawares and Shawnees the right to settle in that region. The Wyandots had become overlords of Ohio tribes--similar to the relationship between the Delawares and the Iroquois in the east. Ironically in 1843, the Wyandots were resettled in Kansas Territory on a tract of land (at the mouth of the Kansas River) purchased from the Delawares for an exuberant price of 48,000 dollars. The Wyandots complained that at one time, the Delawares had nowhere to go and they were given land in the Ohio. The Delawares now had an opportunity to repay the kindness of the Wyandots and instead gouged them. See the notes by William Connelley in Heckewelder, Narrative of the Mission, ed. Connelley, 273.

${ }^{89}$ McConnell, A Country Between, 208-209; Goddard, "Delaware" in Trigger, ed., Handbook of North American Indians, 222. As part of this migration, the majority of northern Unamis remained behind on the north branch of the Susquehanna, to eventually be subsumed as 
speakers of the Wolf tribe to join them on the Muskingum. Most importantly, the "nucleus of the emergent Delaware tribe" had been planted on the Muskingum. ${ }^{90}$

By the 1760s, the Ohio country had been transformed. The Allegheny and Monongahela Valleys, once the heart of Indian country in the Ohio for immigrant Delaware, Shawnee, and Mingo people, became crowded with British outposts and colonial settlements. The new heart of the Ohio Indian country became the Muskingum and Scioto River valleys. ${ }^{91}$

The Turtle and Turkey leaders on the Muskingum demanded that the British and the American colonists respect their independence and their rights to the Ohio Valley. This insistence was also a double-edged sword. Shingas wanted both a "liberating distance" from colonial settlements and at the same time, to enjoy the opportunities of commercial trade with British traders. ${ }^{92}$ Christian Post noted that Delaware leaders sought to secure a distance between the races so that the Delawares "may live by [themselves] a due distance from us ... [as a way] to secure theire hunting. . . ." Post also believed that the Delaware men would not give up their hunting territory to become farmers. He warned that they "will therefore rather die than submit to work. $" 93$

The Delawares' expectations regarding their autonomy and rights to a new homeland were dashed by the reality of a clash of cultures on the frontier. As quickly as the French departed the Ohio by 1760, new difficulties arose on the British frontier. Trade between Indians and whites flourished. But as Indians made their ways near British troops, a "volatile atmosphere" of fear, mistrust, and hatred erupted. There were drunken brawls between Indians and British soldiers and this carried past the military outpost as Indians and whites exchanged

a people by the Six Nations. Also see McConnell, "Kuskusky Towns and Early Western Pennsylvania Indian History," 30-32.

${ }^{90}$ Goddard, "Delaware" in Trigger, ed., Handbook of North American Indians, 222. William Hunter maintains that the term "Delaware Nation was not synonymous with Delaware tribe." He referred to tribe as an ethnic classification and nation as a political identification. See Hunter, "Sub Divisions of the Delawares," 35. Also see MPCP 9: 8-10: Appendix 1.

91 McConnell, A Country Between, 209.

92 Hinderaker, Elusive Empires, 144-145.

93 Post to Governor James Hamilton, March 11, 1760, in Robert S. Grumet, ed., Journey on the Forbidden Path: Chronicles of a Diplomatic Mission to the Allegheny Country, MarchSeptember, 1760 (Philadelphia: American Philosophical Society, 1999), 19. 
insults and violence. Indians stole horses from white settlements and American squatters took control of tribal hunting grounds. ${ }^{94}$

The British attempted to remedy the problems on the frontier by enacting a disastrous policy--a legislation that increased British authority and at the same time alienated the Ohio tribes. The British government authorized Commander-in-Chief Sir Jeffrey Amherst and his subordinates to enact an Indian policy that empowered the British and their "rights of conquest" attitude in the west. ${ }^{95}$ Amherst structured his new Indian policy on fiscal conservatism. He told his Indian agents that with regard to giving gifts to Indians: "I can see very little reason for bribing the Indians or buying their good behavior, since they have no enemy to molest them."96 In his policy he restricted such trade goods as muskets, powder, knives, tomahawks, razors-anything that could be used as weapons against British troops on the frontier. ${ }^{97}$ Amherst also banned the sale and trading of alcohol to Indians. With the English in sole possession of the Ohio, Amherst and Sir William Johnson adhered to "authoritive regulation." Under this policy, trade between Anglo-Americans and Indians would be restricted to British outposts on the frontier and regulated by British officers. ${ }^{98}$

John Heckewelder noted that Delawares cherished the "axes, guns, knives, hoes, shovels, pots, and kettles ... to which they have now become accustomed, and which they can no longer do without." ${ }^{99}$ By refusing them these trade items or making them harder to acquire, Amherst

94 McConnell, A Country Between, 159-161; William R. Nester, "Haughty Conquerors": Amherst and the Great Indian Uprising of 1763 (Westport, Connecticut: Praeger, 2000), 52.

${ }^{95}$ McConnell, A Country Between, 146-147.

96 Jeffrey Amherst to Sir William Johnson, Dec. 30, 1761, in Johnson Papers, 3: 597-598. Richard White in The Middle Ground, thoroughly discusses the dynamics of gift giving as a mechanism to seal alliances on the frontier. According to White the French understood the necessity of giving gifts as a way to keep peaceful relations; Amherst did not. The subject of gift giving as a component of diplomacy is discussed throughout White's study. Also see Wilbur R. Jacobs, Diplomacy and Indian Gifts: Anglo-French Rivalry along the Ohio and Northwest Frontier, 1748-1763 (Stanford, California: Stanford University Press, 1950).

${ }^{97}$ Amherst to Sir William Johnson, Dec. 30, 1761, in Johnson Papers 3: 883.

98 Johnson to Amherst, Feb. 22, 1759, in ibid., 10: 103-104, 354-355.

${ }^{99}$ Heckewelder, An Account of the Indian Nations, 191. The Fort Pitt inventory of goods to be traded to the Ohio Indians in 1761 included men's' plain and ruffled shirts, coats for men and children, "Womens Wo[r]sted Socks," colored yarn, vermilion, brass and tin kettles, silver 
dealt the Ohio Delawares and other Indian nations a severe blow. The British instigated an Indian rebellion in the west, which had a deep imprint on the development of the Delaware nation.

In opposition to the new British trade policy, western Delawares gathered together "under the guidance of charismatic prophets or respected headmen."100 Delawares in the Ohio welcomed the revitalization ideologies of Wolf spiritual leaders Neolin and Wangomen ("wellbeloved"), and the political radicalism of the Turtle chief Netawatwees. These nativist movements focused on a return to traditional values, an anti-British rhetoric, and an opposition to being dependent on the trade goods of the whites. Delaware leaders embraced the doctrine of the prophet Neolin as a way to mobilize "sufficient social and political integration" and to use native spirituality as a rallying point for unification. ${ }^{101}$ Neolin advocated that Delawares, who had already physically isolated themselves from the Anglo world, "learn to live without Trade or Connections with the White people" and support "themselves as their forefathers did.",102

The period of the 1760s was the "Indian Great Awakening;", 103 a time in which Neolin and Wangomen opposed the secular influences that whites had brought to their people. During this period, western Indians of all nations were awakened to the fact that they "shared a conflict with Anglo-America" and needed to unify as a race. The Delawares in particular, realized that they needed to "take hold of their destiny by regaining sacred power." 104

Duane Champagne maintains that the revitalization movement of Neolin "consolidated the three major Delaware political groupings into a religiously and politically unified national

brooches, large crosses, "ear Bobs" and "Large Silk handk." See "Regulations for the Trade at Fort Pitt" in Johnson Papers 2: 533-534.

100 McConnell, A Country Between, 229.

101 Champagne, "Delaware Revitalization Movement," 117.

102 James Kenny in Jane T. Merritt, "Dreaming of the Savior's Blood: Moravians and the Indian Great Awakening in Pennsylvania," The William and Mary Quarterly 54 (October 1997): 731.

103 The term "Indian Great Awakening" can be found in Gregory Evans Dowd, $\underline{\mathrm{A}}$ Spirited Resistance: The North American Indian Struggle For Unity, 1745-1815 (Baltimore: The John Hopkins University Press, 1992), 23-46.

${ }^{104}$ Hinderaker, Elusive Empires, 182. 
government." He believes that the creation of a national religion structured around the traditional Big House Ceremony brought these tribes together. ${ }^{105}$

While Champagne's point is well made, he has overestimated the role of cultural revitalization in the national development of the Delawares. Revival, on a spiritual basis, was a short-lived phenomenon. Delawares by this period were dependent upon commercial trade goods for survival. Also nativist and revivalist movements, that emphasized shunning British trade goods, could not reconcile itself with the pan-Indian rebellion of 1763, lead by the Ottawa leader Pontiac and Kiashuta of the Senecas, which was in response to Amherst's trade restrictions. This uprising, in essence, was a militant protest against being cut off from those trade commodities.

Pontiac and other influential leaders unified the western Indian nations into action. Delaware warriors, together with other western tribes such as the Shawnees, Ottawas, Chippewas, Wyandots, and western Senecas, joined Pontiac and Kiashuta and took control of ten out of the thirteen British forts they attacked. ${ }^{106}$

During Pontiac's war, the Delaware war captains came to the forefront in implementing policy among the phratries. While Tamaqua, Shingas, and William Anderson of the Turkey phratry opposed the attacks against British forts and settlements in the Ohio, they could not prevail upon Delaware war captains and their warriors to stay clear of the war trail. ${ }^{107}$ As during

${ }^{105}$ Champagne, "Delaware Revitalization Movement," 115. For more on revivalist movements as a tool of moral reform see White, The Middle Ground, 279-283; Merritt, "Dreaming of the Savior's Blood," 723-746; Anthony F.C. Wallace, "New Religions Among the Delaware Indians, 1600-1900," Southwestern Journal of Anthropology 12 (Spring 1956): 1-17.

${ }^{106}$ Much has been written about Pontiac's Rebellion, Uprising, or Conspiracy. William Nester considers this uprising to be a "war of self-determination" of western Indians in a Britishdominated North America. See Nester, Haughty Conquerors, X. Some of the best works regarding Pontiac's War includes Nester's, Naughty Conquerors; Dowd, A Spirited Resistance; Dowd, War Under Heaven, Howard Peckham, Pontiac and the Indian Uprising (New York: Russell and Russell, 1947); and of course Francis Parkman, The Conspiracy of Pontiac. The British outposts at Niagara, Pitt, Ligonier, and Detroit withstood the sieges of the western Indians. Fort Bedford, ninety miles east of Pitt, also held out against the attacks.

${ }^{107}$ A. T. Volwiler, ed., "William Trent's Journal at Fort Pitt, 1763," The Mississippi Valley Historical Review 11 (March-June 1924): 399. In June of 1763 four Shawnees met with Alexander McKee (in charge of Indians affairs at Fort Pitt) and informed him that the "Capts and Warriors of the Delaware pay no regard to their Chiefs who advised them not to accept the Hatchet. ..." Tamaqua, Shingas, and William Anderson sent messages of intelligence to Fort Pitt on the progress of Pontiac's war along the Great Lakes. They also requested that the white 
the French and Indian War, the "prowess of the Delaware warrior became known from the Atlantic seaboard to the Mississippi." ${ }^{108}$ Delaware war parties acted more "For the welfare of [their] nation," raided throughout the region, bringing "home the trophies of war," including white captives, and leaving behind the destruction of American settlements. ${ }^{109}$ The Delawares were particularly active in sieges against Fort Ligonier and Fort Pitt. ${ }^{110}$

Despite the initial success of Pontiac and his followers, the uprising fell apart when fortunes turned in favor of the British. On August 5th and 6th, 1763, Colonel Henry Bouquet decisively defeated the western tribes at the abandoned outpost of Bushy Run at Edge Hill (approximately twenty-six miles southeast of Fort Pitt). The siege of Fort Pitt was lifted on August 10. ${ }^{111}$ Not wanting another costly Indian war, the British ministry issued a Royal

inhabitants leave Fort Pitt while they had the chance. See "Intelligence brought to Fort Pitt by Mr. Colhoon," June 1, 1763, in Stevens and Kent, eds., Wilderness Chronicles, 245-246.

${ }^{108}$ Newcomb, Culture and Acculturation, 87.

${ }^{109}$ Excerpt from " The Song of the Lenape Warriors Going Against the Enemy” in Heckewelder, An Account of the Indian Nations, 210-211.

110 John W. Jordan, ed., "Journal of James Kenny, 1761-1763," The Pennsylvania Magazine of History and Biography 37 (1913): 183. In Kenny’s journal entry on Jan. 13, 1763, he noted that, in the "attacks upon [Fort] Leigonier . . . there were many Delawares."

111 Sipe, Indian Wars of Pennsylvania, 420; O'Meara, Guns at the Forks, 226. Captain Bull, the son of Teedyuscung, was a fierce opponent of settlers who entered Delaware land in the Wyoming Valley. On April 19, 1763 Teedyuscung's cabin at Wyoming was burnt to the ground, as he lay asleep, in a "drunken stupor." Connecticut settlers may have been involved in the burning of Teedyuscung's cabin. Taking advantage of the turmoil in the west and in retaliation for his father's death, Captain Bull and other Delawares of the Susquehanna, raided in the Wyoming Valley (near current-day Wilkes-Barre), in the fall of 1763. In October of 1763, Bull moved south and raided in Northampton and Cumberland counties in Pennsylvania. Bull boasted that during these raids, he alone had killed twenty-six settlers. During the spring of 1764 , Andrew Montour and a large party of Iroquois (Oneidas and Tuscaroras) were sent to punish the Susquehanna Delawares for these frontier raids, and captured Bull and twenty-nine of his warriors. Montour presented Bull to Sir William Johnson, who placed him in a New York City jail. See Johnson Papers 7: 350-351; 14: 160; Wallace, Teedyuscung, 207, 210, 214, 217, 260 265; Weslager, The Delaware Indians, 246-247. Keekyuscung, the prominent Turkey war captain, was killed at Bushy Run. See footnote 12 in Stevens and Kent, eds., Wilderness Chronicles, 134. 
Proclamation in October that limited white settlement west at the crest of the Appalachian Mountains until a formal western expansion policy could be established. ${ }^{112}$

Future events, however, had deeper relevance in the process of Delaware nationhood than did short-lived revival movements. In October of 1764 Colonel Bouquet, with 1500 Royal American troops and auxiliary forces of Virginia militia and the Black Watch, moved into the Muskingum to chastise the Delawares for their part in Pontiac's Rebellion and to procure the release of English captives. Bouquet met with Indian leaders at Fort Pitt. An Onondaga and an Oneida told him that the Delawares and Shawnees were in a "state of confusion." They asked Bouquet to approach the Muskingum with caution and civility and they informed Bouquet that the Delawares, in particular, were very remorseful "for what they have done, and are collecting all their prisoners from the lower Shawanese town in order to deliver them up at Sandusky."113 Bouquet was unimpressed and told the Iroquois that the Delawares and Shawnees were a "false people" who deceived them. ${ }^{114} \mathrm{He}$ did agree to meet with Delaware leaders at Tuscarawas. To insure that Delawares would not violate the truce, Bouquet detained the war captains Captain Pipe and Captain Johnny. Bouquet threatened to put them to death if the Delawares renewed hostilities against his troops. ${ }^{115}$ He remarked that Pipe and Johnny were to remain at Fort Pitt "as a security, that you shall commit no further hostilities." 116

For the first time in documented history, there is reference to the three animal tribes acting together with shared aims as representatives of the Delaware nation. Tamaqua, the leader of all western Delawares, greeted Bouquet on "behalf of the Chiefs, Warriors, Women, and Children of our three Tribes. ..." 117 In Bouquet's journal he acknowledged each animal

112 McConnell, A Country Between, 234, 248; Jennings, Empire of Fortune, 461-463. The Royal Proclamation line as a demarcation between whites and Indians was first discussed at Easton in 1758. The British could not stop settlement west of this imaginary line.

${ }^{113}$ Iroquois Indians to Bouquet at Fort Pitt, Oct. 2, 1764, in Rupp, ed., Early History of Western Pennsylvania, 146.

${ }^{114}$ Bouquet to Iroquois at Fort Pitt, Oct. 3, 1764, in ibid., 147.

115 Ibid., 148.

116 (Author unknown) Referred to as a "Lover of his Country" in "An Historical Account of the Expedition Against the Ohio Indians in the Year 1764, under the Command of Henry Bouquet, Esq" (Dublin: John Milliken, 1769) 27. Bouquet detained the two Delaware war captains after a British soldier was murdered on the Muskingum.

117 Tamaqua to Bouquet, Nov. 10, 1764, in Johnson Papers 2: 457. 
division and their principal leaders, not to divide them, but to acknowledge them as vital parts of the nation. Both Bouquet and the Delaware leaders understood that peace could not be reached unless all three tribes acted in concert as a nation. Bouquet first met with Custaloga of the Wolf tribe and Kiashuta of the Chenussio Senecas, and secured the release of eighteen prisoners. He then met with Tamaqua who agreed to release over eighty captives held by the Turkey tribe. ${ }^{118}$ Netawatwees feared to meet with Bouquet. His tribe of Delawares was responsible for the murder of schoolmaster Enoch Brown, other teachers, and eleven school children at a schoolhouse in Cumberland County, Pennsylvania. ${ }^{119}$ Bouquet became "dissatisfied with the conduct" of Netawatwees when he failed to show at the talks and "deposed him." Bouquet met with a council member named Tapiscawen and appointed him chief leader of the Turtles. ${ }^{120}$ Throughout most of the talks, Bouquet directly addressed the chiefs and councilors of all three groups as one nation. ${ }^{121}$

Tamaqua confided to Bouquet his hopes that the "three Tribes" of Delawares would be able to "embrace Peace once more with their Brethren" and to "now think of nothing but hunting, to exchange their Skins and Furs with their brethren for Cloathing." ${ }^{122}$ Bouquet had the

${ }^{118}$ William Smith, Nov. 11, 1764, on the Muskingum in Booth, ed., Tuscarawas Valley in Indian Days, 69-77; "An Historical Account of the Expedition," 16-17.

${ }^{119}$ Ibid., 212. Bouquet was furious with Netawatwees and his band. The chief had no hand in the slaughter, but could not control his warriors. The war party that massacred Brown and his students, took a boy captive. They killed the boy on the trail near Little Beaver Creek. Bouquet condemned them for they had the "impudence to fix his head upon a pole in the middle of the path as a taunt to those who pursued." See Rupp, ed., Early History of Western Pennsylvania, 151.

${ }^{120}$ Ibid., 73; MPCP 9: 226-229. The meetings on Nov. 1, 9, involved the Wolf Delawares and western Senecas, exclusively. Bouquet understood the close geographical and historical relationship between the two. Also see Weslager, The Delaware Indians, 248-249. At this time, Bouquet refused to acknowledge the authority of Netawatwees, who retained his position later that year and remained leader of the Turtle tribe and chief councilor of all Delawares until his death in 1776.

${ }^{121}$ Bouquet in Johnson Papers 2: 458-461

${ }^{122}$ Tamaqua to Bouquet, Nov. 10, 1764, in Johnson Papers 2: 456-457; MPCP 9: 226. Shingas, recognized as the head leader, died during the winter of 1763. Keekyuscung told the Quaker trader James Kenny in 1763 that Tamaqua was not king of the Ohio Delawares. He told Kenny that it was the "people of Virginia," and not the Delawares who made Tamaqua a king. Keekyuscung contended that Netawatwees of the Turtle tribe was the Delaware king. See Jordan, 
Ohio Indians cease hostilities in all of Indian country and forced them to give up over 200 English captives. The Indians also agreed to send deputies to Johnson Hall in New York to meet with William Johnson and to officially "conclude with him a final and lasting Peace." 123 Delawares exchanged prisoners for trade goods, desperately needed by a people approaching starvation. $^{124}$

The following May, both Ohio and Susquehanna Delawares mutually agreed to meet with Sir William Johnson, who also met with Shawnee and Mingo leaders at Johnson Hall during these talks. Principal leaders among the Susquehannas were Long Coat (Anindamooky) and The Squashcutter (Yaghkapose). Captain Kill Buck of the Wolf tribe attended the talks as a representive of the Ohio Delawares, as a "Deputy from our Chiefs . . . on behalf of all our Nation." Killbuck, accompanied by Turtles Heart, carried the words of the phratry heads, Tamaqua and Custaloga, and the Turtle councilor named Teatapercaum. At the talks, Susquehanna and Ohio Delawares separately agreed to twelve specific articles of peace. The first of this agreement was that both eastern and western Delawares would release all English captives, "Deserters, Frenchmen \& Negroes." He demanded that they "promise and engage never to take revenge for any act committed by Individuals of the British Nation" but to take their grievances to the commander of the military post. Johnson also asked the Delawares to use their influence on Shawnees, who were still fighting against the British. ${ }^{125}$

Johnson promised that settlement would be limited and only achieved through the consensus of the Iroquois. (The Delawares had to abide by the decisions of the Six Nations regarding white settlement in the Ohio). He also guaranteed the Delawares a restoration of English trade in the Ohio, and that they would "be once more received into the Covenant Chain

ed., "Journal of James Kenny," 157. Keekyuscung also told Kenny that the principal Wolf leader Custaloga was one half Seneca.

${ }^{123}$ A proclamation by Pennsylvania Governor John Penn, Dec. 5, 1764, in MPCP 9: 234.

${ }^{124}$ Regarding the conditions of some of the Delaware bands, Sarah Carter a white captive mentioned that the Chenussio Seneca had "Corn Enough," but the Delawares [Munsees] were "starving, having Dug up sev.[eral] English dead bodys \& Eat them" in Johnson Papers 4: 497.

125 "Treaty of Peace concluded with the Delawares" at Johnson Hall, May 8, 1765, in NYCD 7:738; MPCP 9: 277-280. The British knew Teatapercaum as Samuel. 
of Friendship with the English." 126 The Delaware leaders signed a treaty with the British admitting responsibility for their role in Pontiac's uprising. Johnson remarked that the three Delaware divisions, locked in consensus, agreed to the peace proposal. Delawares consented that they would no longer molest the King's subjects and would turn over all disputes with whites to royal authority. ${ }^{127}$ Johnson acknowledged the influence and authority of the Delaware deputies such as Captain Kill Buck in confirming a treaty for the "rest of their whole Nation." ${ }^{128}$ Most importantly, these talks clearly show that the British had finally realized that western groups of Delawares had no intention of ever returning to the Susquehanna. They refused to be shackled to past reciprocities of subservience and had forged a new individuality as an emerging nation in the Ohio.

Michael McConnell contends that these Delaware groups "reconstituted in the west" and through a "process of social and political coalescence," they allied themselves in an ethnic sense. While McConnell is correct in his overall assessment, he fails to address the complexities of this procedure. A key factor in the independence and unification of the western Delaware tribes was their complete separation from the eastern Delawares. With this parting, western Delawares were free to organize the type of strong national political structure that had never existed among the dispersed bands in the east. The "coalescence" that McConnell mentions was not a distinct moment to be pinpointed by future historians. In fact, the initial "coalescence" centered first on the strong interaction between the Turtle and Turkey phratries. The Unami-speaking Turtle and Turkey tribes, united by ethnicity and language, banded together first in the Allegheny and

126 "Treaty of Peace concluded with the Delawares" at Johnson Hall, May 8, 1765, in NYCD 7:738; MPCP 9: 277-280.

${ }^{127}$ Sir William Johnson to Cadwallader Colden in Johnson Papers 3: 746; MPCP 9: 280. George Croghan's observations differ from Johnson regarding Delaware political solidarity. Croghan contended that the Turtle and Turkey leaders "were very averse to making peace with the English" until Captain Kill Buck returned from Johnson Hall. In fact, they expressed contempt for Custaloga of the Wolf tribe. They considered him to be "an old Woman" for quickly agreeing to peace with Bouquet. See "Croghan's Report," 1765 in Clarence Walworth Alvord and Clarence Edwin, eds., Collections of the Illinois State Historical Library, vol. 11, The New Regime, 1765-1767 (Springfield: Illinois State Historical Library, 1916), 5-7. Despite the differences between Johnson and Croghan regarding Delaware consensus, the ethno-historian Melburn D. Thurman contends that by 1765 , there was a clear indication that "war and peace making powers [for the nation] resided with each of the three Delaware tribes." See Thurman, "Delaware Indians in Ethnohistory," 113-114.

${ }^{128}$ Sir William Johnson at Johnson Hall, July 13, 1765, in NYCD 7: 754. 
Beaver valleys of western Pennsylvania, then in new towns across the Ohio River along the Muskingum. ${ }^{129}$ With regard to the Wolf phratry, the Delawares told John Heckewelder that the more militant "Monseys, had [traditionally] chosen to live back of the other two tribes," as a "bulwark for their protection." 130 Geographically distanced, the Wolf tribe had to be slowly integrated into the Delaware nation. Their participation in the Bouquet peace talks was but a start.

Even more so than the social and ethnic commonalities, it was the strong presence of the phratry leaders that affected the once-autonomous animal tribes to move toward a needed centralized structure. Shingas, Pisquetomen,Tamaqua, Netawatwees, and Custaloga, among other headmen, established a solid base for their respective tribes while at the same time planting the seeds of political nationalization. Beneath the veneer, in the aftermath of the Muskingum talks with Colonel Bouquet, the Delawares were taking the national form of a "three divisional confederacy.", 131

The experiences of the Seven Years' War and Pontiac's Rebellion had established the Ohio Delawares as a separate entity from the Susquehanna Delawares. By severing themselves from their ties in the east, Ohio Delawares were in place to be more receptive to radical changes in organization. This period galvanized once autonomous bands of Delawares into a more cohesive polity. In the aftermath of 1765 , Delawares had a greater conception of a common cause--the survival and security of their homelands on the Muskingum. The political unity of the Delaware tribes was not complete and would go through more transformations as the turbulence of the American Revolution approached the Ohio.

129 Ibid., 225.

${ }^{130}$ Heckewelder, An Account of the Indian Nations, 52-53. Lenape oral traditions have established much of this relationship among the three Delaware phratries. According to Heckewelder, the Turkey tribe was more stationary than the "rambler" Wolf tribe and always clung close to the Turtles. This attachment may have much to do with a common Unami dialect between the two Delaware tribes. Thurman has mentioned that there has always been a misconception that the Wolf tribe, because of geographical isolation, was never a full-fledged member of the Delaware nation. Thurman maintains that "spatial segregation" was not indicative of "political segregation." See Heckewelder, An Account of the Indian Nations, 253-254; Thurman, "Delaware Indians in Ethnohistory," 107-108.

${ }^{131}$ Champagne, "Delaware Revitalization Movement," 115. 


\section{Chapter IV}

\section{White Eyes, The Great Council, and the United Brethren: Peacemakers on the Muskingum, 1770-1776}

In Lenape folk tradition there was the tale of Nanapush who was the spirit helper of the Creator, known as Kishelamakank. Nanapush gave the Lenape a new Earth in which to reside, created their culture, and gave birth to the animals that offered sustenance. Lenape oral history also maintains that Nanapush fought his father, known as Wunch 'enekis, to avenge the death of his mother who was killed by the father. The father denied that he had murdered his mother, but seeing his son's determination for vengeance, agreed to fight him. Locked in a ferocious fight with bow and arrows, knives, and bare hands, the father told his son to cease the battle. "Enough my son, enough . . . to go on is senseless. Let us have peace between us."1 The father taught his son the art of diplomacy. With the use of the pipe of peace, the father and son smoked together and "brought their hearts and minds together as one, resolving the differences between them." The Delawares were instructed that an integral part of national greatness was to be militarily strong, but without striving for "power and control over others." Through the art of diplomacy, Lenapes hoped to gain the ideals of "peace and order" in their world. ${ }^{3}$

To insure the success of Lenape diplomacy with other nations and among themselves, Nanapush also brought four sacred gifts: The Fire of Peace, the Pipe, the Sacred Tobacco, and Sweetgrass, to enhance the strength and wisdom of the Lenapes when they were in council. Nanapush told Lenapes: "As the smoke from the pipe rises to the sky, your thoughts and prayers will be heard by the Creator. Peace and order, and good thinking will be restored among the people." 4

${ }^{1}$ Hi takonanulaxk (Tree Beard), Grandfathers Speak, 55. According to Lenape and most northeastern woodland Indian oral traditions, the Earth was formed on the back of The Great Turtle, known to the Lenapes as Taxkwax. The Lenapes refer to the Earth as Taxkwax Mena' te (Turtle Island).

\footnotetext{
2 Ibid., 55.

3 Ibid., 55 .

${ }^{4}$ Ibid., 58.
} 
In the aftermath of Pontiac's uprising, Ohio Delaware tribes tired of war, sought peace and pressed for unity in the tradition of Nanapush, and moved deeper into the Ohio country. Throughout the decade before the American Revolution, the three phratries of Delawares secured a short-lived and very fragile national solidarity. Other key catalysts in this solidarity were the presence of a more definitive national council and the appearance of Moravian mission towns along the Muskingum River. Together with the council and Christian missionaries, a persuasive leader known as White Eyes rose as a singular voice to influence the shape of the Delaware political nation.

It was during this time that the "Lupwaaeenoawuk" (the Great Council or "Wise Men") entered the historical record. ${ }^{5}$ While each phratry had a council headed by a principal civil chief and a war captain, during the 1760 s the Great Council of the three tribes became the definitive expression of a political nation. ${ }^{6}$ Previously there was little mention or understanding of a functioning Delaware national council until their move into the Muskingum River valley. The organization of a national council fulfilled the "shared needs" of the three phratries to strike a meaningful union in a new western homeland. The Great Council served as a testament that Delawares were willing to enter into a structured union for the first time in their history.

By the 1760s, the three phratries became highly recognizable and visible in the "process of treaty making" for the Delaware nation. ${ }^{7}$ Teedyuscung made reference in 1760 to the Lupwaaeenoawuk as "the great Council over the River Ohio"--the high authority for western Delawares. ${ }^{8}$ By 1761, there was a growing awareness of a national council among the three tribes when Delaware George told James Kenny that "their Nation [was] subject to three heads . . which all had to be consulted" before any action be taken. ${ }^{9}$ In July of 1762 , Netawatwees,

${ }^{5}$ The term Lupwaaeenoawuk, can be found in Weslager, The Delaware Indians, 194, 288290. The men who held council were referred to as Wemiehatschimolsitschik ("All those who continually hold council"). Correspondance with Raymond Whritenour, August 18, 2002.

6 Thurman, "Delaware Indians in Ethnohistory," 120-121.

7 Hunter, "Sub Divisions of the Delawares," 35.

8 Teedyuscung to Pennsylvania officials in Philadelphia, March 29, 1760, in Grumet, ed., Journey on the Forbidden Path, 20-22.

${ }^{9}$ Delaware George to James Kenny, August 14, 1761, in Jordan, ed., "Journal of James Kenny," 18. 
Tamaqua, and Custaloga, held "Several Councils amongst" themselves regarding the release of white settlers, who were captured during the Seven Years' War. ${ }^{10}$

This council, which housed the civil chiefs and war captains of the Turtle, Turkey, and Wolf tribes, became more recognizable after the peace talks with Colonel Bouquet on the Muskingum in November of 1764. During the various meetings with Bouquet, Tamaqua and Custaloga had central roles in mediating a peace for all Western Delawares. Despite the temporarily weakened diplomatic status of the Turtle group, a national Delaware council was slowly establishing a presence on the Muskingum. After Bouquet's military left the region, a western Delaware council led by the phratry leaders Netawatwees (restored as chief), Tamaqua, and Custaloga, met as a national council, to discuss tribal concerns regarding a settlement with the British. ${ }^{11}$ A better understanding of the structure and mechanism of the council was furthered through the careful observations of the Moravians, Zeisberger and Heckewelder. They became critical witnesses to the development, unification, and eventual fragmentation of the Delaware nation.

The Lupwaaeenoawuk contributed as an integral part of Delaware political organization in this post-Seven Years' War period. At that time, George Croghan noted that many of the Delaware towns were in "great Confusion amongst themselves and without any order in their Council." ${ }^{12}$ Croghan based this assessment of chaos among the Delawares as a result of the news that two unnamed Delaware war captains, "differed in Council \& stabbed each other ..." 13 This, however, was an isolated incident and not indicative of council behavior at that time. Many witnesses to the procedures of the council were impressed with the order and respect for protocol demonstrated in the Great Council House of the Delaware nation. Nicholas Cresswell, a young English adventurer, maintained that the Great Council House had been constructed at Gekelemukpechunk, later known as Newcomerstown ("the water that is always still"), the capital Delaware town on the Muskingum, solely for the discussion of national affairs. There the Delawares kept the central council fire. During the council meeting, every item was discussed

\footnotetext{
10 James Kenny, July 8, 1762, in ibid., 161.

11 Champagne, "Delaware Revitalization Movement," 114-115.

12 George Croghan, March 1765, "Journal of transactions with the Indians at Fort Pitt," in MPCP 9: 254-256.

${ }^{13}$ Croghan, March 1765, in ibid., 9: 255.
} 
with the "greatest regularity and decorum, silence and deliberation." ${ }^{14}$ John Heckewelder observed that Delawares, like most American Indian nations, had a great respect for council etiquette. Only one person spoke at a time and the others listened attentively until the speaker had concluded. The tone of the speaker's voice might become more intense if he was directing his agenda towards a group of warriors. ${ }^{15}$

Phratry leaders, meeting under the structure of the Great Council, pursued both unity and peace as a national agenda. This national goal became manifested through the influences of the United Brethren on Delaware leaders and through the peacemaking efforts of the prominent Turtle leader, White Eyes. The Lupwaaeenoawuk and the presence of Moravian missionaries served the higher visions of White Eyes in his quest for a united and stable Delaware Indian nation.

To survive as a people, the Delawares had to augment the ideals of peacemaking with the reality that an Indian nation with a strong warrior presence could deter the unwanted territorial expansion of British America. They could seek peace with the Anglo-Americans, because the historical examples of their raids into central Pennsylvania in 1755 would always serve as a reminder that the Delawares, even at band level, were not "weakling women" and could exact great damage on any people who might do them injustice.

However, this was a time in which peace, through diplomacy, was preferred by the leaders, who became tired of the ravages of war. West of the Ohio River in the Muskingum River valley, the Delawares established a series of small villages and "satellites of larger towns." Diplomatic centers such as Gekelemukpechunk and Goschachgunk, also known as Coschocton, became the chief residencies for powerful and influential civil and war leaders, all seeking consensus in determining what was best for the Delaware people. ${ }^{16}$

14 Nicholas Cresswell, The Journal of Nicholas Cresswell, 1774-1777 (New York: The Dial Press, 1924), 113. Newcomerstown was named in honor of the residing Turtle chief Netawatwees (Newcomer).

15 Heckewelder, An Account of the Indian Nations, 107-112, 189-190. For details on Delaware council meetings, see Zeisberger in Hulbert and Schwarze, eds., "Zeisberger's History," 94-99.

16 McConnell, A Country Between, 229. Gekelemukpechunk (Newcomerstown) was the first Delaware capital in the west. In 1776, the Delawares moved their capital to Coschocton, known by the Delawares as Goschachgunk, located at the forks of the Tuscarawas and Walhonding. Goschachgunk, a settlement composed of log houses and a large council house was a 
Phratry consensus became increasingly important to the stability of the Delawares after the 1760s. The three phratries worked together in the context of the Great Council. Leaders were closely scrutinized and chosen by "consent of the tribe and whole nation." A chief, even though recognized as a figure of authority, was dependent on the advice of his counselors. ${ }^{17}$ This careful procedure of selection, and the vital role of the counselors, insured the Delaware nation that men of good character would lead the people through consensus-- not in an autocratic fashion. The layers of consensus needed for governmental decisions, interlocked phratry and national concerns. David McClure, a visiting Presbyterian missionary, witnessed firsthand a Delaware Great Council meeting and the concern shown for consensus. Netawatwees and the council

in number about 12, sat on Buffalo skins. Civil chiefs sat on one side of the entrance of the council house, chief warriors sat on the other side-- Young men \& women $\&$ children occupied the rest of the house. Warriors were painted, \& their heads \& necks ornamented with feathers \& strings of wampum. ${ }^{18}$

McClure noted that the speaker worked the council house to gain a consensus. He contended: listeners gave "shouts of applause to what they dislike, as uttered by the speaker, as freely as they do what they approve."19 Thus council members strove for agreement in national affairs. This became the political ideal among the leaders of this fledgling Indian nation.

Political consensus removed the stigma of inaction and decentralization that had previously encumbered national development. Agendas could now be pursued on a national level. In April of 1770, the Delaware Great Council met at Gekelemukpechunk. They invited the United Brethren or Moravian missionaries to move their missions of Delaware Christians from the Susquehanna to minister to those Delawares who remained at the Kuskuskies and in the

chief Unami town. For an extensive list of Delaware towns in the west see Swanton, Indian Tribes of North America, 48-55.

17 Zeisberger in Hulbert and Schwarze, eds., Zeisberger's History," 112-113. On the dependency of the chiefs on the council see Wainwright, George Croghan, 17, 40-46.

18 Entry of David McClure, Sept. 22, 1772 in David McClure, with notes by Franklin B. Dexter, Diary of David McClure: Doctor of Divinity, 1748-1820 (New York: The Knickerbocker Press, 1899), 46-47.

19 Ibid., 47-48. 
Muskingum towns farther west. "Epidemical disease" had raged through the Delaware towns in Ohio country and carried "off great numbers" of the population. Custaloga, the Wolf leader, became convinced that witchcraft had caused the epidemic, and that "by embracing Christianity the contagion would cease." He also feared that this catastrophe could destroy national unity. ${ }^{20}$ Delawares were not rejecting their own religion but rather adding Moravian religious doctrine to their beliefs. They believed Christianity might serve as a spiritual weapon to combat the biological epidemics that swept through the Delaware communities by "augmenting their own collective powers against dangerous forces." 21 Christianity served as a "remedy" to the problem. $^{22}$

Leaders such as Custaloga and White Eyes saw the influence of the Moravians as a stabilizer rather than a threat to the Delaware nation. Whether it was the nativist proselytizing of Neolin or the Christian doctrine of the Moravians, Delaware leaders assessed the value of cultural and spiritual rejuvenation through moral reform as a mechanism to insure a cohesive political nation. Throughout the eighteenth century, Moravian missionaries and nativist leaders contended with each other for the collective soul of the Delaware people. In 1740, after failing to establish a successful Christian mission in Georgia among the Cherokees, David Zeisberger, his wife, son, and fifteen of his Moravian helpers moved to Pennsylvania and founded Bethlehem, in the Nazareth Valley at the forks of the Delaware River. Among Zeisberger's neighbors were immigrant New Jersey Delawares. This praying town eventually became the center of the Moravian Church in America. ${ }^{23}$

In Pennsylvania, the Moravians quickly established themselves among the eastern Delawares. By the late 1740s there were mission towns in Gnadenhutten (twenty-five miles

20 John Heckewelder in Wallace, ed., Travels of Heckewelder, 95; Heckewelder, Narrative of the Mission, ed., Connelley, 226-228.

${ }^{21}$ McConnell, A Country Between, 229.

${ }^{22}$ Heckewelder, Narrative of the Mission, ed., Connelley, 113. For a more extensive view of the dynamics between missionaries and American Indians during the colonial era see Axtell, The Invasion Within.

${ }^{23}$ Elma E. Gray and Leslie Robb Gray, Wilderness Christians: The Moravian Mission to the Delaware Indians (Ithaca, New York: Cornell University Press, 1956), 24-25; Earl P. Olmstead, Blackcoats Among the Delaware: David Zeisberger on the Ohio Frontier (Kent, Ohio: The Kent State University Press, 1991), 4-6. 
north of Bethlehem) and Shamokin, on the Susquehanna. ${ }^{24}$ In 1765 Zeisberger founded Friedenshutten on the Susquehanna near the Indian town of Wyalusing in current-day Bradford County and in 1768, Zeisberger and his followers crossed the Alleghenies to the headwaters of the Allegheny River to establish Goschgoschunk among the Munsees, near Tionesta in northwestern Pennsylvania. ${ }^{25}$ At that time, Moravian Delawares had remained with the majority of Munsees in Allegheny country. There, Zeisberger and Christian Delawares lived at the mission towns of the Allegheny Valley. Later he founded Friedenstadt, south of present-day New Castle, Pennsylvania. ${ }^{26}$ These missions were situated in the shadow of the trading towns of the Kuskuskies, whose primary commodity was liquor. ${ }^{27}$ The sale of alcohol alarmed Zeisberger because his missions were constantly harassed and vandalized by those he considered bellicose "drink-crazed heathens" of the Munsee-Wolf and Seneca tribes. ${ }^{28}$ John Heckewelder, assistant to Zeisberger, condemned the actions of those he called the "drunken Munsee chauvinists" who resided in these "degenerate, rum-soaked" trading towns. 29

24 Gray, Wilderness Christians, 24-26; Olmstead, Blackcoats Among the Delaware, 3-6; Wallace, ed., Travels of Heckewelder, 1-5. The Unity of the Brethren (Unitas Fratrum) was the oldest international Protestant church in the world. The Moravian religion originated in 1457 in the German provinces of Bohemia and Moravia. John Huss, its originator, led a Protestant Reformation a century before Martin Luther. Moravian missionaries entered North America in 1735, as missionaries to the Creek and Cherokee Indians in Georgia. When their efforts failed among these people, the missionaries relocated into the Nazareth and Lehigh valleys of eastern Pennsylvania to minister to the Delawares. Zeisberger and his fellow missionaries branched out into New York to minister to Hendrick and his Mohawks. Among the Mohawks as missionaries in 1745, Zeisberger (1721-1808) and Christian Frederick Post were accused of being French spies and jailed by New York authorities for fifty-one days.

25 Gray, Wilderness Christians, 408-409; Olmstead, Blackcoats Among the Delaware, 67. Goschgoschunk was also referred to as Goschgoschink.

26 Olmstead, Blackcoats Among the Delaware, 6-7.

27 McConnell, "Kuskusky Towns," 36-37.

28 Zeisberger in Gray, Wilderness Christians, 47.

29 Heckewelder, March 1773, in Wallace, ed., Travels of Heckewelder, 104. The Reverend John Gottlieb Heckewelder (1743-1823) was born in Bedford, England. He immigrated to America in 1754 and settled in Bethlehem, Pennsylvania to study at the Moravian children's seminary. During the Seven Years' War, Heckewelder accompanied the Moravian missionary and frontiersman Christian Frederick Post (1710-1785) on a diplomatic mission to meet with the Ohio Indians and persuade them to terminate their alliance with the French. Heckewelder spoke fluent German and the Unami dialect of the Delaware language. In 1762, he moved to the 
At the invitation of Delaware chiefs, Moravians entered the Ohio Valley to establish a community of Delaware Indian praying towns. These mission towns served dual purposes. The intent of the Moravians was to use these missions to assimilate Christian Delawares into white society. Delaware leaders used the Moravians not only to help ward off disease by rejecting witchcraft but also to unify their people as they moved beyond the Alleghenies into the Ohio. A symbiotic relationship evolved between Delaware civil leaders and Moravian missionaries, which reflected their mutual goals of maintaining order, stability, and peace within Delaware society.

Many Delaware civil leaders supported the efforts of the missionaries to solidify the Delaware social environment in the Ohio Valley. These same headmen, seeing that their people were outnumbered by the whites and were dependent upon trade goods, embraced certain Moravian doctrines of order, progress, and neutrality. This would guarantee the flow of goods and thus secure the economic and, in the long run, the political survival of the developing Delaware nation. To exist in this new region, the Delawares had to accept the realities of a changing world and to blend Anglo conceptions of progress with traditional values. The Moravians offered a structural base for a new Delaware society in the Ohio Valley. The Delaware leaders hoped that this base could be more receptive to the preservation of peace. They pursued peace as a national policy.

Throughout the eighteenth century, American society was undergoing "cumulative and irreversible" transformations. European immigrants from the Continent, indentured servants, and African slaves entered an Anglo-dominated America and "undermined the stability of their institutional order."30 This also held true for Delaware society, as it was undergoing social change. Delaware leaders saw the strain placed upon their people by territorial relocation, trade dependency, and hatred of Indians that existed on the American frontier. Delaware chiefs believed that Moravian mission towns could serve as models for their people to emulate. Delaware chiefs openly declared that the missionaries "should not only be tolerated" by non-Christians, but

Muskingum to reside with the Delawares and start his mission work. For a brief history of the Moravian Church in Europe and America see Wallace, ed., Travels of Heckewelder, 1-31.

30 James A. Henretta and Gregory H. Nobles, Evolution and Revolution: American Society, 1600-1820 (Lexington, Massachusetts: D.C. Heath and Company, 1987), 2. 
should be given the "liberty to preach the gospel wherever they pleased." 31 Custaloga also declared that the Moravian preachers be adopted as full-fledged Delawares. ${ }^{32}$

For the most part, the Moravians were better received than other denominations. The Presbyterian missionaries David McClure and David Jones had failed in their attempts to preach to the Delawares in this region. Delawares associated Presbyterians with the border violence and "territorial ambitions" of the Scots-Irish. They could differentiate between the "doctrine and sectarian politics" of Moravians, Quakers, Jesuits, and Presbyterians. ${ }^{33}$

Zeisberger also had his ordeals ministering to native peoples. In 1768, while in the Allegheny country, he locked horns with the Munsee revivalist preacher Wangomen over their differing perceptions of spirituality. The Munsee-Wolf traditionalists did not take well to his religious teachings, which directly challenged elements of their social structures, namely warfare and purging ceremonies. Zeisberger criticized what he believed were Munsee ritual excesses and "superstitions." 34 In the midst of the consolidation of the three Delaware tribes into a nation, there was a showdown between traditionalists and Moravian supporters. Both sought to stabilize the nation as it rooted itself in a new homeland. Both had their own visions on how to

${ }^{31}$ Heckewelder in Hulbert and Schwarze, eds., "Zeisberger's History," 113.

${ }^{32}$ Heckewelder's observations of Custaloga in Heckewelder, Narrative of the Mission, ed., Connelley, 113.

33 McConnell, A Country Between, 231.

34 Zeisberger in Gray, Wilderness Christians, 44-45; Earl P. Olmstead, David Zeisberger: A Life Among the Indians, (Kent, Ohio: The Kent State University, 1997), 150-151. Zeisberger and his fellow missionaries were repelled by the traditional ceremonies of the Munsees, particularly the purging ceremony. After a successful fall hunt, the Munsees held four feasts as a way to give thanks for their good fortunes and to secure favorable vicissitudes in the future. There were banquets, feasts, dancing and singing. Men entered sweat baths and used them as a method to induce visions and hallucinations. Participants wore deerskins and wore the head of a deer as a headdress. After the sweat baths, these men then gorged themselves on bear meat, and drank hot bear grease until they vomited. This ceremony was then corrupted by syncretic influences of the trading towns. There was a week of rum drinking, brawling, and occasional murders. Heckewelder condemned purging ceremonies. To him, these rituals represented a heathen, not Christian, atonement for sins. During the revivalist period, Delaware preachers encouraged young men to purge themselves and advocated their training as warriors. Among the Shawnees, the town of Wakatomika on the west side of the Muskingum, near present-day Dresden, Ohio, became a place of martial training and purging. British traders referred to Wakatomika as "Vomit Town." Moravians also opposed purging, for they believed that Indians were ruining their health. Heckewelder, Narrative of the Mission, ed., Connelley, 104-105. See Zeisberger's comment in Booth, ed., Tuscarawas Valley in Indian Days, 98-99. 
bring stability and unity. The Moravians, supported by the Delaware peace chiefs, won the contest for the soul of the Delaware nation--for the time being. Zeisberger increased his following when he converted the feared Wolf war captain Glikhikan ("foremost sight on a gun barrel") to Christianity. Glikhikan, who was also the brother of Wangomen, believed that the "brethren have the right doctrine and preach the right way to happiness." ${ }^{35}$ Glikhikan's conversion made Wangomen less suspicious of Zeisberger and the Moravians.

The "Three Chiefs in the west," Netawatwees, Tamaqua, and Custaloga, for the most part, tolerated the Moravians and allowed for the missionaries' attempts to bring peace and unity to the Delawares. ${ }^{36}$ On May 3, 1772, Zeisberger arrived on the Muskingum with eleven Moravian Delawares, several Indian helpers, and a small group of native children. ${ }^{37}$ As the group traveled the Muskingum, Heckewelder noted that the Delawares "showed themselves friendly towards us." At Newcomerstown "they greeted us with their usual shouts of joy." Even at the Shawnee town of Wakatomika in near present-day Dresden, Ohio, the war-like Shawnees "moved about among [the converts] and showed friendly feelings" for the Christians. ${ }^{38}$

At the Delaware capital of Newcomerstown, Zeisberger met with the Turtle leader, Netawatwees and the Great Council. The council members now recognized Netawatwees, once "deposed" by Colonel Bouquet, as the head chief of the western Delawares. The Lupwaaeenoawuk "allotted [Zeisberger] . . . the Land on both Sides [of the] Muskingum River from Tuskerawy till within 3 miles of Newcomers Town. ${ }^{39}$ With his grant of land, Zeisberger eventually established the mission towns of Schoenbrunn and Gnadenhutten in 1772, Lichtenau

35 Entry of Zeisberger, June 7, 1769, in Tilde Marx, trans., "Diaries of the Moravian Missions in Western Pennsylvania, 1769-1772," transcripts in Merle Deardorff Papers, Warren Historical Society, Warren, Pennsylvania, 35; Olmstead, David Zeisberger, 160-161.

${ }^{36}$ Entry of Zeisberger, June 14, 1769, in Marx, trans., "Diaries of the Moravian Missions in Western Pennsylvania," 35.

${ }^{37}$ Olmstead, Blackcoats Among the Delaware, 7.

38 Heckewelder in August C. Mahr ed., and trans., "A Canoe Journey from the Big Beaver to the Tuscarawas in 1771: A Travel Diary of John Heckewelder," Ohio State Archaeological and Historical Quarterly 61 (1952): 297. Also see Weslager, The Delaware Indians, 288.

${ }^{39}$ Heckewelder in Wallace, ed., Travels of Heckewelder, 98. Also see C. A. Weslager, The Delaware Indian Westward Migration (Wallingford, Pennsylvania: The Middle Atlantic Press, 1978), 27. Bouquet removed Netawatwees as principal leader of the Turtle phratry in 
in 1776 , New Schoenbrunn in 1779 , and Salem in $1780 .^{40}$ When Zeisberger's people settled on the Muskingum, the non-Christian Delawares were both astonished and alarmed to see the differences in "manners and customs" of the converted Delawares from that of their own traditional culture. Some of the Delaware Christian men wore the same black suits and shoes that were required dress for the missionaries. Many western Delawares, long removed from Moravian influence in eastern Pennsylvania, were also exposed to a "doctrine preached, of which they never before" had heard. ${ }^{41}$ The Moravian missions were the first Protestant missions west of the Ohio River. $^{42}$

Delaware civil leaders accepted the Moravians into their community as a way to bolster both their own local authority and prestige within the council. They were also willing to experiment with the adoption of certain Moravian values. ${ }^{43}$ White Eyes saw the peaceful Christian Delawares as an influential factor in solidifying the coming together of the three Delaware phratries. ${ }^{44}$ Delaware leaders hoped to interweave Christian order throughout the Delaware nation on the Muskingum. Netawatwees, at the urging of White Eyes, recognized the

1765. The Delaware council quickly reinstated him once Bouquet and his military left the Ohio. With Tamaqua's death in 1769, Netawatwees became "King" of the western Delawares.

${ }^{40}$ Olmstead, Blackcoats Among the Delaware, 241-242. Mahican converts also accompanied the Lenape and Moravian missionaries. These Mahicans did not get along with the Delawares. There was constant tension and divisiveness between the Unami-Munsee speakers and the Mahicans at Wyalusing and other Indian communities. To mediate this animosity between these two peoples, Zeisberger settled the Mahicans mostly at Gnadenhutten and the Delawares at the other Muskingum towns. See Mahr, ed., "Canoe Journey," 290. After the American Revolution, western Mahicans became absorbed into the Delaware nation, while eastern Mahicans remained in the Connecticut region. See Thwaites and Kellogg, eds., Revolution on Ohio, 62.

${ }^{41}$ Heckewelder in George Henry Loskiel, trans., Christian Ignatius La Trobe, History of the Mission of the United Brethren Among the Indians of North America in three parts (London: The Brethren's Society, 1794), 3: 57.

42 Gray, Wilderness Christians, 47. Amy C. Schutt contends that from 1767-1781 there were from 350-400 baptized/Christianized/missionized Delawares on the Ohio. Though these numbers are small, the Delaware Christians comprised $12-14 \%$ of the Delaware nation in the west. See Schutt, "Forging Identities," 9.

${ }^{43}$ Hinderaker, Elusive Empires, 182-183.

44 Schutt, "Forging Identities," 200-201. 
small number of Christian Delawares as members of his community. ${ }^{45}$ Despite his reluctance to openly accept the Christian faith, Netawatwees (who would later become a convert) was inspired by the Christian theology of peace and good will, at a time when he wanted his people to reject the influences of the warriors from the surrounding Shawnee, Wyandot, and Seneca towns. ${ }^{46}$

While Netawatwees took a moderate approach and preferred blending aspects of Christianity with traditional spirituality, White Eyes was much more radical. He advocated that Delawares embrace Anglo concepts of progress by breaking away from many of their traditions and customs. ${ }^{47}$ Despite his radical affinity for the white mans' progress, White Eyes gained prominence in the Lupwaaeenoawuk as the leading Delaware proponent of peace and supporter of the Moravian mission towns in the Ohio. The political influence of White Eyes rose in the early 1770s. A once-powerful war captain, he became the chief lieutenant of Netawatwees at Gekelemukpechunk. There, he replaced the Wolf councilor known as Echpalawehund ("He that missed the objects he shot at") as chief speaker of the nation in the Great Council. ${ }^{48}$

The peace-making skill of White Eyes became evident in 1774 when he took a prominent role during the frontier conflict involving the Shawnees and Mingos against Virginia known as Dunmore's War. ${ }^{49}$ Lord John Dunmore of Virginia, with the help of White Eyes, met with

45 Olmstead, Blackcoats Among the Delaware, 52; Sipe, Indian Chiefs of Pennsylvania, 409-413; Weslager, The Delaware Indians, 298.

${ }^{46}$ Olmstead, Blackcoats Among the Delaware, 14.

47 Herman Wellenreuther, "White Eyes and the Delawares' Vision of an Indian State," Pennsylvania History: A Journal of Mid-Atlantic Studies 68 (Spring 2001): 154-155.

48 Ibid., 141. Echpalawehund left the Delaware council and became a Moravian convert baptized as Petrus. White Eyes was also a wealthy Indian trader who had connections with the Gratz Brothers (Bernard and Michael), a trading firm out of Philadelphia.

49 The causes of Dunmore's War can be traced to the Fort Stanwix Treaty in 1768 when the Six Nations relinquished their claims to land south of the Ohio (Kentucky) for white settlement. The Shawnees, who hunted in Kentucky, were not present at the treaty talks and did not recognize the Iroquois land cessions. When Virginia sent surveyors into Kentucky, they were attacked by Shawnee war parties. This caused war on the frontier. The best treatment of this brief frontier war include: Reuben Gold Thwaites and Louise Phelps Kellogg, eds., Documentary History of Dunmore's War, 1774 (Madison: Publications of the State Historical Society of Wisconsin, 1905); Reuben Gold Thwaites, ed., Chronicles of Border Warfare with Reflections, Anecdotes, \&c. by Alexander Scott Withers (1831; reprint, Cincinnati: Stewart \& Kidd Company Publishers, 1895), 135-190; Thomas Perkins Abernathy, Western Lands and the American

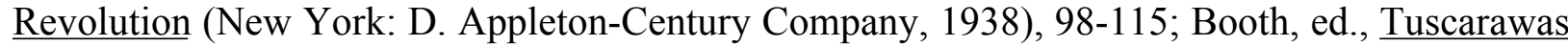
Valley in Indian Days, 157-165; Olmstead, David Zeisberger, 214-231. 
Shawnee and Mingo chiefs at Fort Dunmore (Fort Pitt) in August 1774. Shawnees asked the Delawares to mediate with the British on their behalf. The Shawnees desired an armistice and “open peace negotiations." They "yielded themselves to their grandfather" (White Eyes) and accepted "whatever he would agree upon with the Virginians" as a way to "secure peace."50 Dunmore noted that despite the resistance of the Shawnees, the Delawares "remained Steady in their attachment" to the British. White Eyes offered the Virginia governor Dunmore the "assistance of himself and [the] whole tribe." The governor enlisted White Eyes and three of his warriors. $^{51}$

At the time of Dunmore's War, the Delawares were in a precarious position. If they sided with the Shawnees, they would be the targets of Virginia militia, if they supported the Virginians, the Delawares would violate the "sacred bonds" they had established with their Shawnee allies. If Delawares broke this bond, they would be branded "schwannaks" ("bitter beings") or the Indian equivalent of traitors. White Eyes opted for neutrality as the Delaware position in this frontier conflict. Though he could not stop Virginia's invasion and destruction of the Shawnee upper and lower towns on the Scioto River, he fulfilled his role as "Peacemaker" when he helped to broker the peace settlement between the Shawnees and Virginians at Camp Charlotte in October $1774 .^{52}$

${ }^{50}$ From a journal entry of Abraham Thomas, Aug. 6, 1774, in Booth, ed., Tuscarawas Valley in Indian Days, 161. Lord Dunmore's War was also the result of the collapse of "imperial authority" in the Pittsburgh region. The British altered their trade policies with the Indians in the west from rigid to a lack of control. The Indian department turned over matters of trade to individual traders and land companies. Wishing to ease up on military presence in the west, the British abandoned Fort Pitt in October 1772. The buildings of the garrison were sold to the traders Alexander Ross and William Thompson. Lord Dunmore with the assistance of Dr. John Connolly (a nephew of George Croghan) pressed Virginia's territorial claim in the Ohio by garrisoning militia units at Fort Pitt, renamed Fort Dunmore. By the time of the American Revolution, Dunmore's presence and Virginia's occupation in the region dissipated as American forces took control of Fort Pitt. See Hinderaker, Elusive Empires, 67-69; Abernathy, Western Lands and American Revolution, 152-153; Downes, Council Fires on Ohio, 175, 181-183.

${ }^{51}$ Lord Dunmore in Thwaites and Kellogg, eds., Documentary History of Dunmore's War, 384.

52 Wellenreuther, "White Eyes and the Delawares' Vision," 145-146. At the Camp Charlotte Treaty in 1774, Cornstalk and his Shawnees were forced to acknowledge Virginia's claim to Kentucky. Also see Abernathy, Western Lands and American Revolution, 112. The Mingos failed to attend the treaty and were punished by Dunmore. William Crawford and the Virginia militia destroyed five Mingo towns in the vicinity of present-day Columbus, Ohio. See Olmstead, David Zeisberger, 228. 
Dunmore befriended White Eyes and praised his "faithfulness, and firmness and remarkable good understanding. ${ }^{, 53}$ He asked White Eyes to come to Williamsburg where Dunmore would "draw up a Deed for the Land of the Delaware that they would then take to England for confirmation by the King." 54 Dunmore saw a no-lose opportunity. He hoped that by supporting the Delawares' claim to the Ohio, they would be free of the Six Nations Iroquois and Wyandots as landlords. At the same time, Virginia could be proprietors north of the Ohio and control the region south of the Ohio. Delaware land would then be within the boundaries of an extended Virginia. ${ }^{55}$ White Eyes sent a peace belt to Dunmore, who in turn assured him "that our foolish men shall never be permitted to have your Lands [the Muskingum] but on the contrary the Great King will protect you and preserve you in the possession of them." ${ }^{56}$ The "revolutionary stirrings" in Virginia however, put the Dunmore proposal of a Delaware petition to the King permanently on hold. ${ }^{57}$

White Eyes pushed his agenda for peace and unity as a national policy, through his recognition and support of the Moravian missionaries. However, he suffered many rebukes in his attempt to unify the Delawares around the Moravian Christians. By November 1774, he was placed at odds with Netawatwees and the Great Council, who modified their original tolerance of the Moravian missionaries and their Indian converts. Perhaps trying to save his own chieftainship, Netawatwees secretly considered White Eyes to be one of the "foolish and unreasoning people" who allowed for the contamination of Delaware native beliefs through the intrusions of Christianity. ${ }^{58}$ White Eyes broke council protocol when he tried to initiate his policy concerning full acceptance of the Moravians without council consensus. In a moment of intense passion, White Eyes threw a wampum belt at the feet of the old chief and resigned from the Delaware council. Netawatwees panicked and asked the Moravians to mediate this dispute

\footnotetext{
War, 384.

54 From David Zeisberger's Diary, Feb. 2, 1775, in Wellenreuther, "White Eyes and the Delawares' Vision," 146.

${ }^{55}$ Wellenreuther in ibid., 147.

${ }^{56}$ Dunmore to White Eyes, enclosed in a letter from John Connolly to John Gibson, August 1775, in Pennsylvania Archives, 1st series, Hazard, ed., 4: 683-684.

${ }^{57}$ Wellenreuther, "White Eyes and the Delawares' Vision," 149.
}

${ }^{53}$ Lord Dunmore in Thwaites and Kellogg, eds., Documentary History of Dunmore's 
and to coax White Eyes back into his position as spokesman. White Eyes was the right hand man of Netawatwees, regarding council affairs, and this resignation had great bearing on swaying the old chief's position on the Moravians. According to Zeisberger, "White Eyes's opinion counts the most in the Council. The chief does nothing without him." 59 At that time, he had the "greatest influence among the Delaware." overridden in the Lupwaaeenoawuk. ${ }^{61}$

Through the pressure of White Eyes, Netawatwees welcomed Moravians to the Muskingum and promised Zeisberger the "protection of the Unami Delawares," as these praying towns mostly comprised Turtle and Turkey Delawares and were located near militant Shawnee and Mingo communities. ${ }^{62}$ The Council also acknowledged the rights of the converts as Delawares. $^{63}$ On February 28, 1775, White Eyes "professed, in the name of the entire nation," an acceptance of the Christian faith among all Delawares. ${ }^{64}$ He warned his fellow Delawares "if they were to harm Christians, so would they be harming God." ${ }^{65}$ Sensing a council consensus in this matter, Netawatwees told a fellow chief:

58 August Carl Mahr, trans., “Zeisberger's Schoenbrunn Diary, 1772-1777,” manuscript collection 215, 92a, Columbus: Historical Society of Ohio.

59 Gregory Schaaf, Wampum Belts \& Peace Trees: George Morgan, Native Americans, and Revolutionary Diplomacy (Golden, Colorado: Fulcrum Publishing, 1990), 80-86; Olmstead, David Zeisberger, 230-231; Schutt, "Forging Identities," 202. Gregory Schaaf maintains that White Eyes, to gain his goal of uniting traditional Delawares with Christian converts had to be humbled enough to approach the council with deference and to win a consensus through proper diplomacy.

${ }^{60}$ David Zeisberger, May 10, 1774, in Hernhutter Indianermission in der Amerikanischen Revolution, Die Tagebucher von David Zeisberger, 1772-1781, eds., Hermann Wellenreuther and Carol Wessel (Berlin: Akademie Verlag, 1995), 194.

${ }^{61}$ Schaaf, Wampum Belts \& Peace Trees, 80-86; Olmstead, David Zeisberger, 230-231; Schutt, "Forging Identities," 202.

62 Zeisberger quoted in Gray, Wilderness Christians, 47.

63 Mahr, trans., "Schoenbrunn Diary," $101 \mathrm{~b}$.

${ }^{64}$ White Eyes and the Delaware Great Council, Feb. 28, 1775, in August C. Mahr, trans., Schoenbrunn Story: Excerpts from the Diary of The Reverend David Zeisberger, 1772-1777 at Schoenbrunn in the Ohio Country (Columbus: The Ohio Historical Society, 1972), 15.

${ }^{65}$ White Eyes in Schutt, "Forging Identities," 199. Schutt in pages 197-201 of her dissertation emphasizes that White Eyes did not advocate Moravianism solely for spiritual motives. He believed that Christianity could make the Delawares more powerful. White Eyes was not a convert and at one time considered bringing Anglican missionaries into the Ohio if the 
You and I are both old. Let us do a good work, before we depart, and leave a testimony to our children and posterity, that we have received the word of God. Let this be our last will and testament. ${ }^{66}$

David Zeisberger was less optimistic regarding the co-existence of Christian and traditionalist Delawares on the Muskingum. He reminded the Delaware Council that:

If you agree to having the Gospel preached here, those who want to hear it, must live by themselves. Here in this town [the traditionalist town of Coschocton] there is nothing but gambling, dancing and drinking and constant noise, therefore it is imperative for us to have a place to ourselves where we are isolated away from the noise, and unmolested, so that those who want to hear the word of God can come and those who prefer their heathendom, can stay away. ${ }^{67}$

The Moravian missionaries preferred this separation as a means to assimilate Christian Delawares into white society, and as a way to resist what they considered to be the destructive influence of non-Christian Indians. ${ }^{68}$ Zeisberger disapproved of the non-Christian Delawares who lived in proximity to the Moravian towns. He saw them as being "lazy as far as work [was] concerned." He observed that if men were not hunting they would "lie all day on their britche[s] and sleep; when night [came] they [would] dance or wander about in disorderly fashion." ${ }^{69} \mathrm{He}$ opposed the social mores of many unconverted Delawares, for "so long as [they] lived on the

Moravians failed to aid his political aims of unifying the Delawares. However, White Eyes was emotionally moved by the paintings he saw depicting the crucifixion and resurrection of Christ.

${ }^{66}$ Chief Netawatwees in Loskiel, History of the Mission, 3: 102-103.

67 Zeisberger in Booth ed., Tuscarawas Valley in Indian Days, 98.

68 Ralph Mark Radloff, "Moravian Mission Methods Among the Indians of Ohio"

(Ph.D. diss., The University of Iowa, 1973), 86.

69 Ibid., 18. 
Muskingum, they used all sorts of devices" to lure his converts away from the mission settlements and back into the traditionalist Delaware towns. ${ }^{70}$

Throughout the mid 1770s, there was increasing social breakdown in many non-Christian Delaware towns. On his visits to these villages, Zeisberger witnessed an "impurity and immorality, even gross sensuality" after traders entered the towns with rum. ${ }^{71}$ Zeisberger, in turn, could not always prohibit visitors to his towns. With the corrupting influences of alcohol and the oncoming American Revolution bringing warriors into the Delaware and Moravian towns, isolation of these communities became increasingly difficult. Peaceful seclusion was needed to establish both the utopian Christian Indian communities on the Muskingum and to strengthen the unity of the fledgling Delaware nation.

Certain civil leaders within the Great Council saw the negative influences as a disruption to social and political cohesion. One prominent chief threatened to live with the Moravians, if the council would not purge all communities of drinking and gambling. Missionary John Ettwein explained that the headman's departure would have "made a great Stirr" in the town "for he was highly loved \& honoured by the Chiefs and all the Delawares." The Delaware council decided to reform the community by banishing "all games and the Traders who taught them to play at Cards \& Dice." The Delaware Lupwaaeenoawuk also banned the sale of alcohol in their towns and appointed six men to destroy the ten kegs of rum, which traders had recently brought to Newcomerstown. ${ }^{72}$

The Delaware Great Council, spearheaded by the visions of White Eyes and Netawatwees, gravitated towards Moravianism and social reform as an implement to build a strong Indian nation. White Eyes saw Christianity as an anchor for Delaware society. In the Ohio

70 David Zeisberger in Eugene F. Bliss, ed., Diary of David Zeisberger: A Moravian Missionary Among The Indians of Ohio 2 vols. (Cincinnati: Robert Clark \& Co., 1885), 1: 27.

71 Zeisberger in Hulbert and Schwarze, eds., "Zeisberger's History," 20.

72 John Ettwein in Kenneth G. Hamilton, "Cultural Contributions of Moravian Missions among the Indians," Pennsylvania History 17 (1951): 14-15. The men appointed by the Delaware council were known as "morality guards." For a short period many of the nativist Delaware towns were as pro-temperance as were the Christian Delaware towns. See Gray, Wilderness Christians, 51. 
Valley, Delawares sought to create a new utopian world; a Delaware version of what Puritans called, the "Citty upon a Hill.", 73

Delawares also believed that by remaining neutral during the Revolution, they could secure the goods they needed from Americans at Fort Pitt and spare their people the violence that had taken place against the Shawnees during Dunmore's War. White Eyes and other civil chiefs were "yet determined to stand fast and not to meddle with the War . . . [and] to live in friendship" with their American neighbors. ${ }^{74}$ The Delaware Great Council embraced Moravianism as a way to mobilize political and economic integration with their American neighbors in the Fort Pitt region. In doing so, they would enhance this new social environment and gain control of national destiny. ${ }^{75}$ These Christian communities offered "new sources of spiritual strength and community resilience" as Delawares faced the reality that their environment was slowly "becoming a white man's world.", 76

Despite the ideals of peace and neutrality as the base for the stability of the Delaware nation, the American War for Independence indeed slowly seeped into the Ohio. With the start of the conflict between Great Britain and the American colonies, Delaware chiefs confronted two choices. They could choose sides (many of the neighboring western tribes such as the Wyandots, Ottawas, Shawnees, and Mingos became military allies of the British who were headquartered at Detroit) or remain neutral. Delaware council leadership, guided by White Eyes and the United Brethren, decided on neutrality in this turbulent and dangerous region. ${ }^{77}$

73 The phrase "Citty upon a Hill" can be attributed to John Winthrop, the Governor of Massachusetts Bay Colony in 1630. See John Winthrop, "A Modell of Christian Charity" in David A. Hollinger and Charles Capper, eds., The American Intellectual Tradition: Volume 1, 1630-1865 (New York: Oxford University Press, 1993), 15.

${ }^{74}$ Zeisberger to General Edward Hand Sept 22, 1777, in Reuben Gold Thwaites and Louise Phelps Kellogg, eds., Frontier Defense on the Upper Ohio, 1777-1778 (Madison: Publications of the State Historical Society of Wisconsin, 1912), 94-95.

75 Dowd, A Spirited Resistance, 20.

${ }^{76}$ Colin G. Calloway, New Worlds For All: Indians, Europeans, and the Remaking of Early America (Baltimore: The Johns Hopkins University Press, 1997), 90.

${ }^{77}$ Weslager, The Delaware Indian Migration, 37. The Wyandot nation was comprised of Indians of the Huron Confederacy and the Petuns, both of whom were almost eradicated by the Five Nations of Iroquois during the "Beaver Wars" of the seventeenth century. Wyandots were Iroquoian speakers and resided in the Detroit/Windsor area and northern Ohio (Sandusky) regions. See the entry for "Huron/Wyandot" by Olive Patricia Dickason in Frederick E. Hoxie, 
In October 1775, White Eyes severed his diplomatic ties with Governor Dunmore and situated the Delawares as noncombatants in the escalating tensions between the British government and American colonists. Diplomatically he realized it was in the best interest of his people to have friendly relations with the Americans and distance themselves from the Britishappointed governor of Virginia. $^{78}$

White Eyes and a delegation from the Lupwaaeenoawuk met with Continental Congress officials of Indian affairs and several other Indian nations at Fort Pitt in October of 1775. This conference was a pinnacle event in Delaware Indian history. It was there that White Eyes asserted both Delaware consensus as neutrals and total independence, as a sovereign nation, from the Council Fire at Onondaga. On October 9, White Eyes declared to the American commissioners "that they [the Delawares] would remain neutral, during the contest between Parent and the Son--and not lift up the Hatchet against either side." ${ }^{\text {79 }}$ He demanded that the homeland of his nation include the Muskingum to the "Mouth where it Empties into the Ohio and up the said River to the Place of Beginning." ${ }^{80}$ To keep in the good graces of the Americans, he promised the commissioners that he would keep his young men from hunting in Virginia and would keep them "planting Corn in their Own fields" on the Muskingum. ${ }^{81}$ White Eyes, with astute diplomacy, also masked the discontent of a pro-Seneca Wolf faction of Delawares who were shouted down at the great Council fire. Leaders of the Wolf tribe, because of a historical and geographical attachment to the Senecas, were quick to dissent against any oratory that might estrange them from the Six Nations. To minimize the relevance of the anti-American faction, White Eyes referred to them metaphorically as our "foolish young men." 82

The Six Nations Iroquois made a last attempt to rekindle dominance over their former tributaries. Kiashuta of the Senecas addressed the Delawares "in a haughty tone" and reminded them that the Delawares "had no will of their own, but were subordinate to the 6 Nations."

ed., Encyclopedia of North American Indians (Boston: Houghton Mifflin Company, 1996), 263265.

78 Wellenreuther, "White Eyes and the Delawares' Vision," 150-152.

79 Ibid.,150-151; Heckewelder, Narrative of the Mission, ed., Connelley, 258.

${ }^{80}$ White Eyes at Fort Pitt Conference, Oct. 9, 1775, in Thwaites and Kellogg, eds., Revolution on Ohio, 87.

${ }^{81}$ White Eyes, Oct. 11, 1775, Fort Pitt Conference in Calloway, ed., Revolution and Confederation, vol. 18 of Early American Indian Documents, Vaughan, general ed., 107. 
White Eyes, "long since tired of this language," rose and in a forceful bit of Lenape oratory, challenged Kiashuta's desperate pretensions:

You say that You had conquered me [the Delawares]-that You had cut off my Leg's-had put a Petticoat on me, giving me a Hoe and Corn pounder in my hands, saying: now Woman! Your business hence forward shall be to plant-hoe Corn, and pound the same for Bread for us Men and Warriors!

Look! at my Legs! if as you say You had cut them off, they have grown again to their proper size! the Petticoat, I have thrown away, and have put on my proper dress! The Corn hoe and pounder I have exchanged for these fire Arms, and I declare, that I am a Man! and all the Country on the other side of that River [Ohio] is mine. ${ }^{83}$

White Eyes, correctly, believed that the Senecas would support Great Britain and fight against the Americans. In the interim, he believed that if the Six Nations attacked the Delawares, they would receive help from the Americans. He also hoped that the Iroquois would "therefore lose the Land they had so artfully wrested from the Delawares." 84

At the peace talks at Fort Pitt, White Eyes proclaimed a Delaware political nation when he told the commissioners: "we now inform you that there are three tribes of us Kalalamint [Gelelemend or John Killbuck of the Turtles] Walapachakin [Captain Johnny of the Turkey tribe] and Ohokon [Captain Pipe of the Wolf phratry]." Together with White Eyes as chief spokesman, they were the chiefs "Appointed for the Delaware Nation." 85

${ }^{82}$ White Eyes, October 1775, in Hinderaker, Elusive Empires, 208.

${ }^{83}$ Speech of White Eyes to Six Nations delegation, Fort Pitt Conference, Oct. 9, 1775, in Heckewelder, Narrative of the Mission, ed., Connelley, 258; Heckewelder, An Account of the Indian Nations, 68-70.

${ }^{84}$ Heckewelder in ibid., 258-259.

85 White Eyes at Fort Pitt Conference, Oct. 9, 1775, in Thwaites and Kellogg, eds., Revolution on Ohio, 88. John Killbuck or Killbuck Jr., the son of the Wolf war leader Captain Kill Buck (Bemineo), was also the grandson of Netawatwees. Kill Buck Sr. became blind in his later years and died in 1779 or 1780 . See biographical and geographical glossary in Wallace, ed., Travels of Heckewelder, 419, 427; Sipe, Indian Chiefs of Pennsylvania, 419; Weslager, The Delaware Indians, 228, 236, 272, 289-290. 
Unlike the Bouquet talks in 1765 when the phratry heads had to humble themselves in order to receive a favorable peace, the Fort Pitt talks of 1775 demonstrated a Delaware nation of diplomatic confidence--with political strength and influence. Beneath the veneer of regional prominence, however, was a fragile state of union among the three tribes. White Eyes had much to do with building consensus and strengthening the nation. Yet as a leader with a vision for the Delawares, he would have to deal with the dissent of those in the Great Council who did not share in this dream.

White Eyes as the chief councilor of Netawatwees, who was still recognized as head of the nation, became highly regarded for his oratorical and diplomatic skills. Once a decentralized people of autonomous bands, the Delawares at this time appeared to have accepted not only political solidarity but also established a certain hierarchy among the three phratries. The Turtles gained a new preeminence over the Wolf and Turkey tribes. Zeisberger implied this when he observed that among the Delawares, a "message sent or a speech in council goes or is delivered in the name of the three tribes, signifying the three chiefs. The Turtle is named first, next the Wolf Tribe and the Turkey Tribe last." 86 Zeisberger contended that only a Turtle could be the principal leader of the nation. Yet during the Seven Years' War, Tamaqua and Shingas had previously held this position, despite their Turkey lineage. ${ }^{87}$ Here Zeisberger erred in his observations. The three tribes had never acted together as a national entity. Those Delawares who addressed colonial officials, were always Unami speakers. The Wolf and Turkey division may have ceded the dominant position to the Turtles with the selection of Netawatwees as the principal sachem. This may have been a temporary arrangement to accommodate the Delaware

${ }^{86}$ Zeisberger in Hulbert and Schwarze, eds., “Zeisberger's History," 111.

87 The ascension of the Turtles as the preeminent (if not dominant) group may also be based partly on northeastern woodland Indian oral traditions in which the Turtle represented creation and Mother Earth--both highly sacred. C. A. Weslager implies that it also was of a political convenience. For a discussion of the hierarchy of the animal divisions within Delaware political structure, see Weslager, The Delaware Indians, 292. This in itself was a violation of Delaware protocol. Delawares, when they chose a principal man of the three phratries, always selected a member of the Turtle clan. In Delaware hierarchy, the Turtle tribe was the highest ranked among the three animal tribes. In Delaware oral traditions, there is a story in which the Turtle, Turkey, and Wolf attempt to get the food they see on the other side of a riverbank. Only the Turtle could swim across to get this food. Therefore the Turtle would be forever considered to be the best of the three. See Sipe, Indian Chiefs of Pennsylvania, 288; John Bierhorst, story 
capital being moved in 1776 to Goschachgunk, a Turtle stronghold. Certainly the rising status and influence of White Eyes also contributed to the high ranking of the Turtle group.

White Eyes' rhetoric of independence from the Six Nations, however, disturbed Captain Pipe and the Wolf tribe who had a closer relationship with the Iroquois (western Senecas) than did the Unami-speaking Turtles and Turkeys. They in fact were concerned that the Six Nations would try to assert their authority over the Delawares on the Muskingum. Shortly after the talks at Fort Pitt and with much consternation, Pipe withdrew from the council and removed his people from the forks of the Muskingum and moved west to the Walhonding, located fifteen miles from Goschachgunk. Newalike and the Munsee Christians who resided at the Moravian mission town of Schoenbrunn followed Pipe's secession from the centralized cluster of Delaware towns. Newalike took his followers north to the Lake Erie region. John Heckewelder maintained that Pipe "was glad to see a breach made, of which White Eyes was to bear the blame." $\mathrm{He}$ believed that Captain Pipe made a push for power using White Eyes' support of the Americans as a pretense to remove his Wolf Delawares "from the Councils of the Turtle tribes." 88

Netawatwees used the influence of Munsee-Wolf converts Glikhikan and Echpalawehund, both highly-regarded as war captains and councilors, to mediate the schism between White Eyes and Captain Pipe. Temporarily, a delicate reconciliation of emerging political factions was reached between the two. ${ }^{89}$ Pipe, from his new location, "pretty regularly attended the Councils," though he was increasingly moving away from the consensus of the civil leaders and their push for peace. ${ }^{90}$ Pipe's temporary resignation from the Lupwaaeenoawuk may have been symbolic--a form of protest against White Eyes' cavalier and potentially dangerous treatment of the Six Nations Iroquois at Fort Pitt. Despite the withdrawal of the Wolf

no. 73, "Why the Turtle Phratry is Best" in Mythology of the Lenape: Guide and Texts (Tucson: University of Arizona Press, 1995), 92.

${ }^{88}$ Heckewelder, Narrative of the Mission, ed., Connelley, 260. Also see De Schweinitz, Life and Times of Zeisberger, 438.

${ }^{89}$ Schutt, "Forging Identities," 138; Olmstead, David Zeisberger, 230-232.

${ }^{90}$ Heckewelder, Narrative of the Mission, ed., Connelley, 261. Thus began the continuous movement of the Wolf-Munsee group of Delawares. By 1778, Captain Pipe and his followers lived in the Cuyahoga River region of northern Ohio with the western Senecas. His Wolf tribe then moved further west to the Upper Sandusky area in November of 1778, to be closer to the Wyandots and out of the path of marauding western Indian nations. See Olmstead, David Zeisberger, 290. 
group from Goschachgunk, the Delaware peace chiefs among the Turtles and Turkeys "pursued their usual course, their sole Object being the welfare of the Nation." 91

White Eyes appeared before the Continental Congress in December of 1775 to ask them to provide the Ohio Delawares with a teacher and a blacksmith and to gain assurances that Americans would not settle in Delaware country. If the American Congress could guarantee these requests (and they could not), White Eyes assured them that he would keep his men peaceful. ${ }^{92}$

Anti-Americanism among the western Indian nations, however, intensified. The Delaware policy of peace and neutrality became harder to maintain as outside agitations brought great pressure to the Great Council at Goschachgunk. As early as the fall of 1775, it was rumored that over 1,500 Chippewas and Ottawas had converged on the Tuscarawas "with the probable purpose of an attack on Fort Pitt." ${ }^{93}$ In August of 1776, County Lieutenants at Fort Pitt were warned of a great western confederation of Indian nations prepared to swarm out of the Detroit region to ravage the Delaware towns on the Muskingum and the Americans at Fort Pitt. ${ }^{94}$

Killbuck, the civil chief of the Turtle tribe, warned Major John Anderson of Fort Pitt that bands of Cherokees, Wyandots, Ottawas, Chippewas, Potawatomies, and Mingos were "united as one nation" and were prepared to "strike the Big Knife." ${ }^{95}$ A Wyandot delegation came to Goschachgunk to press the Delawares to abandon their neutrality and to strike the Americans on behalf of the British and western confederation of Indians. Killbuck reminded the Wyandots that "When you gave us this Land, \& [when] the Council fire was kindled here you told us to hold

91 Heckewelder in Narrative of the Mission, ed., Connelley, 261.

92 Max Savelle, George Morgan: Colony Builder (New York: Columbia University Press, 1932), 135. It was in Philadelphia during his address to the Continental Congress, that White Eyes struck a friendship with George Morgan, a trader and former agent for the Indiana Land Company. At that time, Morgan served the Delawares as counselor. In April 1776, Congress elected Morgan as agent for Indian Affairs in the Middle Department. Morgan resided at Fort Pitt and was under the direction of the Indian Commissioners. The Delawares thought highly of him and referred to him as Tamenend (in honor of the past great sachem by the same name).

Tamenend meant the "affable one" in the Unami dialect. See Savelle, George Morgan, 136-137.

${ }^{93}$ Commissioner of Indian Affairs at Pittsburgh to the Continental Congress, September 25, 1775, in Thwaites and Kellogg, eds., Revolution on Ohio, 199.

${ }^{94}$ Commissioner of Indian Affairs, Thomas Walker and John Harvie to County Lieutenants at Fort Pitt, August 31, 1776, in ibid., 190.

95 Intelligence report of Major John Anderson, Fort Pitt, October 12, 1776, in George Morgan, Colonel George Morgan Letter Books: 1769-1779, 3 vols. Carnegie Library, Pittsburgh, Pennsylvania, Book 2: 61. 
fast to the Chain of Peace \& Friendship" and not to be swayed to "anything but Peace." He told them that the Delawares would follow the advice of the "Virginians" and "sit still \& be quiet. ..." 96

In the fall of 1776, the Lupwaaeenoawuk underwent a transformation. The ancient Netawatwees died on October 31. John Killbuck, as the matrilineal hereditary successor to his grandfather's position, became head chief of the Turtle tribe but refused to become the principal leader of all Delawares. White Eyes, because of his senior status and influence, became the primary ranking civil chief of the Delaware nation. ${ }^{97}$ The Great Council, with White Eyes "ruling it," also agreed to the ascension of Captain Johnny as head chief of the Turkey tribe, to replace the deceased Tamaqua. Pipe remained the head chief of the Wolf phratry. ${ }^{98}$

It was of the utmost importance that the Great Council remain on its trajectory of guiding the nation to peace, unity, and strength despite the increasing animosities between White Eyes and Pipe and the violent atmosphere of the Ohio Valley. In the early part of 1777, the western frontier became a volatile region for those Americans fighting for independence. Because of the violence of Indian raids and American retaliation, Delaware neutrality became greatly challenged. In January, George Morgan reported to Congress that the Senecas, goaded by the British, alleged that they had warned off American frontiersmen at Venango, near the forks of the Allegheny River. The Senecas delivered a message along with a war hatchet and the dead body of a frontiersman. The note read: "the lands are ours and we insist on your quitting them immediately." ${ }^{99}$ In February of that year, the Mingo war leader named Pluggy, together with a small group of renegade Delawares led by Catfish, and Shawnees and Wyandots raided settlements in Kentucky. ${ }^{100}$ Delawares felt the stress of the escalating hostilities on the

${ }^{96}$ Killbuck to Wyandots at Goschachgunk, November 21, 1776, in ibid., 1: 18.

${ }^{97}$ Thurman, "Delaware Indians in Ethnohistory," 99-100. Netawatwees was ninety-eight years old at the time of his death. See biographical and geographical glossary in Wallace, ed., Travels of Heckewelder, 427; with regard to matrilineal succession see page 47, footnote 4 .

${ }^{98}$ Observations of Jasper Yeates at Fort Pitt in 1776, in Thurman, "Delaware Indians in Ethnohistory," 100.

${ }^{99}$ Morgan to Congress, January 4, 1777, in Thwaites and Kellogg, eds., Revolution on Ohio, 245; Downes, Council Fires on Ohio, 202.

${ }^{100}$ Hinderaker, Elusive Empires, 209; Calloway, American Revolution in Indian Country, $32,60,165$. Pluggy was a charismatic Mingo leader who attracted renegade warriors from many 
periphery of the Muskingum. White Eyes informed the commissioners at Fort Pitt that the enemies of Americans were the "Banditti" of the Mingoes, \& the Wiandots of Sandusky \& Detroit." He also showed concern for the few Delawares who had "been deluded by them" to take up the hatchet against Americans. ${ }^{101}$

Amidst the growing tensions in the west, White Eyes and the Great Council held together the consensus of neutrality for the Delawares. The Wolf tribe, true to its nature of a "rambler," remained outside of the Turtle-Turkey tribes at Goschachgunk. The Wolf council, nevertheless, had enough influence and a strong martial presence to pull the nation from its neutral stance into the sphere of the anti-American Senecas. Pipe, for the time being, allowed for the peace-making efforts of White Eyes and the Moravians to materialize as a way to stabilize a peaceful environment for the Delaware nation. At that time the nation was best served by the vitality of the Great Council and the symbiotic relationship established between the visionary White Eyes, the Delaware peace chiefs, and the Moravian faith. Eventually the American Revolution entered the Ohio and greatly challenged and strained this arrangement of accommodation and cooperation between Delaware civil leadership in the Great Council and Americans at Fort Pitt.

Indian nations of the region. They congregated at Pluggy's Town located at the horseshoe bend of the Olentangy River near current-day Columbus, Ohio.

${ }^{101}$ White Eyes to commissioners, as relayed by Morgan to John Hancock of the Continental Congress, Fort Pitt, March 9, 1777, in Morgan Letters, 1: 55-56. 


\section{Chapter V}

\section{The Delawares and the American Revolution}

Throughout 1777, the British and their Indian allies misread Delaware neutrality as support for the United States. This stance put them in a precarious state, for pro-British tribes of the west had taken the hatchet against Americans who bordered the Delaware homeland. Virginia Governor Patrick Henry acknowledged the dangerous position in which the Delawares had found themselves. He was concerned that the Delawares were in great danger "on account of their Fidelity" to the Americans. Henry ordered the county lieutenant of Ohio to "use every means in your power to protect them." Henry added that if the Delawares wanted forts constructed, this was to be done. The lieutenant was to use the Virginia militia to "defend [these] faithfull allys to the last Extremity. Any Injury done them, is done to us. In one Word, support protect \& cherish them in every Respect to the utmost."

As the conflict of the American Revolution reached the west, Delaware nationhood was put to the test. It was expedient for the Great Council to agree upon a policy that would serve to protect and preserve the Delaware nation. However, any consensus within the Lupwaaeenoawuk was greatly strained by the increasing animosity between White Eyes and Captain Pipe. Both recognized that neutrality was the best course for a fledgling nation--the means to attain this was the point of contention between the two councilors. Eventually the changing political environment in the west, altered by many factors, ended the influence and preeminence of the Turtle and Turkey phratries as the navigators of policy. This period also challenged the Great Council's decision to emulate Moravian values of pacifism as the politico-social order of the Delawares. Captain Pipe and the Wolf tribe steadily increased the opposition to the TurtleTurkey pro-American and Moravian position. He and his supporters eventually took advantage of a political shift on the Muskingum and high jacked the political direction of the Delaware nation, bringing them into a union with the western Indian nations and their British allies.

${ }^{1}$ Patrick Henry to the County Lieutenant of Ohio, Williamsburg, March 27, 1777, in Thwaites and Kellogg, eds., Revolution on Ohio, 244-245. 
The Ohio Delawares were strategically located in a region that made them geo-politically important to many parties. Their towns on the Muskingum were enclosed between the western Indian nations and their British allies at Detroit and the Americans at Fort Pitt. George Morgan, the Indian agent at Fort Pitt, was a steadfast friend of the Delawares, and saw that the pressure was great on the Lupwaaeenoawuk of the Delawares to join the cause of the anti-American western tribes. Morgan noted that during a council with the British at Detroit in November of 1777, Captain Pipe and the Wolf council refused the overtures of Detroit Governor Henry Hamilton to join the British cause. Hamilton offered bounties of "very high prices" for the scalps of whites taken on the American frontiers of Virginia and Pennsylvania. He also encouraged Indian allies of the British to attack Delawares who were friendly towards the Americans at Fort Pitt. ${ }^{2}$ Pipe told the British that the "Big Knife [Americans] are our Neighbours and we live in friendship with them. They \& we have lately renewed our friendship \& we wish it to last for ever." Regarding the Revolution, Pipe assured the British of Delaware neutrality: "We are a free $\&$ independent Nation, we are in friendship with all Nations \& we desire to remain so \& we particularly wish to live in friendship with you." 3 While Captain Pipe and the Wolf Delawares favored the British (as the Turtle-Turkey group of White Eyes, Killbuck, and Captain Johnny favored the Americans), he was committed to keeping the Delawares neutral as he maintained that his people would not gain from taking sides. Pipe mentioned to Hamilton "They [Americans] have explained to us the Nature of their Quarrel one Way. You explain it another but we have Nothing to do with it."

The Delawares also alienated themselves from other tribes. They refused the war belt offered to them by the Wyandots in July of 1777. The Delawares contended that they "would never fight no more against the white people as long as the Sun shineth \& the River run." The Delaware council advised the Wyandots to remember the past and to "reflect on the misery they

2 Information conveyed by an American spy in Detroit, October 1777, in Thwaites and Kellogg, eds., Frontier Defense on Ohio, 231-232; Savelle, George Morgan, 153-154. Americans referred to Hamilton as the "hair buyer."

${ }^{3}$ Speech of Captain Pipe to the British at Detroit, November 1777, in Thwaites and Kellogg, eds., Frontier Defense on Ohio, 115. Both David Zeisberger and George Morgan helped Pipe and Killbuck with the speeches they presented to the British at Detroit.

${ }^{4}$ Ibid., 115. 
had brought upon themselves" when they took an "active part" in the Seven Years' War. ${ }^{6}$ When over two hundred Wyandots and Mingos struck settlements on the Virginia frontier in August of 1777, they returned home by crossing through a Delaware town on the Muskingum, and taunted the Delawares, deriding them by calling them Virginians. They said "with great Joy, it would not be long that this Town [the Delaware village] would be no more." 7 Captain Pipe told Morgan that the Wolf- Munsees were constantly pressured by the Genessee or Chenussio Senecas to join them in striking the American frontiers. Pipe maintained that the Wolf Munsees would be "directed by the Delaware Council" to "preserve Peace and Friendship with the United States." 8 David Zeisberger reported to General Edward Hand (then commander at Fort Pitt) in November 1777, that a party of Canadian traders came into Captain Pipe's town at Cuyahoga in northern Ohio. They coerced forty Wolf Delawares to take up the hatchet and go with them to attack settlements in Ligonier, Pennsylvania. Captain Pipe "met them on the road" and chastised the traders by telling them "they were only servants, \& had no power to hand the tomahawk to them" [his warriors]. The war party turned back with Pipe. ${ }^{9}$

Because of this instigation directed at the Delawares to join the western confederacy, Zeisberger informed General Hand that they needed the intervention of the American army to secure Delaware country from the western Indian nations. Zeisberger considered this to be the Delawares' only hope, for without American presence, he believed they could not exist as a nation of peace. ${ }^{10}$ Despite the need for these outposts, the Delawares were also quite uneasy about soldiers in their country. As far back as 1776, White Eyes had "asked the Americans to aid his tribe . . . to build a strong fort to protect them from the western tribes, whom they fear will

${ }^{5}$ David Zeisberger to General Edward Hand at Fort Pitt, July 29, 1777, in Thwaites and Kellogg, eds., Frontier Defense on Ohio, 28.

6 Heckewelder, Narrative of the Mission, ed., Connelley, 265.

${ }^{7}$ White Eyes to Morgan, September 23, 1777, in Thwaites and Kellogg, eds., Frontier Defense on Ohio, 100.

${ }^{8}$ A message from Morgan to the Delaware council at Goschachgunk, April 5, 1777, in Morgan Letters, 1: 78-79.

${ }^{9}$ Zeisberger to Hand, Goschachgunk, November 16, 1777, in Thwaites and Kellogg, eds., Frontier Defense on Ohio, 164-165.

${ }^{10}$ Zeisberger to Hand, July 29, 1777, in ibid., 28. 
attack them because of their friendship for the colonists." ${ }^{11}$ But White Eyes also asked Congress that if an "Army should march" and strike Detroit, "it should take its march above \& below our Towns that our Women \& Children might remain quiet \& not be too much frightened." ${ }^{2}$ There were constant rumors that the American army, on its expedition to Detroit, would also strike the Delaware towns. This rumor "set all the Indians in consternation \& fear, expecting everyday that they will be upon them." ${ }^{\prime 13}$ Hand reassured the Delawares that his soldiers would not harm their people and that his troops would remain on roads outside of the town. ${ }^{14}$

Uneasiness among the Delawares was justified. In an ironic incident, it was Hand and his command that attacked a Munsee-Wolf encampment, forty miles north of Fort Pitt in January 1778 , only to find a few men, four women, and a boy making salt. Referred to as the "Squaw Campaign," most of the noncombatants were killed in this tragic military action, including the brother of Captain Pipe. ${ }^{15}$ George Morgan accused Hand's militia of striking this group when they could "find no hostiles" and that they took the two surviving women for a "reward of 100 Dollars for every Prisoner who should be brought in."16 The outrageous attack led Delawares to question the neutral stance of the Great Council.

By the spring of 1778 , the Delaware neutrality policy became further challenged by the propaganda of three American Loyalist deserters from Fort Pitt who took residence at Detroit. Alexander McKee, an ex-British Indian agent, the trader Matthew Elliot, and Simon Girty, an Indian interpreter, continually visited the Delaware council to convince the leaders that the United States was preparing for a preemptive strike of the Delaware towns. ${ }^{17}$ McKee told the

${ }^{11}$ Report of Commissioner of Indian Affairs, William Wilson at Pittsburgh to the Continental Congress Sept. 25, 1776, in Thwaites and Kellogg, eds., Revolution on Ohio, 203204.

${ }^{12}$ White Eyes message to the Continental Congress, Goschachgunk, September 22, 1777 , in Thwaites and Kellogg, eds., Frontier Defense on Ohio, 97.

13 Zeisberger to General Hand, Goschachgunk, September 22, 1777, in ibid., 94

14 Hand to White Eyes, Fort Pitt, October 1, 1777, in ibid., 113-114.

15 Wallace, ed., Travels of Heckewelder, 130-131; Downes, Council Fires on Ohio, 211.

16 George Morgan to Board of War, July 17, 1778, in Louise Phelps Kellogg, ed., Frontier Advance on the Upper Ohio, 1778-1779 (Madison: Publications of the State Historical Society of Wisconsin, 1916), 113. Also see White, The Middle Ground, 384-385.

${ }^{17}$ Savelle, George Morgan, 154. Congress levied charges of treason against Morgan since he had used Elliot and McKee as agents. A Congressional Committee later cleared him. See 
Delawares that the British destroyed American armies in the east, that General Washington was killed, all members of Congress were hanged as traitors, and that the British controlled all territory east of the Alleghenies. He also informed them that those Americans who escaped the British were now preparing to invade the Ohio and kill all the Delawares, including women and children. ${ }^{18}$ Many of the Wolf Delawares of Captain Pipe, perhaps sensitized by the Squaw Campaign, were swayed by this propaganda. The Wolf warriors prepared for war. ${ }^{19}$

Heckewelder informed White Eyes that all of McKee's assertions were lies. In April of 1778, the Great Council met in Goschachgunk. Captain Pipe, who had moved his people from the Goschachgunk region to live further west on the Walhonding, came to the talks to address the Delawares. He validated the anti-American claims of the three loyalists. White Eyes then addressed the Lupwaaeenoawuk and, with an eye on Captain Pipe, reminded them that:

He [White Eyes] had taken peace measures, in order to save the nation from utter destruction. But if they believed that he was in the wrong, and gave more credit to vagabond fugitives [McKee, Girty, and Elliot], whom he knew to be such, than to himself, who was best acquainted with the real state of things, -- if they had determined to follow their advice, and go out against the Americans, he would go out with them ... he would himself lead them on, place himself in the front, and be the first who should fall. ${ }^{20}$

White Eyes then displayed a copy of a newspaper that Heckewelder had read to him, with the details of the American victory at Saratoga in October of 1777. He announced to the

Savelle, George Morgan, 149; Thwaites and Kellogg, eds., Frontier Defense on Ohio, 184-187, 250, 254-257, 276-277.

${ }^{18}$ Heckewelder, Narrative of the Mission, ed., Connelley, 301.

${ }^{19}$ Ibid., 301. William Smith, Expedition Against the Ohio Indians (1765; facsimile reprint, Ann Arbor, Michigan: University Microfilms, Inc., 1966), 40. According to Smith and Heckewelder, Delaware warriors shaved their heads, with the exception of a tuft of hair on top, daubed with tallow. Their scalp locks were also adorned in the traditional warrior style with the plume of an eagle. Most warriors carried a "rifle, a powder horn, a shot pouch, a tomahawk, and a scalping knife hanging [from] their neck." 
Delaware chiefs and war captains, "See my friends and relatives: this document containeth great events; not the song of a Bird, but the truth." ${ }^{21}$ White Eyes' diplomacy and rhetoric had the "desired effect." The Great Council ruled that they would remain at peace with the Americans and would not rush into war against them without White Eyes as "their leader." 22

The Continental Congress assessed the situation in the west by acknowledging that the Delawares, Oneidas, Tuscaroras, and other "friendly nations," were "collecting themselves in bodies, in order to guard against the impending storm"--they were "call[ing] loudly for assistance. ${ }^{, 23}$ This assessment was accurate. The British had already struck a treaty with the western confederacy of Indian nations at Detroit. All of the confederated nations agreed to move against the Americans and, if needed, "fall upon the Delawares." The Detroit Indians gave the war hatchet to a group of young Wolf Delawares who were visiting the Great Lakes region. They were ordered by the council of western Indian nations to bring the hatchet to Goschachgunk and if they failed to do so they would be whipped. ${ }^{24}$

At this crucial juncture, the fate of the Delaware nation hinged upon what the Great Council decided regarding the support or rejection of the war proposal of the western Indian coalition. To complicate matters, by 1778, American settlers on the periphery of Fort Pitt became tired of continued efforts to secure peace with the western nations of Indians. They blamed the policies of Morgan and wanted him removed as Indian agent of the Middle Department. Many favored an American military strike against the Indians of the west,

${ }^{20}$ White Eyes to the Great Council, Goschachgunk, April 1778, in Heckewelder, Narrative of the Mission, ed., Connelley, 296.

${ }^{21}$ White Eyes in ibid., 303. The bird was the metaphor for McKee and his associates. White Eyes sent runners to the Shawnee towns on the Scioto, to warn them to pay no attention to this anti-American rhetoric. He warned, that this "flock of Birds" from the east, imposed a "Song of theirs upon us--which song had nigh proved our ruin." It can be noted that this propaganda angered the Delawares to the point that White Eyes feared for his own life. Heckewelder rushed to the Delaware capital in the middle of the night to reassure White Eyes that McKee's accusations were all false. See Heckewelder, Narrative of the Mission, ed., Connelley, 301-302, 305.

${ }^{22}$ Heckewelder in ibid., 303.

${ }^{23}$ Library of Congress, June 11, 1778, Worthington C. Ford, et al., eds., Journals of the Continental Congress, 1774-1789 vol XI, May 2-Sept. 1, 1778 (Washington, D.C.: Government Printing Office, 1908), 588.

${ }^{24}$ Zeisberger to commissioners for Indian Affairs, August 25, 1778; White Eyes to Morgan, Goschachgunk, July 19, 1778, in Morgan Letters, 3: 70, 88-89. 
assembled at Detroit. ${ }^{25}$ The Delaware nation, entrenched on the Muskingum and Tuscarawas rivers, was in danger of being caught in the crossfire in a bloody frontier war.

On the surface the three phratries were functioning as a council. Yet Captain Pipe, who mistrusted the American military after the Squaw Campaign, questioned the affinity White Eyes had with the Americans. Clearly the relationship between White Eyes and Pipe was tense and demonstrated the fragile state of Delaware unity. White Eyes gravitated to support for Americans, whom he believed recognized the neutral status of the Delawares. Pipe, on the other hand, rationalized that the Delawares could avoid destruction by not siding against the western confederation and the Six Nations. ${ }^{26}$ While Pipe and his council no longer resided near the capital seat of government at Goschachgunk, the Wolf tribe was still recognized as a vital political component of the Delaware nation.

These situations illustrated the need for a formal treaty between the Delawares and Americans. In this volatile Ohio Valley region, the Delawares feared that the western tribes would attack them when these tribes moved through the Muskingum to attack Fort Pitt. They needed a treaty that would acknowledge Delaware neutrality and at the same time, provide the Delawares with protection from both the western Indians and American frontiersmen.

Realistically White Eyes, Killbuck, and their followers favored a successful American Revolution. They believed that a victorious United States could suppress the military power and harness the aggressive stance of the Six Nations in their claims to the Ohio. Americans, on the other hand, needed the Delawares' assistance to gain access to the western stronghold of the British and their Indian allies in the Detroit region.

White Eyes, seeking a secure homeland for his people under the banner of a unified nation, believed that the time was right for the Delawares to modify their national goal of neutrality and seal an alliance with the United States. In June of 1778, he and John Killbuck informed Morgan that they believed that the "Clouds [of doubt], which arose" over the heads of the western Delawares would "soon be dispersed \& seen no more." The Great Council was

25 Savelle, George Morgan, 148-149.

26 See Wallace, ed., Travels of Heckewelder, 50-51; Heckewelder, An Account of the Indian Nations, 52-53; Thurman, "Delaware Indians in Ethnohistory," 107. 
prepared to reach an agreement with the Americans. ${ }^{27}$ This became more urgent for White Eyes, who reported one month later that the western Indian nations, who had made the treaty at Detroit, "agreed to fall on the Delawares." The Wyandots prepared to lead war excursions into Delaware country. ${ }^{28}$ American officials proposed treaty talks to commence with the Delawares in the fall of 1778 at Fort Pitt. ${ }^{29}$ A turning point in Delaware-American relations was on the horizon.

The Treaty of Fort Pitt in September of 1778 exemplified the sincerity of Delawares to live in peace in the Ohio Valley. This was the first treaty negotiated by the United States with an Indian nation. White Eyes and Killbuck of the Turtles, and Captain Pipe of the Wolf division, came to the treaty talks as the principal leaders. Representing the United States were General Lachlan McIntosh (then commandant of Fort Pitt), Colonel Daniel Brodhead, Colonel John Gibson and the Virginia representatives, Andrew and Thomas Lewis. ${ }^{30}$ White Eyes told the Americans that his people were "extremely anxious to have such an opportunity" in helping the "present [American military] Expedition against [the] common Enemy" of the Delawares. He informed the commissioners that the Delawares would "most heartily" assist them in removing the threat of the western tribes at Detroit. ${ }^{31}$

The commissioners presented White Eyes and the Delawares with a copy of the Articles of Confederation. White Eyes looked over the conditions proposed by the first government of the United States and approved its principles. He embraced the Virginia commissioners and exclaimed "brothers, we now are become one people, the Enemy Indians as soon as they hear it will strike us, we desire that our brethren will build some place for our old men, Women \&

${ }^{27}$ Message of Captain White Eyes to Morgan, Goschachgunk, June 9, 1778, in Pennsylvania Archives, first series, 5: 587-588.

${ }^{28}$ Message of Captain White Eyes to Morgan, Goschachgunk, July 19, 1778, in ibid., 5: 652.

29 Walter H. Mohr, Federal Indian Relations, 1774-1788 (Philadelphia: University of Pennsylvania Press, 1933), 72-73. The Continental Congress advised that two of the commissioners were to be from Virginia, while one commissioner would be from Pennsylvania. Virginia sent Andrew and Thomas Lewis. Pennsylvania failed to appoint a representative.

30 Treaty at Fort Pitt, September 12, 1778, in Kellogg, ed., Frontier Advance on Ohio, 138-139.

31 White Eyes to commissioners for Indian Affairs, September 12-13, 1778, in Morgan, Letter Books, 3: 95-96. 
Children to remain in safety whilst our Warriors go with you" ${ }^{32}$ He promised to send "as many of our Warriors as can possibly be spared . . . to join the assault against Detroit." ${ }^{33}$ The American army at Beaver Creek "was informed, that the Delaware Nation should be looked upon as Allies...." 34

White Eyes believed that the Delawares were united in their alliance with Americans. But he also feared the ramifications of this alliance as it was being worked out. He believed that the Delawares would be targets of the "Enemy Indians" as soon as the treaty was signed. He asked the commissioners to build forts to protect the Delaware community in the absence of the Delaware warriors as they accompanied the American military. ${ }^{35}$ White Eyes also desired that the Delaware warriors be placed under the command of American officers. ${ }^{36}$ General McIntosh, in gratitude of the support of White Eyes, gave him the title of "Lieut. Colonel of all the Indian Nations between the rivers Ohio, Mississippi \& the Lakes." 37

This treaty was a "formal alliance" which asserted peace and friendship between the United States and the Delawares. ${ }^{38}$ Representatives of the two parties continuously exchanged wampum belts--a "Belt of white Wampum with a Road \& Thirteen United States \& Delaware Nation decyphered on each side with black Wampum." ${ }^{39}$ This alliance also brought mutual responsibilities. Both parties agreed to a reciprocal support or assistance "in due proportion to

${ }^{32}$ White Eyes at Fort Pitt, Sept. 13, 1778, in Kellogg, ed., Frontier Advance on Ohio, 143.

${ }^{33}$ White Eyes at Fort Pitt, Sept. 16, 1778, in Morgan Letter Books, 3: 96-97; Kellogg, ed., Frontier Advance on Ohio, 144.

${ }^{34}$ Entry in David Zeisberger's diary, Sept. 26, 1778, in Wellenreuther, ed., Herrnhuter Indianermission, 466.

${ }^{35}$ White Eyes at Fort Pitt, Sept. 13, 1778, in Morgan Letter Books, 3: 96; Kellogg, ed., Frontier Advance on Ohio, 143. 144.

${ }^{36}$ White Eyes at Fort Pitt, Sept. 19, 1778, in Kellogg, ed., Frontier Advance on Ohio,

${ }^{37}$ From the headquarters of General McIntosh at Fort Pitt, September 21, 1778, in ibid., 433.

${ }^{38}$ Francis Paul Prucha, American Indian Treaties: The History of a Political Anomaly (Berkeley: University of California Press, 1994), 32.

${ }^{39}$ Proceedings of the Fort Pitt Treaty, September 12, 1778, in Morgan Letter Books, 3: 94, 96; Kellogg, ed., Frontier Advance on Ohio, 141. 
their abilities, till their enemies [were] brought to reasonable terms of accommodation." ${ }^{40}$ Treaty provisions acknowledged the "territorial rights" of the Delawares and promised the distribution of trade goods "from time to time, as far as the United States may have it in their power" to do so. ${ }^{41}$ Most importantly, the treaty promised the eventual establishment of an Indian state in the Ohio country. The Delawares would be the head of this Indian state and "have a representation in Congress.” Indian nations hostile to the United States were excluded from this proposed state. ${ }^{42}$ In return, Delawares would grant Americans passage through their country and guide them to the "posts, forts or towns of the enemies of the United States." They agreed to supply the American military with "corn, meat, horse, or whatever may be in their power." 43 Delawares also agreed to supply the American army with warriors, when available. ${ }^{44}$

The treaty demonstrated the confidence White Eyes and his followers had in maintaining a peaceful and harmonious existence with their American neighbors and, at the same time, gain

40 Fort Pitt Treaty, Article II, Sept. 17, 1778, in Calloway, ed., Revolution and Confederation, vol. 18 of Early American Indian Documents, 167.

${ }^{41}$ Fort Pitt Treaty, Article V, Sept. 17, 1778, in ibid., 168.

${ }^{42}$ Fort Pitt Treaty, Article VI, Sept. 17, 1778, in ibid., 169. The provisions of this article (Indian statehood) had to meet "with the approbation of Congress." Historians have been skeptical regarding the sincerity of this article. In July 1779 another Treaty of Fort Pitt was negotiated. This time, Americans made an agreement with The Raven (Coronah Savanooka), Pee Weet Bird (Shaweeskaw) and Red Parrot (Ochwalatoch)--headmen of the Cherokee nation. Much of the treaty language was similar to the Delaware Treaty. The Cherokees would join a proposed federation of tribes to form a state, "where the Delaware Nation [would] be the Head and have a representative in Congress," upon the approval of the Continental Congress. John Killbuck represented the Delawares at this treaty of alliance with the Cherokees. In September, American officials met with a Wyandot delegation and made the same proposal. The Wyandots flatly refused any cooperation or alliance with the United States. See correspondence of Colonel Daniel Brodhead to the Cherokees, the speech of The Raven, and Treaty with the Cherokees, July 22, 1779, in Kellogg, ed., Frontier Advance on Ohio, 395-400; Fort Pitt Treaty with Cherokees, Article VI, July 22, 1778, in Calloway, ed., Revolution and Confederation, vol. 18 of Early American Indian Documents, 188; Prucha, American Indian Treaties, 33.

${ }^{43}$ Edward G. Williams, Fort Pitt and the Revolution on the Western Frontier (Pittsburgh: Historical Society of Western Pennsylvania, 1978), 105-106; Fort Pitt Treaty with the Delawares, Article III, Sept. 17, 1778, in Calloway, ed., Revolution and Confederation, vol. 18 of Early American Indian Documents, 167. The full text of the treaty can also be found in Charles J. Kappler, ed., Indian Treaties, 1778-1883 (Washington, D.C.: Government Printing Office, 1904), 8.

${ }^{44}$ Fort Pitt Treaty with the Delawares, Article III, Sept. 17, 1778, in Calloway, ed.,

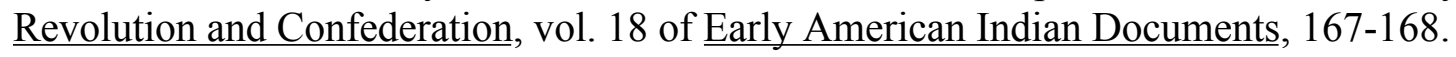


security. David Zeisberger feared that Delaware neutrality would be jeopardized if western Indian nations continued to badger the Muskingum towns. Zeisberger noted that "the Delawares flatter themselves that an [American] Army will soon come out which is their only Hope yet" to survive as a nation in the Ohio. ${ }^{45}$

The Delawares became vulnerable to the threats of western tribes. To insure this treaty there needed to be "special offers of inducements." ${ }^{46}$ Part of these incentives was the construction of forts along the Muskingum in which Delaware women and children would be protected. Article III of the treaty guaranteed "that a fort of sufficient strength and capacity be built at the expense of the said States." ${ }^{47}$ This would be accomplished in the later part of 1778, with the construction of Fort McIntosh at the mouth of the Beaver River, twenty-five miles below Fort Pitt, and Fort Laurens (a supply stockade) at the mouth of the Tuscarawas. When this task was initiated on the Tuscarawas, General McIntosh and his men were heartily received by the Delawares who threw his soldiers a feast and presented McIntosh with a "Quantity of Venison And Skins." 48

Despite the treaty and its potential to solidify positive relations between Americans and the Delawares, many factors led to disintegration in relationships. Pushed by the political visions of White Eyes for a unified Delaware nation, this treaty also illustrated the futility of maintaining an agreement with the United States, a nation concerned more with securing its independence than with matters of Indian diplomacy. While White Eyes was determined to preserve peaceful relations with the United States, the treaty was doomed to fail. Racial animosities on the frontier toward Indians, misunderstandings in treaty language, and the inability of Congress to uphold treaty stipulations rendered the treaty worthless and fractured the peace between Delawares and the United States. The failure of this treaty also revealed the chinks in Delaware consensus as pro-American and pro-British factions squared off and created a schism within the Great Council

${ }^{45}$ Zeisberger to General Hand, Goschachgunk, July 29, 1777, in Thwaites and Kellogg, eds., Frontier Defense on Ohio, 28.

${ }^{46}$ Williams, Fort Pitt and Revolution, 97.

${ }^{47}$ Fort Pitt Treaty with the Delawares, Article III, Sept. 17, 1778, in Calloway, ed., Revolution and Confederation, vol. 18 of Early American Indian Documents, 168.

${ }^{48}$ Robert McCready, "A Revolutionary Journal and Orderly Book of General Lachlan McIntosh's Expedition, 1778," edited by Edward G. Williams, The Western Pennsylvania 
and the nation itself. The unity of the phratries, delicate to begin with, became especially strained. Gradually the pro-American faction within the Lupwaaeenoawuk lost favor as the consensus tilted to the pro-British faction led by Captain Pipe.

White Eyes advocated the alliance between the Delawares and Americans on the grounds that peace could both bridge the cultural gaps between the two races and help usher the Delawares into a new era of stability and prosperity. The treaty did not change this. Delawares and Americans shared a dangerous environment in the Ohio Country, which like any frontier, bred fear and hatred between Indians and frontiersmen. In many instances these frontier animosities turned into vendettas. White settlers intruded upon Indian hunting grounds and in retribution, Indian war parties struck out at back settlements. Violence escalated when Indians whether warlike or not, wherever found, were targeted by whites in retaliatory revenge raids. ${ }^{49}$

With friendly Indians also killed indiscriminately by whites, treaties of peace could not last. The Delawares, being closest to the Fort Pitt area, always experienced much of this senseless frontier violence. In 1777, Delawares, while clinging to neutral status, complained that militia officers of Ohio and Monongahela counties were sending scouting parties into the "hunting Country" of the Delawares. George Morgan received reports that these scouting groups fired on Delaware hunters and robbed them of their pelts. ${ }^{50}$

Much of the violence stemmed from fear on both sides. David Zeisberger commented that the Delawares at Goschachgunk lived in "Consternation \& fear, expecting every day that they

Historical Magazine 43 (March 1960): 18-19. Fort Laurens was named in honor of the president of the Continental Congress, Henry Laurens.

49 James Merrell notes that on the frontier the "distance between those cultures, pushed by unhappy memories and continual friction" widened. Despite peaceful interaction on the frontier, he notes: "familiarity also bred contempt." See Merrell, Into the American Woods, 38. For excellent studies concerning the psyche, psychology, and violent tendencies of the American frontiersmen see Thomas P. Slaughter, The Whiskey Rebellion: Frontier Epilogue to the American Revolution (New York: Oxford University Press, 1986), 72-74; Roy Harvey Pearce, Savagism and Civilization: A Study of the Indian and the Idea of Civilization (Baltimore: The John Hopkins Press, 1953); Richard Slotkin, Regeneration Through Violence: The Mythology of the American Frontier, 1600-1800 (Middletown, Connecticut: Wesleyan University Press, 1973); Allan W. Eckert, That Dark and Bloody River: Chronicles of the Ohio River Valley (New York: Bantam Books, 1995).

${ }^{50}$ Morgan to Col. David Shepherd, Fort Pitt, March 31, 1777, in Morgan Letters, 1: 70, 83. 
[vigilante frontiersmen] will be upon them." ${ }^{51}$ Rumors of Indian attacks were inflated and “dilated beyond reasonable proportions." Every white person around Fort Pitt could tell a story of the relative of a friend who knew someone tortured or killed by marauding Indian war parties. ${ }^{52}$ In many cases the Delawares were blamed for the actions of British-supported Mingos and Wyandots. One year before the treaty was signed, Hand warned Delawares not to come to Fort Pitt. He told them that it would be dangerous for them to "come near to this place, owing to the foolish conduct of the Mingo's \& Wiandots" and for fear that a Delaware might be mistaken for an enemy. 53

Hand was sincere in his desire to protect the Delawares for their commitment to Americans. If friendship was extended to the Delawares, it might persuade other tribes to desert the British and ally with the Americans. Most importantly, western tribes were less of a threat to settlements on the Virginia frontier if they had to pass through pro-American Delaware country secured with American military garrisons. ${ }^{54}$

The stability of the treaty was most shaken by the death on November 10, 1778 of White Eyes, who advocated support for the United States. Two months after the treaty signing, White Eyes, who was commissioned as a lieutenant colonel in the Continental Army, was on his way to visit General Lachlan McIntosh during the construction of Fort Laurens, near current-day Bolivar, Ohio, and supposedly was "ruthlessly murdered" by "border ruffians." To prevent this incident from destroying any chance of maintaining a Delaware alliance, American officers falsely reported that the Delaware leader contracted small pox and died at Fort Pitt. ${ }^{55}$ George Morgan

${ }^{51}$ Zeisberger to General Hand, Goschachgunk, Sept. 22, 1777, in Thwaites and Kellogg, eds., Frontier Defense on Ohio, 93-95.

${ }^{52}$ Williams, Fort Pitt and Revolution, 157.

53 Hand to Delawares, Fort Pitt, Sept. 17, 1777, in Thwaites and Kellogg, eds., Frontier Defense on Ohio, 86.

54 Ruth Kathryn Theis, "The Attitudes of the White People Toward the Indians of the Upper Ohio Valley, 1749-1795" (Master's thesis, University of Pittsburgh, 1935), 69.

${ }^{55}$ Kellogg, ed., Frontier Advance on Ohio, 20-21. A great controversy surrounded the death of White Eyes. Morgan may have had an ax to grind against the United States government, who were seeking to remove him as Indian agent. White Eyes' death was revealed by Morgan to be murder, but was never proven. Morgan insisted that the murderers were militiamen. John Heckewelder, among others, maintained that White Eyes was not murdered but "took the small pox and died" while helping McIntosh construct Fort Laurens. See Heckewelder, Narrative of the Mission, ed., Connelley, 312-313. 
called White Eyes "the most trusting Indian friend the American people ever had." ${ }^{, 56}$ Morgan condemned the senseless murder of White Eyes, for he "was treacherously put to death, at the moment of his greatest exertions to serve the United States." 57 With the death of White Eyes, the pro-American element within the Great Council was sapped of its strongest advocate.

The Fort Pitt agreement was also muddled in confusion and ambiguity. Two obstacles hindered the treaty that sealed an alliance between the Delawares and the United States. First, American officials and Delaware leaders interpreted the language of the treaty differently and second, the Continental Congress was unable to honor the stipulations of the treaty. ${ }^{58}$

The foundation of the treaty was quickly pushed to the brink by the diplomatic clumsiness of General McIntosh. Less than two weeks after the murder of White Eyes, McIntosh and a poorly-equipped army met a Delaware delegation that included Killbuck, Captain Pipe, and Captain Johnny (now a Moravian convert named Israel) at a camp on the Tuscarawas River, near the construction site of Fort Laurens. McIntosh boasted that he was prepared to assault and defeat the western Indian nations at Detroit. He demanded that the Delawares provide food for his army and feed for his horses. He then reminded the Delawares that they were under treaty obligations to supply his army with warriors. ${ }^{59}$ McIntosh, hoping to impress the delegation with his power, then told them "that any nation or people who would not afterwards Join us heartily by taking up the Hatchet with us . . . Should be looked upon as

56 George Morgan in Downes, Council Fires on Ohio, 217. Also see Kellogg, ed., Frontier Advance on Ohio, 203, 217; Weslager, The Delaware Indians, 306.

${ }^{57}$ Morgan made these accusations regarding the murder of White Eyes in an unpublished letter to Congress in May of 1784. See Savelle, George Morgan, 155; Morgan's comments in Schaaf, Wampum Belts \& Peace Trees, 200.

58 At the time of the Fort Pitt Treaty, Congress was waiting for several states to ratify the Articles of Confederation. In essence, at the time of the treaty, the Continental Congress was still the de facto government of the United States. The Articles of Confederation (1781-1787) was the first constitution of the United States. The Articles government was a confederacy of sovereign states and the national government had limited power, in terms of taxation and treaty making. See Merrill Jensen, The New Nation: A History of the United States during the Confederation (New York: Knopf, 1950); Gordon S. Wood, The Creation of the American Republic, 1776-1787 (Chapel Hill: University of North Carolina Press, 1969).

${ }^{59}$ Speech of General McIntosh to Delaware delegation, Camp at Tuscarawas, Nov. 22, 1778, in Kellogg, ed., Frontier Advance on Ohio, 179-180. 
Enemys" of the United States. The Delawares looked over McIntosh's rag tag, starving army, and laughed. ${ }^{60}$

McIntosh, despite his pomposity in dealing with the Delawares, may have been correct in acknowledging their treaty obligations. However, from the very start of the treaty, the majority of the leaders in the Great Council were uncertain as to what White Eyes, Killbuck, and Captain Pipe had agreed to. Across the board, communication and clarity of the treaty was poor. George Morgan and certain Delaware leaders eventually challenged the interpretation of the treaty as fraudulent and deceptive. Morgan was absent during the treaty talks and when he returned to Fort Pitt in January of 1779 he received the complaints of the Turtle leader Killbuck, who lamented to Morgan:

Brother Taimenend ... I have looked over the Articles of the Treaty again \& find that they are wrote down false, $\&$ as I did not understand the Interpreter what he spoke I could not contradict his Interpretation. ${ }^{61}$

During the talks at Fort Pitt, the Virginians, perhaps out of ignorance rather than deception, gave John Killbuck a hatchet. Killbuck, a civil chief, expressed his disillusion to Morgan by mentioning that "I was looked upon as a Warrior, \& which was the cause of so much confusion among my People." Killbuck claimed that the "Tomahawk was handed to me at Fort Pitt but not in a Warlike manner, we all standing \& at no Council Fire, neither did I understand the meaning of it." He contended that he was not there in the capacity of a war-captain. ${ }^{62}$

Killbuck, whom Morgan had hoped would replace White Eyes as chief spokesman of the Delawares, also chimed in regarding the confusion of the treaty. He told Morgan that he was under the impression that the Delawares were to guide the American army to Detroit, not to

60 Ibid., 180; Olmstead, David Zeisberger, 286-287, 294-296. McIntosh was not only hated by the Delawares but also by the majority of the personal at Fort Pitt. See correspondence of Brodhead to Washington, Fort McIntosh, Jan. 16, 1779, in Kellogg, ed., Frontier Advance on Ohio, 200.

${ }^{61}$ Message of Captain Killbuck to Morgan, Goschachgunk, Jan. 20, 1779, in Kellogg, ed., Frontier Advance on Ohio, 202-205.

${ }^{62}$ Ibid., 202. 
fight. Killbuck also believed that White Eyes was to have served as mediator between the United States and the western Indian nations. ${ }^{63}$

Morgan was furious with the commissioners and railed that "never was a Conference with the Indians so improperly or villainously conducted." ${ }^{64}$ Morgan added that Delaware chiefs were induced to "sign certain Writings, which to them were perfectly unintelligible \& which they have since found were falsely interpreted to them." In the translations, Delawares agreed to "Declarations and Engagements they never intended to make or enter into." ${ }^{65}$ Delawares had no idea that by signing the treaty, they were taking up the war-belt as military allies of the United States in a war against the British and Western tribes. Article III specified that the United States would build forts in Delaware country. These forts were to house the women and children of Delaware warriors while they were "engaged against the common enemy" of the United States. ${ }^{66}$ This confusion certainly strengthened the argument of those Delawares who opposed an alliance with the United States. They argued that interpreters who were inadequate to the task deceived them. ${ }^{67}$ Delawares returned the war belt and hatchet to Morgan. ${ }^{68}$

This misunderstanding may be true of Killbuck and Captain Pipe. White Eyes, however, knew that this treaty sealed a military-political alliance between the Delawares and the United

${ }^{63}$ Killbuck to Morgan, Jan. 20, 1779, Goschachgunk, in Kellogg, ed., Frontier Advance on Ohio, 194, 204. There is a great deal of confusion in the testimony of Killbuck. In the Morgan Letters, $3: 151$, Killbuck is recorded by Morgan as stating the "tomahawk [was] handed to him in a Warlike manner. . ." This may be a bias on the part of Morgan who eventually roiled over this treaty. However in a letter between Colonel John Gibson to General McIntosh from Fort Laurens on February 13, 1779, Gibson contended that Killbuck had the hatchet forced upon him without proper council. According to Gibson, "it was never meant by them (United States officials) to join us as warriors, that they were only to pilot us." See Kellogg, ed., Frontier Advance on Ohio, 225.

${ }^{64}$ Morgan in Downes, Council Fires on Ohio, 216. Morgan also favored Delaware neutrality for he was a land speculator and envisioned a "neutral buffer country" between British-held Detroit and the Virginian frontier. He was preparing to speculate in land in the Illinois country. See Williams, Fort Pitt and Revolution, 97.

${ }^{65}$ Morgan to the Continental Congress, May 10, 1779, in Kellogg, ed., Frontier Advance on Ohio, 320.

${ }^{66}$ Downes, Council Fires on Ohio, 216; Williams, Fort Pitt and Revolution, 106-107;

Fort Pitt Treaty with the Delawares, Article III, Sept. 17, 1778, in Calloway, ed., Revolution and Confederation, vol. 18 of Early American Indian Documents, 167-168.

${ }^{67}$ Downes, Council Fires on Ohio, 216.

${ }^{68}$ Delawares to Morgan at Fort Pitt, May 10, 1779, in Morgan Letters, 3: 64. 
States. "Indefatigible in preserving the Nation at Peace," ${ }^{69}$ White Eyes became convinced that outside agitation from the Detroit and Sandusky regions would destroy both the neutrality and the fragile unity of the Delawares. Ever the visionary, he rationalized that Delaware independence and unity would be best served by supporting the United States and their similar political struggles. In his fervor for a strong Delaware nation residing within an Indian state, White Eyes may have deluded Killbuck and Pipe on the meaning of the treaty. Americans at Fort Pitt no doubt assisted White Eyes in this deception.

Congress recalled McIntosh from his commander's position at Fort Pitt in April of 1779 for this diplomatic duplicity. Congress insisted that the United States, as the Delaware leaders had argued, "never intended" to offer the Delawares the war hatchet. As a consequence, Delaware leaders complained to Congress that this deceit caused "great confusion" among the Delawares and "drove off two hundred" of their warriors "into the Neighbourhood of the English" at Detroit. $^{70}$

The Delawares were not ready to form a military alliance with the United States. At a time when the three phratries were struggling to maintain a national solidarity, the stress of a regional war slowly disrupted any form of cohesion within the Lupwaaeenoaw. Without the vision and guidance of White Eyes to strengthen consensus in the Great Council, the Delawares lacked the conviction to abide to a strict alliance with the United States.

General McIntosh had not been patient with Killbuck and those Delawares who did not regard the treaty as a formal alliance. He reminded Killbuck that the western tribes threatened the well being of both the Delaware nation and the United States and that it was time the Delawares assumed their responsibilities and obligations. McIntosh told Killbuck, "we became one people, it was time for all the friends of America and liberty to take up the hatchet for their own sakes

${ }^{69}$ Heckewelder, Narrative of the Mission, ed., Connelley, 312.

${ }^{70}$ Delaware leaders to the Continental Congress, May 10, 1779, in ibid., 320; Delawares to Morgan at Fort Pitt, May 10,1779, in Morgan Letters, 3: 64. Charges were brought against Fort Pitt interpreter Daniel Sullivan for "Obstructing The Commanding Officer in his duty and Transactions with the Indians." Sullivan was accused of preventing Delawares from coming to the fort during the talks, and later enticing them to break the treaty by offering them "promises and expectations of gain and furnishing them with Arguments for that purpose which would oversett all Treaties." See the charges against Daniel Sullivan, Pittsburgh, April 7, 1779, in Kellogg, ed., Frontier Advance on Ohio, 277. Sullivan was not held and one month later, he represented Delaware chiefs in Philadelphia. See Kellogg, ed.,Frontier Advance on Ohio, 302. 
with us. ..." 71 Congress informed those Delawares who insisted upon neutrality that reports confirmed that Wolf-Delawares, together with Senecas, were raiding the American frontier. Since many Delaware young men abandoned neutrality, members of Congress rationalized that they could not "expect the Assistance of such as profess to be our Friends." 72 Killbuck and Captain Johnny, on behalf of the peace faction among the Turtle and Turkey tribes, poignantly argued that there were Tories in several of the states within the United States. They pointed out: "but as that does not make those particular States your enemies ... we hope you will make a proper Distinction between our Nation and Individuals"--those individuals who were "outcasts" from the Delaware peace contingent and its friendship with Americans. ${ }^{73}$

This friendship, however, was not feasible considering the racial climate of the region. In 1780, Colonel Daniel Brodhead, Commandant of the Western Department at Fort Pitt, recruited a band of forty Delaware warriors to fight pro-British Indians. These warriors camped with their families outside Fort Pitt. Brodhead had to assign a "guard of regulars" to protect these Delawares when a group of whites from Hannastown "attempted to destroy them, women and children as well as men." 74 A private in the 13th Virginia Regiment savagely murdered one young Delaware, "one of the best young men of the Delaware nation." Brodhead complained to General Washington that Delawares were targets and mentioned that a delegation of Delaware chiefs, on their way to Philadelphia to address Congress, were in serious jeopardy, for "several parties" had gathered to murder the delegation. Brodhead feared a general Indian war as the result of the barbarity of these frontiersmen. ${ }^{75}$ Congress naively advised all Delawares who were friendly to the United States to leave their towns on the Muskingum and to settle near Fort Pitt for their own protection. Delawares were conditioned by history to reject this well-intentioned

${ }^{71}$ McIntosh to Killbuck, Fort Pitt, Feb. 13, 1779, in Kellogg, ed., Frontier Advance on Ohio, 236.

72 Speech of the Continental Congress to a Delaware delegation, Philadelphia, May 26, 1779, in ibid., 341-342.

${ }^{73}$ Reply of Delawares to Continental Congress, Philadelphia, May 26, 1779, in ibid., 352. In this document, Killbuck (Gelelemend) was listed as "1st Chief," Captain Johnny or Israel was listed as " $2 \mathrm{~d}$ Chief."

74 Louise Phelps Kellogg, ed., Frontier Retreat on the Upper Ohio, 1779-1781 (Madison: Publications of the State Historical Society of Wisconsin, 1917), 290. Also see Wallace, Death and Rebirth of the Seneca, 146-148. 
invitation. They remembered the massacre of Conestoga Indians at Lancaster in 1763 at the hands of the Paxton boys and the "narrow escape of the Christian Indians in the City of Philadelphia" from the same fate. In both instances, these Indians were supposedly under the protection of whites. $^{76}$

The main contributor, however, in the destruction of Delaware and American relations was the inability of a fiscally strapped Continental Congress to meet its treaty obligations. As early as 1777 , Delawares questioned the ability of the Americans to supply trade goods to the Indian towns on the Muskingum. Captain Pipe had complained to Morgan that the Delawares were being ridiculed by the western tribes for "being attached" to Americans "who cannot even furnish us with a pair of Stockings or a Blanket. ..." 77 Article V of the Fort Pitt Treaty guaranteed "clothing, utensils and implements of war" to be distributed when possible by the United States. ${ }^{78}$ The Delawares were deeply concerned when trade goods did not reach them. Killbuck asked for "traders ... with goods as our women \& Children are poor \& naked $\&$ in danger of perishing." Colonel Brodhead at Fort Pitt sympathized with Killbuck, but contended that the deep snow had prevented "getting supplies over the mountains for the Delawares." 79 Brodhead acknowledged that peace with the Delawares was predicated upon the ability of Congress to supply them with trade goods. ${ }^{80}$

A Delaware national delegation headed by Killbuck and Captain Johnny visited Morgan's home at Princeton, New Jersey, and with his help drafted a petition to be addressed to General George Washington and the Continental Congress in May of 1779. The chiefs maintained that their friendship with the United States depended on the reality that they could observe "strict neutrality between the United States and Britain." The chiefs reminded Congress that the treaty

${ }^{75}$ Colonel Brodhead to General Washington, Fort Pitt, May 3, 1779, in Kellogg, ed., Frontier Advance on Ohio, 306-307.

${ }^{76}$ Heckewelder, Narrative of the Mission, ed., Connelley, 265. Regarding the Paxtons and their racial vigilantism against the Conestogas see J. A. Leo Lemay, ed., Benjamin Franklin: Writings (New York: The Library of America, 1987), 540-556.

${ }_{78}^{77}$ Captain Pipe to Morgan at Fort Pitt, in Morgan Letters, 1: 80.

${ }^{78}$ Fort Pitt Treaty with the Delawares, Article V, Sept. 17, 1778, in Calloway, ed., Revolution and Confederation, vol. 18 of Early American Indian Documents, 168.

${ }^{79}$ Brodhead to Killbuck, Fort Pitt, Feb. 17, 1780, in Kellogg, ed., Frontier Retreat on Ohio, 139.

${ }^{80}$ Ibid., 181. 
promised goods, in exchange for the fur pelts and deer hides of their hunters. ${ }^{81}$ The delegation asserted that traders were not entering Delaware country--a provision "absolutely necessary for the Subsistance of their Women and Children." Through the three previous treaties made with Anglo-Americans at Fort Pitt, provisions of goods had not been "complied with in any degree." These treaties were signed in good faith but left the "Delaware Nation ... poor and naked" and reduced them to send their leaders in person to "Congress \& to his Excellency General Washington" and plead their case. ${ }^{82}$ They asked Congress to live up to their treaty obligations; otherwise, the Delawares would have to "look to the English alone for the supplies of all their Wants." 83

The pro-American delegation of Turtle and Turkey Delawares did not want to sever ties with the United States. Killbuck and Captain Johnny promised that they would embrace the white man's civilization and "become one Peopl[e] with our Brethren of the United States," while nurturing a friendly relationship "to the end of time." ${ }^{84}$ Delaware leaders wanted Congress to provide and pay for the schooling of their children. They also urged for congress to send a "useful Tradesmen and Husbandmen" to live with the Delawares and "instruct the Youth" in the professions. They agreed to increase the number of their men to be sent east and educated at Princeton and to permit school teachers to enter Delaware country and to instruct their young men in the vocation of a skilled trade or to demonstrate new agricultural methods. ${ }^{85}$ With

${ }^{81}$ Morgan's speech on behalf of Delaware chiefs to the Continental Congress, May 10, 1779, in Kellogg, ed., Frontier Advance on Ohio, 325. Morgan condemned the deceptions of McIntosh and others on his staff during the Fort Pitt Treaty proceedings and feared that a "general Indian War" was on the horizon as a result of this deception. He resigned his position as Agent for Indian Affairs on May 28, 1779. See the resignation of Morgan in Kellogg, ed., Frontier Advance on Ohio, 345.

${ }^{82}$ Ibid., 325-326.

83 Ibid., 318.

84 Ibid., 319.

85 Ibid., 319. White Eyes had sent his eight-year-old son and Killbuck sent two of his sons to be schooled at Princeton. George White Eyes won academic awards as a boy, but when he reached college, he quit school to return to his people. He became an alcoholic and was killed by a white man when he was involved in a drunken brawl on Beaver Creek in Western Pennsylvania in 1798. Thomas Killbuck, the half-brother of Killbuck's other son John, studied geography and Latin, but became homesick and returned home. John Killbuck, Jr. had an affair with one of George Morgan's maids. From this relationship they had a child and John left 
diplomatic dexterity, Killbuck used the example of Moravian Delaware converts to apply leverage in their demands to Congress. The chiefs pointed out that the Moravians had "established a Town where numbers of [their people] have embraced Christianity under the Instruction of the Reverend and worthy David Zeisberger." The Delaware peace faction believed that the Moravian missions had exerted tremendous influence regarding the "love of Peace into the Minds of the whole Nation." 86

Washington was direct in his reply by telling the Delaware delegation, "I am a warrior" and that it was his "business to destroy all the Enemies of these States and to protect their friends. ${ }^{" 87}$ Washington informed the Delawares of the great carnage exacted by his army on the Onondaga, in retaliation for the wrongs committed by the Six Nations against the United States. He sympathized with the plight of the Delaware people and condemned those who had "not dealt justly" in regard to the treaty. He apologized by telling them "there are some matters about which I do not open my lips, because they belong to Congress and not to us warriors. You are going to them. They will tell you all you wish to know." 88

Congress replied to the complaints of the Delaware leaders by reminding them that the "Great Councel of the United States" had always strove for justice and "benevolent wishes" towards their Delaware brethren, as exemplified by the previous treaty talks at Fort Pitt in 1775, 1776, and 1777. They did not consider the current treaty as finalized. ${ }^{89}$ Congress stated that it "was out of [their] power to do all that [they] wished for [their] Indian Brethren." Congress

Princeton to support them. John Killbuck, Jr. became a chief in 1811, after the death of his father. See Kellogg, ed., Frontier Advance on Ohio, 319.

${ }^{86}$ Ibid., 320 .

${ }^{87}$ Washington to Delaware chiefs, May 12, 1779, in John Rhodehamel ed., George Washington: Writings (New York: The Library of America, 1997), 350.

${ }^{88}$ Ibid., 351. Throughout 1778 and 1779, combined forces of British loyalists and four tribes of the Iroquois Confederacy, the Senecas, Mohawks, Onondagas and Cayugas, ravaged the Cherry Valley communities of Upper New York state. Alarmed at the success of the Tory-Indian raids, Continental Army commander George Washington organized a three-pronged invasion of Iroquois country with instructions to his commanders that Indian towns must not "merely be overrun but destroyed." These military strikes started in the spring of 1779 against the Onondagas and continued throughout the summer. See Carl Waldman, Atlas of the North American Indian (New York: Facts on File Publications, 1985), 111-112; Wallace, Death and Rebirth of Seneca, 141-148.

${ }^{89}$ The Continental Congress to Delaware chiefs, May 26, 1779, in Kellogg, ed., Frontier Advance on Ohio, 340-341. 
maintained that the British, through their plundering of American shipping, were to blame for the shortage of trade goods. ${ }^{90}$

Congress criticized the Delaware chiefs for their insistence on remaining neutral rather than allying with the United States. Congressional officials insisted, "you cannot be surprised that our Warriors ask for, \& expect the Assistance of such as profess to be our Friends." They also condemned the actions of the Munsee-Wolf Delawares who had "joined the Senecas and taken up the hatchet" against Americans. ${ }^{91}$ David Zeisberger believed that these MunseeDelaware warriors tried to "get their friends away from the church, and to control them" when they urged mission Delawares to join them in their raids against Pennsylvania and Virginia. ${ }^{92}$

Zeisberger previously had been most adamant in his condemnation of the Munsee-Wolf warriors who continually breached the peace between Goschachgunk and Fort Pitt. He thought that Captain Pipe and his militant supporters should be forever "cast out of the Council" and put under the stringent control of the Turtle-Turkey civil leaders. He saw the Wolf tribe as being drawn to the confederation of Indian nations at Detroit. Zeisberger concluded that to save the nation, dissent of the Wolf war faction needed squelched. ${ }^{93}$

The Moravians were no doubt biased in their assessment of Captain Pipe and his councilors. Pipe wanted to banish all missionaries from Delaware country. He saw the Moravians as obstacles in his plan to bring the Delawares within the council fires of the western Indian nations. He condemned Moravian-influenced pacifism as detrimental to the development of a strong Delaware nation. ${ }^{94}$ Unlike White Eyes, who envisioned strength through diplomacy, Pipe believed that only a militarily strong Delaware nation, linked in a confederation of Indian nations,

90 Ibid., 341.

91 Ibid., 341-342.

92 Zeisberger in Bliss, ed., Diary of David Zeisberger, 2: 27.

93 Zeisberger, from Goschachgunk to commissioners at Fort Pitt, August 25, 1778, in ibid., 132-133.

${ }^{94}$ Loskiel, History of the Mission, 2: 86-87;

Gray, Wilderness Christians, 54-55. See Wallace, ed., Travels of Heckewelder, 432; Sipe, Indian Chiefs of Pennsylvania, 420-421; Barbara Alice Mann, “I Hope You Will Not Destroy What I Have Saved': Hopocan before the British Tribunal in Detroit, 1781," in Barbara Alice Mann, ed., Native American Speakers of the Eastern Woodlands: Selected Speeches and Critical Analyses (Westport, Connecticut: Greenwood Press, 2001), 145. 
could save them from the being dislocated once again by Anglo or American territorial encroachments.

In the Great Council House, the three phratries "had frequent and violent disputes, concerning the ... fate of the Indian congregation." Unlike his uncle, the prominent Wolf leader Custaloga who first invited the Moravians to Delaware country, Pipe and many of his followers opposed the establishment of the Moravian mission towns. ${ }^{95}$ In the Delaware council, Pipe's overtures for a war against the Americans were continually blocked by White Eyes, Killbuck, Captain Johnny and the Moravians, Zeisberger and Heckewelder, both of whom had great influence "on matters necessary for the preservation of peace" among the Delaware civil chiefs. ${ }^{96}$

After the death of White Eyes, the peace faction lost footing and momentum in the Great Council. Captain Pipe, a skeptical signer of the Fort Pitt Treaty, commenced negotiations with the British. Pipe, "with an air of prophecy," considered the death of White Eyes an act from the Great Power to save the Delaware nation from an alliance with the United States. ${ }^{97} \mathrm{He}$ had condemned the pro-American bias of White Eyes and had always threatened to isolate him politically from the mainstream. Pipe, described by Heckewelder as bold, frank, and sagacious, once addressed the Great Council at Goschachgunk in the presence of White Eyes and told them that he would "declare every man an enemy to the [Delaware] nation" who would not take arms against the Americans. ${ }^{98}$ Pipe and bands of the Wolf tribe trickled out of the Upper Sandusky region into Detroit to join the Ottawas, Chippewas, Shawnees, and Mingos. Pipe used diplomatic skill and oratorical prowess to convince the Great Council to turn its back on the pacifist United Brethren and the Americans at Fort Pitt and to join the western Indian alliance. He gained influence with the "hungry and disillusioned" Delawares. The British, offering supplies and arms, lured an increasing number of Delaware warriors into "their orbit." 99

95 Loskiel, History of the Mission, 3: 197.

96 Heckewelder, April 1778, at Goschachgunk in Booth, ed., Tuscarawas Valley in Indian Days, 187; Gray, Wilderness Christians, 54-55.

97 Heckewelder in Wallace, ed., Travels of Heckewelder, 152.

98 Heckewelder, April 1778, at Goschachgunk in Booth, ed., Tuscarawas Valley in Indian Days, 188; Heckewelder, An Account of The Indian Nations, 135-136; Heckewelder, Narrative of the Mission, ed., Connelley, 296.

${ }^{99}$ Calloway, American Revolution in Indian Country, 37; Weslager, The Delaware Indian Migration, 40-41. 
In the fall of 1780, Heckewelder sent word to Brodhead at Fort Pitt that Delaware councils, won over by Captain Pipe, had decided to launch attacks on the American frontier. ${ }^{100}$ The Delawares experienced a great "political division" between the supporters of Killbuck and the supporters of Captain Pipe. The pro-American Delaware leaders at Goschachgunk lost control of many of the young warriors who were exasperated at the influence held by the Americans and Moravians over Killbuck and the others. ${ }^{101}$ The "political division" caused by Pipe increased and made it difficult for the "Peace Chiefs" at Goschachgunk to "preserve the Nation at peace. ..." 102 The peacemakers among the Delawares, such as Killbuck and Tetapachksit of the Turtles, and the Turkey leader known as The Big Cat (Machingwi Puschis), were shouted down at the Delaware council fire. Pipe and his supporters opposed Turtle-Turkey leaders who were "wishing to see the Nation become a civilized and agricultural people." Pipe believed that this harmful direction could best be countered by bringing the Delawares into the coalition of western Indian nations. This would also remove the Delawares from the influences of the Moravians and the Americans at Fort Pitt. ${ }^{103}$

Most importantly, the civil leaders of the Turtle and Turkey tribes could no longer uphold the peace. Civil chiefs, in times of war, had little power and lacked "coercive prerogatives" in the councils. With military tensions increasing in the Ohio and the demise of the Turtle-Turkey peace factions at the Delaware council fire, militant headmen such as Captain Pipe, the Wolf war captain known as Buckongahelas ("One Whose Movements Are Certain"), and the prominent Turtle war captain Wingenund took advantage of this political capital and pressed their agendas of war. These warriors and their followers gained preeminence and dominated the Lupwaaeenoawuk. ${ }^{104}$ They won over the sentiment of the Great Council and

${ }^{100}$ Downes, Council Fires on Ohio, 265.

${ }^{101}$ Heckewelder, Narrative of the Mission, ed., Connelley, 251, 327.

102 Ibid., 327.

103 Ibid., 325-329, 455.

104 Goddard, "Delaware," in Trigger, ed., Handbook of North American Indians, 216. Also see Heckewelder's comments in Booth, ed., Tuscarawas Valley in Indian Days, xxv, 49, on the functioning of Delaware government in time of war. The duty of the principal civil chief was to maintain the "peace and covenants made between his people and the other Indian nations and the Europeans." He was to keep cohesion and order, but to do so with "calm reasoning and friendly exhortion." Civil chiefs strove for and maintained peace when it was possible. In times of war, civil chiefs were subservient to war-captains. See Weslager, The Delaware Indian Migration, 
hijacked the course of the Delaware nation. The Great Council became centralized as the political engine of the Delaware nation, and at the same time the council, in its pursuit of a national consensus, wracked the nation with factionalism. At the time it seemed that the Delaware military leaders represented a strong alternative to the failed policies of the Turtle-Turkey peace faction. The shift from the civil to a war standing had a great impact on the future development of the Delaware nation.

In the long run, it was Moravianism that dealt the deathblow to the pro-American contingent of Delaware chiefs. Killbuck increasingly lost influence in the Lupwaaeenoawuk after the death of White Eyes. ${ }^{105}$ He complained that the Great Council kept him in the dark on most affairs, "so that [he] knew nothing." 106 Killbuck did not have the charisma and vision of White Eyes, and despite his courage, lacked the stomach and fortitude for a power play within the council. He also did not have the motivation to challenge Pipe for political supremacy. ${ }^{107}$

Killbuck and his pro-American supporters were reduced to the "lamentable Situation of Refugees." 108 He at that time was undergoing a spiritual transformation. Killbuck, greatly influenced by Heckewelder and the Moravians, became a Christian and resigned from the Delaware council in early 1781. He told Colonel Brodhead, who was adopted by Killbuck's tribe, "You are a Turtle Yourself, \& there are many Men in our Tribe, Therefore You will not be at a loss to find one good one, who will speak the truth." 109

Two other peace chiefs who leaned to the Americans also converted to Moravianism. Captain Johnny resigned from the council to live among the mission Indians at Lichtenau in 1777. Another pro-American leader, the aged Echpalawehund, became a Christian and was baptized as

292. See Zeisberger in Hulbert and Schwarze, eds., “Zeisberger's History,” 99. In numerous documents, Buckongahelas was also referred to as Pachgantschihilas.

105 Sipe, Indian Chiefs of Pennsylvania, 419; Wallace, ed., Travels of Heckewelder, 419.

106 Killbuck, from the mission town of Salem to Brodhead at Fort Pitt, February 26, 1781, in Kellogg, ed., Frontier Retreat on Ohio, 339.

107 Killbuck, from the mission town of Salem to Brodhead at Fort Pitt, January 15, 1781, in ibid., 317.

108 Correspondence of George Morgan to Congress, Princeton, May 12, 1784, in Booth, ed., Tuscarawas Valley in Indian Days, 273.

${ }^{109}$ Killbuck, from the mission town of Salem to Brodhead at Fort Pitt, January 15, 1781, in Kellogg, ed., Frontier Retreat on Ohio, 317. 
Petrus. He was permitted to sit in the Great Council, and up until the political ascension of the Wolf tribe, he still maintained a degree of political influence in the council. ${ }^{110}$

The conversion of these leaders presented Moravians with a dilemma. They needed these men to remain as influential members of the council. This would permit the missionaries to "recruit more converts and repress their critics." ${ }^{111}$ Without the support of the civil leaders, the missionaries' power waned, as did support for peace with the Americans. In an ironic sense, it was against the interests of the Moravians to convert influential civil leaders, who in turn, might decide to leave the Great Council to practice their Christian beliefs in the mission towns. Conversion to Christianity also weakened the peace faction of Delawares at a time in which they needed conviction and the strength of numbers to resist the calls for war.

Unfortunately the Moravians built their missions in a region that "was fast becoming a war zone." ${ }^{112}$ Indian war parties from the west entered the mission towns and coerced converts into supplying them with food and a place to rest. The demands of the warriors "was a very disagreeable business for the inhabitants of Lichtenau," who were themselves hungry. ${ }^{113}$ Zeisberger lamented to a companion: "how could we live in the midst of warriors ... We should be swallowed and devoured." 114 The steady appearance of western warriors in Delaware towns along the Muskingum caused disruption and further weakened the peace. ${ }^{115}$

Moravians, despite their anti-military views, tended to favor the Americans and clandestinely aided the American cause. Heckewelder relayed messages pertaining to the British at Detroit and the movement of western warriors to military officials at Fort Pitt. Messages were put in the "folds of the saddle blanket beneath the saddle" and delivered by Delaware messengers. Moravians constantly sent runners to Fort Pitt with military information. ${ }^{116}$

${ }^{110}$ Wallace, ed., Travels of Heckewelder, 198, 407, 427; Weslager, The Delaware Indians, 288.

${ }^{111}$ Schaaf, Wampum Belts \& Peace Trees, 85.

112 Calloway, New Worlds For All, 81.

113 Heckewelder, Narrative of the Mission, ed., Connelley, 162.

${ }^{114}$ Ibid., 242.

115 Ibid., viii.

${ }^{116}$ Eckert, That Dark and Bloody River, 190. Also see Joseph Doddridge, Notes on the Settlement and Indian Wars of the Western Parts of Virginia and Pennsylvania From 1763-1783, (1912; reprint, Bowie, Maryland: Heritage Books, Inc., 1983), 196-197. The Moravian Church of America was located in Bethlehem, Pennsylvania and supplied the Ohio missions with financial 
Realistically, it was not in the best interest of the Delawares to align with an American nation that was financially unstable. Many Delawares slowly gravitated to the British, particularly when the Americans failed to honor the Fort Pitt Treaty stipulations and were seen as untrustworthy. Heckewelder notified Colonel Brodhead at Fort Pitt that the Delaware council was leaning toward the British, and the war captains were attempting to "blacken the Character of Killbuck" for his friendly leanings towards the Americans. ${ }^{117}$ In March of 1781 Brodhead received word from a friendly Delaware that the Great Council "ha[d] declare'd in favor of the British" and Delaware warriors had commenced in raids on American settlements. ${ }^{118}$

To demonstrate his friendship, Killbuck threw in his full support for the United States. Killbuck was not a pacifist, despite his newfound Christianity and his earlier stance, in which he opposed a military alliance with the United States. Like Heckewelder, Killbuck desired to purge the Delaware of the warriors who disrupted the Muskingum Christian towns. In the spring of 1781, commissioned as Colonel William Henry Killbuck, he led eighty Delaware auxiliaries against the Indian alliance at Detroit. Killbuck was also prepared to fight Captain Pipe, his Wolf followers, and the Unami Delawares who had taken control of the capital at Goschachgunk. Heckewelder offered Brodhead's command a safe haven if they should march through the Moravian Delaware towns to "punish [those] wicked people" at Goschachgunk. ${ }^{119}$ Brodhead, with over three hundred Continental Army troops, militia, and his Delaware allies, led a preemptive strike against the Delawares at Goschachgunk on April 19, 1781. There they found fifteen Delawares who were hostile to the United States. They were tried by a military tribunal, sentenced to death, tomahawked, and scalped. Killbuck and his warriors discovered a party of over forty Delawares on the banks of the Muskingum who were performing a victory dance--in honor of their great success against American settlements. He and his warriors attacked the Delawares. Killbuck chased the war captain, killed, and then scalped him. ${ }^{120}$ Brodhead leveled

support. Thus Zeisberger felt more connected to America than to Great Britain. See Olmstead, Blackcoats Among the Delaware, 28.

${ }^{117}$ Heckewelder to Brodhead, February 26, 1781, in Kellogg, ed., Frontier Retreat on Ohio, 337-339.

${ }_{118}$ Brodhead to Colonel David Shepherd, Fort Pitt, March 8, 1781, in ibid., 342.

${ }^{119}$ Heckewelder to Brodhead, Salem, Feb. 26, 1781, in ibid., 337-338.

${ }^{120}$ Pennsylvania Archives, first series, 1: 770; Weslager, The Delaware Indians, 313-

314. Killbuck was baptized in 1789 as William Henry Killbuck in honor of Major William Henry 
Goschachgunk and moved northward to torch the Moravian mission town of Lichtenau. The victorious Americans captured prisoners and took cattle and furs, which were sold at Wheeling. The Moravian missionaries and Delaware Christians were not harmed. ${ }^{121}$ Brodhead's preemptive strike into Delaware country broke the reluctance of the Great Council to become active allies of the British. His destruction of the Delaware capital, Goschhachgunk, now a stronghold for warriors hostile to the United States, was the final straw. ${ }^{122}$

Brodhead correctly assessed the situation by telling Washington that if supplies were not sent, the pro-American Delawares would be "compelled to make terms with the British or perish." ${ }^{123}$ The Delawares became allies of the British not out of sentiment or sense of attachment, but because of the "default of the Americans," and their failure to provide the trade goods which would have been seen as a token of support. ${ }^{124}$ As the Revolutionary War slowly shifted in favor of the Americans, it turned into a disaster for the Delawares. The Wolf division, as the most militant and pro-British element, became the dominant division.

While Pipe opposed American intrusions in Delaware country, he was not a client chief of the British. He would not support the British if it meant the destruction of the Delaware nation. In November of 1781, one month after Lord Cornwallis's surrender to American and French forces at Yorktown, Virginia, Pipe attempted to mediate the Delaware stance. In council at Detroit, Pipe lashed out at the British Colonel Arent Schuyler De Peyster for pressuring

of Lancaster County. Henry was a Moravian who saved Killbuck's life during the Seven Years' War. See Olmstead, Blackcoats Among the Delaware, 77, 95, 222. For his part in aiding Brodhead, Killbuck, his warriors, and their families, went into exile. Many were relocated around Fort Pitt and given protection by the American military; others were given sanction on an island (known as Killbuck's Island) near the junction of the Allegheny and Monongahela rivers. Vigilantes attacked Killbuck and his family. They swam the river and gained protection at Fort Pitt. The vigilantes destroyed Killbuck's home, including wampum belts and valuable documents that William Penn had given to the Delawares. See Heckewelder, Narrative of the Mission, ed., Connelley, 264; Sipe, Indian Chiefs of Pennsylvania, 419.

${ }^{121}$ Downes, Council Fires on Ohio, 265.

122 Ibid, 265; White, The Middle Ground, 388-389; Booth, ed., Tuscarawas Valley in Indian Days, 197-198.

${ }^{123}$ Brodhead to Washington, Fort Pitt, September 16, 1780, in Kellogg, ed., Frontier Retreat on Ohio, 172.

${ }^{124}$ Weslager, The Delaware Indians, 313 . The failure to honor the treaty obligations was a harbinger for future treaties between the United States and Indian tribal nations. The Treaty of 
Delawares to fight in a war that did not concern his people, and thus disrupting the peace he had hoped to attain for his nation. Brandishing a stick with a scalp attached, Pipe scolded the commander by reminding him:

You may perhaps think me a fool, in risking my life at your call: and in a cause too, by which I have no prospect of gaining anything; for it is your cause, and not mine to fight the Long Knives. You both have raised the quarrel within yourselves; and by right, you ought to fight it out yourselves and not compel Your Children [the Delawares] to expose themselves to Danger for Your sake . . . Father! Many lives have already been lost on your account! Nations have suffered and been weakened! Children have lost Parents, brothers, and relatives! Wifes have lost Husbands! .. . The Warrior [Delaware nation] is poor and his cabin is always empty; but your house, father! is always full. ${ }^{125}$

Captain Pipe told De Peyster that his people were reluctant to go to war "against a People who had done [them] no injury." He defended his decision to raid the American frontiers with the Senecas--for if he failed to support the British he believed that they would withhold trade goods from the Delawares. Pipe also knew that the two sides were preparing to initiate peace talks. He feared that the Delawares had "expose[d] themselves to Danger" for the sake of the British, who were "shaking hands with the Long Knives." 126

The decision of the Lupwaaeenoawuk for the Delawares to ally themselves with the British in 1781 had isolated the Moravian Delawares and sandwiched them between the hostile western tribes and the white frontiersmen around Fort Pitt. On the Muskingum, warriors made raids and brought their captives to the missionary town of Gnadenhutten. When this region

Fort Pitt set the precedent for future failures of Americans and Indians to live up to treaty obligations.

${ }^{125}$ Speech of Captain Pipe to De Peyster, November 1781, in James H. O'Donnell, ed., “Captain Pipe's Speech: A Commentary on the Delaware Experience, 1775-1781," Northwest Ohio Quarterly 64 (1992): 126-133. Last sentence of speech can be attributed to Heckewelder, An Account of the Indian Nations, 136; Wallace, ed., Travels of Heckewelder, 405. 
"became a theatre of war," De Peyster and the British at Detroit provoked Indian war-captains to remove the Christian Indians from the Muskingum. ${ }^{127}$ Captain Pipe, who "had sworn destruction to the Brethren," instigated Wolf warriors and their Wyandot allies to attack the Moravian towns. In return, he promised that the warriors could possess the "whole booty gained on the Muskingum." 128

The British feared that the Moravian missionaries retained an incredible influence and could sway the Great Council back into supporting the United States. To sever the ties, the British ordered that the Moravian missionaries be seized and brought to Detroit to be tried by a military tribunal on the charges of aiding the American rebels. ${ }^{129}$ In the spring of 1781, the Wolf war captain Buckongahelas and his warriors entered the mission town at Gnadenhutten to capture the newly-converted Killbuck and to persuade the Christian Delawares there that the American Revolution was a family war in which the "Father was in the right; and that his Children deserved to be punished a little!" ${ }^{130}$ Buckongahelas warned the Delawares at Gnadenhutten that they lived in a dangerous region and should be wary of the "footsteps of the Long Knives [Virginia militia], almost within sight" of the Muskingum. He pleaded with them to remove to a safer place, out of the path of the "contending parties" of British and Americans. ${ }^{131}$ The Christians thanked him for his concern but declined to move, as they "found no cause to mistrust the sincerity of their American Brethren!" 132

On August 10, 1781, a large group of Wyandots, loyalists, British soldiers, together with Captain Pipe, Wingenund, and a group of Delaware warriors from the Upper Sandusky and Detroit regions entered Salem and then Gnadenhutten in a "Warlike Manner on Horseback, one

${ }^{126}$ Captain Pipe, Detroit, November 1781, in O’Donnell, ed., "Captain Pipe's Speech,” 132-133.

${ }^{127}$ Zeisberger in Bliss, ed., Diary of David Zeisberger, 1: 7. Also see Williams, Fort Pitt and Revolution, 156-157.

${ }^{128}$ Loskiel in History of the Mission, 3: 197; Gray, Wilderness Christians, 54-55.

${ }^{129}$ Heckewelder, Narrative of the Mission, ed., Connelley, 275.

${ }^{130}$ Ibid., 337. Killbuck had already gained asylum among the Americans and at that time was living on an island outside of Fort Pitt.

${ }^{131}$ Ibid., 338.

${ }^{132}$ Ibid., 339. 
Man bearing an English flag. ..." to coerce the converts to move from the Muskingum. ${ }^{133}$ As they moved north through the Muskingum, the warriors became belligerent toward the missionaries. They plundered Heckewelder's home and stripped Zeisberger and other missionaries of their clothing and gave them old rags and linen to wear. ${ }^{134}$ At Schoenbrunn, the war party took Zeisberger's wife as a prisoner. ${ }^{135}$

Moravians, both white and Indian, watched the Wyandots plunder Schoenbrunn. The Wyandots ransacked the church and took "communion utensils." ${ }^{136}$ But bonds were strong among the Delawares. When the party reached the Sandusky location called Captives Town, some of the Munsees became displeased at the bad treatment of both Delaware and white Christians. Zeisberger, who had been adopted by the Wolf tribe, noted that these Munsees had "shown themselves good to us, and had done us no harm; they often showed their discontent with the conduct of the Wyandots towards us." 137

Zeisberger and his brethren spent over fifteen months at Captives Town. On October 31, 1781, De Peyster summoned Zeisberger, Heckewelder, and other Moravian missionaries to Detroit to face charges of treason against the Crown for supplying information to Americans at Fort Pitt. De Peyster eventually relented, through the intervention of Captain Pipe, and released the missionaries, who returned to Captives Town. ${ }^{138}$

The Sandusky Indians at Captives Town underwent drought and shortage of game. ${ }^{139}$ One Delaware war captain who was bitter towards the converts sarcastically observed: "These are the People who lived so well a while ago . . . Now they have nothing, \& creep about looking

133 Ibid., 349, 359; Heckewelder in Wallace, ed., Travels of Heckewelder, 170-171; The Wyandot Half-King known as Pomoacan ("Sweet House") was with the Upper Sandusky group. In his oratory, he ordered the Moravian community to leave the Muskingum. For Pomoacan's speech to the Moravian Delawares see Booth, ed., Tuscarawas Valley in Indian Days, 199-200.

134 Zeisberger in Bliss, ed., Diary of David Zeisberger, 1:13.

135 Ibid., 1:12.

136 Ibid., 1:13.

137 Ibid., 1:10.

138 Olmstead, Blackcoats Among the Delaware, 37-46; Mann, "“I Hope You Will Not Destroy What I Have Saved" in Mann, ed., Native American Speakers, 152-157. In a change of heart, Pipe became steadfast friends with Zeisberger and Heckewelder. He defended them against the charges of the British tribunal.

139 Heckewelder, Narrative of the Mission, ed., Connelley, 390. 
for Food, as we are used to do." 140 A large group of starving Moravian Delawares returned to their Muskingum homes in the late winter of 1782 to gather corn in the fields they had left behind. ${ }^{141}$ The converts returned to Salem and Gnadenhutton "without any Manner of Fear \& Uneasiness" of impending danger as war waged on the Ohio frontier. ${ }^{142}$

In March of 1782, Colonel David Williamson and 160 Pennsylvania militiamen from Washington County, in search of a Wyandot war party, entered Gnadenhutten. Williamson falsely accused the Christian Delawares of the raids along the Ohio River that had been perpetrated by the Wyandots. The peaceful Delawares were disarmed and massacred by the militia for crimes they did not commit. ${ }^{143}$ Only four of ninety-four Delawares escaped the slaughter. ${ }^{144}$ Three prominent Delaware leaders who had converted to Christianity--Glikhikan, the once-feared Wolf war captain, now known as Isaac, Echpalawehund, who became Petrus, and Captain Johnny, who was Christianized as Israel, were among the victims. ${ }^{145}$

${ }^{140}$ Heckewelder in Wallace, ed., Travels of Heckewelder, 188.

141 R. Douglas Hurt, The Ohio Frontier: Crucible of the Old Northwest, 1720-1830 (Bloomington: Indiana University Press, 1996), 90-91; White, The Middle Ground, 389-390; Booth, ed., Tuscarawas Valley in Indian Days, 207-208.

142 Heckewelder in Wallace, ed., Travels of Heckewelder, 189.

143 Ibid., 189. General William Irvine, the commander of Fort Pitt, later disclosed the following tragedy to his wife of the merciless carnage that had transpired at Gnadenhutten when the militia bludgeoned their victims with cooper's mallets and tomahawks and "did not spare either age or sex. What was more extraordinary they did it in cold blood [and] they fell on, [the Christian Indians] while they were singing Hymns, and killed the whole. Many children were killed in their wretched Mother's arms." General Irvine to wife on April 12, 1782, in Mary C. Darlington, ed., Fort Pitt and Letters From the Frontier (1892; reprint, New York: Arno Press, Inc., 1971), 238-239. For more narrative on this massacre see Heckewelder, Narrative of the Mission, ed., Connelley, 422-429; Slaughter, The Whiskey Rebellion, 75-78; Eckert, That Dark and Bloody River, 313-323; Weslager, The Delaware Indian Migration, 45-46.

${ }^{144}$ Zeisberger's entry of March 23, 1782, in Bliss, ed., Diary of David Zeisberger, 1: 80. In retaliation, the Delawares captured a group of American militia, including Colonel William Crawford of Williamson's command. Though Crawford had not committed atrocities against the Delawares, he received a death sentence from Wingenund and was ritually tortured. For an extremely riveting and graphic narrative on the ordeal of Colonel Crawford see Eckert, That Dark and Bloody River, 379-393. See Heckewelder, Narrative of the Mission, ed., Connelley, 447; Heckewelder, An Account of the Indian Nations, 285-286.

145 Weslager, The Delaware Indians, 317. 
Gnadenhutten symbolized the death knell of Moravianism and the peace faction within the council as influences during national development. ${ }^{146}$ Delawares never forgot Gnadenhutten and blamed Moravian missionaries for weakening Delawares so the Pennsylvania militia could easily slaughter them. ${ }^{147}$ Christian Delawares left Captives Town on the Sandusky and gained refuge with The Big Cat and the Turkey Delawares on the Miami River, west of the Muskingum. ${ }^{148}$

The death of White Eyes, the failure of the Fort Pitt Treaty, and the frontier environment of violence, dismembered any chance of a stable Delaware political nation taking root in the Muskingum country. Most importantly, the American Revolution intensified political rivalry within the Great Council at a crucial time in the development of the Delaware nation. Without the guidance of a strong peace leader such as White Eyes, the consensus and fragile unity of the Lupwaaeenoawuk was tested and put through great stress. The council did not have the maturity and experience as a body to withstand conflict within. When tensions increased in the council, the

146 Ibid., 336.

147 Ibid., 342. It could be argued that the Moravian ban on warfare and their influence of pacifism, took the edge off the Christianized Delawares in a frontier environment where martial assertion was a necessity for survival. For an in depth analysis of the ramification of Moravianism and pacifism on Delaware social structure and gender transformation see the studies of Schonenberger, Lenape Women and the Colonial Encounter; Radloff, "Moravian Mission Methods." The example of the prominent Delaware known as Glikhikan offers both the symbolism and tragedy of the Moravian movement within Delaware culture. At Gnadenhutten, Isaac Glikhikan, a once dangerous and feared Delaware warrior, met a violent death as a pacifist. See Heckewelder in Wallace, ed., Travels of Heckewelder , 94-95, 410.

${ }^{148}$ Toward the end of the Revolution, Zeisberger founded New Gnadenhutten in Michigan. Between 1793-1815, Heckewelder moved a fragment of the Moravian Christians back to the Muskingum to establish new towns at Goshen, Pettquoting, and New Fairfield. He settled other Delawares near the Thames River in Ontario, where they built successful and prosperous settlements. During the War of 1812, the missions were used by the British as a garrison and thus became a target for the American forces of William Henry Harrison, who torched the community in 1813 in the aftermath of the American victory at the Battle of Moraviantown. The Moravians joined other Delawares in Indiana Territory and later moved with them to Kansas Territory in 1832. The last Moravian mission among the Delawares was established in 1837 at Westfield in Kansas. The missionaries lost prestige among the non-Christian Delawares, many of whom were now "openly hostile" to Christianity being spread to their people. See Weslager, The Delaware Indians, 347-348, 352, 384; Volume II of Bliss, ed., Diary of David Zeisberger. 
Wolf tribe took control of the nation, both politically and physically (with the removal of Christian Delawares). For the survival of the Delawares, the factionalism would have to be dealt with and the wounds healed among the Turtle and Turkey peace chiefs and war leaders of the Wolf tribe. The Delawares had to prepare themselves to face an aggressive and restless American nation that had won its independence, and with it, the belief that western expansion into the Ohio country was a right of conquest. 


\section{Chapter VI}

\section{"a nation ... shattered, wrecked, and severed": The Decline of the Delaware Nation, 1783-1795}

The post-Revolution Delaware nation no longer had the political maneuverability of choosing sides, a position enjoyed during the Seven Years' War and American Revolution. After 1783, driven from the Muskingum River valley, Delawares were at the mercy of the United States government. The Delaware council was forced to rebuild a consensus, not an easy task in the aftermath of the national schism caused by the American Revolution. It was vital for Delawares to preserve their political nation and at the same time protect themselves from American encroachment. To do so, the Delawares joined the federation of Northwest Indian tribes. Delawares, Shawnees, Miamis, Wyandots, Ottawas, among others, bonded together in common cause of resistance to the territorial advances of the United States. In the Great Council of the Lupwaaeenoawuk, Delaware chiefs and war captains focused on both unity as a nation and solidarity with the Indian nations of the Northwest. This was difficult to achieve. Confederation prerogatives greatly challenged the cohesiveness and identity of the Delaware nation. The split in the Delaware council also required a period of reconciliation and healing. The process of rapprochement between factions was not given time to work itself out. The political realities of an expanding American nation made confederation issues more vital to the Delawares than bringing together the factions that severed the nation.

As peace talks between the Americans and British commenced in Paris, the Governor of Canada, General Sir Frederick Haldimand, asked the Delawares and other Indian allies of the British "not to push the War into the Enemies Country but [to] defend your own" lands. He reminded the Indians that they would receive assistance from the British. ${ }^{1}$ This, however, was an

${ }^{1}$ Haldimand to Captain Arent De Peyster at Detroit, December 1782, in Downes, Council Fires on Ohio, 281. Haldimand, a Swiss mercenary, also presided over Indian affairs for 
idle promise. The Indians who sided with the British during the American Revolution did not receive "lasting gratitude and protection." The interests of the western Indian nations were ignored during the peace talks in Paris that ended the American Revolution. ${ }^{2}$

By the terms of the Treaty of Paris in 1783, the British recognized the Mississippi River as the western boundary of the United States. They would retain a presence in frontier posts on the Great Lakes at Niagara, Detroit, and Michilimackinac for three years to give British traders time to withdraw. After that time, the United States gained jurisdiction over the Indian nations of the Northwest Territory. ${ }^{3}$ When the pro-British Indians complained that they had been "abandoned to their enemies," the Earl of Shelburne, who was the head of the British ministry, assured them that "they were remitted to the care of neighbours, whose interest it was as much as ours to cultivate friendship with them. ..." 4

Shelburne's optimism was not shared by the Delawares. After the rumored murder of White Eyes and the massacre of Christian Indians at Gnadenhutten, many Delawares came to hate Americans. In his rhetoric, the Wolf war leader Buckongahelas denounced the United States. Buckongahelas maintained that there were more bad whites in proportion to the good. $\mathrm{He}$ condemned American slaveholders who "enslave those who are not of their colour, although created by the same Great Spirit." He told John Heckewelder that these same Americans would enslave the Indians "if they could, but they cannot do it, they kill us. I know the Long Knives; they are not to be trusted." 5

This lack of trust only compounded the confusion within the political environment of the post war Ohio country. The Delaware nation faced new problems after the peace at Paris had been concluded in 1783. The British, Americans, and northwestern Indian nations had different geopolitical agendas. The British in Canada encouraged the Indians to remain peaceful, but to be

the British Crown from the last days of the American Revolution throughout the peace negotiations in Paris.

${ }^{2}$ Colin G. Calloway, Crown and Calumet: British-Indian Relations, 1783-1815 (Norman: University of Oklahoma Press, 1987), 6-7; Calloway, American Revolution in Indian Country, 273-274.

${ }^{3}$ Mohr, Federal Indian Relations, 93; Calloway, Crown and Calumet, 8.

${ }^{4}$ Earl of Shelburne in Calloway, Crown and Calumet, 8.

${ }^{5}$ Buckongahelas in Heckewelder, An Account of The Indian Nations, 81. 
vigilant and to defend their country from the encroachment of the United States. The British ministry hoped to preserve the valuable western fur trade and retain Canada as a royal possession. Most importantly, the British had no intention of confronting the United States over this Indian territory from the Ohio to the Mississippi. ${ }^{6}$

American Indian policy in the west vacillated during this period. During the later years of the Articles of Confederation government, the United States approached diplomacy with Indian nations through the pretensions of "rights of conquest" ideology. In 1784, at Fort Stanwix, the United States commissioners diplomatically mauled the Six Nations of Iroquois delegation. The American commissioners would not deal with the Iroquois as a federation of nations but, to sap them of unity and strength, dealt with them as individual tribes. The leaders of the Iroquois were reduced psychologically when the American official, James Duane, dismantled their air of "perfect equality" and reminded them that they were not a "free and independent nation" but a "subdued people" who were defeated in battle and thus part of the peace settlement between Great Britain and the United States. ${ }^{7}$

At Stanwix, Aaron Hill, a prominent Mohawk leader, attempted to speak for the Delawares, Ottawas, Chippewas, and Shawnees, as well as the Choctaws and Creeks of the southern nations. Hill demanded that the Ohio River boundary, as agreed upon earlier in 1768 at the Treaty of Fort Stanwix, remain as the dividing point between the western Indian nations and Anglo-America. American commissioners and the Seneca leader, Captain John O'Bail (known as Cornplanter) quickly silenced him. Cornplanter reminded Hill that the western tribes "must consult [amongst themselves] of what part they must cede to the United States." ${ }^{8}$ The Iroquois interests in Ohio and Pennsylvania were terminated at Stanwix in $17844^{9}$

${ }^{6}$ Downes, Council Fires on Ohio, 280-281 and Stanley Elkins and Eric McKitrick, The Age of Federalism: The Early American Republic, 1788-1800 (New York: Oxford University Press, 1993), 126.

7 James Duane, Oct. 20, 1784, in Ford, ed., Journals of the Continental Congress, 21: 152-155; Wallace, Death and Rebirth of Seneca, 197-198. The Treaty of Fort Stanwix was signed on October 22, 1784. Despite the guise of "rights of conquest," Congress let the Six Nations retain part of their traditional lands. Also see Downes, Council Fires on Ohio, 289-293.

${ }^{8}$ Cornplanter in Jennings, Ambiguous Iroquois Empire, 16. Despite the establishment of a western boundary at the Ohio, the Fort Stanwix agreement in 1768 was a disaster for the western Indians. The Six Nations, guided by Sir William Johnson and without the consent of the 160 
The United States then turned its diplomatic attentions to the Indian nations of the Northwestern Confederation. In 1783 a Congressional Committee reported that the Indians west of the Ohio River were "not in a temper to relinquish their territorial claims, without further struggles." 10 The Ohio and Great Lakes nations had bounded together in opposition to the 1768 Stanwix Treaty. The Indian Confederation reached fruition under the encouragement of Sir John Johnson, the British superintendent and the son of the late William Johnson, and Thayendanega (Joseph Brant) of the Mohawk nation. Both saw an opportunity to block the expansionist goals of the United States by supporting the federation and their demands for an Ohio River boundary. $^{11}$

The Delawares had always resisted inclusion into a confederation. Despite their military alliances with the Shawnees and Wyandots during the Seven Years' War and American Revolution, they strove to maintain the autonomy and unity of the three animal tribes within the nation. They were not dependent upon the council fires of confederations, whether it was the Iroquois at Onondaga or western Algonquians at Detroit. This self-sufficient position changed with the conclusion of the American Revolution.

After the Revolutionary War, Delawares who were driven from the central towns on the Muskingum and Tuscarawas were scattered to the Lower Sandusky region along Lake Erie and further west to the Mad River bordering Kentucky country, to the Maumee River region and to the series of Indian towns on the Miami River known as the Glaize. Eventually by 1789, a splinter group of Delawares, together with a band of Shawnees, were invited by Baron de

western nations, sold Indian hunting grounds south of the Ohio and opened up Kentucky for settlers, squatters, and speculators from Virginia. This immigration into the hunting grounds of the Shawnees precipitated Lord Dunmore's War in 1774. For a solid analysis on the ramifications of this treaty see McConnell, A Country Between, 244, 248-256, 261-263.

${ }^{9}$ Fort Stanwix Treaty of 1784 with the Six Nations, in Indian Affairs: Laws and Treaties, Vol II, compiled and edited by Charles J. Kappler (Washington, D. C.: United States Government Printing Office, 1904), 2: 5-6; Reginald Horsman, Expansion and American Indian Policy 1783-1812 (East Lansing: Michigan State University Press, 1967), 17-20.

${ }^{10}$ Congressional Committee, 1783 in Ford, ed., Journals of the Continental Congress, 25 : 681-683.

${ }^{11}$ Calloway, Crown and Calumet, 14; Downes, Council Fires on Ohio, 282-283. 
Carondelot, the Spanish governor of Louisiana to settle in current day Cape Girardeau, Missouri. $^{12}$

Delawares and other Ohio Indians "entered into a formal league" with the Indians of the Great Lakes and western regions. They united to block American expansion across the Ohio. ${ }^{13}$ The Delawares became immersed in the "village world" of mostly Algonquian-speaking nations, all motivated by a commonality--the defense of their Ohio and Great Lakes homeland. Wyandots and Ojibwas (Chippewas) comprised the Detroit towns, while Ottawas, Wyandots, and Delawares lived in the Lower Maumee towns. The Big Cat's and Buckongahelas's Delawares lived with Shawnees and Miamis in the Upper Maumee villages. Delawares, Mingos, Ottawas, and Wyandots lived together in the towns of the Sandusky regions. To the extreme west, Potawatomis and Miamis resided in the St. Joseph region (located west of the Wabash River), and to the south of the Wabash, a large concentration of Potawatomi and Wea villages. British traders lived in many of these towns and villages. ${ }^{14}$

In these villages, political and ethnic cohesion was fluid; ever changing according to the circumstances. Unity manifested itself when these Algonquian tribes felt the pressure of an American invasion. ${ }^{15}$ The confederation existed in this northwest Indian environment to counter American expansion. The land west of the Ohio River belonged to the Indian nations as a collective whole. One group could not cede territory without confederation consent. ${ }^{16}$

During the Revolutionary War, settlers slowly assaulted the boundary line by crossing the Ohio River. Congress realized that it could not restrain western movement. Embryonic land ordinances in 1784 and 1785, pushed by Thomas Jefferson, laid the groundwork for territorial expansion west of the Ohio and territorial self-government. ${ }^{17}$ To deal with the Northwestern

${ }^{12}$ White, The Middle Ground, 413-468; Weslager, The Delaware Indians, 319; Hinderaker, Elusive Empires, 244-246.

${ }^{13}$ Heckewelder, Narrative of the Mission, ed., Connelley, 492.

${ }^{14}$ See maps in White, The Middle Ground, 414-415; Helen Hornbeck Tanner, ed., Atlas of Great Lakes Indian History (Norman: University of Oklahoma Press, 1987), 87-89.

${ }^{15}$ White, The Middle Ground, 413-414.

${ }^{16}$ Ibid., 435 .

${ }^{17}$ Hinderaker, Elusive Empires, 228-229. Eventually the Northwest Ordinance of 1787 was adopted to establish a western policy of a gradual and orderly expansion under the control of Congress. 
tribes for land cessions and treaties, Congress instructed the appointed commissioners to avoid and "discourage every coalition and consultation" that might encourage the Indian nations to unite and push for a common agenda of resistance, whether passive through diplomacy or aggressive through war. $^{18}$

Against the "internal pact" of the confederation of tribes, which prohibited individual negotiations, the Delawares, Wyandots, and a band of Ottawas and Chippewas met with American commissioners at Fort McIntosh (Beaver, western Pennsylvania) in January of 1785 to negotiate a treaty. The American representatives sought a new western boundary with the Ohio tribes. They reminded the Indian leaders, who made the trek to Fort McIntosh, that the Six Nations of Iroquois had been defeated and that the British would no longer protect the Ohio tribes. A Delaware leader at the treaty talks tried to reason with American officials by pointing out that "I think that ... the country is mine; and as our children grow up, we will tell them that the [Ohio] country is ours." 19

The pleas did not have the effect hoped by Delaware leaders. In exchange for protection of the United States government, the Delawares and Wyandots gave up northern sections of the Muskingum Valley for white settlement and thus weakened the sanction of the Ohio River as a boundary line. Part of the reduced boundary was to begin at the Cuyahoga River and run to the "portage between [the Cuyahoga] and the Tuscarawas branch of Muskingum...." The western boundary ran to the Miami River. ${ }^{20}$ Article IV of the treaty recognized Delaware and Wyandot claims to land for hunting and settlement. Article VI prohibited all Indians to live on land ceded to the government and gave the United States full rights to settle the "lands east, south and west of the lines" outside of the Delaware-Wyandot reserve. ${ }^{21}$

18 Resolutions of Continental Congress, March 19, 1784, in Ford, ed., Journals of the Continental Congress, 26: 152-155.

${ }^{19}$ A Delaware leader to American commissioners at Fort McIntosh, Jan. 8, 1785, in Downes, Council Fires on Ohio, 292-293.

20 Article III of Treaty of Fort McIntosh, Jan. 21, 1785, in Francis Paul Prucha, Documents of United States Indian Policy 3rd ed. (Lincoln: University of Nebraska Press, 2000), 5 .

${ }^{21}$ Articles IV and VI in ibid., 6. 
The treaty at Fort McIntosh reveals much about the Delaware polity at that time. Captain Pipe desperately attempted to retain Wolf preeminence in the post-war Delaware council. Pipe, whose pro-British stance led the Delawares to defeat, had fallen out of favor in the Delaware Great Council and was trying to reestablish his tarnished reputation. Leaders of the Turtle and Turkey tribes accused Pipe of taking Delawares off the road of peace, leading them to war, "diminishing and impoverishing them." 22 John Heckewelder noted that the "Wolf Tribe, with Captn. Pipe at their head, who had wrested the power of governing the Nation, from the Turtle tribe, was accused both by the latter and the Turkey Tribe, of being incompetent to govern the nation. ..." 23 The Big Cat criticized Pipe of weakening the Delaware nation when he deviated from the pro-American course of the Turtles and Turkeys and removed the Moravian missionaries and their converts from the Muskingum. ${ }^{24}$ Pipe's sudden pro-American stance did not sit well with the Delaware Great Council. The growing popularity of the war leader Buckongahelas indicated that Delaware consensus was drawn towards full participation in the Indian Confederation. In a sense, the national agendas (individual peace treaties and diplomacy with the United States) of the Delawares were stifled and shelved by adherence to the antiAmerican stance of the federated western Indian nations and with this loyalty, the probability of war.

In a complete reversal of political sentiment, Pipe sought out American commissioners to sign a binding treaty of peace. Pipe, who still was bitter over British betrayal, believed that a friendship with the United States would keep the Delaware nation away from the machinations of the British and Northwestern Confederation. Pipe and the ancient Turtle leader Wingenund, led the Delawares at the Fort McIntosh treaty talks. They negotiated with territorial governor George Rogers Clark, and commissioners Richard Butler and Arthur Lee. Pipe ignored council

${ }^{22}$ Heckewelder, Narrative of the Mission, ed., Connelley, 455.

23 Ibid., 455 .

24 Ibid., 455. According to C. A. Weslager in The Delaware Indians, 319, The Big Cat eventually replaced Pipe as the leader of the Wolf tribe. Regarding The Big Cat's clan affiliation, Weslager is in error. The Big Cat was not a Wolf. His name, Machingwe Pushis (Machingwe means large) is a Unami word (Turtle and Turkey) and not a Wolf term (Munsee). See Raymond Whritenour, A Delaware-English Lexicon of Words and Phrases (Butler, New Jersey: Lenape 
protocol when he ceded Delaware land without consent of the Turkey and Turtle leaders. He was eager to gain peace with the United States and even disregarded the objections of Buckongahelas, who was the Wolf war captain and a prominent councilor. ${ }^{25}$

United States officials attempted to reconcile the factions, and at the same time, increase pro-American sentiments within the Delaware Lupwaaeenoawuk. They added a separate article to the stipulations of the treaty of 1785 . The Delawares, at the insistence of the United States commissioners, agreed that Killbuck, The Big Cat, and Wicocalind, also known as Joseph White Eyes, the son of Captain White Eyes, would be pardoned for taking "up the hatchet for the United States, and their families, [would] be received into the Delaware nation, in the same situation and rank as before the war." They were also assured "their due portions of the lands" would be given to the Delawares and Wyandots as a result of the treaty. ${ }^{26}$

The United States hoped to make a major treaty with the rest of the confederation. The Delawares had an opportunity to reestablish themselves as the "Grandfathers"--the most ancient and revered peacemakers among all Algonquians. General Richard Butler enlisted Wingenund to serve as a mediator between the United States and western nations. Butler considered Wingenund as "old, experienced, and sensible, to go to the nations ... and use every effort to bring them to

Texts \& Studies, 1995), 90, 143. On The Big Cat being a chief of the Turkey phratry, see Thurman, "Delaware Indians in Ethnohistory," 102.

${ }^{25}$ White, The Middle Ground, 437; Heckewelder, Narrative of the Mission, ed., Connelley, 455-456.

${ }^{26}$ Separate Article in Article III of Treaty of Fort McIntosh, Jan. 21, 1785 in The New American State Papers, 1789-1860: Indian Affairs, Vol. 4 Northwest, gen. ed., Thomas C. Cochran (Wilmington, Delaware: Scholarly Resources, Inc., 1972), 4: 20. Killbuck, once the heir apparent as principal man of the Delaware nation, was never fully accepted back into the Great Council. As Colonel William Henry, Killbuck and his band fought as allies of the Continental Army and had shed Delaware blood in an engagement at the principal Delaware town of Goschgoschunk on the Muskingum River. In 1789 Killbuck, while on a diplomatic mission, was beaten by a group of Delaware warriors outside of Fort Harmar (present-day Marietta, Ohio). Killbuck spent his remaining years as a devoted Christian and a constant companion of David Zeisberger at the mission town of Pettquoting (New Salem, Ohio). He died in 1811. See Wallace, ed., Travels of John Heckewelder, 419-420; Sipe, Indian Chiefs of Pennsylvania, 419-420; Weslager, The Delaware Indians, 318-320. 
the treaty ... in his artful manner." 27 Butler also dispatched The Big Cat to the Wabash and Miami towns of the Mahicans and Miamis to persuade them to come in to the treaty talks. ${ }^{28}$ Their attempts with these nations failed. Only the Shawnees listened to the overtures of the Delawares and appeared at Fort Finney at the mouth of the Miami River to negotiate a treaty. Tetapachksit ("One Who Has Been Split”) a chief headman of the Turtle Delawares, told the Shawnee war captains that his people "had laid down the hatchet, and would never more take it up." He asked the Shawnees "to be strong and follow his example." 29 The treaty, in essence, reiterated the same conditions proposed at Fort McIntosh. The Shawnees were bullied into acknowledging the United States as the "sole and absolute sovereigns" of land west of the Ohio ceded by Great Britain. ${ }^{30}$

The Northwest Indian Confederation met in Detroit in December 1786 to denounce all "separate treaties" made without confederation consent. The Northwestern tribes maintained that "by the united voice of the Confederacy holding all partial treaties as void and of no effect." This in essence was an indictment aimed at the treaties at Fort McIntosh with the Delawares and Wyandots and Fort Finney with the Shawnees. Both agreements were nullified by the Confederation. $^{31}$

27 “General Butler's Journal,” December 25, 1785, in Neville B. Craig, ed., The Olden Time: A Monthly Publication Devoted to the Preservation of Documents and Other Authentic Information in Relation to the Early Explorations and the Settlement and Improvement of the Country Around the Head of the Ohio (1848; reprint, Cincinnati, Robert Clarke Co., 1876), 2: 503

28 Journal entry of General Butler, Jan. 19, 1786, in ibid., 2: 517.

29 Journal entry of General Butler, Jan. 28, 1786, in Colin G. Calloway, ed., First Peoples: A Documentary Survey of American Indian History (Boston: Bedford/St. Martin's, 1999), 198.

${ }^{30}$ Butler to Shawnees, Jan. 31, 1786, in ibid., 2: 523-524; Prucha, American Indian Treaties, 51-53. Shawnees, who opposed the Fort Finney Treaty and its new boundaries, committed brutal raids in Kentucky during the summer of 1786. See Wiley Sword, President Washington's Indian War: The Struggle For the Old Northwest, 1790-1795 (Norman: University of Oklahoma Press, 1985), 37-39; White, The Middle Ground, 437; Hinderaker, Elusive Empires, 240-241.

31 The Confederation of Northwest Indian nations, Dec., 1786, in American State Papers, 1832-1861: Indian Affairs, (Washington, D. C.: United States Government Printing Office, 1904), 1: 8. 
The United States government stood by these treaties and went further with regards to their assertion of territorial rights in the Ohio. The Northwest Ordinance of 1787 slowly altered government response to Indian hostilities in the Ohio. The land ordinance authorized Congress to make laws regarding Indian policy, "founded on justice and humanity." Congress hoped that past wrongs to the Indians would be made right and "peace and Friendship" would be preserved at all costs. $^{32}$

The Land Ordinance also released the floodgates of settlement into the Ohio. Those Ohio Delawares who lived within the confines of the reserve as established by the concessions made at Fort McIntosh in 1785, were slowly "hemmed in." 33 Delawares also suffered from famine when their corn crops failed during a cold snap and game became scarce. David Zeisberger lamented the state of the Ohio Delawares who "a few years ago greatly flourished, but since the old chiefs, Netawatwe[e]s and White Eyes, are dead, [the Delaware nation] goes with hasty steps to ruin." 34

Zeisberger also reported that the Delawares who were dispersed throughout the Northwest Territory were in a "grievous condition," as they were without a "steadfast place" or a traditional homeland. They asked the Six Nations for land and were denied by leaders of the Iroquois who told the Delawares that after the Fort Stanwix Treaty in 1784, "they had themselves not a foot of land they could call their own." 35 They then made requests to the Wyandots, who had originally given the Delawares land in the Ohio. The Wyandots told them

32 Northwest Ordinance of 1787 in Francis Paul Prucha, American Indian Policy in the Formative Years: The Indian Trade and Intercourse Acts, 1790-1835 (1962; reprint, Lincoln: University of Nebraska Press, 1970), 26; Stephen L. Schechter, ed., Roots of the Republic: American Founding Documents Interpreted (Madison, Wisconsin: Madison House, 1990), 263. Under this ordinance, appointees of Congress governed the Northwest Territory. The territory could send a non-voting member to Congress when five thousand white males resided within the particular territory. When the population of a territory reached 60,000 it could apply for statehood. Five states, Ohio, Indiana, Illinois, Michigan, and Wisconsin were eventually carved from the Northwest. See Edmund S. Morgan, The Birth of the Republic 1763-1789 (Chicago: The University of Chicago Press, 1977), 114-115.

33 Entry of David Zeisberger from Fort Wayne, Oct. 18, 1787, in Bliss, ed., Diary of David Zeisberger, 1: 373-374.

${ }^{34}$ Entry of Zeisberger from Fort Wayne, Oct. 18, 1787, in ibid., 1: 373-374.

35 Ibid., 1: 373-374. 
they "would make them no more offers" for new land. ${ }^{36}$ Out of sympathy for displaced

Delaware bands, the Miami Indian nation gave them a tract of land that extended from the Miami to the Wabash Rivers. Swamps surrounded this land. ${ }^{37}$

The American government hoped that the Delawares could serve as mediators and peacemakers among the Northwestern Confederation. As the United States veered from its "rights of conquest" ideology, it saw the diplomatic potential of the Delawares to bring peace to the Ohio country. Charles Thomson, the Secretary of Congress, believed that it was necessary to reach out to the principal Delaware leaders and their followers who had been "driven from the Muskingum" and to "quiet the minds of the Delaware in Respect to the mournful Slaughter of their friends" at Gnadenhutten. Thomson hoped that the Delawares would not condemn Congress for actions taken by the Pennsylvania Militia and their slaughter of innocent Christian Delawares. $^{38}$

However, the United States government had to shelve its individual concern for the Delaware nation and turn attention to confederation matters. In October of 1787, Congress directed Arthur St. Clair, the territorial governor, to meet with the Confederation and to address "all causes of controversy, so that peace and harmony may continue between the United States and the Indian tribes." 39 He was instructed to negotiate a "boundary advantageous to the United States" and to extinguish, by purchase, Indian claims to land desired by Congress. ${ }^{40}$ St. Clair addressed leaders of the western nations in council at the mouth of the Detroit River on July 13,

36 Ibid., 1: 373-374.

${ }^{37}$ Entry of Zeisberger, Oct. 17, 1787, and July 25, 1788, in ibid., 1: 373-374, 429. After the Treaty of Greenville in 1795, the Miamis permitted Delawares to settle in the White River region of Indiana Territory as dependents of the Miamis. See Anthony F. C. Wallace, "Political Organization and Land Tenure Among the Northeastern Indians, 1600-1830," Southwestern Journal of Anthropology 13 (1957): 317.

${ }^{38}$ Charles Thomson to Territorial Governor Arthur St. Clair, New York, April 11, 1788, in The Territorial Papers of the United States, 5 vols., compiler and ed., Clarence Edwin Carter, The Territory Northwest of the River Ohio, 1787-1803 (Washington, D. C.: United States Government Printing Office, 1934), 2: 103.

39 Instructions of Congress to Governor St. Clair, October 1787, in Ford, ed., Journals of the Continental Congress, 34: 286-287.

${ }^{40}$ Additional Instructions of Congress to Governor St. Clair, July 2, 1788, in Territorial Papers of the United States, ed., Carter, Northwest 2: 117. 
1788 , to chastise the actions of their warriors who raided along the Ohio River after peace treaties had been concluded. He reminded them that the United States was "sincerely desirous of Peace," but also warned the chiefs: "if you will have War, why you shall have War." 41

In January 1789, St. Clair, Josiah Harmar, and Richard Butler negotiated a treaty at Fort Harmar with the Delawares, Wyandots, Chippewas, Ottawas, Sauks, and Potawatomis. In this agreement the western tribes, after insisting that the boundary line be moved to the Muskingum, reluctantly acknowledged the boundaries as determined at Fort McIntosh in 1785. The treaty also gave the United States preempted rights over any lands that the Western Confederation might sell in the future. ${ }^{42}$ To gain the confederation's verification of the McIntosh Treaty, St. Clair gave presents and goods valued at 6,000 dollars. ${ }^{43}$

While St. Clair believed that the "confederacy [was] entirely broken" through the Northwestern Confederation's acceptance of the territorial cessions made by the Delawares and Wyandots at Fort McIntosh in 1785 , the treaty was not a binding agreement. ${ }^{44} \mathrm{He}$ made a diplomatic blunder when he presented the Indian headmen with black wampum belts and not the white belts of peace that would have validated this agreement. St. Clair also received mostly the

${ }^{41}$ Governor St. Clair to confederation Indians in council on the Detroit River, July 13, 1788, in ibid., 2: 127.

42 Articles Third and Fourth of the Treaty of Fort Harmar with the Western Indian Nations, January 9, 1789, in Territorial Papers of the United States, ed., Carter, Northwest 2: 175-176. In the seventh article, the United States required all traders entering Indian country to be licensed by the Northwest Territorial governor. See Article Seven in ibid., 2: 176-177. The United States government carried out two separate treaty talks at Fort Harmar (current day Marietta, Ohio) on January 9, 1789. One agreement was reached with the Six Nations, with the exception of Joseph Brant and the Mohawks who refused to attend. The Six Nations Confederation agreed to the terms of the Treaty of Stanwix in 1784, which set permanent boundaries between the United States and the Six Nations. The treaty also required the Iroquois to relinquish and cede to the United States "all Claim to the Country west of the said [western] Boundary" of the Six Nations. See Articles First and Second of the Treaty of Fort Harmar with the Six Nations, January 9, 1789, in Territorial Papers of the United States, ed., Carter, Northwest, 2: 182-183.

${ }^{43}$ Articles First and Second of the Treaty of Fort Harmar with the Western Indian Nations, January 9, 1789, in ibid., 2: 174-175.

${ }^{44}$ Governor St. Clair's report on the Treaties of Fort Harmar to President George Washington, New York, May 2, 1789, in Calloway, ed., Revolution and Confederation, vol. 18 of Early American Indian Documents, 18: 511 
signatures of men who were not established civil or war leaders within their respective nations. There were only four principal leaders within the confederation who attended. Many of the chiefs who signed their marks had never negotiated with Euro-Americans. ${ }^{45}$

While the Delawares had seasoned councilors at the treaty, the Lupwaaeenoawuk rejected this treaty. The signatures of the Delawares included Captain Pipe and his councilors, Pekelan, and Teataway, all representatives of the Wolf tribe. Wingenund, was the sole representative of the Turtle/ Turkey tribes present at Fort Harmar. Consensus rejected Pipe's continual push for accommodating American demands. According to Heckewelder, the Delawares who followed the popular Wolf war captain Buckongahelas "constituted two-thirds of the nation--not one of who were present." ${ }^{46}$ The Great Council made reference to him as the "George Washington" of the Delaware nation. ${ }^{47}$

Buckongahelas, much like Captain Pipe a decade earlier, was leading Delawares down the disastrous road of war. By the end of 1791, Captain Pipe's Delawares on the Upper Sandusky, together with bands of Wyandots, were the lone holdouts for peace with the Americans. They asked, "What can we do? We are but two, and all other nations are for war. We must expect to have the nations upon us, if we do not agree with them." Out of sync with the Delaware political mainstream, Pipe and his people left the Sandusky region and moved northwest to live with the Ottawas and Wyandots in the Lower Maumee River villages. Other Munsee-Wolf people led by Captain Snake left the Sandusky in 1791 to take refuge with Cornplanter's Senecas in the Allegheny country of northwestern Pennsylvania. ${ }^{48}$

45 White, The Middle Ground, 446-447.

46 John Heckewelder in Wallace, ed., Travels of Heckewelder, 220; Treaty of Fort Harmar, Jan. 9, 1789, in Calloway, ed., Revolution and Confederation, vol. 18 of Early American Indian Documents, 18: 494; Separate articles of Fort Harmar Treaty, Jan. 9, 1789, in "Frontier Wars," Series U, vol. 23: 154 of Lyman C. Draper Manuscripts, Collections of the State Historical Society of Wisconsin, (microfilm), West Virginia collections, Wise Library, West Virginia University.

${ }^{47}$ Observations of Hendrick Aupaumut in "Frontier Wars," U 5: 28, Draper Manuscripts.

48 "Narrative of the Journey of Col. Thomas Proctor, to the Indians of the North-West," Pennsylvania Archives, 2nd Series, Blinn and Egle, eds., 4: 483. 
Despite the pressure exerted by St. Clair on the western nations to accept the previously agreed upon boundaries, the Fort Harmar agreement marked a complete departure from the rights of conquest mentality previously held by the United States. Both treaties confirmed the land cessions of the Fort Stanwix Treaty of 1784 and the Fort McIntosh Treaty of 1785 through payment to the Indians, rather than taking the land through military force. ${ }^{49}$ During the administration of George Washington, Secretary of War Henry Knox structured the United States Indian policy in concordance with Washington's vision that American expansion beyond the Appalachians and into the Northwest should be gradual, orderly, and without harm to the Indians. To reach this goal, Washington and Knox hoped to maintain peace between the two cultures until land cessions could be secured from the tribes west of the Ohio. ${ }^{50}$ In this way land could be "wrested from them without another struggle." ${ }^{51}$ The federated Indians would not cede their land west of the Ohio River.

There was a paradoxical dilemma built into the Washington-Knox Indian policy. It became increasingly obvious to the federal government that it could neither use the military to enforce its Indian boundaries nor prevent frontiersmen from entering Indian land in the Ohio. Yet the military was expected to protect American citizens who breached treaty boundaries.

Indians were quick to see the contradictions in the United States Indian policy and its dualism of peace and war. At the Harmar talks in 1789, a Shawnee war captain remarked to territorial judge and land speculator John Cleves Symmes, "if the United States were such lovers of peace" as their leaders described themselves, they would not have chosen the eagle as a symbol, he being the largest and most prideful of all birds--the "enemy of all birds." The Shawnee

49 Prucha, American Indian Policy, 40; Prucha, American Indian Treaties, 56-57; Andrew R. L. Cayton, Frontier Indiana (Bloomington: Indiana University Press, 1996), 124-125.

${ }^{50}$ Prucha, American Indian Policy, 3. According to Thomas Slaughter in The Whiskey Rebellion, Washington, Knox, and other land speculators, hoped that land companies such as The Symmes Associates, Scioto Syndicate, and the Ohio Company would help to keep Ohio settlement orderly. Harmar and St. Clair each held shares in the Ohio Company and Washington held extensive holdings near Pittsburgh and on the Kanawha River in current-day West Virginia. See Richard H. Kohn, Eagle and Sword: The Federalists and the Creation of the Military Establishment in America, 1783-1802 (New York: The Free Press, A Division of Macmillan Publishing Co., Inc., 1975), 100. 
further observed: "You have not only put one of the instruments of war, a bundle of arrows, into one of his hands [talons], and rods in the other, but have painted him in the most fearful guise, ... in posture of attack upon his prey." 52

The national government's hopes for a humane policy were replaced by the grim realism that Indians would resist territorial encroachment before they would peacefully yield their country. ${ }^{53}$ Military resistance would be detrimental to the original intent of American national honor in its treatment of native people. Indian policy would move into the realm of the ethnic cleansing of a region.

The Northwestern Confederation refused to acknowledge any treaty between Americans and Indians that specified a reduced boundary. In council, these nations decided that they would unite in common cause and "assist in repelling the Enemy, who had come into their Country, to take their Land from them." They also agreed that the Moravian missionaries and their Christian Indian followers could live and practice their faith throughout Indian country. They would, however, be required to fight the whites if necessary. Indian leaders mandated that Christian Indians who refused to fight, would be put to death, as would the missionary who influenced them to be peaceful in times of war. ${ }^{54}$ Many Moravian missionaries appealed to the British at Detroit for protection against the confederation Indians. The British permitted these missionaries asylum on the Canadian side of the Detroit River. ${ }^{55}$ The Delawares, Shawnees, Ottawas, Miamis and others looked to the confederation as a mechanism to "unite all their strength and forces, in compelling the People of the United States, to keep within certain bounds." The British, whose traders supplied the Indians with goods while their military provided protection, were not banned from Indian country. ${ }^{56}$ Alexander McKee, the British trader and Indian agent, encouraged

${ }^{51}$ Washington to Congressman James Duane on September 7, 1783, in Saul K. Padover, ed., The Washington Papers (New York: Harper and Brothers Publishers, 1955), 350-352.

52 Shawnee chief to Symmes, Heckewelder's journal entry, August 18, 1792, in Wallace, ed., Travels of Heckewelder, 275.

53 Horsman, Expansion and Indian Policy, 95; Kohn, Eagle and Sword, 98.

54 Heckewelder, Narrative of the Mission, 493.

55 Ibid., 494-495.

56 Ibid., 492. 
this pan-Indian unity and promised the Indians that the British could be depended on for military and economic assistance. ${ }^{57}$

The Northwestern Confederation was highly successful in repelling the advances of the United States military. Delaware warriors participated in a series of confederation victories over American armies. On October 17, 1790, the Miami leader known as Little Turtle led a coalition of Miami, Delaware, and Shawnee warriors and defeated General Josiah Harmar in the Wabash and Maumee valleys. ${ }^{58}$ Then in mid October of 1791, The Miami warriors of Little Turtle, the Shawnees of Blue Jacket, and Delawares led by Buckongahelas, together with an auxiliary force of Canadians led by the white renegade Simon Girty attacked, surrounded, and thoroughly defeated the army of Arthur St. Clair in the Wabash Valley. ${ }^{59}$

The defeats of Harmar and St. Clair did much to bolster the confidence of the Northwestern Indians. David Zeisberger observed that the Indian nations of the Northwest Territory "labored for unity" and vowed to "stand together, and hold fast by one another." 60 Also in the aftermath of these victories, Captain Pipe and The Big Cat, who spearheaded the peace faction in the Delaware Great Council, failed to gain a footing and were shouted down. In futility, trying to maintain authority, Captain Pipe sent word to Washington and assured him if the President could control the actions of American settlers and remove the military from the "forts which stands on our land,"

57 Alexander McKee, on behalf of the British King, July 1, 1789, in General E. A. Cruikshank, ed., The Correspondence of Lieut. Governor John Graves Simcoe, With Allied Documents Relating to His Administration of the Government of Upper Canada, 5 vols., Vol. 1. 1789-1793 (Toronto: Ontario Historical Society, 1923), 1: 36.

${ }^{58}$ Kohn, Eagle and Sword, 106; Horsman, Expansion and Indian Policy, 86; Tanner, ed., Atlas of Great Lakes Indian History, 72-73, 89; Otho Winger, "The Indians Who Opposed Harmar," The Ohio State Archaeological and Historical Quarterly 50 (1941): 55-59; Washington to Knox, Mount Vernon, Nov. 19, 1790, in Territorial Papers of the United States, ed., Carter, Northwest, 2: 311.

${ }^{59}$ Daniel Bradley, Journal of Captain Daniel Bradley: An Epic of the Ohio Frontier (Greenville, Ohio: Frank H. Jobes and Son, 1935), 24. Arthur St. Clair, Narrative of The Campaign Against the Indians, 1791 (Salem, New Hampshire: Ayer Company, Publishers, Inc., 1991), 47; Slaughter, The Whiskey Rebellion, 106-107. Over 913 Americans were killed, many while fleeing in terror from the confederation warriors. Only 580 of St. Clair's command survived this disaster. This debacle would remain throughout American history as the greatest defeat that the United States military experienced at the hands of American Indians. 
the peace chiefs could restrain the movement of Delaware war parties. ${ }^{61}$ At the council of Indian nations which assembled at the Glaize River, Buckongahelas voiced both Delaware and confederation unity when he stated: "all nations agreed . . that if any one of us were struck, we should consider it as if the whole of the Nations had received a blow and that the whole should join in revenging it. ..." Buckongahelas also revealed the sentiment of the federated Indians for the sake of the Six Nations and Southern nations to take notice, when he urged Delawares, together with their neighbors, to be of "one mind, one Head and one Heart, and we are resolved to stick close by each other \& defend ourselves to the last." 62

The Washington administration was not discouraged at the misfortunes of Harmar and St. Clair. Washington replaced St. Clair, who resigned his commission, with Revolutionary War hero Major General Anthony Wayne on April 9, 1792. Wayne, after taking command, stressed to the Secretary of War, Henry Knox, that "war must progress [for] the Savages have been confident, haughty and insolent from reiterated success." 63 Washington and Knox restrained Wayne from taking immediate action. They still hoped for a peaceful solution and that the confederation Indians would acknowledge, through continued negotiations, the 1789 Harmar Treaty and its boundary stipulations. Both Washington and Knox took into consideration that public sentiment opposed a major Indian war. Knox also wanted to give Wayne the time to train and discipline an efficient military force to be ready in case of diplomatic failures. ${ }^{64}$ The Americans remained rigid with

${ }^{60}$ Entry of David Zeisberger, July 6, 1791, in Bliss, ed., Diary of David Zeisberger, 2: 198.

${ }^{61}$ Delawares in a General Council on the Glaize River with the Shawnees, Miamis, Chippewas, Ottawas, Wyandots, Six Nations, Cherokees, Creeks, Sept. 30, 1792, in White, The Middle Ground, 460. This was one of the last diplomatic actions taken by Pipe, who died in the summer of 1794.

${ }^{62}$ Rhetoric of Buckongahelas at the Glaize Council, Sept. 30, 1792, in Cruikshank, ed., Correspondence of Simcoe, 1: 220.

63 General Anthony Wayne to Knox, in Richard C. Knopf, ed., Anthony Wayne, A Name In Arms: The Wayne-Knox-Pickering-McHenry Correspondence (Pittsburgh: University of Pittsburgh Press, 1960), 71.

64 Michael Darryl Carter, "Nationbuilding and the Military: The Life and Career of Secretary of War Henry Knox, 1750-1806” (Ph.D. diss., West Virginia University, 1997), 327, 330; Harry M. Ward, The Department of War, 1781-1795 (Pittsburgh: University of Pittsburgh Press, 1962), 147-153. Washington wanted Wayne to restrain himself from committing the military into attacking Indian villages until all peace initiatives had been considered and exhausted. 
regard to the Ohio as a boundary line for they contended that the "settlements of the lands over the Ohio founded on the Treaties of Fort McIntosh and Fort Harmar" made an Ohio River boundary line impossible. ${ }^{65}$ They later reiterated by stating that the "Land was sold, \& in part settled." 66

On July 28, a delegation of Delawares, Shawnees, and Wyandots left the Auglaize for the Maumee rapids near the Detroit River to meet with American commissioners. They joined a group of principal headmen of the Ottawas, Miamis, Potawatomis, and Chippewas. Also in attendance at the council were Joseph Brant and other representatives of the Six Nations, volunteering to serve the Northwestern tribes as intermediaries. Brant temporarily persuaded the delegation to accept the Fort McIntosh Treaty and with it, the Muskingum as a boundary. A few of the Indian leaders were then swayed from this agreement overnight after they met with Alexander McKee, who encouraged them to insist upon the Ohio River boundary as agreed upon at Fort Stanwix in 1768. Brant and his delegation argued that the Ohio was an unreasonable demand, "by no means fair.", 67

There was dissent against Brant and his delegation. The war leader Buckongahelas epitomized the defiant nature of both the Delawares and the confederated Indians towards the Americans, British, and Six Nations. Bitter at Brant and the Six Nations for lack of support, he violated protocol when he interrupted Brant in mid-speech by calling him a liar as Brant tried to rationalize the Muskingum boundary. ${ }^{68}$ Later Buckongahelas rose in council when the Six Nations insisted that the Muskingum boundary was "most reasonable" and pointed an accusing finger at

${ }^{65}$ United States Commissioners to Governor Simcoe, June 7, 1793, Navy Hall, in Cruikshank, ed., Correspondence of Simcoe, 1: 349-350.

66 Observation by Heckewelder on the United States commissioners to Joseph Brant at the Maumee Rapids, July 29, 1793, in Wallace, ed., Travels of Heckewelder, 316.

${ }^{67}$ Captain Joseph Brant to Secretary of Indian Affairs Joseph Chew, Niagara, September 26, 1793, in Cruikshank, ed., Correspondence of Simcoe, 2: 68-69. Brant was convinced of the military power of the United States and rightfully accused the British in Canada of instigating the western Indians in their demands for the Ohio River boundary. Brant, recalling the abandonment of his Mohawks by the British in 1783, warned the confederation chiefs that Great Britain would not fight the United States to insure this boundary. See Isabel Thompson Kelsay, Joseph Brant, 1743-1807: Man of Two Worlds (Syracuse: Syracuse University Press, 1984), 500-502.

${ }^{68}$ White, The Middle Ground, 462-463. 
McKee and charged that he was the "Person who advises us to insist on the Ohio River for the line." 69

Confederation leaders signed a document with the clan markings of their respective nations and contended that the Ohio River, as determined at the Fort Stanwix Treaty of 1768, was the boundary line. They asked the American commissioners, that in the interest of peace "you will immediately remove all your People from our side of that River" and for a formal acknowledgement that the Ohio would remain the dividing line "between your People and ours." 70 By the end of August, it became clear to the commissioners that peace with the Indian Confederation could not be secured. $^{71}$

John Heckewelder experienced both the cautious and the militant overtones of the Delawares at this time. Four Delawares visited Heckewelder, who attended the council, and told him that they found "much fault" with the United States sending the armies of Harmar and St. Clair into Indian country. They claimed it was "some of their foolish young People" who fought the Americans over the issues of the Ohio River as a boundary. ${ }^{72}$ A Munsee-Wolf warrior and a Chippewa companion arrived at the talks and "charged both the Brittish \& 5 Nations as the cause of these troubles: they having put the tomahawk into their hands." The Wolf warrior became drunk, and during the night loafed outside of Heckewelder's tent, proclaiming himself to be the

${ }^{69}$ Excerpt from Captain Brant's Journal of the Proceedings at the General Council Held at the Foot of the Rapids of the Miami, August 5, 1793, in Cruikshank, ed., Correspondence of Simcoe, 2: 16; Kelsay, Joseph Brant, 502; Downes, Council Fires on Ohio, 328-329.

${ }^{70}$ Council of the Northwest Indian Confederation to United States commissioners, Miami Rapids, July 27, 1793, in Cruikshank, ed., Correspondence of Simcoe, 1: 402; Council of the Confederation to United States Commissioners, Miami Rapids, July 30, 1793, in New American State Papers, 1789-1860, Cochran, ed., 4: 135; Wallace, ed., Travels of Heckewelder, 316. In Simcoe's document, the Delaware clan signature is that of the Turtle, the Munsee clan signature is the Turkey (this would then be a clan within the Wolf (Munsee) phratry. For a further explanation concerning sub-divisions within the phratries see the testimony of the Delaware informant Mrs. Journeycake in Thurman, "Delaware Social Organization," in Delaware Indian Symposium, ed., Kraft, 129-130.

${ }^{71}$ Timothy Pickering, Benjamin Lincoln, Beverley Randolph to Henry Knox, Fort Erie, August 21, 1793, in New American State Papers, 1789-1860, Cochran, ed., 4: 144.

72 Heckewelder, July 31, 1793, in Wallace, ed., Travels of Heckewelder, 316. The term "foolish young men" was a metaphorical reference to those considered militant dissenters. The 
Devil, who feared neither the "big Knifes, nor the English." He condemned the peace talks and the Indian leaders who leaned toward appeasing American territorial demands. ${ }^{73}$

Delawares were desperate to reestablish the pre-McIntosh Treaty boundaries. The Stockbridge Mohican known as Captain Hendrick Aupaumut contended that many Delawares were uneasy in the Sandusky/Miami region and "anxious to get back to the waters running into the Ohio," where the "head of those waters afford the best-hunting grounds." ${ }^{74}$ Waiting for diplomacy to settle the boundary dispute, many Delawares were in a "starving condition" and were surviving by eating their dogs and milk cows. ${ }^{75}$ Other Delawares took sanction in the polyglot Indian towns of the Auglaize River region. This was not the new homeland to the Delawares, but rather a temporary military-political stronghold for confederation Indians.

Most importantly, this was evidence that the collective identity of the Delaware nation was being subsumed by the confederation. The Glaize community comprised seven major Indian towns--three of which were Blue Jacket's Shawnees and the "Mingos of the Glaize," who also lived within the Shawnee towns. Also comprising the Glaize were two Delaware towns under the leadership of Buckongahelas and The Big Cat, the Miami town of Little Turtle, and a town for French and British traders. This was a multi-cultural region of Indians, British traders, mixedbloods, and Anglo and Negro captives. The Big Cat and his family lived in a bark-roofed cabin with John Brickell, their adopted white son. ${ }^{76}$ The Grand Glaize towns became the center of Indian

four men who visited Heckewelder, however, may have been peace advocates and definitely out of step with the consensus in the Great Council who favored a military solution.

${ }^{73}$ Heckewelder, Aug. 8, 1793, in ibid., 319.

${ }^{74}$ Captain Hendrick Aupaumut to Commissioner Timothy Pickering, 1793, in "Narrative of John Brickell's Captivity Among the Delaware Indians," The American Pioneer: A Monthly Periodical 2 vols. (Cincinnati, Ohio: Edited and Published by John S. Williams, 1844), 2: 46. ${ }^{75}$ John Brickell in ibid., 2: 53.

${ }^{76}$ Helen Hornbeck Tanner, "The Glaize in 1792: A Composite Indian Community," Ethnohistory 25 (Winter 1978): 16-17. This Indian region, located fifty miles southwest of current-day Toledo, Ohio was torched during Harmar's incursion into Indian country in 1790. A new series of towns were relocated further south in 1792. For a descriptive narrative of John Brickell's life with The Big Cat and the Delawares see "Narrative of John Brickell's Captivity Among the Delaware," 43-56. Brickell was an adopted captive of The Big Cat from 1791-1795. He returned to white society after Wayne's military victory at Fallen Timbers in 1794. 
political and military power in the Northwest and of course, the continued target of the United States military.

Indians remained adamant in their demands that the Ohio River be the boundary line between Indian territory and white settlement. ${ }^{77}$ American commissioners withdrew their demands for the entire Northwest. They agreed that the Indians retained certain territorial rights and boundaries in the Northwest, excluding tracts west of the Ohio ceded by past treaties. They assured the Indians that Congress would pay a "generous compensation; not only for a large sum to be paid at once, but for a yearly rent for the benefit of yourselves and your children forever." The commissioners, however, remained rigid about the main issue. They flatly stated: "We have explicitly declared to you that we cannot now make the Ohio River the boundary between us." 78 The commissioners confronted the Delawares who objected to the land concessions made at Fort McIntosh, and asked them why they had "never heard complaints" regarding past concessions made in western Pennsylvania. ${ }^{79}$ Delawares argued that those treaties had been signed under duress and "through fear"--in essence under pressure. Chiefs, seeking a peace treaty were "obliged to sign any paper that was laid before them." ${ }^{80}$ Sawaughdawunk, a chief of the Wyandots, exemplified the obstinate stance of the tribes on the boundary-line issue. He reminded Commissioner Timothy Pickering that "Many years ago, we all know, that the Ohio was made the boundary. It was settled by Sir William Johnson. This side is ours; we look upon it as our property." 81 The planned council on the Lower Sandusky was squelched by the unyielding positions for a geographic boundary (the Ohio River) to partition the two races. This line meant sanction and security for the western Indian nations. For Americans, it meant territorial restraint-

${ }^{77}$ Reginald Horsman, "The British Indian Department and The Abortive Treaty of Lower Sandusky, 1793," The Ohio Historical Quarterly 52 (July 1961): 184-190.

${ }^{78}$ United States commissioners to the Council of the Northwestern Indian Confederation, Miami Rapids, July 31, 1793, in Cruikshank, ed., Correspondence of Simcoe, 1: 407-408; Horsman, "Abortive Treaty of Lower Sandusky," 205.

${ }^{79}$ United States commissioners to the Northwestern Indian Confederation Council, Miami Rapids, July 31, 1793, in Cruikshank, ed., Correspondence of Simcoe, 1: 407.

${ }^{80}$ Council of the Northwestern Indian Confederation to United States commissioners, Miami Rapids, August 13, 1793, in ibid., 2: 18.

81 Sawaughdawunk to Pickering, Miami Rapids, August 1, 1793, in New American State Papers, 1789-1860, Cochran, ed., 4:137. 
-unacceptable as policy. Washington reluctantly authorized Wayne to launch an offensive against the allied tribes on the Glaize. ${ }^{82}$

The Northwestern Confederation received encouragement from many interested parties to stand against the territorial desires of the United States. In May of 1794, a group of Delawares who were living in Spanish Louisiana (Missouri country) passed on a message from Spanish officials to deputies of the confederation. The Spanish reminded the "Grand Fathers the Delawares" and the other nations of the Glaize, that the Americans "have too long disturbed [your] Country and have extinguished many of [your] Council Fires. ..." The Spanish were confident that the united Indian nations could defeat Wayne's army. ${ }^{83}$

The Spanish also conveyed a message of encouragement from the Creeks, Cherokees, Choctaws, and Chickasaws of the southeast. They reminded the Indians to remain strong and united and that "their Hearts are joined to ours, and that there are eleven Nations of Southern Indians now on their feet, with Hatchet now in their Hands ready to strike" the Americans. ${ }^{84}$ Lastly, the 1,500 to 2,000 warriors who amassed at the Glaize were offered support by the first Governor of Upper Canada John Simcoe, known as the "Great Man of Canada" who urged them “to go \& take the first Fort after another \& overturn General Wayne's army and roll them into the Ohio." 85 Simcoe, especially sympathized with the plight of the Delawares, a people "having already driven from their homes, may be considered as migratory Tribes." He maintained that if

${ }^{82}$ Knox to Wayne, War Department, Jan. 5, 1792, in Knopf, ed., Anthony Wayne, A Name In Arms, 165.

${ }^{83}$ Speeches of the Western Indians at the Miami Rapids, May 7, 1794, in Cruikshank, ed., Correspondence of Simcoe, 2: 231.

${ }^{84}$ Ibid., 2: 32.

85 Simcoe to confederation at Miami Rapids, July 28, 1794, in Erminie Wheeler-Voegelin, Indians of Ohio and Indiana Prior to 1795: Ethnohistory of Indian Use and Occupancy in Ohio and Indiana Prior to 1795 (New York: Garland Publishing Inc., 1974), 295. The agenda of British frontier diplomacy from 1791-1795 was to create a neutral Indian buffer state within the boundaries of the United States. They hoped that this buffer state would shut off American access to the Great Lakes and St. Lawrence region, thus securing Canada from attack. See Samuel Flagg Bemis, Jay's Treaty: A Study in Commerce and Diplomacy (New York: The Macmillan Company, 1924), 109-110. The idea of an envisioned Indian buffer state was not a sentiment unique to British thinking. In 1778, American commissioners at Fort Pitt embraced the same concept, when they promised the Delawares that Ohio would be an Indian state. 
the Delawares moved at the whims of the United States, they "would be totally at the mercy of that People." 86

In August of 1794, Wayne led his well-equipped and well-trained army of three thousand into the Glaize. His last-minute peace overtures were not answered. On August 20, Wayne's army, known as "The Legion," supported by detachments of dragoons and artillery, advanced into the Maumee Valley. Confederation Indians led by Blue Jacket, Buckongahelas, Little Turtle and Little Otter, Egushawa, and Turkey Foot of the Ottawas, attacked the Legion at the Indian stronghold known as the Fallen Timbers (current-day Toledo, Ohio) on the western shore of Lake Erie in the northern part of Ohio Territory. Wayne quickly repelled the Indian attack, countercharged the warriors with fixed bayonets, forced them "into the open," and turned defeat into victory. ${ }^{87}$ As the Indians suffered defeat, many sought sanction at the British outpost of Fort Miami--they were turned away. Buckongahelas took insult when the gates of the fort slammed shut in the faces of his Delaware warriors. Joseph Brant commented that "when the time came the gates were shut against them" as they would do to their enemies. ${ }^{88}$ An Ottawa chief named Kinjoino remarked that "We could not stand against the sharp end of their guns and we ran to the river, swamps, thickets, and to the islands. . . . Our moccasins trickled blood in the

86 Simcoe to Lord Dorchester, York, November 10, 1793, in Cruikshank, ed., Correspondence of Simcoe, 2: 101. Simcoe had visited the Glaize region to encourage the tribes to stand firm. However at the same time, the British Cabinet was pushing to ratify Jay's Treaty and with it, the final evacuation of British outposts in the Northwest Territory. By July of 1794, the British started to back off the prospects of giving military support to the Northwestern Indians. The United States Congress ratified Jay's Treaty on June 24, 1795. See Randolph C. Downes, Frontier Ohio, 1788-1803 in Ohio Historical Collections Vol. III (Columbus: The Ohio State Archaeological and Historical Society, 1935), 39-42.

87 Carter, "Nationbuilding and the Military," 336-337; Sword, President Washington's Indian War, 300-304; Tanner, ed., Atlas of Great Lakes Indian History, 69, 72-73, 78, 87, 91. The Indians referred to Wayne's Legion as the "Whirlwind" (in admiration of its fast movement). See Carter, "Nationbuilding and the Military," 336.

88 Joseph Brant in American State Papers: Indian Affairs, 1: 495. 
sand. Many of our braves were killed in the river." ${ }^{89}$ The army then went to the deserted Indian towns and laid waste to villages and cornfields for fifty miles along the Miami River. ${ }^{90}$

The Indian losses at Fallen Timbers were minimal (fifty killed). The Indians may have fought on, but they suffered a psychological blow. The Legion came within pistol shot of Fort Miami and the British guns remained silent. Once again as demonstrated in the aftermath of the American Revolution, the British had deserted the Indian cause. ${ }^{91}$ Individual Indian nations were left to fend for themselves.

In the spring of 1795 Joseph Brant lamented that the Indians were "in much confusionowing to their late bad Success and in bad Temper by not receiving any assistance from the English." ${ }^{92}$ There was dissension within the Indian ranks. Delawares disclosed, at a later date, that Indian unity did not hold together at Fallen Timbers. They remarked that they, the Shawnees, and Wyandots would always stand their ground and fight, while tribes such as the Chippewas and Ottawas "always ran off when hard pressed, leaving them to bear the brunt of battle...." 93

The Northwest Confederation was broken, but not shattered beyond repair. It resurrected itself once again under the pan-Indianism of the Shawnee leaders, Tenskwatawaw (the Prophet) and Tecumseh in 1811. In the aftermath of Fallen Timbers, however, Indians within the confederation were in a confused state. Many scattered bands of Delawares and Chippewas from the Glaize arrived at the Moravian Christian-Indian town of Fairfield in Canada to seek refuge. David Zeisberger believed that other Delawares "fully intended" to leave the Northwest and "flee to the south and New Spain" [Louisiana Territory]. Others were prepared to meet with Americans and to remain in whatever piece of Ohio country that the United States would permit.

${ }^{89}$ Dresden W. H. Howard, “The Battle of Fallen Timbers as Told by Chief Kin-Jo-INo," Northwest Ohio Quarterly (20): 47.

${ }^{90}$ Wayne to Knox, Head Quarters on the Grand Glaize River, August 28, 1794, in Knopf, ed., Anthony Wayne, A Name In Arms, 354-355.

91 Downes, Frontier Ohio, 45-46.

92 Joseph Brant to Josph Chew, Brownstown, May 20, 1795, in Cruikshank, ed., Correspondence of Simcoe, 3: 78, 96, 98.

93 Comments of Delawares passed to John Johnston who conveyed them to Lyman C. Draper, August 21, 1847, in John Sugden, Blue Jacket: Warrior of the Shawnees (Lincoln: University of Nebraska Press, 2000), 122. 
And yet the Delawares had not reached a council consensus on a destination for a new homeland. ${ }^{94}$ Delawares became bitter at the geopolitical realities that once again emerged to threaten their nation--as scattered as it was. In the Great Council of the Lupwaaeenoawuk, warriors rose to spew vehement rhetoric against the British who had once again abandoned them to the United States. They vented in the council houses:

Thou hast always hitherto urged us to go to war against the States. We have followed thee to our great loss. Look at the graves on the Miami, look further on, where the bones of the young folk lie. ... Thou art the cause of their death. We will no longer be deceived by thee. ${ }^{95}$

The American victory for the Northwest left the Delawares in a confused and uncertain state. Some of the Ontario Delawares wished to make peace, while other bands wished to fight on. Some Delawares were not pleased that the Moravian missionaries had arrived on the Thames, others wanted to reestablish the Christian William Henry (Killbuck) as chief of the nation. ${ }^{96}$ Remnant Ohio Delawares of the Glaize towns went to the peace talks at Greenville to meet with Anthony Wayne and American officials and to learn their fate. At Greenville in 1795, Tetapachksit, the "Grand Glaize King" of the Delawares and the aging Little Turtle of the Miamis wanted to negotiate directly with General Wayne. Joseph Brant of the Six Nations entered into the picture, despite the fact that he and the Iroquois did not offer military support for the confederation at Fallen Timbers. Brant took the role of chief spokesman for the Indians. ${ }^{97}$ He tried to exploit the weakened state of the defeated Indian nations and the power vacuum created in Indian leadership by 1795 . The young warriors no longer respected Little Turtle, who desired peace before Fallen Timbers. The fearless Blue Jacket of the Shawnees lacked the wisdom

94 Entry of Zeisberger, October 15, 1794, in Bliss, ed., Diary of David Zeisberger, 2: 378.

95 Delaware speaker to British delegation, October 15, 1794, in ibid., 2: 378.

${ }^{96}$ Entry of Zeisberger, October 11, 1794, in ibid., 2: 378.

97 Sword, President Washington's Indian War, 291, 297, 312-313; Allan W. Eckert, A Sorrow in Our Heart: The Life of Tecumseh (New York: Bantam Books, 1992), 561. 
and statesmanship of Little Turtle. Little Otter of the Ottawas was killed and another war leader, Egushawa was severely wounded at Fallen Timbers. ${ }^{98}$

The Delawares and Wyandots deplored Brant's play for political dominance. To gain the support of the Delawares, Brant acknowledged that the Delawares were once again men in the eyes of the Six Nations. In a ceremony, Brant literally removed the petticoat from a young man and in its place, “shorn [the] Indian's head, leaving only a little hair at the top, adorned him with white feathers, as the warriors are accustomed to do, and painted him." He took from the Indian the "grubbing axe and [corn] pestle," [the tools of a woman] and replaced them with a breechclout and war hatchet. It was noted by David Zeisberger that Brant "made the Delaware nation not only into men, but into warriors." 99

This was a latent and hollow gesture by Brant and the Six Nations, who were attempting to assert influence in the Northwest region. The Delawares were not moved by Brant's diplomatic ploy. They remembered that Sir William Johnson had removed the petticoat from them over thirty years earlier and that White Eyes had established their independence from Onondaga before the American Revolution. Despite the fractured state of the Delaware nation, the defiance towards Iroquois attempts of suppression remained. The Delawares, brushing aside Brant's declaration and demonstrating their disdain for the Six Nations who failed to support them against the American military, remarked: "Peace shall be made [with Wayne]. What use have we for the deadly musket in our house? We have no use for it, except we use it against our uncles, who have already often deserved it of us." 100

98 Sword, President Washington's Indian War, 291, 297, 312-313.

99 Entry of Zeisberger, June 15, 1795, in Bliss, ed., Diary of David Zeisberger, 2: 409410. According to Isabel Thompson Kelsay, Brant realized he had lost influence among the Delawares and western nations. He decided not to go to the Greenville Treaty talks See Kelsay, Joseph Brant, 518.

${ }^{100}$ Ibid., 410. Zeisberger believed that Brant and the Canadian Mohawks were instigating the Delawares into continuing the fight against the United States. When they refused to fight, it was purported that Brant sent three war belts to the Chippewas to "urge them to war against the Delawares . . . to make broth thereof." Both Brant and the Six Nations denied that they were instigating animosities in the Northwest. See Entries of Zeisberger, August 16-22, 1795 and April 28, 1796, in Bliss, ed., Diary of David Zeisberger, 2: 416-418, 445. 
The treaty talks at Greenville began on June 16, 1795. Over 1,100 confederation Indians of the Delaware, Wyandot, Shawnee, Ottawa, Chippewa, Potawatomi, Miami, Kickapoo and Piankashaw nations met with Wayne and American commissioners to determine boundaries, land cessions, and proper annuity payments. Over 381 Delawares, the most from any nation, attended. Principal leaders among the Delawares included the Turtle leader Tetapachksit, Buckongahelas and Hockingpomska ("Hard Walker”), representatives of the Wolf tribe, and Kikthawenund (William Anderson), who headed the Turkey division. ${ }^{101}$ Other Delaware leaders included Lemantanquis (Black King), Maghpiway (Red Feather), Peekeelund, Kishkopekund (Captain Buffalo), Amenahehan (Captain Crow), and Queshawksey (George Washington). ${ }^{102}$ These leaders represented both the old and the new within the Great Council.

Despite the large number of Delaware leaders in attendance, the new headmen within the Lupwaaeenoawuk lacked the vision and skill to reconstruct the nation. A definitive feature in national development was the leadership of such men as White Eyes, Tamaqua, and Pisquetomen. There were no such leaders at Greenville. The compliant and elderly Tetapachksit was recognized by the United States as the main Delaware chief, and by Buckongahelas as "our King." 103 The Delawares acknowledged that they, as a defeated nation, had to be more accommodating to American demands. Confederation concerns were no longer considered as relevant to the Delawares--attainment of an Ohio homeland and a reunited nation were no longer a possibility.

The treaty was signed on August 3, after months of negotiations. The federated Indian nations agreed to cede to the United States the southern and northeastern part of the Northwest Territory. The United States was also given access to key rivers (the headwaters of the Wabash and Auglaize, to name a few) and principal portages "adjoining the Indian lands" and given free

101 Weslager, The Delaware Indian Migration, 51.

102 Delaware signatures on the Treaty Of Greenville, August 3, 1795, in Territorial Papers of the United States, ed., Carter, Northwest 2: 531-533; Indian Affairs: Laws and Treaties, Kappler, ed., 2: 44.

103 Buckongahelas to United States commissioners at Greenville, August 7, 1795, in New American State Papers, 1789-1860, ed., Cochran, 4: 176. 
passage through Indian country, when "found convenient." ${ }^{104}$ Article V of the treaty acknowledged the Indians' rights to certain areas for hunting and settlement. ${ }^{105}$ Any hopes that the Ohio River would remain as a boundary between Indians and the United States were squelched forever. Buckongahelas, humbled by defeat and reduced in stature by United States officials during the negotiations, offered the sentiments of the Lupwaaeenoawuk and the Delaware nation: "All who know me, know me to be a man and a warrior, and I now declare, that I will, for the future, be as true and steady a friend to the United States as I have heretofore been an active enemy." 106

For the Delawares there was a prophetic finality to Buckongahelas's rhetoric. They would never again, as a nation, take up the hatchet against the United States. They would also suffer continual territorial dislocations and migrations westward. In 1797, Zeisberger noted that the Delaware nation was "scattered at present from Canada to the Mississippi, and their present chief [Tetapachksit] has little weight and authority." 107 John Heckewelder, ever the idyllic promoter of Lenape national eminence and destiny, lamented that at the turn of the nineteenth century Delaware nationhood was "brought down to such a low state;" a once "great and powerful nation" in decline. ${ }^{108}$

In the aftermath of the Indians' defeat at Fallen Timbers and the Greenville peace settlement, the Delawares entered into an era of uncertainty and instability. Most importantly, a strong national unity or consensus became even more difficult to attain as Delaware bands moved to the new frontiers of the United States and the safe havens of Canada.

104 Dwight L. Smith, "Wayne's Peace With the Indians of the Old Northwest, 1795," The Ohio State Archaeological and Historical Quarterly 59 (1950): 253-254; Article III of Treaty of Greenville, August 3, 1795, in Indian Affairs: Laws and Treaties, Kappler, ed. 2: 41; Tanner, ed., Atlas of Great Lakes Indian History, 155.

105 Article V of Treaty of Greenville, August 3, 1795, in Indian Affairs: Laws and Treaties, Kappler, ed. 2: 42.

106 Buckongahelas to United States commissioners at Greenville, September 20, 1795, in New American State Papers, 1789-1860, ed., Cochran, 4: 176.

${ }^{107}$ Entry of Zeisberger, November 11, 1797, in Bliss, ed., Diary of David Zeisberger, 2: 502.

108 Heckewelder to Dr. Wister, Bethehem, March 24, 1811, in Heckewelder, An Account of the Indian Nations, 357. 
The post-Revolutionary Delaware nation was in a state of flux. Factionalism in the Great Council, the lack of a strong leader with vision, and a disastrous Indian war suspended national development. Delaware unity and a sense of direction were sacrificed to participate in the panIndian alliance of the Northwest Confederation. Most importantly, the homeland of the Ohio country, the region that spawned the growth of a Delaware nation, was now a memory.

Despite the weakened and dispersed state of the nation, Delawares pondered their future as a nation. They embraced a hope--enhanced by their resilient nature as they entered a new century. This quality could be found in a Delaware prayer that acknowledged:

We belong unto a nation

Which now shattered, wrecked, and severed, Still belongs to the Great Spirit, Who announces us His own, And has pointed out a highway We may travel to his realm, And for this we're very thankful. ${ }^{109}$

By the early 1800 s, the Delaware nation was adrift, diplomatically and militarily unable to stop the advances of American expansion. Fragments of the Delaware nation moved west, once again in search of new thresholds, referred to by the Delawares as "Kwulakan."

109 "Thanksgiving Oration of the Delawares" in Richard C. Adams, The Ancient Religion of the Delaware Indians and Observations and Reflections (Washington, D. C.: The Law Reporter Printing Co., 1904), 24 


\section{Conclusion}

For the Turtle, Turkey, and Wolf tribes of Delaware Indians, the common self-interests and similar challenges which resulted in nation building derived from the struggle for political autonomy and union and for the defense of a new homeland. From 1730 to 1795, the Delaware Indian nation slowly emerged and reached the apex of development, only to undergo a fragmentation and quick decline.

Much of this national construction was the result of shared historical experiences. The detrimental consequences of the Iroquois/Pennsylvania alliance of the early 1730s and European settlement stifled Delaware independence among all the Delaware bands and served as a contributing factor in the Delaware westward exodus--a migration that both accelerated the process of a national identity and the need for a more centralized structure of leadership. The Turtle, Turkey, and Wolf tribes moved from their traditional homes in the Delaware and Susquehanna river valleys to adopt a new regional homeland, first in the Allegheny and Beaver valleys of western Pennsylvania, and then further west in the Muskingum Valley of Ohio.

The western migration into these regions enhanced the sense of ethnic commonality and eventual political cohesion among the phratries. Leaders such as Shingas, Tamaqua, Pisquetomen, and Custaloga epitomized strong leadership on a local level. At the same time, these phratry loyalties contributed to a growing collective Delaware identity. These were innovative leaders who gained influence and prominence as the voice of western Delawares. These leaders had the diplomatic skill to veer the Delawares away from the subservient position that had been established for them by the Covenant Chain, without destroying their ties with the British. The appearance of these important leaders at places such as Kittanning, Shannopin's Town, and the Kuskuskies, combined with deference to phratry strength, was crucial to national progress.

Delawares, who finally resided in the western reaches of Ohio country, were comprised of two distinct entities, one being the Turtle-Turkey coalition of Unami speakers, the other being the Wolf contingent of Munsee speakers. Eventually, when the historical circumstances of the Seven Years' War threatened the new homeland, western Delawares politically organized to create a more unified and centralized structure. The Delaware animal tribes fused together as a tribal nation by 1765 . This is particularly evident during the negotiations of the phratry leaders 
with Colonel Bouquet and Sir William Johnson in the aftermath of Pontiac's uprising. Despite the lure of pan-Indian movements, the course of Delaware nationhood remained uninterrupted.

In this process of national development, the Great Council of the Lupwaaeenoawuk served as the lifeblood of national polity and helped to solidify the uniting of the three tribes. Delaware bands and tribes eventually embraced a common vision of nation--a political entity, nationalized in the Great Council House at Goschachgunk, structured in time of crisis to counter Anglo-American power and aggression during the later part of the eighteenth century. In this sense, the frontier expansion of British America intensified the Delaware the urgency for unification and centralization and thus forced Anglo-Americans to take notice and respond accordingly.

The Delaware nation, however, was forged in tension. While contact with EuroAmericans spurred the call for Delawares to construct a political nation, this same contact also created the factions that slowly destroyed any chance of a permanent and stable nation. Delawares did not have the maturation, historical reference, or time to work out the snags in the centralized structure. Delawares, despite the attempts of the civil leader White Eyes to lead a pro-American nation and Moravian missionaries to guide the nation into a neutral stance, became strongly polarized in the Great Council and could not escape military involvement in America's war for independence. Paradoxically, the political forum, that was a definitive feature of a functioning political nation, pulled Delawares, in need of centralization, apart.

In its theoretical context, nationhood was a result of an adjustment or adaptation made by Indians in times of uncertainty. It was never a completed process. John Moore notes that the Cheyenne nation comprised a collection of migrating Algonkian-speaking bands or " bunches." Upon their entrance to the Great Plains in the early nineteenth century, these groups, to protect and strenghthen themselves from neighboring Indian nations, pressed for social and political consolidation. Most importantly, despite the attempt of Cheyennes to unify, full integration and homogenization was "never completely successful" as political strife always existed. As an example, the peace and war factions of the Cheyennes steadily clashed for dominance in national policy. When immigrants, soldiers, and miners poured into Cheyenne country after the $1850 \mathrm{~s}$, Cheyenne society underwent drastic change. Cheyennes became locked in continual conflict with the United States. The equilibrium that had traditionally existed 
between the civil and military was shattered. The peace or civil chiefs were swept to the side and the war leaders and military societies emerged as the national voice of the Cheyennes. ${ }^{1}$

Moore's analogy could be readily applied to the Delawares during the American Revolution. At that time, Delawares struggled with factionalism as they tried to maintain neutrality. Captain Pipe, a Wolf leader, opposed the Pro-American leanings of White Eyes in the Great Council of the Delawares. In frustration, Captain Pipe and his Wolf tribe seceded from the Delaware council fires. This schism was only temporary, but it demonstrated a fragile tribal union during a time of crisis when Delawares in the Ohio strove to achieve peace and hold on to their national homeland on the Muskingum River. According to Moore, Cheyenne factionalism, despite its moments of disruption, reflected positive development and the even temperament among leaders to work out and maintain a consensus on a national level. However, the Delaware story is much different. The chasm between the Unami and Munsee contingents in the Great Council demonstrated that consensus, through tempered diplomatic persuasion and debate, was a fleeting ideal. In a time of crisis, there was now an intense power struggle between two important leaders who advocated two different directions--a dangerous dilemma for a struggling nation.

For the most part, the cohesiveness and vitality of a unified nation was short-lived. The stress of a major war broke apart the fragile political unity that had been a continuous struggle for the Turtle, Turkey, and Wolf tribes to achieve. Without the anchoring guidance of White Eyes, the Delawares were vulnerable to the machinations of the British and the militant goading of the allied western Indian nations. Most importantly, the Wolf division gained preeminence over the Unamis as the makers of policy. By 1780 and into the mid 1790s, the war policies of Captain Pipe and Buckongahelas of the Wolf division swayed the Lupwaaeenoawuk down a devastating course. The Gnadenhutten Massacre of 1782 broke the back of the Delawares and forever ended a close, or at least trusting, relationship with the United States. In 1785, Pipe and a minority

${ }^{1}$ Moore, The Cheyenne Nation, 24-25. In this time of national crisis, Cheyenne social organization was also transformed from a matrilineal to a paternal society. Moore emphasizes that the Cheyennes were not a "stable, tightly integrated society dominated by council chiefs." Rather than adhering to the traditional forms of social organization (uterine based-- after marriage, a young man moved into his wife's band), many Cheyennes became agnatic (to insure warrior strength and cohesion within a band, the wife lived with her husband's band). Moore maintains that the tension grew between the uterine and agnatic factions as Cheyennes argued with regards to peace treaties or warfare as a solution to their problems with the western expansion of the United States. 
Wolf faction went against the grain of council consensus and attempted to appease Americans by signing away more Delaware land during the treaty talks at Fort McIntosh.

After 1795, the Indian defeat at Fallen Timbers and the land cessions of the Greenville Treaty weakened the Delaware nation at a time when strength was needed to stop American territorial expansion. Buckongahelas and Tetapachksit's days were numbered. New leaders lacked the spirit, will, and diplomatic sway to repel future territorial demands of the United States. Delawares moved piecemeal further west to Missouri, Kansas, north to Wisconsin, and into Canada. Like many Indian nations east of the Mississippi, the Delawares no longer exerted the military and political presence and influence they had enjoyed during the Seven Years' War and American Revolution.

There is not an uplifting ending to the story of the emergence of the Delaware nation. Its history, in essence, is typical of the Native American experience during the colonial and expansionist eras of America. It is a story of futile adaptations in the face of overwhelming odds. Many Indian nations and tribes underwent great transformation to counter the territorial designs of the Anglo world--a form of political or cultural modification to counter a massive racial invasion. Some, such as the Iroquois Confederation, expanded their military and diplomatic reach to gain a long-standing preeminence in the colonial Indian world. The Seneca nation of the Iroquois Confederation suffered decline and then a spiritual rebirth, through the Handsome Lake religion. Others such as the Susquehannocks of central Pennsylvania and the Huron Confederation of the Great Lakes were overwhelmed by European invasion, chronic military conflict, and disease and were thus obliterated--their names swept from the continent. Still others, such as the three tribes of Delawares, gravitated around their cultural and ethnic commonalities and united under a national structure. They created a new, though tenuous, political order.

This nation slowly evolved throughout the eighteenth century and yet rapidly fell apart. By the 1800s, the Delawares were sapped of military and diplomatic strength and a homeland. The Delaware development of nation demonstrates the irony of history. While Delaware western migration during the eighteenth century served as the means for building a nation, relocation during the nineteenth century had the opposite result. One migration can be seen as seeking a renewal and revigoration, the later represents a flight from the continual territorial and cultural 
assaults by the United States. During the nineteenth century, the Delaware nation became further diluted, as the various bands moved sporadically in many different directions throughout North America. The Delawares became displaced wanderers and unwanted refugees as they moved west to the prairies and plains. Other Indian tribes and nations west of the Mississippi had yet to face the fate of the Lenape and Munsee people, collectively known as the Delaware nation. 


\section{Epilogue-- The Delaware Migrations Continue}

At the turn of the nineteenth century, bands of Delawares, along with Shawnees, and Wyandots were restricted to the northwestern section of Ohio and the St. Mary's and St. Joseph's region of Indiana. ${ }^{1}$ American settlers quickly breached the Greenville Treaty boundary line, particularly the western boundary. Delaware leaders asked the United States government to "have a great road Cut that it may prevent the White people from Settling on their hunting grounds...." 2 The Delaware nation was wracked by territorial dislocation, political factionalism, and geographical fragmentation. Once again the Delawares became migrants and wanderers, in search of a new homeland and desperate to reunify the nation.

From 1801 to 1808 , the main body of the Delawares, at the invitation of the Miamis and Potawatomis, relocated to a series of towns on the west fork of the White River (between current-day Muncie and Indianapolis) deeper into Indiana Territory. Buckongahelas's followers lived at Wapicomemoke in the eastern region, while Chief Anderson lived to the west at Wapeminskink, known by the Indians as the "chestnut tree place." Other major Delaware towns along the White River included Tetapachksit's Town and Hockingpomska's Town. ${ }^{3}$

Buckongahelas, recognized by most Delawares as the "leading person in the Council," worked closely with Tetapachksit in the attempts to "cement [the] nation more closely together" during those uncertain times. In an old strategy to gain stability and unification, the Delaware council invited the Moravians to establish missions among their people on the White River. This

1 Hurt, The Ohio Frontier, 315.

2 Surveyor General of the United States, Rufus Putnam to Oliver Wolcott, Secretary of Treasury, Philadelphia, March 15, 1799, in Territorial Papers of the United States, ed., Carter, Northwest 3: 18.

3 Weslager, The Delaware Indians, 333-335; Lawrence Henry Gipson, ed., The Moravian Indian Mission on White River: Diaries and Letters, May 5, 1799, to November 12, 1806 (Indianapolis: Indiana Historical Bureau, 1938), 107-108; Tanner, ed., Atlas of Great Lakes Indian History, 98; Gayle Thornbrough, ed., Letter Book of the Indian Agency at Fort Wayne, 1809-1815 (Indianapolis: Indiana Historical Society, 1961), 53-54. Under the treaty stipulations at Greenville, confederation Indians were given extensive hunting rights to land north across Ohio and south and west of the Great Lakes as far as the Mississippi River. See Weslager, The Delaware Indians, 330. 
time, the missionaries were not permitted to attend council meetings. The Moravians were brought back only to help strengthen a relocated Delaware society, not for political input. ${ }^{4}$

While the Delawares attempted to build stable communities on the White River, President Thomas Jefferson became eager to open up new territories to fulfill his vision of an agrarian America. He instructed territorial governor William Henry Harrison to gain more land cessions from the nations of the Northwest. Harrison targeted, through forceful negotiations, the lands surrounding the Wabash River. ${ }^{5}$ On August 18, 1804 at Vincennes, Tetapachksit, Buckongahelas, and Hockingpomska, together with principal leaders of the Piankashaws, ceded their claims to a "tract of country between the Ohio and the Wabash rivers," which included a large section of southern Indiana. 6

This treaty was not well received by the confederated tribes, who once again argued that individual nations could not cede land without the consent of all. At this time, the anti-American rhetoric of the Shawnee leader, Tenskwatawa (the Prophet) and his followers located in multitribal towns at Tippecanoe on the upper Wabash, reached the Delaware towns on the White River. Traditionalists who favored the pan-Indianism of Tenskwatawa and his brother, Tecumseh, turned on the signers of the Vincennes Treaty. Because of their agreement with Americans, the ancient Tetapachksit and the once revered Buckongahelas fell out of favor among the Delaware people. Buckongahelas died in 1805 and those Delawares who followed the

4 John Kluge and Abraham Luckenbach, Goshen Mission, April 1800, in Gipson, ed., Moravian Indian Mission, 32-33; Weslager, The Delaware Indians, 336-337.

5 Anthony F. C. Wallace, Jefferson and the Indians: The Tragic Fate of the First Americans (Cambridge, Massachusetts: The Belknap Press of Harvard University, 1999), 317; Hurt, The Ohio Frontier, 316. For an intellectual rationalization on Jefferson's Indian policy see Bernard W. Sheehan, Seeds of Extinction: Jeffersonian Philanthropy and the American Indians (Chapel Hill: University of North Carolina Press, 1973). For a well thought work on Jefferon's ideology and how it was applied to American Indians see Bernard W. Sheehan, Seeds of Extinction: Jeffersonian Philanthropy and the American Indians Chapel Hill: University of North Carolina Press, 1973.

6 President Thomas Jefferson to the Senate, Washington, D. C., November 19, 1804, in New American State Papers, 1789-1860: Indian Affairs, Cochran, ed., 4: 181. A small band of pro-American Delawares led by Montgomery Montour wanted to remain in the region ceded by the Delawares. They did not want to resettle among the warlike tribes of the west. The United States gave this band a small tract of land on the Wabash. They remained there for a decade until they were forced to move to Missouri country. See American State Papers, 1832-1861: Indian Affairs, 744; Wallace, Jefferson and the Indians, 284. 
Prophet accused Tetapachksit of performing the witchcraft that caused the death of Buckongahelas. A group of Delawares, one the son of Tetapachksit, seized the chief, tomahawked him and threw him alive into a fire. Billy Patterson, the nephew of Tetepachksit and chief interpreter at Vincennes was also thrown into the fire. Hockingpomska, the third signer, was rescued by a group of Delaware supporters. ${ }^{7}$

The Delaware Great Council weathered the storm of factionalism. Despite the overtures of the Prophet and Tecumseh, only a handful of defiant Delaware warriors fought against the United States military led by William Henry Harrison at the Battle of Tippecanoe in 1811.8 Delawares remained true to Buckongahelas's promise never to fight the Americans. On August 19, 1813 over two hundred warriors led by Chief Anderson, together with Wyandots and Shawnees fought pro-British Potawatomis at the mouth of the Maumee River in Ohio. ${ }^{9}$

In 1818 the Delawares ended their stay in Indiana by signing the Treaty of St. Mary's. Anderson, Big Bear, The Big Cat, Captain Killbuck and Captain White Eyes, the latter two being descendents of the Revolutionary War leaders, ceded all land claims in Indiana and removed west of the Mississippi River to Missouri. The United States government agreed to provide land for

7 Gipson, ed., Moravian Indian Mission, 559; Wallace, Jefferson and the Indians, 232233; White, The Middle Ground, 499; Weslager The Delaware Indians, 343-344; R. David Edmunds, The Shawnee Prophet (Lincoln: University of Nebraska Press, 1983), 44-46 and Gregory E. Dowd, "Thinking and Believing: Nativism and Unity in the Ages of Pontiac and Tecumseh," in Roger L. Nichols, ed., The American Indian: Past and Present (Boston: McGraw Hill, 1999), 89-90. Kikthawenund (William Anderson), a mixed blood of the Turkey division became the principal leader of the Delawares after the murder of Tetapachksit.

8 Weslager The Delaware Indians, 345; Edmunds, The Shawnee Prophet, 104-115. At the Battle of Tippecanoe in November of 1811, the Prophet who was the religious leader of the confederated nations, attacked Harrison's army while peace negotiations were still in process. Harrison overcame the surprise attack to route the warriors of the Prophet. Tecumseh, the war leader and military strategist, was on a recruiting junket trying to encourage the southern nations of the Creeks and Cherokees to join the Northwestern nations against the United States. The Prophet lost much of his status as a leader after this defeat--Tecumseh increased his following among the revivalists. American forces at the Battle of the Thames in Ontario killed Tecumseh in 1813.

9 R. David Edmunds, “"A Watchful Safeguard to our Habitations': Black Hoof and the Loyal Shawnees," in Frederick E. Hoxie et al., ed., Native Americans and the Early Republic (Charlottesville: The University Press of Virginia, 1999), 190-191. Tecumseh denounced these Delawares for supporting the "Long Knives" and William Henry Harrison praised the Delawares who had "proven their fidelity in an exemplary manner." See Edmunds, "A Watchful Safeguard to our Habitations,", 192. 
the Delawares and to furnish the boats and horses needed to cross the Mississippi. ${ }^{10}$ John Heckewelder observed that the Delaware nation, particularly the Wolf phratry, was in disarray, with settlements in Canada, Ohio, and "on the waters of the Wabash . . A considerable number of them [have] crossed the Mississippi."11 Other Munsees moved into Wisconsin along with the Stockbridge Mohicans to form a community that exists to this day. ${ }^{12}$ In 1829 , Welsinqua, Billy Montour, and Isaac Hill removed the last remnants of over one hundred and thirty Delawares and Mingos in the Upper Sandusky region of the Ohio. They left to join other Delawares west of the Mississippi. ${ }^{13}$ With regard to the western Delawares, Welsinqua (Captain Pipe) noted that the Ohio Delawares were "desirous of following and uniting ourselves with them, that we might again be one people." 14

By the early 1820 's Indiana and Illinois, for the most part, purged themselves of Indians by removing Delawares, Kickapoos, Ottawas, Chippewas, Potawatomis, Peorias and other tribes westward into the territories of Missouri, Kansas, and Spanish-controlled Texas. Illinois eventually ejected the Sauk and Fox allies, in the aftermath of Black Hawk's War in 1832.15 When Indiana wanted to open the Wabash Valley to white settlement, the Delawares migrated westward on their own initiative. Indian agent and clergyman Jedediah Morse noted, "their peculiar aversion to having white people for neighbors, induced them to remove to the westward." Sadly, he added, that a once "numerous and powerful” Delaware people were reduced to a "mere handful."16

10 Grant Foreman, The Last Trek of the Indians (Chicago: University of Chicago Press, 1946), 37; Wallace, Jefferson and the Indians, 274; Weslager The Delaware Indians, 352.

11 Heckewelder, An Account of The Indian Nations, 68.

12 Jay Miller, "Delaware," in Hoxie, ed., Encyclopedia of North American Indians, 159. Another community of Munsees eventually moved with bands of Ojibwas to Kansas Territory.

13 Treaty between the United States and a "band of Delaware Indians," January 2, 1830, in New American State Papers, 1789-1860: Indian Affairs, Cochran, ed., 4: 204-205, 225-226; Foreman, Last Trek of the Indians, 56. Welsinqua, related to Captain Pipe, inherited the name of the Wolf leader.

14 Welsinqua (Captain Pipe) to President John Quincy Adams, Camp near Upper Sandusky, September 3. 1828, in New American State Papers, 1789-1860: Indian Affairs, Cochran, ed., 4: 204-205.

15 Ibid., 38-44.

16 Jedediah Morse, A Report to the Secretary of War of the United States on Indian Affairs (1822; reprint, New York: Augustus M. Kelley Publishers, 1970), 90. Indiana Delawares 
Their residency in Missouri was both unpleasant and brief. Delawares, with other eastern Indians, moved into the Ozark forests of Osage Indian homeland. Cherokees, Delawares, Shawnees, and Choctaws swelled the region and by April 1824 there were over two thousand of these hunters cutting into most of the regional game, leading to a frustration and "collective rage" among Osage warriors. ${ }^{17}$ In the fall of 1824 Osages stole horses from the Delawares, and in the chase to retake their horses, the Osages killed the son of Delaware Chief Anderson. In a "cycle of revenge killings," Delawares allied themselves with Shawnees and Kickapoos and preyed upon Osage hunters along the Neosho and Verdigris rivers. ${ }^{18}$ Despite a peace council between the eastern tribes and the Osages held in St. Louis in 1826, the violence in Missouri continued until 1827 when a greatly weakened Osage tribe sought a more binding peace. 19

Delawares also suffered economic deprivation in their Missouri homes. In February 1824 Delaware chiefs, Anderson, Black Beaver, and Natcoming addressed William Clark the Superintendent of Indian Affairs, in St. Louis, on the plight of the Delawares:

Last summer a number of our people died just for want of something to live on. We have got in a country where we do not find all as stated to us when we was asked to swap lands with you and we do not get as much as was promised us at the Treaty of St. Mary's. . . . We have found a poor hilly stony country and the worst of all no game to be found on it to live on. ${ }^{20}$

On September 24, 1829, the United States negotiated a new treaty with the Delawares. The Treaty of Council Camp canceled Delaware claims to land in Missouri and allocated them

ferried across the Kaskaskia and Mississippi Rivers to reach James Fork of southwestern Missouri. Foreman reported their population to be 1,346 plus their 1,500 horses. See Foreman, Last Trek of the Indians, 40-42.

17 Willard H. Rollings, The Osage: An Ethnohistorical Study of Hegemony on the PrairiePlains (Columbia: University of Missouri Press, 1992), 250-252.

18 Ibid., 251, 253-263. For more on this animosity between eastern tribes and Osages see Brad Agnew, Fort Gibson: Terminal on the Trail of Tears (Norman: University of Oklahoma Press, 1980) 45-49, 63-64.

19 James B. Christianson, "Early Osage_- "The Ishmaelites of the Savages," Kansas History 11 (Spring 1988), 15-16; Foreman, Last Trek of the Indians, 54-55. 
tracts of land in Kansas Territory, land that had previously been ceded by the Osage and Kansa Indians. Those Delawares and Shawnees who lived together in Cape Girardeau were moved west to reservations on the Kansas River. The remainder of Delawares, who had previously settled in Texas, "were driven back by the Texans to the Choctaw Territory" [Indian Territory]. ${ }^{21}$ Kansas became a Mecca, or as James Merrell contends, an "Indian asylum in the West," for the eastern Indian nations of the government's Removal Policy. ${ }^{22}$ These tribes were given a "band of country nearly fifty miles wide" in eastern and western Kansas. ${ }^{23}$ The Delawares and other dislocated tribes were thrust against the periphery of the American frontier. Residing in this territorial environment of reservations, Delawares became caught between the colliding forces of assimilation policies of the government and the traditionalism of the Great Plains Indian nations to the west.

The Delawares were in a precarious position. The plains and prairies of the 1830 s were regions of competition and struggle among the established regional tribes and immigrant nations. There was a lack of racial cohesion between the eastern immigrant and plains Indians, who were competing for game on the massive bison ranges. ${ }^{24}$ The Delawares in Kansas were besieged by both the pressures of assimilation into white society and negative interaction with the Great Plains Indians.

20 Delaware chiefs to William Clark in Weslager, The Delaware Indians, 364. William Clark was the captain of the famed Lewis and Clark expedition,

21 Office of Indian Affairs, March 2, 1845, in Grant Foreman, Advancing the Frontier, 1830-1860 (Norman: University of Oklahoma Press, 1933), 231-232. These Delawares were eventually moved to Creek Indian Territory in 1845. According to Foreman, the Creeks welcomed them, for their "courage and resourcefulness," but also made them a buffer that protected the Creeks from hostile Plains Indians. These Delaware immigrants helped secure Creek security on the "exposed border," 233. Weslager in Delaware Indian Migration mentioned that at this time, Delawares were a splintered nation. Groups lived on the upper Sandusky River in Ohio, on the Kaskaskia River in Illinois, and a group of Munsee Delawares lived in Wisconsin, 215. In 1854, Texas unsuccessfully attempted to create a reserve on the Brazos River for remnant Delawares, Shawnees, Wichitas, and Caddos. See Weslager, The Delaware Indians, 432.

22 James H. Merrell, "American Nations, Old and New: Reflections on Indians and the Early Republic," in Hoxie ed., Native Americans and the Early Republic, 353.

23 Foreman, Last Trek of the Indians, 51.

24 Colin G. Calloway, "The Inter-tribal Balance of Power on the Great Plains, 17601850," Journal of American Studies 16 (April 1982), 47. 
The Delaware reservation was located on the eastern border of Kansas along the Missouri and Kansas rivers in present day Wyandotte County. The line extended westward to Fort Leavenworth, a total of 924,160 acres. An outlet was added which pushed Delaware land to over 2.8 million acres. ${ }^{25}$ This outlet was ten miles wide and extended from the northwest corner of the Delaware reservation to the bison grounds of the plains, a distance of over 200 miles. ${ }^{26}$

The reservation represented a promised land for the Delawares, a place where they could live without being crowded and pressured by white settlement. On the Delaware reservation, the government constructed a sawmill, gristmill, and a blacksmith shop and supplied them with wagons, tools, and a full year's provisions. ${ }^{27}$ The Delaware Great Council permitted Methodists and Baptists, and eventually Moravians, to build missions on the reservation. 28 The Presbyterian Reverend Samuel Allis entered the Delaware reservation in July of 1835 and saw about "1,000 souls," plus a "Government teacher \& blacksmith." Allis noted that the Delawares raised "some wheat, considerable corn \& vegetables." He saw that their land was rich and offered ample space for their cattle, horses, sheep, and hogs. 29

Delaware leaders hoped for a more stable and peaceful community than they had experienced in Missouri. When Major Clifton Wharton of the 1st Regiment of United States Dragoons met with Otos and Pawnees in 1844, he was asked by Delaware chiefs to deliver a message to the Pawnees who lived to the north of the Delaware reserve: "They desire to be at peace with you. They say that since they had ceased to make War their people lived happily-that they raise plenty of corn for themselves \& cattle-- and they urge you to follow their

25 William Frank Zornow, Kansas: A History of the Jayhawk State (Norman: University of Oklahoma Press, 1957), 44-45; Joab Spencer, "The Shawnee Indians: Their Customs, Traditions and Folk-Lore," Transactions of the Kansas State Historical Society 10 (1907-1908), 382.

26 John C. McCoy, "Survey Of Kansas Indian Lands," Transactions of the Kansas State Historical Society 4 (1886-1888), 304.

27 Weslager, Delaware Indian Migration, 220-221; Weslager, The Delaware Indians, 369.

28 Reverend William Patton, May 10, 1843, in "Letters From the Indian Missions in Kansas," Transactions of the Kansas State Historical Society 16 (1923-1925), 258.

29 Samuel Allis to Rev. David Greene in Waldo Wedel, ed., The Dunbar-Allis Letters on the Pawnee (New York: Garland Publishing, Inc., 1985), 693. 
example." Wharton then added that he knew how happy the Delawares were. He stated:

"Pawnees, imitate them and you will be happy and prosperous also." 30

The dismembered Delaware nation was not in the happy state that many had hoped for. Negative experiences awaited Delawares when they came in contact with the Indians to the west. When Delawares lived in Missouri, their energetic young hunters chased the bison on the Great Plains. This brought them in contact with Indian hunters who resented competitors for the rich gaming herds of the Plains. Delaware hunters were constantly ambushed and "according to their custom" and conceptions of manhood, they retaliated as a way to save face. ${ }^{31}$

The Delawares and other immigrant tribes were seen by the Great Plains Indian nations as "a race between the whites, and their own Indian people." 32 As a migratory tribe, new to the plains, they hunted through the outlet between the Platte and Kansas rivers. The Pawnees dominated this bison territory and defended their domain to such an extreme, that "it was death for a strange hunter to intrude." 33 When the United States placed the Delawares in the outlet, the Delawares "could only maintain a footing in their new homes, by incessant fighting." 34 By doing so, they became bitter enemies of the Pawnees, Lakota Sioux, Cheyennes, and Comanches.

Artist George Catlin, who visited and painted portraits of Indian people from the prairies of the mid-west to the Great Plains, noted that the Delawares and other migrant Indians were in a difficult position, for they were scattered and driven westward and "planted . . on the borders of new enemies" where they were forced to "take up their weapons in self-defense, and fight for the ground they have been planted on." 35 He observed that they had "been left on the frontier, surrounded by civilized neighbors-- [and] wilder tribes." 36

30 Major. Clifton Wharton, May 30, 1844 in "The Expedition of Major Clifton Wharton in 1844," Transactions of the Kansas State Historical Society 16 (1923-1925), 284.

31 Weslager, The Delaware Indians, 377.

32 John T. Irving, Indian Sketches Taken During an Expedition to the Pawnee Tribes (Philadelphia: Carey, Lea and Blanchard, 1835), 40.

33 Ibid., 11.

34 Ibid., 10. Also See McCoy, "Survey of Kansas," 304-305.

35 George Catlin, North American Indians, ed., Peter Matthiessen (New York: Penguin Books, 1989), 368.

36 George Catlin, Letters and Notes on the North American Indians, ed. Michael Mooney (New York: Crown Publishers, Inc., 1975), 264. 
Though Catlin pitied these immigrants, he was astonished to discover that small groups of Delawares, or, as he called them, "adventurous myrmidons," visited "remote tribes" as much as 2,000 miles away and "solemnized the articles of everlasting peace with them." 37 This illustrated the ability of the Delawares to adapt to new circumstances when they relocated to the Kansas plains. They became expert bison hunters and dedicated scouts for United States military expeditions. The American author Washington Irving visited a Delaware hunting camp and commented:

The expeditions of the Delawares, whether of war or hunting, are wide and fearless. A small band of them will penetrate far into these dangerous and hostile wilds, and will push their encampments even to the Rocky Mountains. ${ }^{38}$

Delawares also served as scouts and hunters for John Fremont's expeditions to the west as he journeyed to the Rocky Mountains and California in 1842 and 1845. Fremont admired the Delawares for "performing their duties with remarkable courage and fidelity." 39 Delawares were considered by most of the Plains tribes to be "the best warriors amongst the Indians." 40 The American historian, Francis Parkman, visited the Delawares in the 1846 and noted that the "Delaware, once the peaceful allies of William Penn, the tributaries of the Iroquois, are now the most adventurous and dreaded warriors upon the prairie." He added that they were fighting most of the plains tribes and "sending out their little war parties as far as the Rocky Mountains, and into the Mexican territories." Unlike the prosperous Shawnees who "are tolerable farmers," he lamented that the Delawares who were wanderers and warriors "dwindle every year." 41

Delawares collided with the nomadic Cheyennes further to the west. These two Algonquian people symbolized the meeting of east and west among American Indians on the Great Plains. The Cheyennes were a relatively new nation, comprised of many bands that had

37 Catlin, North American Indians, 369.

38 Washington Irving, A Tour on the Prairies (1835; reprint, New York: Time-Life Books Inc., 1980), 120-121.

39 John Fremont in Weslager, The Delaware Indians, 380.

40 Bulletin from the Office of Indian Affairs, Feb. 13, 1837.

41 Francis Parkman, The Oregon Trail (1876; reprint, Garden City, New York: Doubleday \& Company, Inc., 1946), 16-17. 
grouped together in the Black Hills throughout the eighteenth century. The Delawares were the "Grandfathers" of all Algonquians. Cheyennes, however, did not differentiate between the different eastern nations. They called Delawares and Shawnees by the name of Savane (possibly a misinterpretation of the English word Shawnee). Early contact between Cheyennes and Delawares, occurred at Bent's Fort, a trading post located outside of Kansas Territory in southeastern Colorado. The owners of the trading company, Charles and William Bent hired Delawares as teamsters, herders, and hunters. ${ }^{42}$ Eventually the Delawares and Cheyennes became mortal enemies. After several violent confrontations between the two nations, the Cheyennes informed Lieutenant J.W. Abert of Fremont's command that they desired "to bear pacific proposals to the Delawares, who they feared greatly." In August of 1845 the two Indian nations met in a peace council at Bent's Fort. ${ }^{43}$

The Delawares opened the council by passing the pipe to the Cheyenne chiefs. All members sat on buffalo robes and Bill Gurey acted as interpreter for both parties. Sign language became an "important part" of this exchange. "The meeting was conducted throughout with great decorum." 44 Old Bark of the Cheyennes addressed the Delawares:

We have been in great dread less you should make war upon us, and, although our women and children have been suffering for food, were afraid to venture forth, for we are now weak and poor and our ground diminished to a small circle. The whites have been amongst us and destroyed our buffalo, antelope, and deer . . but we are so desirous to keep peaceful that we take no notice of it, for we regard the Delawares and whites as one people. ${ }^{45}$

42 Jean Afton, ed. et al, Cheyenne Dog Soldiers: A Ledgerbook History of Coups and Combat (Niwot: University Press of Colorado and Colorado Historical Society, 1997), 104, 222; David Lavender, Bent's Fort (New York: Garden City: Doubleday \& Company, Inc., 1954); Stan Hoig, The Cheyenne (New York: Chelsea House Publishers, 1989) 32, 36. For more on the formation of the Cheyenne people as a nation see Moore, The Cheyenne Nation.

43 Lt. J.W. Abert, reports on expeditions. Senate document 438, 29th Congress, 4-5. For more on the tensions between Delawares and Cheyennes see the mostly first hand accounts in George Bird Grinnell, The Fighting Cheyennes (1915; reprint, Norman: University of Oklahoma Press, 1956), 76, 91, 94, 122, 128, 162, 278.

44 Abert, reports on expeditions, 5.

45 Ibid., 5. 
The two parties reached a temporary understanding, but intertribal animosity between the two peoples continued and was inevitable as long as Delaware hunters infringed on Cheyenne hunting grounds. It was part of the Delaware nation's difficulties in adjusting to this new region.

The early years of the Delawares in Kansas Territory reflected a nation in transformation. In Kansas Territory they straddled both worlds; that of white civilization as it settled on the prairies and the horse Indian culture of the Great Plains. Their stay in Kansas, as in Missouri, was brief. Demographic pressures regarding the bison herds, made many of the Plains tribes resentful toward immigrant Indians. As early as 1843, the Lakota Sioux boasted that they would "exterminate the tribes south of them--as the Pawnees, Delawares, Shawnees." 46

It was, however, the United States government and not a pan-Indian movement of Plains tribes that eventually removed Delawares and other migrant nations from Kansas. The Manypenny Treaties, which started in 1854 and were concluded in 1866, opened the doors for the building of railroads, towns, settlements, and farms in Kansas. The Delaware Great Council, in what would be one of its last actions, agreed to sell the Delaware reserve to the Leavenworth, Pawnee, and Western Railroad and the Missouri River Railroad Company. Representing the Delaware nation was the head chief John Conner (Turtle), his assistants Sarcoxie (Turtle), and Charles Journeycake (Wolf), and a group of councilors. The Turkey division was not represented in this transaction. 47

The Manypenny Treaty of 1866 allowed for Delawares to remove to Indian Territory (current day northwestern Oklahoma) where the Cherokees gave them tracts of land. ${ }^{48}$ The treaty also stipulated that family heads that "elected to dissolve their tribal relations and to become citizens of the United States" could remain in Kansas and keep eighty acres of reservation land. Those who insisted on keeping their tribal ties were forced to leave their reservations and make the journey to Indian Territory on horseback and in buggies, wagons, and

46 Wedel, Dunbar-Allis Letters, 658.

47 Manypenny Treaty, July 4, 1866, in Indian Affairs: Laws and Treaties, Kappler, ed. 2: 937-942; Weslager, The Delaware Indians, 422.

48 Craig H. Miner and William E. Unrau, The End of Indian Kansas: A Study of Cultural Revolution, 1854-1871 (Lawrence: University Press of Kansas, 1978), 3. 
ox-carts. ${ }^{49}$ The dispersed Delawares, suffered constant loss of land and territorial dislocations at the hands of the United States. Continually pushed westward, in the first half of the nineteenth century, the Delawares reached their final destination in northwestern Oklahoma.

In Indian Territory, the Delawares, in order to live on Cherokee land, gave up their tribal status and became part of the Cherokee nation. They were forced to recognize the Cherokee headmen as their own leaders. All newborn Delaware children were considered to be Cherokee. In 1874, a band of Delawares from the Anadarko Indian Agency merged with and placed themselves under the control of the Caddo tribe. Eventually, the Delaware Great Council lost relevance when both the United States and Cherokee nation failed to acknowledge their principal leaders. Throughout the ensuing years, Delaware leaders, such as James Conner, Black Beaver, Jim Bob, John Secondine, and John Sarcoxie, served their people in the capacity of unofficial chiefs. ${ }^{50}$ In 1894 the Bureau of Indian Affairs, under the Curtis Act, abolished the title of chief among the Delawares. A president presided over the Tribal Business Committee and its body of five prominent men. This became the new governing body among the Delawares, despite their nontribal status. 51

More changes came, which further broke apart the Delaware nation. From 1902 to 1907, Delaware lands in Oklahoma that were purchased from the Cherokees were placed under allotment. Each head of the Delaware household received one hundred and sixty acres, while excess land was sold to white ranchers and settlers. Delawares and Cherokees were continuously embroiled in legal disputes over annuity payments and property rights. In 1979, the Bureau of Indian Affairs once again dealt the Delawares a severe blow when it permanently terminated the tribal status of the Delawares and Shawnees who lived among the Cherokees in eastern

49 Indian Affairs: Laws and Treaties, Kappler, ed., 1: 937; Weslager, Delaware Indian Migration, 226-227; Zornow, Kansas: A History, 94-97. The Eastern Indians were caught between the forces of government and its push to open land to settlers and the railroads attempts to capitalize on land sales in Kansas.

50 Weslager, The Delaware Indians, 422-442, 427-428; Miller, "Delaware," in Hoxie, ed. Encyclopedia of North American Indians, 159.

51 Richard C. Adams, Legends of the Delaware Indians and Picture Writing, ed., Deborah Nichols, (Syracuse: Syracuse University Press, 1997), xxvi-xxvii. Adams (1864-1921) was the tribal historian of the Delawares. 
Oklahoma. After lengthy court battles of twenty years, eastern Oklahoma Delawares, as well as all other Delawares, were given back their tribal status. 52

The Delaware history is an epic of tragic dislocations, migrations, and the search for new thresholds and opportunities. All previous migrations became mechanisms used to attain and hold on to a sense of nation. After 1795, this unity became impossible to hold on to as Delawares were scattered to the four corners of North America. The animal tribes of Turtle, Turkey, and Wolf lost their political significance and were once again relegated to represent only ethnic and clan bonds. In Kansas, United States officials diminished the significance of the individual phratries and referred to them as mere "bands" of the Delaware nation.

Throughout most of the twentieth century, Delawares of Oklahoma remained absorbed into the Cherokee nation. The Delawares, however, remained committed to the concept of nation. The promise of a unified nation is part of their persona, linking together the past with the present and future. As they once removed themselves from the dominance of the Six Nations, Delawares sought autonomy and recognition as a nation. In 1992, Delawares from Oklahoma, Wisconsin and Ontario were brought together to form the Delaware Nation Grand Council of North America--a reinvention and reemergence of the wise men known as the Lupwaaeenoawuk. Currently the United States Bureau of Indian affairs recognizes the Delaware tribe of eastern Oklahoma and the Delaware tribe of western Oklahoma. The Canadian government acknowledges the Delaware tribe of the Thames in Ontario. The Stockbridge-Munsee tribe of Mohican Indians, residing in Wisconsin, acknowledges that they are the "Wolf Sachem" of the Delaware Indian nation. 53 While Delaware groups remain geographically dispersed, a sense of a common history and culture unifies the Delawares into an awareness of themselves as being components of a prestigious and influential Indian nation.

52 Lee Sultzman, website for the Delaware Tribe of Oklahoma, 26-27. Available from lenape@cowboy.net, INTERNET; Weslager, The Delaware Indians, 440-456.

53 Bureau of Indian Affairs website on federally recognized tribes. Available from http://www.doi.gov; INTERNET; The Stockbridge Munsee Tribe of Mohican Indians website. Available from homepage/mohican; INTERNET. 


\section{Appendix 1: An Ethno-Political Definition of the Delaware Indians}

A key point of contention in the study of Delaware Indian history is the confusion and historical debate on what ethnic and political groups comprised the Delaware peoples. Much of the misunderstanding has been rooted on false information or careless observations and assertions.

The Lenape "original people," "common people," or "original folk" were comprised primarily of three distinct groups of Indians from the Algonquian (Algonkian) linguistic family. They consisted of the proto-Lenapes, which included the northern Unamis ("People down the river"), the southern Unamis (also referred to Unalachtigos, "People who live near the ocean"), and the Munsees or Minisinks ("People of the stony country"). The Unami-speakers lived close by one another on both banks of the Delaware River. The Munsee-speakers lived to the north, in the lower Hudson River Valley and at the forks of the Delaware River. ${ }^{1}$ According to Paul A. W. Wallace, the Unami and Munsee boundaries "were nebulous." 2 These linguistic groups would also be strongly identified with their respective extended clans or animal phratries. They included the Turtle (Poko unko) and Turkey (Pele) tribes, who were Unami-speakers, and the Wolf tribe, who were Munsees. ${ }^{3}$ In 1600, there was an estimated population of 8,000 Unami and Munsee Indians. ${ }^{4}$

1 William A. Hunter, "Sub Divisions of the Delawares," 28; Goddard, "Delaware" in Trigger ed., Handbook of North American Indians, 215; Weslager, The Delaware Indians, 31-32, 43-47; Hitakonanu'laxk, Grandfathers Speak, 6. See the correspondence of Nora Thompson Dean, a renowned Unami linguist, regarding the phrase "common folk" in Herbert C. Kraft, "The Northern Lenape in Prehistoric and Early Colonial Times," in Kraft, ed., The Lenape Indians, 1.

2 Paul A. W. Wallace, Indians in Pennsylvania, second edition, revised by William A. Hunter (Harrisburg: Commonwealth of Pennsylvania Historical and Museum Commission, 1993), 52.

3 The Moravian missionaries, David Zeisberger and John Heckewelder adhered to a Unami $=$ Turtle, Unalachtigo $=$ Turkey, and Munsee $=$ Wolf equation, with regards to the ethnopolitical structure of the Delawares. This terminology has been debated for generations among scholars. See Zeisberger in Schwarze and Hulbert, eds., "Zeisberger's History," 27, 92; Heckewelder, An Account of the Indian Nations, 51-52.

4 Swanton, ed., Indian Tribes of North America, 54-55. These numbers dwindled to 3,000 during the eighteenth century and during the Census of 1910, the Delawares were estimated at a population of 985 . 
The English eventually classified these people collectively as "Delaware" Indians--a geographic, rather than ethno-political designation. ${ }^{5}$ Originally, the Lenape Indians resented the term. To appease their discontent, the English reminded them that Virginia governor Thomas West was " a great white chief." Ironically, West never met the native peoples who lived along the "de la Warr Bay" and would be named as such in his honor. ${ }^{6}$

Throughout the mid to late eighteenth century, the Moravian missionaries, David Zeisberger and John Heckewelder knew the Delawares on an intimate basis and were privy to the social and political composition of the Delaware tribes. Both maintain that the Delaware nation was ordered along totemic lines. They contend that the Turtle, Turkey, and Wolf tribes or phratries were hierarchically ranked and comprised the Delaware nation. Unami or Packoango was the Turtle tribe ("unfeathered animal"), Unalachtigo or Blem ("scratching fowl") the Turkey group, and Munsee or Ptucksit, ("round paws"), the Wolf tribe. Countless scholars, at times, out of convenience, acknowledge this "tripartite geographical division" of Turkey, Wolf, and Turtle tribes. $^{7}$

Others have been deceitful in the application of Zeisberger's and Heckewelder's research. The Wallam Olum, a pictographic chronicle of symbols drawn on sticks, is purported to be the tribal history as recorded by the Lenape Indian people. Also referred to as the Red Record, this epic saga tells of a time during the early 1600s when the Lenape population and territory expanded. To accommodate this growth and to remain a cohesive nation, the sachem and the council of these people decided to restructure the tribe by dividing the Lenape into three divisions. The dividing line of the three groups became the "upstream, midstream, and downstream regions of the Delaware River." 8 The record states that to remain strong, the Lenape formed three tribes which would constitute their nation, "Three were desired, so three

5 Heckewelder, An Account of the Indian Nations, 26; Weslager, The Delaware Indians, 31-32; Wallace, Teedyuscung, 6-7.

6 Heckewelder, An Account of the Indian Nations, 26.

7 Zeisberger in Schwarze and Hulbert, eds., "Zeisberger's History," 92; Heckewelder, An Account of the Indian Nations, 50-51, 110, 246; Wallace, Teedyuscung, 6-12.

8 David McCutchen, trans., The Red Record, The Wallam Olum: The Oldest Native North American History (Garden City Park, New York: Avery Publishing Group Inc., 1993), 137; Brinton, Lenape and Their Legends, 214. 
were to be: Unamini, Minsimini, Chikimini.” They became known as the Unamis, Munsees, and Unalachtigos. ${ }^{9}$

The Red Record was the supposed written history of the Delaware people from their existence in Siberia to the 1600s. The entries are fragmented in its explanation of Delaware history from 1620-1820. This record was recorded by making pictographic drawings on sticks. I say purported for Constantine Rafinesque translated this cryptic record from 1826-1833. This scholar obtained these sticks from a medical doctor who, in turn, had received them earlier from an elderly Delaware record keeper who gave the sticks to the doctor as payment for medical treatment. Though Rafinesque was a professor of botany and natural history, and modern languages at Transylvania University in Kentucky, the Red Score in most cases, should be approached as Rafinesque's literary embellishment, a fantasy, and a corruption of Delaware oral history and the writings of Zeisberger and Heckewelder, rather than historical fact. ${ }^{10}$

This epic tale of tribal migration and reorganization was mythical in origin and not grounded on historical evidence. It remains another piece of literature that contributes to the confusion on what groups of people comprised the Delaware Indians. There are, however, certainties. Many historians agree with the historical record and the assertion that the Delaware tribes during most of the seventeenth century were "dispersed in numerous autonomous villages and communities throughout the Delaware River drainage system" (eastern Pennsylvania and New Jersey). ${ }^{11}$ These tribes were culturally and linguistically different at the time of first contact with Europeans during the seventeenth century. ${ }^{12}$

An intense debate has raged among historians, ethnologists, and anthropologists regarding the social and political organization of these Delaware tribes. Past and current scholars have locked horns on the issue of what ethnic-political-geographic groups comprised the people known collectively as Delawares.

9 Ibid., 136.

10 For a total (and scholarly) dismantling of the Wallum Olum see David M. Ostreicher, "Unmasking the Walum Olum: A 19th Century Hoax." Bulletin of the Archaeological Society of New Jersey 49 (1994): 1-44.

11 C.A. Weslager, "More About the Unalachtigo," Pennsylvania Archaeologist 44 (Sept. 1975): 41.

12 Sugrue, "The Peopling and Depeopling of Early Pennsylvania," 30. 
The crux of the argument revolved around the three main tribes of Delawares and their significance to one another and whether the three tribes functioned as a distinct political group or, as other scholars have questioned, whether three existed at all. C. A. Weslager, the Rutgers scholar and specialist on Delaware Indian history, writes that the Munsee, southern Unami, northern Unami (known as Unalimi), and Unalachtigo tribes designated geographic regions and were not indicative of distinct political groups. The Delaware tribes in their eastern homeland did not have a functioning political cohesion as a nation. ${ }^{13}$

The esteemed anthro-historian Anthony F. C. Wallace opposes the use of the three tribes to explain the components of the Delaware nation. He considers this an "erroneous ascription of political and territorial values to the sib system" of clans. ${ }^{14}$ Wallace notes that Heckewelder and other Moravian missionaries observed three clans among the Delawares and made the haphazard assumption that these clans were of a specific "geographical division to correspond to their social organization."15 Most importantly, he offers a rather strong definition of Delaware social units from 1600-1763. Wallace considers Delaware society to be based on units of a maternal lineage, each with defined hunting and fishing boundaries. Observers, such as Heckewelder, witnessed several units locked together in group pursuit of sustenance, each comprised of "at least" the three clans. Communities of Delawares also made "temporary alliances" among themselves in times of war. This was a common occurrence among the Delawares at that time. ${ }^{16}$ Thus Moravian missionaries concluded that Delawares, as a whole, were divided into three specific groupings, when in reality the clans were interacting with one another.

Lewis Henry Morgan, the early American ethnologist, did extensive fieldwork with the Delawares in Kansas Territory during the 1850s. Morgan's chief informants, Charles Journeycake, a Turtle chief, and his wife, told Morgan that within the three animal groups there were twelve subdivisions. For a great period of time, Delawares married within their animal phratry, but could not marry within their individual clan or sub division. Eventually this changed

13 Weslager, The Delaware Indians, 43-47.

14 Wallace, Teedyuscung, 6-12.

15 Wallace, "Woman, Land, and Society," 15.

16 Ibid., 20. 
and, people married outside of their animal tribe. Residency was always determined along the female line. ${ }^{17}$

Pennsylvania historian William Hunter offers the most tangible explanation regarding the identification of the Delaware Indians. Hunter contends that there was a major difference between Delaware tribe (groups who were ethnically linked) and Delaware nation (those who were politically connected). Hunter concludes that the Munsees were not ethnic Delawares but were politically linked. Many of the Moravian Christian Munsees attached themselves to the Delawares who moved west of the Allegheny Mountains. At a later time, Munsees from the upper Allegheny region followed their Christian Delaware brethren further west. These Munsees eventually became a component of the political nation. By 1791, the remaining Munsees moved north into Seneca country and were subsumed into the Seneca nation. ${ }^{18}$

The name Delaware has been used as a generic term and a term of convenience in reference to the Lenape proper, northern and southern Unami speakers, and includes, and at various times excludes, the Munsee group. The identification of the Delawares has transcended, either through correct interpretation or erroneous observation, from a linguistical-geographical designation into a political definition by the 1750 s. The term Unalachtigo has been extremely problematic to rely upon through historical documentation. For the most part, the term can be found in Moravian mission records and was mentioned by Delawares such as Teedyuscung and Moses Tatamy. The late nineteenth century ethnologist Daniel Brinton asserts that the Unalachtigos might have been remnants of the Nanticokes who were known as Unechtigo mingled with groups of Delawares and Mahicans on the Upper Susquehanna and later the Ohio country. ${ }^{19}$ Other scholars, such as Hunter, Weslager, and anthropologist, Jay Miller further their views on the Delawares called the Unalachtigos. Hunter concludes that the term Unalachtigo was in use from 1769 to 1785 to designate certain New Jersey Lenapes who migrated to eastern Ohio. ${ }^{20}$ Weslager writes that because of its close semblance to the Unami dialect, the term Unalachtigo was temporary, “destined for obsolescence" and had different renditions such as Wunalachtikok, Wunalachtko,

17 Lewis Henry Morgan, The Indian Journals: 1859-1862, edited by Leslie A. White, (1859; reprint, New York: Dover Publications Inc., 1993), 57-59.

18 Hunter, "Sub Divisions of the Delawares," 31, 35.

19 Brinton, Lenape and Their Legends, 88.

20 William A. Hunter, "A Note on the Unalachtigo," in Kraft, ed., A Delaware Indian Symposium, 150-151. Also see Hunter, "Sub Divisions of the Delawares," 20-40. 
and Wunalachtico. ${ }^{21}$ Miller, a scholar of Lenape heritage, criticizes historians who are "shackled to the written word" and argues that Unalachtigo was a "descriptive term" to identify the Winetkoks, which he believes is the correct title for the third tribe of Delawares. ${ }^{22}$ While there has only been scant reference to the Unalachtigo in historical documentation, the term is ingrained in many modern-day definitions of the Delaware nation.

There is also a debate regarding the zoological classification of the phratries of Turkey, Turtle, and Wolf as specific divisions as forwarded by Heckewelder and Zeisberger, though also supported in part by current scholars such as Ives Goddard and Melburn D. Thurman. Goddard acknowledges these three animal divisions, but rejects the classification of Heckewelder and his equation of Unami=Turtle, Munsee=Wolf, and Unalachtigo=Turkey. ${ }^{23}$ Through his analysis of the Delaware language, Goddard maintains that the three animal tribes constituted the Delaware ethnic nation, not to necessarily imply a political nation. According to Goddard, the Delawares as an ethnic-political entity were structured around two distinct dialects, Unami and Munsee. ${ }^{24}$ Thurman, in his ethnohistorical study of Delaware social structure, supports much of the Moravian findings. He particularly adheres to the Munsee $=$ Wolf equation of Heckewelder. ${ }^{25}$ In response to Wallace's contentions that the Unalachtigo never existed because there was no record of current-day Unalachtigos in Oklahoma or Canada, Thurman concludes, "one cannot demonstrate the non-existence of a social group in the past by showing that no members of that group presently survive."26

Raymond Whritenour, the editor of A Delaware-English Lexicon is not as quick to dispel the Heckewelder equation. Though Whritenour humbly refers to himself as "an armchair enthusiast," he rather eloquently argues on behalf of Heckewelder's defense. Whritenour insists that Heckewelder did not create this classification, but merely passed on the information of an "aged Lenape informant" in the 1760s. ${ }^{27}$ Whritenour demonstrates that each Delaware phratry had a series of clans within. The Wolf phratry contained a Wolf clan and a Crow clan and within

21 Weslager, "More About the Unalachtigo," 42; Weslager, The Delaware Indians, 45.

22 Jay Miller, "The Unalachtigo?," Pennsylvania Archaeologist 44 (Dec. 1974): 7-8.

23 Heckewelder, An Account of the Indian Nations, 50-51, 110, 246.

24 Goddard, "Delaware," 213, 221.

25 Thurman, "Delaware Indians in Ethnohistory," 106-116.

26 Ibid., 89.

27 Raymond Whritenour in correspondence with James Rementer, November 17, 1996, 2. 
the Turkey division there was a Big Turtle and Little Turtle clan. These groups functioned in a "totemic system" in which "competitive clans would have to have lived in close proximity to each other--further strengthening the idea that their combined identity (the phratry) designated a collection of geographically contiguous bands." 28 Most importantly, he conveys a very convincing and plausible argument regarding the Wolf division as being the Munsees. Whritenour uses the formation of the Big House Ceremony (a national religious ceremony of the Delawares) to prove his point. Each Delaware phratry took specific seats in the longhouse, which contained the Big House Ceremony (Gamwing or Nkamwin). The Turkey men and women were seated along the southeast wall of the longhouse and the Turtle men and women to the southwest. The Wolf men and women lined the north wall of the ceremonial longhouse. Thus according to Whritenour, the seating arrangement suggests a "microcosmic picture of the Lenapes' ancestral homeland." Munsee groups lived north (Lower Hudson and Upper Delaware rivers) of the Unami-speakers. ${ }^{29}$ Whritenour's analysis certainly supports the Heckewelder equation regarding Delaware divisions and the often-disputed tri-partite classification.

Weslager, ever the skeptic, concludes that by using the terminology of a three-division Delaware nation pertaining to 1769 , "does not necessarily mean that there was an eternal 3-fold division of the Delaware" which pre-dated western migration. ${ }^{30}$ While he makes a salient point, Weslager fails to take a position. Delawares who migrated west throughout the eighteenth century were in a state of crisis. They possibly increased social and political organization to meet those challenges in their new homeland of the Ohio country. This is most evident in the observations of Colonel Henry Bouquet, the Swiss-born British officer. In his papers, Bouquet acknowledges the importance of the three animal divisions as vital components of the collective Delaware nation. He treated each tribe as a sovereign entity when he sought the release of English captives by the Ohio tribes in November 1764. Bouquet makes ample references to the Turtle,

28 Ibid., 5.

${ }^{29}$ Ibid., 5. For more details on the mechanics and significance of the Big House Ceremony see Robert S. Grumet, ed., Voices from the Delaware Big House Ceremony: In Native Text Dictated by Witapanoxwe (Norman: University of Oklahoma Press, 2001; Frank Speck, A Study of the Delaware Indian Big House Ceremony (Harrisburg: Pennsylvania Historical and Museum Commission, 1931). For drawings and diagrams of the outside and inside of the traditional ceremonial longhouse see Grumet, ed., Voices from the Big House Ceremony; Weslager, The Delaware Indians, 13, 18, 70.

30 Weslager, "More About the Unalachtigo," 41. 
Turkey, and "Wolfe" phratries of Delaware Indians as he negotiated separately with the principal leaders of these tribes. ${ }^{31}$

The Papers of Henry Bouquet serves as an invaluable tool in removing the confusion. In my research, while I have seen many separate references to the Turtle and Turkey tribes as autonomous entities, the Wolf tribe is seldom mentioned at the same time as the Munsees. In many treaty talks, such as the Bouquet talks in 1764, the Wolf or Munsee tribe is dealt with separately from the Unami-speaking Turtle and Turkey Delawares. At other councils with the Delawares when acknowledging the three animal tribes, the Munsees are not mentioned. Also the two principal Delaware leaders during the Seven Years' War and American Revolution, Custaloga and Captain Pipe are referred to at various times as Munsees and at other times as chiefs of the Wolf tribe, to verify that the Wolf tribe and Munsees were the same. Throughout this dissertation, I have presented further evidence. I believe the Turtle and Turkey tribes (northern and southern Unami speakers) were the proto-Lenape and the Wolf tribe was the Munsees. Together these ethnic-linguistic-political groups made up the Delaware Indian nation during the eighteenth century.

${ }^{31}$ Stevens and Kent, eds., The Papers of Henry Bouquet. 


\section{Appendix 2: A Historiography of the Delawares as "Women"}

With this supposed tributary status of the Delawares as members of the Covenant Chain of Friendship, came the confusing and misinterpreted metaphor of "woman." David Zeisberger and John Heckewelder rely steadfastly on their Delaware sources. They believe that the Delaware designation as "women" was predicated on their strength and reputation as the foremost prominent of all Algonquian warriors and diplomats. ${ }^{1}$ As the women in the Covenant Chain, the Delawares were "entrusted with the charge of the great belt of peace and the chain of friendship." They were responsible with preserving and bearing the chain of peace on their shoulders, "at its middle," while the other Indian nations and the English held up the ends. ${ }^{2}$

Since the days of Zeisberger and Heckewelder, scholars have been engaged in intense debates and discussions regarding how perceptions shaped the application of the term between the Iroquois Confederation and the Delawares. They have also attempted to explain or rationalize how the metaphor of "woman" regressed into a term of weakness and subservience.

The assumption that the Delawares were a conquered people came largely as a result of Francis Parkman's inexhaustible study of the seventeenth-century North American frontier. During the 1870s and 1880s, Parkman, Americas preeminent historian, spent an academic career branding the Iroquois Six Nations as merciless predators whose warriors raided, burned, and leveled everything in their path. Parkman, swayed by Jesuit sources and gifted with a nineteenthcentury sense of literary flair, emphasizes and embellishes Iroquois ruthlessness. He portrays the Iroquois tribal environment and its rituals, similar to that of a medieval horror chamber; a Hieronymous Bosch painting come to life, complete with boiling cauldrons filled with amputated limbs, blood-drenched scalps, and human remains being devoured by remorseless cannibals. Parkman sees the Iroquois as a people who were addicted to conquest and who used conflict as a device to vent out intense emotions of animal rage. He helps to produce a legend that all surrounding Indian tribes trembled at the mention of these "tyrants of all the intervening

1 Zeisberger in Schwarze and Hulbert, eds., "Zeisberger's History," 34-35; Heckewelder, An Account of the Indian Nations, 58.

${ }^{2}$ Zeisberger in Schwarze and Hulbert, eds., "Zeisberger's History," 35. 
wilderness." 3 Parkman and other observers of the Iroquois, such as Lewis Henry Morgan, use their imaginations to transform the Iroquois into a political and military juggernaut, which gained more power with each military victory over enemy tribes, with the Delawares as one of their victims. ${ }^{4}$

Francis Jennings, in The Ambiguous Iroquois Empire, is very willing to down play any notion that the Delawares were conquered women. He adamantly assaults any notions of Iroquois supremacy as a colonial empire. Jennings dismantles the myth of this empire by illustrating how the Iroquois imperial reputation was built around a series of concoctions, distortions, and convolutions ${ }^{5}$--all by-products of English invention and perpetuated in the future by scholars such as Parkman and Morgan. As Jennings illustrates, the historical reality refuted the imperial status of the Iroquois.

According to Jennings, the Five Nations aligned themselves with Edmund Andros and the New York colony in 1677 and served to replace the Chesapeake colonists and Susquehannock Indians who had declined in influence and power in the Susquehanna and Delaware valleys. ${ }^{6}$ Jennings demonstrates how the Iroquois had little to do with the Susquehannock Indian defeat and dismantling. Jennings believed that the Iroquois merely stepped into a power vacuum created after the frontier violence of 1675 and 1676. In 1663, Iroquois war parties (mostly Senecas) suffered continuous defeats at the hands of the Susquehannocks. At the same time, Maryland officials fired an ultimatum that the Susquehannocks move farther south--which in essence let the flood gates open as Marylanders and Virginians overwhelmed and slaughtered these Indians. The Iroquois then reentered the Susquehanna Valley to claim victory. ${ }^{7}$ Their empire was strengthened by default and not necessarily through political and military skill.

Using this instance as the model for further Iroquois and English contrivances regarding empire building, Jennings also attempts to demonstrate how the Iroquois had not conquered the Delawares. The distortion of an Iroquois-dominated Delaware nation became a reality when the

${ }^{3}$ Francis Parkman, France and England in North America, 2 vols. (1885; reprint, New York: The Library of America, 1983), 1: 710.

4 Also see Lewis Henry Morgan, League of the Ho-de-no-sau-nee, Iroquois (1851; reprint, New York: Corinth Books, 1962).

5 Jennings, Ambiguous Iroquois Empire, 22-23.

6 Ibid., 292-293.

7 Ibid., 128-129. 
Iroquois orator, Canasatego, building his own political reputation, berated the Delaware leaders at the council in Pennsylvania in $1742 .^{8}$

Jennings comes to the defense of Zeisberger and Heckewelder by pointing out that in the "Indian sense," the status of woman was honorable--the intended designation of tributary was fluid. Metaphorically the Delawares were women to the Iroquois men (a relationship based on prestige and honor), but Delawares were also called "nephews, cousins, and grandfathers." Grandfather was the Iroquois acknowledgement of the Delawares as the foremost ancient of all Algonquian people. ${ }^{9}$ In general, the tributaries of the Iroquois were both allies and subordinates. They were locked into a reciprocal relationship of "responsibilities as well as privileges" within the Confederation. ${ }^{10}$ Regarding the Confederation and domination of its tributaries, Jennings reminds us that "no multitudes groaned underneath the hobnailed moccasin" of the Iroquois. ${ }^{11}$

The anthropologist Frank Speck has aptly sifted through the confusing meanings of the woman metaphor, by analyzing kinship relations. According to Speck, a distinct characteristic of Eastern Woodland tribes was the "tendency to give each other ratings of relationships according to a kind of sanguinity that one would find in the extended branches of a large family." 12 Speck asserts that the Iroquois eventually came to believe that they had the right to place the Delawares in a position of social and political subservience. Delaware status had changed from that of the respected and revered "Grandfather" to that of "women" signifying female captives who were taken in war. The Delawares, as women, were forbidden to go to war or act as diplomats in treaty talks. "Their entire political organization," through this gender designation, was "deprived of masculine prerogatives" such as war making and diplomacy. ${ }^{13}$

${ }^{8}$ Ibid., 22-24. Pennsylvania Secretary James Logan also believed this fallacy. In 1712, he conferred with a Delaware delegation on its way to Iroquoia with wampum presents. Not understanding Indian diplomatic protocol, Logan assumed that the exchange of wampum meant that the Delawares were paying tribute to the Iroquois. The Delawares in fact were political equals and the exchange of wampum was customary etiquette among Indian nations.

9 Ibid., 160-161. Also see Wallace, Weiser, 271, 450.

10 Jennings, Ambiguous Iroquois Empire, 8.

11 Ibid., 94. Jennings notes that there was no evidence of a battle or war in which the Iroquois conquered the Delawares. See Francis Jennings, "Pennsylvania Indians and the Iroquois," in Richter and Merrell, eds., Beyond the Covenant Chain, 79-80.

12 Speck, "The Delaware Indians as Women," 379.

13 Ibid., 377. 
Jay Miller maintains that despite this emasculation, it was by Delaware consent. In the late 1670s, the Lenape bands had bore the "brunt of contact" with Europeans and desired to "minimize intercourse" in the future. Thus the status of women became preferable to Delawares who favored a neutral position in the escalating conflict became Europeans and Indian nations. The designation of warriors and diplomats appealed to the more-isolated Iroquois. Miller writes: "Iroquois vanity, if not superiority, would have espoused the status of men." 14

Jane T. Merritt, who has studied language and metaphor on the Pennsylvania frontier, cautions the reader to know that in the Iroquois construct the word woman, as it corresponded to the Delawares, meant a "restricted public role." While Iroquois women had a degree of "economic autonomy" within domestic spheres (they owned the longhouse and controlled the resources of agriculture) and could attend treaty talks, they had "limited power to speak in political forums." 15 In its application to the Delawares, the Iroquois used the term "woman" as a diplomatic tool of restraint. The Iroquois eventually altered the perception to fit the European concept of female in which women had no legal right to land. The Iroquois corrupted the metaphor as a way to “delineate Delawares' subordinate position in terms that Euramericans would clearly understand." 16 Regarding the public role limitations placed upon the Delawares by the Iroquois, Anthony F. C. Wallace concludes that the Delawares, despite the lack of male prerogative regarding war making, could overcome the restrictions and go to war if they secured sanction from the Iroquois council fire at Onondaga. ${ }^{17}$

A clique of current-day scholars, driven by political correctness, romanticization, and radical feminism, disagree and have elevated Iroquois women to a prominence that has probably transcended historical reality. By doing so, they also unintentionally change the status of Delawares in their relationship with the Iroquois. They maintain that any corruption of the term to signify weakness was conjured by chauvinistic Euramericans and not Indians.

14 Jay Miller, “The Delaware as Women: A Symbolic Solution,” American Ethnologist 1 (August 1974): 511.

15 Jane T. Merritt, "Language and Power on the Pennsylvania Frontier," in Cayton and Teute eds., Contact Points, 79.

${ }^{16}$ Ibid., 79. For more on gender, language, and the meaning of words among the Delawares see Gunlog Fur, "'Some Women Are Wiser than Some Men': Gender and Native American History," in Nancy Shoemaker, ed., Theorizing the Past in Native American Studies (New York: Routledge, 2002). 75-103. 
In her critically acclaimed literary work Sacred Hoop: Recovering the Feminine in American Indian Traditions, the native writer Paula Gunn Allen, like many revisionists, contends that Iroquois polity was structured solely on matriarchal prerogative and power. Allen writes that the Iroquois, under the old laws before white contact, were a "mother-centered, mother-right people whose political organization was based on the central authority of the Matrons, the Mothers of the Longhouses," also known as clan mothers. She acknowledges the "Red Roots of White Feminism" when she crafts a "gynocratic" nexus between Deganawidah, the prophet who gave the Iroquois the Great Law, and Susan B. Anthony, the leader of the early American suffragette movements. ${ }^{18}$

Other writers, such as Barbara Mann, follow suit. Mann is particularly leery of and hypersensitive to traditional western scholars who approach Indian history and culture in a "linear mode," where "information is packaged and stacked in neat categories." She believes that a true understanding of Indian history should be extracted through a "Native framework"--through a trusting reliance on native oral traditions, where data "scatters naturally, however it happens to fall." ${ }^{19}$ Mann is quite adamant in her beliefs regarding the power of women in Indian societies, both past and present. Without historical documentation, she maintains that it was the Iroquois Clan Mothers who ordered Captain Pipe to remove the Christian Delawares from the Muskingum to the Upper Sandusky region in $1782 .{ }^{20}$ Mann concludes that the "Euro-Forming" of Indian studies has reduced the role of women and the symbolic meaning of the term and how it was applied to the tributary nations, such as the Delawares.

Joy Bilharz in her study of Seneca women, stresses that Iroquois society embraced "complimentary gender roles" in accordance with a horticultural society in which males were

${ }^{17}$ Wallace, "Woman, Land, and Society," 25.

18 See Paula Gunn Allen, The Sacred Hoop: Recovering the Feminine in American Indian Traditions (Boston: Beacon Press, 1986), 33, 213.

${ }^{19}$ Barbara A. Mann, "Epilogue: Euro-Forming the Data," in Bruce E. Johansen, ed., Debating Democracy: Native American Legacy of Freedom (Santa Fe, New Mexico: Clear Light Publishers, 1998), 185-186.

${ }^{20}$ Mann, "'I Hope You Will Not Destroy," in Mann, ed., Native American Speakers, 148-149. She bases this assertion on her belief that the Delawares during the American Revolution were still subservient to the Six Nations. Throughout her essay, she continually refers to the "League" and its powerful influence upon the "Lenape." In her views, at the apex of this power were the Clan Mothers. 
frequently hunting or on the war trail. Iroquois women took greater control of the village in the absence of the men. Regarding Iroquois women and power, Bilharz cautions that "while women were instrumental in naming Confederacy chiefs, it is important to note that this prerogative of women in certain clans cannot be extrapolated to infer political power for all women" in Iroquois society. $^{21}$ The point here is that the Iroquois and many other Indian societies embraced a philosophy of equilibrium and cooperation between men and women. Each gender had role expectations and responsibilities relative to the welfare of the collective whole.

This belief that women were at the center of the Indian universe is an image that anthropologists Daniel Maltz and Joallyn Archambault, the latter of whom is a Standing Rock Lakota Sioux, refer to as "Utopian Fantasies." In this academic distortion, American Indians and their cultures are romanticized to unrealistic and unattainable standards. Maltz and Archambault point to writers such as Paula Gunn Allen as proliferating the historical distortions of the power of Iroquois women in the colonial world. ${ }^{22}$ Such a misinterpretation of the Iroquois as the ultimate feminist society is a romantic stereotype--a return to the days of Jean-Jacques Rosseau and his "cult of the Noble Savage." This view is also as extremist as confirming the early European stereotype that all Indian women were beasts of burden. These utopian feminist fantasies do not reflect the true historical relationship between the Six Nations and their Delaware tributary. To reiterate, in its ideal form the Iroquois and Delawares had a relationship of obligations, responsibilities, and cooperation toward one another. Historical forces destroyed the ideal.

21 Joy Bilharz, "First Among Equals?: The Changing Status of Seneca Women," in Laura F. Klein and Lillian A. Ackerman, eds., Women and Power in Native North America (Norman: University of Oklahoma Press, 1995), 107. This cooperation between the genders extends to the oral traditions of the Iroquois Confederacy. In Iroquois cosmology, Sky Woman was the first human to land on the Earth. She was considered to be Mother of the Earth. Equally important to the history of the Iroquois, the Great League of Peace (the Five Nations Confederation) was founded by the prophet Deganawidah and his disciple Hiawatha. Thus the beginning of the Earth has a feminine origin, while the political genesis of the Iroquois League has a masculine influence. For superb works on the foundation, function, and structure of the Iroquois Confederation see Donald A. Grinde, Jr., The Iroquois and the Founding of the American Nation (San Francisco: The Indian Historian Press, Inc., 1977); Fenton, Great Law and Longhouse.

22 Daniel Maltz and Joallyn Archambault, "Gender and Power in Native North America," in Klein and Ackerman, eds., Women and Power in Native North America, 243. 
These relationships were also not set in stone. Indian symbolic relationships were fluid and ever changing. Delawares themselves decided when and where they would adhere to or reject their status as women. In October of 1755, the Delawares declared war against Pennsylvania and asserted that they were no longer tributaries of the Six Nations. Months later, to avoid the wrath of Sir William Johnson and the British, the Delawares "wrapped themselves in their identity as women to exonerate themselves." Two years later in the spring of 1757, Delawares and Shawnees shed their petticoats and threatened an Iroquois delegation that they would retaliate and make women of them. Jane Merritt concludes that the Delawares as well as the Six Nations manipulated the flexible term of women "for their own ends." ${ }^{23}$ Merritt has also demonstrated that the term had a dual meaning in Indian society. On one hand it could be used to denote the respected role as a peacemaker, while the term woman could also be hurled in contempt to shame males or tribes who lacked military prowess. ${ }^{24}$

By wearing the diplomatic symbol of a petticoat, the Delawares became fully Europeanized to signify the weakness of a woman, rather than the peace-making ability once attributed to them. By the mid 1700s the Iroquois, using Anglo rationalization and to bolster their waning status in the eyes of the British, started to believe their own press. Regarding the metaphor, it continued to lose its original expression of respect and alliance and through gradual and continuous misinterpretation and political manipulation, it became a title of derision. This corrupted metaphor placed a humiliation upon the Delawares and forced them westward into new regions. With this migration, the Delawares removed the burden of subservience, placed upon them by an intrusive Six Nations of Iroquois.

${ }^{23}$ Merritt, "Language and Power on the Pennsylvania Frontier," in Cayton and Teute, eds., Contact Points, 80 .

${ }^{24}$ Ibid., 78. 


\section{BIBLIOGRAPHY}

\section{Primary Works}

Abert, Lt. J.W. Reports on Expeditions. Senate document 438, 29th Congress.

Afton, Jean., et al., eds. Cheyenne Dog Soldiers: A Ledgerbook History of Coups and Combat. Niwot: University Press of Colorado and Colorado Historical Society, 1997.

Alden, Timothy, ed. "An Account of the Captivity of Hugh Gibson among the Delaware Indians of the Big Beaver and Muskingum from the Latter Part of July 1756 to the Beginning of April, 1759." Collections of the Massachusetts Historical Society. 6 (1837): 140-153.

American State Papers, 1832-1861: Indian Affairs. Washington, D. C.: United States Government Printing Office, 1904.

"An Historical Account of the Expedition Under the Command of Henry Bouquet, Esq., Against the Ohio Indians in the Year 1764.” Author Anonymous. Dublin: John Milliken, 1769.

Bierhorst, John. Mythology of the Lenape: Guide and Texts. Tucson: University of Arizona Press, 1995.

Bliss, Eugene F., ed. Diary of David Zeisberger: A Moravian Missionary Among the Indians of Ohio. 2 vols. Cincinnati: Robert Clark \& Co., 1885.

Booth, Russell, ed. The Tuscarawas Valley in Indian Days, 1750-1797. Cambridge, Ohio: Gomber House Press, 1994.

Boyd Julian P. and Carl Van Doren, eds. Indian Treaties Printed by Benjamin Franklin, 17361762. Philadelphia: Historical Society of Pennsylvania, 1938.

Bradley, Daniel. Journal of Captain Daniel Bradley: An Epic of the Ohio Frontier. Greenville, Ohio: Frank H. Jobes and Son, 1935.

Browne, William Hand, ed. Archives of Maryland: Proceedings of the Council of Maryland, 1693-1697. 69 vols. Baltimore: Maryland Historical Society, 1887-1903.

Bulletin from the Office of Indian Affairs, Feb. 13, 1837.

Calloway, Colin G., ed. Revolution and Confederation, vol. 18 of Early American Indian Documents: Treaties and Laws, 1607-1789. Alden T. Vaughan, gen. ed. Bethesda, Maryland: University Publications of America, 1994.

. The World Turned Upside Down: Indian Voices From Early America. New York: Bedford Books of St. Martin's Press, 1994. 
Catlin, George. Letters and Notes on the North American Indians. Michael Mooney, ed. New York: Crown Publishers, Inc., 1975.

. North American Indians, Peter Matthiessen, ed. New York: Penguin Books, 1989.

"chiefs of the Delaware Indians at Allegaeening." Philadelphia: Historical Society of Pennsylvania. Miscellaneous Collection, Indians 1732. box 11c.

“Correspondence of Conrad Weiser.” Mss. Philadelphia: Historical Society of Pennsylvania.

Cresswell, Nicholas. The Journal of Nicholas Cresswell, 1774-1777. New York: The Dial Press, 1924.

“Croghan's Report, 1765.” In Clarence Walworth Alvord and Clarence Edwin, eds. Collections of the Illinois State Historical Library. vol. 11. The New Regime, 1765-1767. Springfield: Illinois State Historical Library, 1916.

"Croghan's Transactions with the Indians Previous to Hostilities on the Ohio." In Reuben G. Thwaites, ed. Early Western Travels, 1748-1846. 32 vols. Cleveland: Arthur H. Clark, 1904-1907.

Cruikshank, General E. A., ed. The Correspondence of Lieut. Governor John Graves Simcoe, With Allied Documents Relating to His Administration of the Government of Upper Canada. 5 vols. Toronto: Ontario Historical Society, 1923.

Darlington, Mary, ed. Fort Pitt and Letters From the Frontier. 1892. Reprinted. New York: Arno Press, Inc., 1971.

Early Western Journals, 1748-1765 by Conrad Weiser, 1748; George Croghan, 1750-1765: Post, 1758; and Thomas Morris, 1764. ed. Reuben Gold Thwaites. Separate publication from Early Western Travels, 1748-1846. Lewisburg, Pennsylvania: Wennawoods Publishing, 1998.

"The Expedition of Major Clifton Wharton in 1844." Transactions of the Kansas State Historical Society, 16 (1923-1925).

Ford, Worthinton C., et al., eds., Journals of the Continental Congress, 1774-1789. 34 vols. Washington, D. C.: Government Printing Office, 1904-1937.

"Frontier Wars." Series U. vol. 23. Lymam C. Draper Manuscripts. Collections of the State Historical Society of Wisconsin. Microfilm. Wise Library. West Virginia University. 
“General Butler's Journal." In Neville B. Craig, ed., The Olden Time: A Monthly Publication Devoted to the Preservation of Documents and Other Authentic Information in Relation to the Early Explorations and the Settlement and Improvement of the Country Around the Head of the Ohio. 2 (1848). Reprinted. Cincinnati, Robert Clarke Co., 1876: 510-525.

“George Croghan's Journal.” ed. Nicholas B. Wainwright. The Pennsylvania Magazine of History and Biography 71 (Oct. 1947): 350-360.

Gipson, Lawrence Henry., ed., The Moravian Indian Mission on White River: Diaries and Letters, May 5, 1799, to November 12, 1806. Indianapolis: Indiana Historical Bureau, 1938.

Grinnell, George Bird. The Fighting Cheyennes. 1915. Reprinted. Norman: University of Oklahoma Press, 1956.

Grumet, Robert S., ed. Journey on the Forbidden Path: Chronicles of a Diplomatic Mission to the Allegheny Country, March-September, 1760. Philadelphia: American Philosophical Society, 1999.

- Voices from the Delaware Big House Ceremony. Norman: University of Oklahoma Press, 2001.

Hamilton, Charles, ed. Braddock's Defeat: The Journal of Captain Robert Chomley's BatmanThe Journal of a British Officer-Halkett's Orderly Book. Norman: University of Oklahoma Press, 1959.

Hamilton, Edward, ed. Adventures in the Wilderness: The American Journals of Louis Antoine de Bougainville, 1756-1760. Norman: University of Oklahoma Press, 1964.

Heckewelder, John. An Account of the History, Manners, and Customs of the Indian Nations, Who Once Inhabited Pennsylvania and the Neighboring States. 1819. Reprinted. Ed. William C. Reichel. Philadelphia: Memoirs of the Historical Society of Pennsylvania 12 (1876).

. A Narrative of the Mission of the United Brethren among the Delaware and Mohegan Indians, from Its Commencement in the Year 1740 to the Close of the Year 1808. Ed. William Elsey Connelley. 1820. Reprinted. Cleveland: The Burrows Brothers Company, 1907.

Hitakonanu'laxk (Tree Beard). The Grandfathers Speak: Native American Folk Tales of the Lenape' People. New York: Interlink Books, 1994.

Hollinger, David A. and Charles Capper, eds., The American Intellectual Tradition: Volume 1, 1630-1865. New York: Oxford University Press, 1993. 
Irving, John T. Indian Sketches Taken During an Expedition to the Pawnee Tribes. Philadelphia: Carey, Lea and Blanchard, 1835.

Irving, Washington. A Tour on the Prairies. 1835. Reprinted. New York: Time-Life Books Inc., 1980.

Jordan, John, ed. “James Kenny's 'Journal to ye Westward' 1758-1759.” The Pennsylvania Magazine of History and Biography 37 (1913): 295-449.

. "Journal of James Kenny, 1761-1763." The Pennsylvania Magazine of History and Biography 37 (1913): 1-47, 152-201.

"The Journals of Western Tours by Charles Frederick Post." In Reuben G. Thwaites, ed. Early Western Travels, 1748-1846. 32 vols. Cleveland: Arthur H. Clark, 1904-1908.

Kappler, Charles J., ed. Indian Treaties, 1778-1883. Washington, D. C.: Government Printing Office, 1904. . Indian Affairs: Laws and Treaties. 2 vols. Washington, D. C.: Government Printing Office, 1904

Kellogg, Louise Phelps, ed. Frontier Advance on the Upper Ohio, 1778-1779. Madison: Publications of the State Historical Society of Wisconsin, 1916.

. Frontier Retreat on the Upper Ohio, 1779-1781. Madison: Publications of the State Historical Society of Wisconsin, 1917.

Knopf, Richard C., ed. Anthony Wayne, A Name in Arms: The Wayne-Knox-PickeringMcHenry Correspondence. Pittsburgh: University of Pittsburgh Press, 1960.

Lemay, J. A. Leo, ed. Benjamin Franklin: Writings. New York: The Library of America, 1987.

"Letters From the Indian Missions in Kansas." Transactions of the Kansas State Historical Society. 16 (1923-1925).

Lindestrome, Peter. Geographia Americae with an Account of the Delaware Indians, Based on Surveys and Notes Made in 1654-1656. Amandus Johnson, trans. and ed. Philadelphia: Swedish Colonial Society, 1925.

Logan Papers. Philadelphia: American Philosophical Society.

Loskiel, George H. History of the Mission of the United Brethren Among Indians in North America in three parts. Christian Ignatius La Trobe, trans. 3 parts. London: The Brethren's Society, 1794. 
Mahr, August C., trans. and ed. "A Canoe Journey from the Big Beaver to the Tuscarawas in 1771: A Travel Diary of John Heckewelder." Ohio State Archaeological and Historical Quarterly 61 (1952): 283-298.

. “Zeisberger’s Schoenbrunn Diary, 1772-1777." Manuscript Collection. Columbus: Historical Society of Ohio.

. Schoenbrunn Story: Excerpts from the Diary of the Reverend David Zeisberger, 1772-1777 at Schoenbrunn in the Ohio Country. Columbus: Historical Society of Ohio, 1972.

Marx, Tilde.,trans. "Diaries of the Moravian Missions in Western Pennsylvania, 1769-1772." Merle Deardorff Papers. Warren Historical Society, Warren, Pennsylvania.

McClure, David. With notes by Franklin B. Dexter. Diary of David McClure: Doctor of Divinity, 1748-1820. New York: The Knickerbocker Press, 1899.

McCready, Robert. "A Revolutionary Journal and Orderly Book of General Lachlan McIntosh's Expedition, 1778." Edward G. Williams, ed. The Western Pennsylvania Historical Magazine 43 (March 1960): 17-31.***

Minutes of the Provincial Council of Pennsylvania From the Organization to the Termination of the Proprietary Government. 16 vols. Harrisburg, Pennsylvania. 1851-1852. Reprinted. New York: AMS Press, 1968

Morgan, George. Letter Books, 1769-1779. Pittsburgh: Carnegie Library.

Morgan, Lewis Henry. The Indian Journals: 1859-1862. Leslie A. White, ed. 1859. Reprinted. New York: Dover Publications Inc., 1993.

Morse, Jedediah. A Report to the Secretary of War of the United States on Indian Affairs. 1822. Reprinted. New York: Augustus M. Kelley Publishers, 1970.

Mulkearn, Lois, ed. George Mercer's Papers relating to the Ohio Company of Virginia. Pittsburgh: University of Pittsburgh Press, 1954.

Myers, Albert Cook, ed. Narratives of Early Pennsylvania, West New Jersey, and Delaware, 1630-1710. Original Narratives of Early American History Series. New York: Charles Scribner's Sons, 1912.

William Penn His Own Account of the Lenni Lenape or Delaware Indians, 1683. Moylan: Pennsylvania, 1937. Reprinted. Tercentenary Edition. Wilmington, Delaware: The Middle Atlantic Press, 1970.

"Narrative of John Brickell's Captivity Among the Delaware Indians." The American Pioneer: A Monthly Periodical. 2 vols. Cincinnati, Ohio: Edited and Published by John S. Williams, (1844) 2: 46-52. 
The New American State Papers, 1789-1860: Indian Affairs. vol. 4. Northwest.

Thomas C. Cochran, gen. ed. Wilmington, Delaware: Scholarly Resources, Inc., 1972.

O'Callaghan, E. B., ed.. Documents Relative to the Colonial History of the State of New York. 15 vols. Albany, New York: Weed, Parsons, and Co., 1856-1887.

. The Documentary History of the State of New York. 4 vols. Albany, New York: Weed, Parsons, and Co., 1856-1857.

O’Donnell, James H., ed. "Captain Pipe's Speech: A Commentary on the Delaware Experience, 1775-1781." Northwest Ohio Quarterly 64 (1992): 126-133.

Padover, Saul K., ed. The Washington Papers. New York: Harper and Brothers Publishers, 1955.

Penn Letter Books. 4. Philadelphia: Historical Society of Pennsylvania.

Penn Manuscripts of Indian Affairs 1. Philadelphia: Historical Society of Pennsylvania.

Pennsylvania Archives. 1st series, 12 vols. Samuel Hazard, ed. Philadelphia: Joseph Severns and Company, 1851-1852.

Pennsylvania Archives. 2nd series, 12 vols. John Blinn and William Egle, eds. Harrisburg: E. K. Myers, State Printer, 1891-1896.

Pennsylvania Archives. 4th series, 12 vols. George Reed, ed. Harrisburg: The State of Pennsylvania Printer, 1900.

Post, Charles Frederick. "Two Journals of Western Tours, by Charles Frederick Post: One to the Neighborhood of Fort Duquesne (July-September, 1758); the Other, to the Ohio (October 1758-January, 1759).” In Early Western Travels, 1748-1846. Reuben Gold Thwaites, ed. 1: 175-291. Cleveland: Arthur H. Clark, 1904.

"Post's Journal, 1758." In I. D. Rupp, ed. Early History of Pennsylvania, and of the West, and of Western Expeditions and Campaigns from MDCCLIV to MDCCCXXXIII. 1846. Reprinted. Lewisburg, Pennsylvania: Wennawoods Publishing, 1995.

Prucha, Francis Paul, ed., Documents of United States Indian Policy. 3rd ed. Lincoln: University of Nebraska Press, 2000.

Rhodehamel, John., ed. George Washington: Writings. New York: The Library of America, 1997.

Rupp I.D., ed. Early History of Pennsylvania, and of the West, and of Western Expeditions and Campaigns from MDCCLIV to MDCCCXXXIII. 1846. Reprinted. Lewisburg, Pennsylvania: Wennawoods Publishing, 1995. 
Schechter, Stephen L., ed. Roots of the Republic: American Founding Documents Interpreted. Madison, Wisconsin: Madison House, 1990.

Schweinitz, Edmund de, ed. "The Narrative of Marie Le Roy and Barbara Leininger, For Three Years Captives among the Indians.” The Pennsylvania Magazine of History and Biography 29 (1905): 407-420.

“The Second Journal of Christian Frederick Post Oct. 25, 1758 to Jan. 10, 1759.” In I. D. Rupp., ed. Early History of Pennsylvania, and of the West, and of Western Expeditions and Campaigns from MDCCLIV to MDCCCXXXIII. 1846. Reprinted. Lewisburg, Pennsylvania: Wennawoods Publishing, 1995.

Sipe, C. Hale, ed. Fort Ligonier and Its Times. 1932. Reprinted. New York: Arno Press and The New York Times, 1971.

Smith, William. A Brief State of the Province of Pennsylvania. London: R. Griffiths, 1756.

. Expedition Against the Ohio Indians. 1765. Facsimile. Ann Arbor, Michigan: University Microfilms, Inc., 1966.

Soderlund, Jean, ed. William Penn and the Founding of Pennsylvania, 1680-1684: $\underline{A}$ Documentary History. Philadelphia: University of Pennsylvania Press, 1983.

St. Clair, Arthur. Narrative of The Campaign Against the Indians, 1791. Salem, New Hampshire: Ayer Company, Publishers, Inc., 1991.

Stevens, Sylvester K., ed. The Wilderness Chronicles of Northwestern Pennsylvania. Harrisburg: Pennsylvania Historical and Museum Commission, 1941.

Stevens, Sylvester K. and Donald H. Kent, et al., eds. The Papers of Colonel Henry Bouquet. 19 vols. Harrisburg: Pennsylvania Historical and Museum Commission, 1940.

. The Papers of Henry Bouquet 5 vols. Harrisburg: Pennsylvania Historical and Museum Commission, 1951.

Sullivan, James, et al., eds. The Papers of Sir William Johnson. 14 vols. Albany: State University of New York, 1921-1965.

The Territorial Papers of the United States. Clarence Edwin Carter, comp. and ed. The Territory Northwest of the River Ohio, 1787-1803. 5 vols. Washington, D. C.: United States Government Printing Office, 1934.

Thomson, Charles. An Inquiry into the Causes of the Alienation of the Delaware and Shawnee Indians From the British Interests. 1759. Reprinted. Philadelphia: John Campbell, 1867. 
Thornbrough, Gayle, ed., Letter Book of the Indian Agency at Fort Wayne, 1809-1815. Indianapolis: Indiana Historical Society, 1961.

Thwaites, Reuben Gold, ed. Chronicles of Border Warfare with Reflections, Anecdotes, \&c. by Alexander Scott Withers. 1831. Reprinted. Cincinnati: Stewart \& Kidd Company Publishers, 1895.

Thwaites, Reuben Gold and Louise Phelps Kellogg, eds. Documentary History of Dunmore's War, 1774. Madison: Publications of the State Historical Society of Wisconsin, 1905.

. The Revolution on the Upper Ohio, 1775-1777. Madison: Publications of the State Historical Society of Wisconsin, 1908. Reprinted. Port Washington, New York: Kennikat Press, 1970.

. Frontier Defense on the Upper Ohio, 1777-1778. Madison: Publications of the State Historical Society of Wisconsin, 1912.

“The Treaty of Logg's Town, 1752." Virginia Magazine of History and Biography 13 (1905-1906): 148-174.

Volwiler, A. T., ed. "William Trent's Journal at Fort Pitt, 1763." Mississippi Valley Historical Review 11 (March-June 1924): 390-413.

Wallace, Paul A. W., ed. Thirty Thousand Miles With John Heckewelder. Pittsburgh: University of Pittsburgh Press, 1958. Reprinted as The Travels of John Heckewelder in Frontier America. Pittsburgh: University of Pittsburgh Press, 1985.

Washington, George. The Diaries of George Washington, 1748-1794. John C. Fitzpatrick, ed. 4 vols. Boston: Houghton Mifflin Co., 1925.

. The Journal of Major George Washington: An Account of His First Official Mission, Made as Emissary from the Governor of Virginia to the Commandant of the French Forces on the Ohio, October 1753-January 1754. Williamsburg, Virginia: Facsimile Edition, Published by the Colonial Williamsburg Foundation, 1959.

Wedel, Waldo., ed., The Dunbar-Allis Letters on the Pawnee. New York: Garland Publishing, Inc., 1985.

Wellenreuther, Hermann and Carol Wessel, eds. Hernhutter Indianermission in der Amerikanischen Revolution, Die Tagebucher von David Zeisberger, 1772-1781. Berlin: Akademie Verlag, 1995.

Whritenour, Raymond. A Delaware-English Lexicon of Words and Phrases. Butler, New Jersey: Lenape Texts \& Studies, 1995. 
Zeisberger, David. "History of the Northern American Indians." Nathaniel Schwarze, trans. Archer Butler Hulbert, ed. Ohio State Archaeological and Historical Quarterly 19: 1-2 (Jan. and April, 1910): 1-189.

\section{BIBLIOGRAPHY}

\section{$\underline{\text { Secondary Works }}$}

Abernathy, Thomas Perkins. Western Lands and the American Revolution. New York: D. Appleton-Century Company, 1938.

Adams, Richard C. Ancient Religion of the Delaware Indians and Observations and Reflections. Washington, D. C.: The Law Reporter Printing Co., 1904.

. The Delaware Indians: A Brief History. 1906. Reprinted. Saugerties, New York: Hope Farm Press, 1995.

. Legends of the Delaware Indians and Picture Writing. Deborah Nichols, ed. Syracuse: Syracuse University Press, 1997.

Agnew, Brad. Fort Gibson: Terminal on the Trail of Tears. Norman: University of Oklahoma Press, 1980.

Allen, Paula Gunn. The Sacred Hoop: Recovering the Feminine in American Indian Traditions. Boston: Beacon Press, 1986.

Anderson, Fred. Crucible of War: The Seven Years' War and the Fate of Empire in British North America, 1754-1766. New York: Alfred A. Knopf, 2000.

Aquila, Richard. The Iroquois Restoration: Iroquois Diplomacy on the Colonial Frontier, 17011754. 1983. Reprinted. Lincoln: University of Nebraska Press, 1997.

Axtell, James. The Invasion Within: The Contest of Cultures in Colonial North America. New York: Oxford University Press, 1985.

Beauchamp, William M, ed. The Life of Conrad Weiser, As It Relates to His Services as Official Interpreter between New York and Pennsylvania and as Envoy between Philadelphia and the Onondaga Councils. Syracuse: New York: The Onondaga Historical Association, 1925.

Bemis, Samuel Flagg. Jay's Treaty: A Study in Commerce and Diplomacy. New York: The Macmillan Company, 1924 
Brinton, Daniel. The Lenape and Their Legends: With the Complete Text and Symbols of the Walum Olum. 1884. Reprinted. New York: AMS Press, Inc., 1969.

Calloway, Colin G. Crown and Calumet: British-Indian Relations, 1783-1815. Norman: University of Oklahoma Press, 1987.

- The American Revolution in Indian Country: Crisis and Diversity in Native American Communities. New York: Cambridge University Press, 1995.

. New Worlds For All: Indians, Europeans, and the Remaking of Early America. Baltimore: The Johns Hopkins University Press, 1997.

. First Peoples: A Documentary Survey of American Indian History. Boston: Bedford/St. Martin's, 1999.

Cayton, Andrew R. L. Frontier Indiana. Bloomington: Indiana University Press, 1996.

Cayton, Andrew R. L. and Fredrika J. Teute, eds. Contact Points: American Frontiers from the Mohawk Valley to the Mississippi, 1750-1830. Chapel Hill: University of North Carolina Press, 1998.

Cooper, James Fenimore. The Last of the Mohicans: A Narrative of 1757. vol 1. book 2. In The Leatherstocking Tales. 1826. Reprinted. New York: The Library of America, 1985.

Davidson, Robert L. D. War Comes to Quaker Pennsylvania, 1682-1756. New York: Columbia University Press, 1957.

Doddridge, Joseph. Notes on the Settlement and Indian Wars of the Western Parts of Virginia and Pennsylvania from 1763-1783. 1912. Reprinted. Bowie, Maryland: Heritage Books, Inc., 1983.

Dowd, Gregory Evans. A Spirited Resistance: The North American Indian Struggle For Unity, 1745-1815. Baltimore: The Johns Hopkins University Press, 1992.

- War Under Heaven: Pontiac, the Indian Nations \& the British Empire. Baltimore: The Johns Hopkins University Press, 2002.

Downes, Randolph C. Council Fires on the Upper Ohio: A Narrative of Indian Affairs in the Upper Ohio Valley until 1795. 1940. Reprinted. Pittsburgh: University of Pittsburgh Press, 1969.

. Frontier Ohio, 1788-1803. Ohio Historical Collections, Vol. III. Columbus: The Ohio State Archaeological and Historical Society, 1935

Dunn, Richard S. and Mary Maples Dunn, eds. The World of William Penn. Philadelphia: University of Pennsylvania Press, 1986. 
Eckert, Allan W. Wilderness Empire: A Narrative. Boston: Little, Brown and Company, 1969. . A Sorrow in Our Heart: The Life of Tecumseh. New York: Bantam Books, 1992.

- That Dark and Bloody River: Chronicles of the Ohio River Valley. New York: Bantam Books, 1995.

Edmunds, R. David. The Shawnee Prophet. Lincoln: University of Nebraska Press, 1983.

Elkins, Stanley and Eric McKitrick. The Age of Federalism: The Early American Republic, 17881800. New York: Oxford University Press, 1993.

Fenton, William N. The Great Law and the Longhouse: A Political History of the Iroquois Confederacy. Norman: University of Oklahoma Press, 1998.

Flexner, James Thomas. Mohawk Baronet: Sir William Johnson of New York. New York: Harpers and Brothers, 1959.

Foreman, Grant. Advancing the Frontier, 1830-1860. Norman: University of Oklahoma Press, 1933.

. The Last Trek of the Indians. Chicago: University of Chicago Press, 1946.

Gray, Elma E. and Leslie Robb Gray. Wilderness Christians: The Moravian Mission to the Delaware Indians. Ithaca, New York: Cornell University Press, 1956.

Grinde, Donald A. Jr. The Iroquois and the Founding of the American Nation. San Francisco: The Indian Historian Press, Inc., 1977.

Hamilton, Milton W. Sir William Johnson: Colonial American, 1715-1763. Port Washington, New York: Kennikat National University Publications, 1976.

Hanna, Charles. The Wilderness Trail or The Ventures and Adventures of the Pennsylvania Traders on the Allegheny Path. 2 vols. New York: G. P. Putnam's Sons, 1911.

Henretta, James A. and Gregory H. Nobles, eds. Evolution and Revolution: American Society, 1600-1820. Lexington, Massachusetts: D. C. Heath and Company, 1987.

Hinderaker, Eric. Elusive Empires: Constructing Colonialism in the Ohio Valley, 1673-1800. New York: Cambridge University Press, 1997.

Hoig, Stan. The Cheyenne. New York: Chelsea House Publishers, 1989.

Horsman, Reginald. Expansion and American Indian Policy, 1783-1812. East Lansing: Michigan State University Press, 1967. 
Hoxie, Frederick E., Ronald Hoffman, and Peter J. Albert, eds. Native Americans and the Early Republic. Charlottesville: The University Press of Virginia, 1999.

Hurt, R. Douglas. The Ohio Frontier: Crucible of the Old Northwest, 1720-1830. Bloomington: Indiana University Press, 1996.

Isenberg, Andrew C. The Destruction of the Bison: An Environmental History, 1750-1920. New York: Cambridge University Press, 2000.

Jacobs, Wilbur R. Diplomacy and Indian Gifts: Anglo-French Rivalry along the Ohio and Northwest Frontier, 1748-1763. Stanford, California: Stanford University Press, 1950.

Jennings, Francis. The Ambiguous Iroquois Empire: The Covenant Chain Confederation of Indian Tribes with English Colonies from its beginnings to the Lancaster Treaty of 1744. New York: W. W. Norton \& Company, 1984.

. Empire of Fortune: Crowns, Colonies, \& Tribes in the Seven Years' War in America. New York: W. W. Norton \& Company, 1988.

Jennings, Francis, William N. Fenton, et al., eds. The History and Culture of Iroquois Diplomacy: An Interdisciplinary Guide to the Treaties of the Six Nations and Their League. Syracuse, New York: Syracuse University Press, 1985.

Jensen, Merrill. The New Nation: A History of the United States during the Confederation. New York: Alfred A. Knopf, 1950.

Kelsay, Isabel Thompson. Joseph Brant, 1743-1807: Man of Two Worlds. Syracuse: Syracuse University Press, 1984.

Kent, Donald H., ed. The French Invasion of Western Pennsylvania. Harrisburg: Pennsylvania Historical and Museum Commission, 1954.

Kohn, Richard H. Eagle and Sword: The Federalists and the Creation of the Military Establishment in America, 1783-1802. New York: The Free Press, A Division of Macmillan Brothers Publishers, 1975.

Kopperman, Paul E. Braddock on the Monongahela. Pittsburgh: University of Pittsburgh Press, 1977.

Kraft, Herbert C., ed. A Delaware Indian Symposium. Harrisburg: The Pennsylvania Historical and Museum Commission, 1974. Anthropological Series Number 4. Barry C. Kent, gen. ed..

. The Lenape: Archaeology, History, and Ethnography. Newark: New Jersey Historical Society, 1986. 
Krech III, Shepard. Indians, Animals, and the Fur Trade: A Critique of "Keepers of the Game." Athens: University of Georgia Press, 1981.

Lavender, David. Bent's Fort. New York: Garden City: Doubleday \& Company, Inc., 1954.

Lewis, Thomas A. For King and Country: The Maturing of George Washington, 1748-1760. New York: Harper Collins Publishers, 1993.

Lustig, Mary Lou. The Imperial Executive in America: Sir Edmund Andros, 1637-1714. Madison, New Jersey: Fairleigh Dickinson University Press, 2002.

Martin, Calvin. Keepers of the Game: Indian-Animal Relationships and the Fur Trade. Berkeley: University of California Press, 1978.

McConnell, Michael N. A Country Between: The Upper Ohio Valley and Its Peoples, 17241774. Lincoln: University of Nebraska Press, 1992.

McCutchen, David.. trans., The Red Record, The Wallam Olum: The Oldest Native North American History. Garden City Park, New York: Avery Publishing Group Inc., 1993.

Merrell, James H. The Indians' New World: Catawbas and Their Neighbors from European Contact through the Era of Removal. Chapel Hill: University of North Carolina Press, 1989

. Into the Woods: Negotiators on the Pennsylvania Frontier. New York: W. W. Norton \& Company, 1999.

Merritt, Jane T. At the Crossroads: Indians and Empires on a Mid-Atlantic Frontier, 1700-1763. Chapel Hill: University of North Carolina Press, 2003.

Miner, Craig H. and William E. Unrau. The End of Indian Kansas: A Study of Cultural Revolution, 1854-1871. Lawrence: University Press of Kansas, 1978.

Mohr, Walter H. Federal Indian Relations, 1774-1788. Philadelphia: University of Pennsylvania Press, 1933.

Moore, John H. The Cheyenne Nation: A Social and Demographic History. Lincoln: University of Nebraska Press, 1987.

Morgan, Edmund S. The Birth of the Republic, 1763-1789. Chicago: The University of Chicago Press, 1977.

Morgan, Lewis Henry. League of the Ho-de-no-sau-nee, Iroquois. 1851. Reprinted. New York: Corinth Books, 1962. 
Morgan, Ted. Wilderness At Dawn: The Settling of the North America Continent. New York: Simon \& Schuster, 1993.

Nester, William R. "Haughty Conquerors": Amherst and the Great Indian Uprising of 1763. Westport, Connecticut: Praeger, 2000.

Newcomb Jr., William W. The Culture and Acculturation of the Delaware Indians. Ann Arbor: Anthropological Paper no. 10 of the Museum of Anthropology, University of Michigan, 1956.

Norton, Thomas Elliot. The Fur Trade in Colonial New York, 1686-1776. Madison: University of Wisconsin Press, 1974.

O'Brien, Sharon. American Indian Tribal Governments. Norman: University of Oklahoma Press, 1989.

Olmstead, Earl P. Blackcoats Among the Delaware: David Zeisberger on the Ohio Frontier. Kent, Ohio: The Kent State University Press, 1991. . David Zeisberger: A Life Among the Indians. Kent, Ohio: The Kent State University Press, 1997.

O’Meara, Walter. Guns At The Forks. Englewood Cliffs, New Jersey: Prentice-Hall Inc., 1965.

Parker, Arthur C. The Constitution of the Five Nations or the Iroquois Book of the Great Law. Albany: New York State Museum, Bulletin No. 184 (1916).

Parkman, Francis. The Conspiracy of Pontiac. 1851. Reprinted. New York: The Library of America, 1991.

. The Oregon Trail. 1876. Reprinted. Garden City, New York: Doubleday \& Company, Inc., 1946.

. France and England in North America. 2 vols. 1885. Reprinted. New York: The Library of America, 1983.

Pearce, Roy Harvey. Savagism and Civilization: A Study of the Indian and the Idea of Civilization. Baltimore: The John Hopkins Press, 1953.

Peckham, Howard. Pontiac and the Indian Uprising. New York: Russell and Russell, 1947.

Prucha, Francis Paul. American Indian Policy in the Formative Years: The Indian Trade and Intercourse Acts, 1790-1835. 1962. Reprinted. Lincoln: University of Nebraska Press, 1970. . American Indian Treaties: The History of a Political Anomaly. Berkeley: University of 


\section{California Press, 1994.}

Richter, Daniel, K. The Ordeal of the Longhouse: The Peoples of the Iroquois League in the Era of European Colonization. Chapel Hill: University of North Carolina Press, 1992.

Richter, Daniel K. and James H. Merrell, eds. Beyond the Covenant Chain: The Iroquois and Their Neighbors in Indian North America, 1600-1800. Syracuse, New York: Syracuse University Press, 1987.

Rollings, Willard H. The Osage: An Ethnohistorical Study of Hegemony on the Prairie-Plains. Columbia: University of Missouri Press, 1992.

Savelle, Max. George Morgan: Colony Builder. New York: Columbia University Press, 1932.

Schaaf, Gregory. Wampum Belts \& Peace Trees: George Morgan, Native Americans, and Revolutionary Diplomacy. Golden, Colorado: Fulcrum Publishing, 1990.

Schonenberger, Regula Trenkwalder. Lenape Women, Matriliny, and the Colonial Encounter: Resistance and Erosion of Power (c. 1600-1876). Bern, Switzerland: Peter Lang, Inc., European Academic Publishers, 1991.

Sheehan, Bernard W. Seeds of Extinction: Jeffersonian Philanthropy and the American Indians. Chapel Hill: University of North Carolina Press, 1973.

Sipe, C. Hale. The Indian Chiefs of Pennsylvania. Butler, Pennsylvania: The Ziegler Printing Co., Inc., 1927.

. The Indian Wars of Pennsylvania. 1931. Reprinted. Lewisburg, Pennsylvania: Wennawoods Publishing, 1995.

Slaughter, Thomas P. The Whiskey Rebellion: Frontier Epilogue to the American Revolution. New York: Oxford University Press, 1987.

Slotkin, Richard. Regeneration Through Violence: The Mythology of the American Frontier, 1600-1800. Middletown, Connecticut: Wesleyan University Press, 1973.

Steele, Ian K. Warpaths: Invasions of North America. New York: Oxford University Press, 1994.

Sosin, Jack M. Whjtehall and the Wilderness: The Middle West in British Colonial Policy, 17601775. Lincoln: University of Nebraska Press, 1961.

Speck, Frank G. A Study of the Delaware Indian Big House Ceremony: In Native Text Dictated by Witapanoxwe. Harrisburg: Publication of the Pennsylvania Historical Commission, 1931.

Steele, Ian K. Warpaths: Invasions of North America. New York: Oxford University Press, 1994. 
Sugden, John. Blue Jacket: Warrior of the Shawnees. Lincoln: University of Nebraska Press, 2000.

Swanton, John R., ed. The Indian Tribes of North America. Bulletin 145. Washington, D. C.: Bureau of American Ethnology, 1952.

Sword, Wiley. President Washington's Indian War: The Struggle For the Old Northwest, 17901795. Norman: University of Oklahoma Press, 1985.

Tanner, Helen Hornbeck, ed. Atlas of Great Lakes Indian History. Norman: University of Oklahoma Press, 1987.

Taylor, Alan. William Cooper's Town. New York: Alfred A. Knopf, 1995.

Thayer, Theodore. Israel Pemberton, King of the Quakers. Philadelphia: University of Pennsylvania Press, 1943.

Tolles, Frederick B. James Logan and the Culture of Provincial America. Boston: Little, Brown and Company, 1957.

Wainwright, Nicholas B. George Croghan: Wilderness Diplomat. Chapel Hill: University of North Carolina Press, 1959.

Waldman, Carl. Atlas of the North American Indian. New York: Facts on File Publications, 1985.

Wallace, Anthony F. C. King of the Delawares: Teedyuscung, 1700-1763. 1945. Reprinted. Syracuse: Syracuse University Press, 1990.

. With the assistance of Sheila C. Steen. The Death and Rebirth of the Seneca. New York: Alfred A. Knopf, 1970.

. Jefferson and the Indians: The Tragic Fate of the First Americans. Cambridge, Massachusetts: The Belknap Press of Harvard University, 1999

Wallace, Paul A.W. Conrad Weiser, 1696-1760: Friend of Colonist \& Mohawk. 1945. Reprinted. Lewisburg: Pennsylvania, Wennawoods Publishing, 1996. . Indians in Pennsylvania. Second Edition. Revised by William A. Hunter. Harrisburg: Commonwealth of Pennsylvania Historical and Museum Commission, 1993.

. The White Roots of Peace: The Iroquois Book of Life. 1946. Reprinted. Santa Fe, New Mexico: Clear Light Publishers, 1994. 
Ward, Harry M. The Department of War, 1781-1795. Pittsburgh: University of Pittsburgh Press, 1962.

. "Unite or Die": Intercolony Relations 1690-1763. Port Washington, New York: Kennikat Press, 1971.

Webb, Stephen Saunders. 1676: The End of American Independence. Syracuse: Syracuse University Press, 1984.

Weslager, C. A. In collaboration with A. R. Dunlap. Dutch Explorers, Traders and Settlers in the Delaware Valley, 1609-1664. Philadelphia: University of Pennsylvania Press, 1961.

Weslager, C. A. The English on the Delaware: 1610-1682. New Brunswick, New Jersey: Rutgers University Press, 1967.

. The Delawares: A History. New Brunswick, New Jersey: Rutgers University Press, 1972.

. The Delaware Indian Westward Migration. Wallingford, Pennsylvania: The Middle Atlantic Press, 1978.

West, Martin., ed. War For Empire in Western Pennsylvania. Harrisburg: Pennsylvania Historical and Museum Commission, 1993.

Wheeler-Voegelin, Erminie. Indians of Ohio and Indiana Prior to 1795: Ethnohistory of Indian Use and Occupancy in Ohio and Indiana Prior to 1795. New York: Garland Publishing Inc., 1974.

White, Richard. The Middle Ground: Indians, Empires, and Republics in the Great Lakes Region, 1650-1815. New York: Cambridge University Press, 1991.

Williams, Edward G. Fort Pitt and the Revolution on the Western Frontier. Pittsburgh: Historical Society of Western Pennsylvania, 1978.

Wood, Gordon S. The Creation of the American Republic, 1776-1787. Chapel Hill: University of North Carolina Press, 1969.

Zornow, William Frank. Kansas: A History of the Jayhawk State. Norman: University of Oklahoma Press, 1957. 


\section{BIBLIOGRAPHY}

\section{$\underline{\text { Articles and Chapters }}$}

Barsh, Russel Lawrence. "The Nature and Spirit of North American Political Systems." American Indian Quarterly 10 (Summer 1986): 181-198.

Becker, Marshall J. “The Okehocking: A Remnant Band of Delaware Indians.” Pennsylvania Archaeologist 46 (1976): 24-61.

. "The Boundary Between the Lenape and Munsee: The Forks of the Delaware as a Buffer Zone." Man in the Northeast 26 (1983): 1-20.

." The Lenape Bands Prior to 1740: The Identification of Boundaries and the Processes of Change Leading to the Formation of the 'Delawares."' In Herbert C. Kraft. ed. The Lenape Indian: A Symposium. Archaeological Research Center, Seton Hall University, Publication 7. South Orange, New Jersey: Seton Hall University, 1984: 19-32.

Bilharz, Joy. "First Among Equals?: The Changing Status of Seneca Women." In Laura F. Klein and Lillian A. Ackerman, eds., Women and Power in Native North America. Norman: University of Oklahoma Press, 1995.

Bridenbaugh, Carl. "The Old and New Societies of the Delaware Valley in the Seventeenth Century." The Pennsylvania Magazine of History and Biography 100 (1976): 143-172.

Buck, William J. "Lappawinzo and Tishcohan: Chiefs of the Lenni Lenape." The Pennsylvania Magazine of History and Biography 7 (1883): 215-218.

Calloway, Colin G. "The Inter-tribal Balance of Power on the Great Plains, 1760-1850." Journal of American Studies 16 (April 1982: 25-47.

Champagne, Duane. "The Delaware Revitalization Movement of the Early 1760s: A Suggested Reinterpretation.” American Indian Quarterly 12 (Spring 1988): 107-126.

Champion, Walter C. "Christian Frederick Post and the Winning of the West." The Pennsylvania Magazine of History and Biography 104 (July 1980): 308-325.

Christianson, James B. "Early Osage_-'The Ishmaelites of the Savages.', Kansas History. 11 (Spring 1988): 15-33.

Dickason, Olive Patricia. "Huron / Wyandot." In Frederick E. Hoxie, ed. Encyclopedia of North American Indians. Boston: Houghton Mifflin Company, 1996.

Dowd, Gregory E. “Thinking and Believing: Nativism and Unity in the Ages of Pontiac and 
Tecumseh.” In Roger L. Nichols, ed. The American Indian: Past and Present. Boston: McGraw Hill, 1999

Edmunds, R. David. “'A Watchful Safeguard to our Habitations': Black Hoof and the Loyal Shawnees.” In Frederick E. Hoxie et al., eds. Native Americans and the Early Republic. Charlottesville: The University Press of Virginia, 1999.

Foster, Michael K. "Another Look at the Function of Wampum in Iroquois-White Councils." In Daniel K. Richter and James H. Merrell, eds. Beyond the Covenant Chain: The Iroquois and Their Neighbors in Indian North America, 1600-1800. Syracuse, New York: Syracuse University Press, 1987.

Fur, Gunlog. “'Some Women Are Wiser than Some Men': Gender and Native American History." In Nancy Shoemaker, ed., Theorizing the Past in Native American Studies. New York: Routledge, 2002.

Goddard, Ives. "Delaware." In Handbook of North American Indians. gen. ed. William C. Sturtevant. vol. 15. Northeast. ed. Bruce Trigger. Washington D. C.: Smithsonian Institution Press, 1978: 622-635.

Hamilton, Kenneth G. "Cultural Contributions of Moravian Missions among the Indians." Pennsylvania History, Quarterly Journal of the Pennsylvania Historical Association 17 (1951): $1-15$.

Hewitt, J. N. B. "Tuscarora." In Handbook of American Indians North of Mexico. Frederick W. Hodge, ed. Bulletin, U. S. Bureau of American Ethnology, 30 Part two. Washington, D.C.: Smithsonian Institution, 1910.

Horsman, Reginald. "The British Indian Department and The Abortive Treaty of Lower Sandusky, 1793.” The Ohio Historical Quarterly 52 (July 1961): 184-190.

Howard, Dresden W. H. "The Battle of Fallen Timbers as Told by Chief Kin-Jo-I-No." Northwest Ohio Quarterly 20 (1941): 40- 47.***

Hunter, William A. "Provincial Negotiations with the Western Indians, 1754-1758." Pennsylvania History, Quarterly Journal of the Pennsylvania Historical Association 18 (July 1951): 338-350.

. "The Ohio, The Indian's Land.” Pennsylvania History, Quarterly Journal of the Pennsylvania Historical Association 21 (1954): 338-350.

. "Victory at Kittanning." Pennsylvania History, Quarterly Journal of the Pennsylvania Historical Association 23 (July 1956): 3-34

. "A Note on the Unalachtigo." In Herbert C. Kraft, ed. A Delaware Indian Symposium. Harrisburg: The Pennsylvania Historical and Museum Commission, 1974. 
. "Documented Sub Divisions of the Delaware Indians." Bulletin of the Archaeological Society of New Jersey 35 (1978): 1-23.

Jennings, Francis. “The Delaware Interregnum.” Pennsylvania Magazine of History and Biography 89 (April 1965): 165-181.

. "Glory, Death, and Transfiguration: The Susquehannock Indians in the Seventeenth Century." Proceedings of the American Philosophical Society 112 (Feb. 1968): 15-53.

. "The Delaware Indians in the Covenant Chain.” In Herbert C. Kraft, ed. A Delaware Indian Symposium. Harrisburg: The Pennsylvania Historical and Museum Commission, 1974.

. "Susquehannock." In Handbook of North American Indians William C. Sturtevant, gen. ed., vol. 15. Northeast. Bruce Trigger,ed. 362-367. Washington D. C.: Smithsonian Institution Press, 1978.

. "Brother Miquon: Good Lord!.” In Richard S. Dunn and Mary Maples Dunn, eds. The World of William Penn. Philadelphia: University of Pennsylvania Press, 1986.

. "Pennsylvania Indians and the Iroquois." In Daniel K. Richter and James H. Merrell, eds. Beyond the Covenant Chain: The Iroquois and Their Neighbors in Indian North America, 1600-1800. Syracuse, New York: Syracuse University Press, 1987

Kraft, Herbert C. “The Northern Lenape in Prehistoric and Early Colonial Times.” In Herbert C. Kraft. ed. The Lenape Indian: A Symposium. Archaeological Research Center, Seton Hall University, Publication 7. South Orange, New Jersey: Seton Hall University, 1984.

Maltz, Daniel and Joallyn Archambault. "Gender and Power in Native North America," In Laura F. Klein and Lillian A. Ackerman, eds., Women and Power in Native North America. Norman: University of Oklahoma Press, 1995.

Mann, Barbara Alice. "Epilogue: Euro-Forming the Data." In Bruce E. Johansen, ed., Debating Democracy: Native American Legacy of Freedom. Santa Fe, New Mexico: Clear Light Publishers, 1998.

. “I Hope You Will Not Destroy What I Have Saved': Hopocan before the British Tribunal in Detroit, 1781.” In Barbara Alice Mann, ed. Native American Speakers of the Eastern Woodlands: Selected Speeches and Critical Analyses. Westport, Connecticut: Greenwood Press, 2001.

McConnell, Michael N. "Peoples 'In Between': The Iroquois and the Ohio Indians, 1720-1768." In Daniel K. Richter and James H. Merrell, eds. Beyond the Covenant Chain: The Iroquois and Their Neighbors in Indian North America, 1600-1800. Syracuse, New York: Syracuse University Press, 1987. 
. "Kuskusky Towns and Early Western Pennsylvania Indian History, 1748-1778."

The Pennsylvania Magazine of History and Biography 116 (Jan. 1992): 33-58.

McCoy, John C. "Survey Of Kansas Indian Lands." Transactions of the Kansas State Historical Society 4 (1886-1888).

Merritt, Jane T. "Dreaming of the Savior's Blood: Moravians and the Indian Great Awakening in Pennsylvania." The William and Mary Quarterly 54 (Oct. 1997): 1723-1746.

. "Language and Power on the Pennsylvania Frontier." In Andrew R. L. Cayton. and Fredrika J. Teute, eds. Contact Points: American Frontiers from the Mohawk Valley to the Mississippi, 1750-1830. Chapel Hill: University of North Carolina Press, 1998.

Merrell, James H. "Shickellamy, 'a Person of Consequence." In Robert S. Grumet, ed. Northeastern Indian Lives, 1632-1816. Amherst: University of Massachusetts Press, 1996.

. "Shamokin, 'the very seat of the Prince of darkness': Unsettling the Early American Frontier.” In Andrew R. L. Cayton. and Fredrika J. Teute, eds. Contact Points: American Frontiers from the Mohawk Valley to the Mississippi, 1750-1830. Chapel Hill: University of North Carolina Press, 1998.

- "American Nations, Old and New: Reflections on Indians and the Early Republic.” In Frederick E. Hoxie et al., ed. Native Americans and the Early Republic. Charlottesville: The University Press of Virginia, 1999.

Miller, Jay. "The Delaware as Women: A Symbolic Solution.” American Ethnologist 1 (August 1974): 507-514.

. “The Unalachtigo?.” Pennsylvania Archaeologist 44 (December 1974): 6-8.

. "Kwulakan: The Delaware Side of Their Movement West." Pennsylvania Archaeologist 45 (1975): 44-47.

. "Delaware." In Frederick Hoxie, ed. Encyclopedia of North American Indians. Boston: Houghton Mifflin Company, 1996.

Myers Jr., James P. "Pennsylvania’s Awakening: The Kittanning Raid of 1756.” Pennsylvania History: A Journal of Mid-Atlantic Studies 66 (Summer 1999): 399-420.

Ostreicher, David M. "Unmasking the Walum Olum: A 19th Century Hoax.” Bulletin of the Archaeological Society of New Jersey 49 (1994): 1-44. 
Shoemaker, Nancy. "An Alliance between Men: Gender Metaphors in Eighteenth-Century American Indian Diplomacy East of the Mississippi.” Ethnohistory 42 (Spring 1999): 239-263.

Smith, Dwight L. "Wayne's Peace With the Indians of the Old Northwest, 1795." The Ohio State Archaeological and Historical Quarterly 59 (July 1950): 239-255.

Speck, Frank G. "The Delaware Indians as Women: Were the Original Pennsylvanians Politically Emasculated?" The Pennsylvania Magazine of History and Biography 70 (Oct. 1946): $377-389$.

Spencer, Joab. "The Shawnee Indians: Their Customs, Traditions and Folk-Lore.” Transactions of the Kansas State Historical Society 10 (1907-1908).

Sugrue, Thomas. "The Peopling and Depeopling of Early Pennsylvania: Indians and Colonists, 1680-1720." The Pennsylvania Magazine of History and Biography 116 (Jan. 1992): 130.

Tanner, Helen Hornbeck. "The Glaize in 1792: A Composite Indian Community.” Ethnohistory 25 (Winter 1978): 15-40.

Thayer, Theodore. “The Quaker Party of Pennsylvania, 1755-1765.” The Pennsylvania Magazine of History and Biography 71 (1947): 19-43.

Thurman, Melburn D. "Delaware Social Organization.” In Herbert C. Kraft, ed. A Delaware Indian Symposium. Harrisburg: The Pennsylvania Historical and Museum Commission, 1974.

Wallace, Anthony F. C. "Women, Land, and Society: Three Aspects of Aboriginal Delaware Life.” Pennsylvania Archaeologist 17 (1947): 1-35.

. "New Religions Among the Delaware Indians, 1600-1900." Southwestern Journal of Anthropology 12 (Spring 1956): 1-17.

. "Political Organization and Land Tenure Among the Northeastern Indians, 1600-1830." Southwestern Journal of Anthropology 13 (1957): 301-321.

Wellenreuther, Hermann. "White Eyes and the Delawares' Vision of an Indian State." Pennsylvania History: A Journal of Mid-Atlantic Studies 68 (Spring 2001): 201-205.

Weslager, C.A. “More About the Unalachtigo.” Pennsylvania Archaeologist 44 (Sept. 1975): $40-44$.

Winger, Otho. "The Indians Who Opposed Harmar." The Ohio State Archaeological and Historical Quarterly 50 (1941): 55-59. 
Young, Henry J. “A Note on Scalp Bounties in Pennsylvania." Pennsylvania History, Quarterly Journal of the Pennsylvania Historical Association 24 (Jan.-Oct. 1956): 204-210.

\section{BIBLIOGRAPHY}

\section{Unpublished Secondary}

Brown, Malcolm. “'Is it Not Our Land?': An Ethnohistory of the Susquehanna-Ohio Indian Alliance, 1701-1754." Ph. D. diss., Oklahoma State University, 1996.

Bureau of Indian Affairs Website. Available from http://www.doi.gov; INTERNET.

Carter, Michael Darryl. "Nationbuilding and the Military: The Life and Career of Secretary of War Henry Knox, 1750-1806.” Ph. D. diss., West Virginia University, 1997.

De Varo Jr. Lawrence J. "Pennsylvania’s Indian Policy With the Delawares, 1682-1742.” Master's thesis, Duquesne University, 1966.

McConnell, Michael N. "The Search For Security: Indian-English Relations in the TransAppalachian Region.” Ph. D. diss., The College of William and Mary, 1983.

McCullough, Frederick M. "The Efforts of Pennsylvania to Extend Her Influence Over the Indian Tribes in the Western Region of the Province, 1748-1758." Master's thesis, Duquesne University, 1964.

Merrell, James H. Personal Correspondence. July 31, 2003.

Radloff, Ralph Mark. "Moravian Mission Methods Among the Indians of Ohio.” Ph. D. diss., The University of Iowa, 1973.

Schutt, Amy C. "Forging Identities: Native Americans and Moravian Missionaries in Pennsylvania and Ohio, 1765-1782.” Ph. D. diss., Indiana University, 1995.

The Stockbridge Munsee Tribe of Mohican Indians Website. Available from homepage/mohican. INTERNET.

Sultzman, Lee. Website for the Delaware Tribe of Oklahoma. Available from lenape@cowboy.net. INTERNET.

Theis, Ruth Kathryn. "The Attitudes of the White People Toward the Indians of the Upper Ohio Valley, 1749-1795.” Master's thesis, University of Pittsburgh, 1935.

Thurman, Melburn D. "The Delaware Indians: A Study in Ethnohistory.” Ph. D. diss., University of California at Santa Barbara, 1973. 
Whritenour, Raymond. Correspondence with James Rementer. November 17, 1996. 